\title{
A TRIBO PISONIEAE MEISNER (NYCTAGINACEAE) NO BRASIL ${ }^{1}$
}

\author{
ANTONIO FURLAN ${ }^{*} \&$ ANA MARIA GIULIETTI**
}

\author{
*Departamento de Botânica, Instituto de Biociências, Universidade Estadual Paulista, Av. 24A, 1515, \\ Bela Vista, 13506-900 - Rio Claro, SP, Brasil. \\ **Programa de Pós-Graduação em Botânica, Departamento de Biologia, Universidade Estadual de Feira de \\ Santana, Av. Transnordestina s.n., Novo Horizonte, 44036-900 - Feira de Santana, Bahia, Brasil.
}

\begin{abstract}
The tribe Pisonieae Meisner (Nyctaginaceae) in Brazil]. A taxonomic revision of the Brazilian species of the tribe Pisonieae (Nyctaginaceae) is presented. Traditional methods, especially the analysis of more than 3000 specimens preserved in Brazilian and foreign herbaria complemented by specimens collected by the author and field observations, were employed in this study. Most species of the tribe Pisonieae occur in the Neotropics, except the genus Pisonia which presents a pantropical distribution. All Brazilian species are dioecious. Comparative studies of floral morphology showing generic distinctions in staminated, pistillated and frutiferous plants, are presented. On the basis of floral discontinuities the gênero Guapira and Neea are considered distinct, in opposition to Heimerl's systematic treatment presented in 1934. 30 species from Brazil are recognized and included in the genera Guapira, Neea and Pisonia: Guapira areolata (Heimerl) Lundell, G. campestris (Netto) Lundell, G. graciliflora (Mart. ex J.A.Schmidt) Lundell, G. hirsuta (Choisy) Lundell, G.laxa (Netto) Furlan, G. nitida (Mart. ex J.A.Schmidt) Lundell, G. noxia (Netto) Lundell, G. obtusata (Jacq.) Little, G. opposita (Vell.) Reitz, G. pernambucensis (Casar.) Lundell, G. venosa (Choisy) Lundell, Neea duckei (Huber) Furlan, N. floribunda Poepp. \& Endl., N. hermaphrodita S.Moore, N. hirsuta Poepp. \& Endl., N. laxa Poepp. \& Endl., N. macrophylla Poepp. \& Endl., N. madeirana Standl., N. obovata Spruce ex Heimerl, N. oppositifoha Ruiz \& Pav., N.ovalifolia Spruce ex J.A.Schmidt, N. parviflora Poepp. \& Endl., N. pendulina Heimerl, N. theifera Oerst., N. uleana (Heimerl) Furlan, N. verticillata Ruiz \& Pav., Pisonia aculeata L., P.ambigua Heimerl and $P$. zapallo Griseb. Identification keys to the genera and species, as well as descriptions, figures, distribution maps and a taxonomic discussion are presented for each studied taxon. The genus Guapira is limited to 12 species spread throughout the Central and Southeastem regions of Brazil while the genus Neea contains 15 species occurring mainly in Northeem region and the genus Pisonia with three species is centred in Southern Brazil. In the systematic treatment three new combinations are proposed, 56 names are considered as synonymies, whereas 15 names remained doubtful and 42 lectotypes are proposed.
\end{abstract}

Key words: Guapira, Neea, Pisonia, Torrubia, Caryophyllales.

RESUMO - [A tribo Pisonieae Meisner (Nyctaginaceae) no Brasil]. Nesta revisão taxonômica da tribo Pisonieae (Nyctaginaceae) no Brasil foram utilizadas as técnicas tradicionais em trabalhos taxonômicos, envolvendo a análise de cerca de 3000 espécimes depositados em herbários nacionais e estrangeiros, aliada a coletas e observações de campo. A maioria das espécies da tribo Pisonieae é neotropical, exceto o gênero Pisonia que apresenta distribuição pantropical. Todas as espécies brasileiras são dióicas. Um estudo de morfologia floral comparada mostra as diferenças genéricas em plantas estaminadas, pistiladas e com frutos. Pelas descontinuidades florais apresentadas, considerou-se os gêneros Guapira e Neea como distintos, em oposição ao tratamento sistemático de Heimerl publicado em 1934. São reconhecidas no país 30 espécies incluídas nos gêneros Guapira, Neea e Pisonia: Guapira areolata (Heimerl) Lundell, G. campestris (Netto) Lundell, G. graciliflora (Mart. ex J.A.Schmidt) Lundell, G. hirsuta (Choisy) Lundell, G. laxa (Netto) Furlan, G. nitida (Mart. ex J.A.Schmidt) Lundell, G. noxia (Netto) Lundell, G. obtusata (Jacq.) Little, G. opposita (Vell.) Reitz, G. pernambucensis (Casar.) Lundell, G. venosa (Choisy) Lundell, Neea duckei (Huber) Furlan, N. floribunda Poepp. \& Endl., N. hermaphrodita S.Moore, N. hirsuta Poepp. \& Endl., N. laxa Poepp. \& Endl., N. macrophylla Poepp. \& Endl., N. madeirana Standl., N. obovata Spruce ex Heimerl, N. oppositifolia Ruiz \& Pav., N. ovalifolia Spruce ex J.A.Schmidt, N.parviflora Poepp. \& Endl., $N$. pendulina Heimerl, $N$. theifera Oerst., $N$. uleana (Heimerl) Furlan, N. verticillata Ruiz \& Pav., Pisonia aculeata L., P. ambigua Heimerl e P. zapallo Griseb. São apresentadas chaves de identificação para os gêneros e espécies, bem como descrições, ilustrações, mapas de distribuição e comentários taxonômicos para os táxons estudados. Guapira foi delimitado com 12 espécies distribuídas principalmente na região Sudeste do Brasil, enquanto Neea inclui 15 espécies com ocorrência predominante na região Norte do Brasil e em Pisonia foram definidas três espécies concentradas na região Sul do pais. Neste trabalho foram propostas três combinações novas e 56 nomes foram reduzidos a sinonímia, permanecendo 15 nomes como duvidosos e 42 lectótipos são propostos.

Palavras-chave: Guapira, Neea, Pisonia, Torrubia, Caryophyllales.

\footnotetext{
${ }^{1}$ Parte da tese de doutorado do primeiro autor. Artigo compilado após o falecimento deste.
} 


\section{Introdução}

Tradicionalmente a família Nyctaginaceae esteve incluída na ordem Centrospermae junto com várias outras famílias de ovário súpero (Heimerl 1934, Eckardt 1964). Posteriormente foi incluída na ordem Caryophyllales (Cronquist 1968, 1981, 1988), onde permanece atualmente com mais 33 outras famílias (APG III 2009). Nyctaginaceae é caracterizada pela presença do antocarpo, que se forma pelo espessamento da parte basal das sépalas unidas, encerrando o fruto verdadeiro que normalmente é membranáceo. Rodman (1990) cita o antocarpo como autapomorfia sustentando o monofiletismo da família.

Nyctaginaceae inclui cerca de 30 gêneros com 300-400 espécies distribuídas principalmente nas regiões tropicais e subtropicais do Novo Mundo (Bogle 1964, Bittrich \& Kühn 1993). Algumas espécies são amplamente cultivadas como ornamentais (e.g. Bougainvillea), outras são naturalizadas ou ruderais como Mirabilis jalapa L. e várias espécies de Boerhavia.

A classificação de Nyctaginaceae a nível mundial utilizada até os anos 80 foi a de Heimerl (1934) que a dividia em cinco tribos: Boldoeae, Mirabileae, Colignonieae, Pisonieae e Leucastereae. Bittrich \& Kühn (1993) apresentaram uma classificação de Nyctaginaceae muito semelhante à de Heimerl (1934). Porém Douglas \& Spellenberg (2010), apoiados por uma filogenia baseada em dados moleculares (Douglas \& Manos 2007), reconheceram os seguintes grupos monofiléticos bem sustentados: Bouganvilleeae, Caribeeae, Colignonieae, Leucastereae, Nyctagineae e Pisonieae. Deve-se ressaltar que esta filogenia não incluiu amostras de seis gêneros de Nyctaginaceae.

Dessas tribos, Pisonieae é uma das maiores, com cerca de 120-200 espécies, com distribuição ampla, incluindo a região do Pacífico e a região Neotropical, sendo bem representada no Brasil. Morfologicamente Pisonieae é caracterizada por plantas lenhosas, geralmente dioicas, com flores destituídas de invólucro de brácteas e com embrião reto de cotilédones enrolados lateralmente (Heimerl 1934, Bittrich \& Kühn 1993).

Pisonieae tem muitas espécies no Brasil, nos gêneros Pisonia L., Guapira Aubl. e Neea Ruiz \& Pav., cuja delimitação é muito controvertida (Bogle 1974). Além disso, analisando os trabalhos sobre a família, chama a atenção a quase inexistência de chaves de identificação para as espécies da tribo Pisonieae. Choisy (1849) separou as espécies apenas em base geográfica, e as incluiu nas Américas, África, Austrália e Pacífico. Schmidt (1872) na "Flora Brasiliensis" separou as 25 espécies de Pisonia "sensu lato" em três grupos, utilizando como caracteres diferenciais a pilosidade e ápices das folhas. Heimerl, entre 1891 e 1934, publicou 18 trabalhos para a família, sem apresentar chaves de identificação para as espécies. Standley, entre 1909 e 1943, publicou 17 trabalhos na família, principalmente tratando das espécies norteamericanas; vários desses trabalhos apresentam chaves de identificação, porém apenas dois contêm referências a algumas espécies que ocorrem também no Brasil. No primeiro, sobre as Nyctaginaceae do noroeste da América do Sul, Standley (1931b) incluiu várias espécies de Torrubia sendo citada para o Brasil apenas T. olfersiana; no segundo, referente à Flora do Peru, Standley (1937a) incluiu três espécies de Neea presentes também na Amazônia brasileira. Reitz (1970) apresentou as Nyctaginaceae do sul do Brasil, com chave de identificação para as espécies. Gentry (1993) chegou a comentar que, ao nível de espécie, Nyctaginaceae é uma das mais difíceis famílias neotropicais. Assim, o processo de identificação de espécimes de Nyctaginaceae, especialmente provenientes do Brasil, tem sido difícil, demorado e incerto. Sá (2010) listou as espécies de Nyctaginaceae registradas no Brasil e encontrou em Pisoniae, 11 espécies de Guapira, 21 espécies de Neea e três espécies de Pisonia.

A ocorrência de vários problemas taxonômicos e a falta de especialistas em Nyctaginaceae, tanto ao nível nacional como internacional, motivaram a execução desse estudo de revisão dos gêneros da tribo Pisonieae no Brasil, que pretende atingir os seguintes objetivos: a. reavaliar a definição dos gêneros da tribo, em função das espécies brasileiras; b. fornecer meios de identificação dos gêneros e espécies da tribo no Brasil; c. revisar a taxonomia das espécies brasileiras do grupo, esclarecendo os limites morfológicos das mesmas e buscando encontrar caracteres morfológicos adicionais para diferenciar os gêneros da tribo, além dos já citados em literatura.

\section{Material e métodos}

Esse estudo baseia-se na análise de mais de 3000 exsicatas de coleções da maioria dos herbários brasileiros e de sete estrangeiros (acrônimos segundo Thiers continuously updated): ALCB, BHCB, BM, BR, CEN, CEPEC, CESJ, CGMS, CPAP, CVRD, EAC, ESA, ESAL, FCAB, FUEL, G, GUA, HB, HRB, HRCB, HUEFS, HUFU, HXBH, IAC, IBGE, ICN, IPA, ISA, JPB, K, M, MBM, MBML, MG, MO, OUPR, P, PACA, PEL, PEUFR, PMG, R, RB, RBR, SP, SPF, SPSF, TEPB, UB, UEC, UPG, UPCB, VIC, VIES.

$A$ identificação foi feita utilizando-se para comparação as descrições, ilustrações e os materiaistipo. A delimitação das espécies foi baseada principalmente na análise morfológica dos exemplares herborizados e do conhecimento destas espécies no campo, levando-se em conta as notáveis diferenças entre folhas novas e folhas adultas e também a deciduidade dos tricomas. A terminologia morfológica seguiu Radford et al. (1976), sendo a nervação foliar descrita segundo Hickey (1973). Foi utilizado o conceito morfológico ou clássico de espécie (Stuessy 1990), que considera as descontinuidades como elementos delimitadores.

Praticamente todos os nomes de espécies e ou variedades foram tipificados, seguindo as regras e recomendações do Código Internacional de Nomenclatura Botânica (Greuter et al. 1994). As 
lectotipificações seguiram ou uma clara intenção do autor em relação aos materiais citados, ou o exame dos síntipos e o melhor enquadramento segundo o protólogo, especialmente por se trataram geralmente de plantas dióicas.

Os desenhos foram feitos com base nos materiais mencionados, dando-se preferência aos materiais-tipo; os detalhes morfológicos foram feitos utilizando câmara clara acoplada a microscópio estereoscópico. Os estigmas penicelados das espécies de Guapira tendem a se aglutinar um pouco, tanto em materiais fixados quanto em materiais de herbário; normalmente os estigmas foram desenhados da forma como foram encontrados nestes materiais, mas deve-se entender que na antese apresentam-se bem distendidos.

Foram feitas expedições de coleta aos cerrados e campos rupestres dos Estados de Minas Gerais, Bahia e Goiás, às matas do litoral da Bahia e aos cerrados e Mata Atlântica do Estado de São Paulo. Os locais de ocorrência das espécies foram plotados no "Base map $n^{\circ} 1$ " da Organização Flora Neotropica preparado por H.R.Rypkema e publicado por State University of Utrecht, Holanda, 1979. Estes mapas foram ligeiramente modificados com a introdução de novos estados e capitais dos territórios.

Em cada espécie, estão citados todos os materiais examinados quando estes são limitados; nos casos de material vultoso, apresentada-se uma relação de material selecionado, apenas um ou dois espécimes por estado do país. Por outro lado, a Lista de Exsicatas no final do trabalho é completa, e segue ordem alfabética de sobrenomes do primeiro coletor, associado ao número que cada espécie recebeu no texto. Nessa lista e também na citação do material examinado, foram usadas as abreviações: CFCR: Coleção da Flora dos Campos Rupestres; CFSC: Coleção da Flora da Serra do Cipó; CGGSP: Comissão Geográfica e Geológica de São Paulo; CLTEMGA: Comissão de Linhas Telegráficas e Estratégicas do Mato-Grosso ao Amazonas; FEEP: Flora da Estação Ecológica do Panga; GPC: Grupo "Pedra do Cavalo"; HAMP: Herbário Amazônico do Museu do Pará.

\section{Breve histórico e taxonomia de Nyctaginaceae e Pisonieae}

$\mathrm{Na}$ primeira revisão mundial da família Nyctaginaceae, Choisy (1849) distinguiu três tribos, baseadas na morfologia do invólucro calicíneo: tribo Mirabileae com seis gêneros, tribo Bougainvilleae com dois e tribo Boerhaavieae com oito. Essa classificação foi seguida por Schmidt (1872) na monografia da Flora Brasiliensis.

Bentham \& Hooker (1880) também reconheceram três tribos, porém dando ênfase nos caracteres do fruto e do embrião: tribos Pisonieae, Leucastereae e Mirabilieae, esta última subdividida em quatro subtribos: Boerhaavieae, Bougainvilaeeae, Abronieae e Boldoeae.
Fiedler (1910) dividiu Nyctaginaceae em quatro subfamílias: Mirabiloideae, Boldoideae, Pisonioideae e Leucasteroideae. Já Heimerl (1934) considerou cinco tribos: Mirabileae, Colignonieae, Boldoeae, Pisonieae e Leucastereae, classificação que foi adotada por Eckardt (1964) no "Syllabus der Pflanzenfamilien".

A tribo Pisonieae foi estabelecida por Meisner (1841), incluindo os gêneros Pisonia L., Neea Ruiz \& Pav., Salpianthus Humb. \& Bonpl. e Reichenbachia Sprengel, os dois úlimos posteriormente dispersos em outras tribos. Choisy (1849) não utilizou a proposta de Meisner (1841) e deu ênfase apenas ao invólucro floral incluindo desta forma os gêneros Pisonia e Neea, entre outros, na tribo Boerhavieae que possui invólucro nulo ou apenas com bractéolas. Bentham \& Hooker (1880) foram os primeiros a reconhecer e usar a estrutura do embrião como caráter para reorganizar - grupo e caracterizaram a tribo Pisonieae pela presença de embrião reto. Segundo os autores a tribo seria formada pelos gêneros Pisonia, Neea, Cephalotomandra H.Karst. \& Triana e Timerova Montrouz. Este último gênero no trabalho de Heimerl (1934) foi incluído como uma seção de Calpidia Thouars. Fiedler (1910) acrescentou dados palinológicos aos dados morfológicos já utilizados para caracterizar o grupo e propôs a elevação da tribo Pisonieae a subfamília Pisonioideae devido ao pólen colpado.

Heimerl (1934) incluiu seis gêneros em Pisonieae, que foi definida pela presença de embrião reto com os cotilédones enrolando-se lateralmente e por serem plantas lenhosas, geralmente dióicas, sendo a ocorrência de flores monoclinas restrita ao gênero Pisoniella Standley. Bittrich \& Kühn (1993) mantiveram essa mesma definição da tribo, acrescentando outros caracteres como a ausência de invólucro de brácteas, a presença de antocarpo e o pólen tricolpado a pantocolpado. Nesta classificação, Pisonieae é composta por seis gêneros: Pisonia, Guapira, Neea, Cephalotomandra já citados anteriormente, e ainda Neeopsis Lundell e Grajalesia Miranda.

O reconhecimento e circunscrição de Pisonia, Guapira e Neea tem passado por grande controvérsia. Pisonia nem sempre tem sido aceito com a conceituação atual por possuir dois tipos de antocarpos (diclésios e acrossarcos, segundo Spjut 1994). Britton (1904) separou Pisonia "sensu latu" em Pisonia "sensu strictu" com antocarpos glandulosos, e Torrubia Vell. com antocarpos carnosos e sem glândulas. Heimerl (1934) manteve Pisonia "sensu latu" considerando esses dois grupos de plantas ao nível de seções. Woodson Jr. \& Kidd (1961) tornaram a reconhecer os mesmos dois grupos como gêneros diferentes, porém com os nomes de Pisonia L. e Guapira Aubl. Bogle (1974) não aceitou o gênero Guapira mas o mesmo foi aceito por Dumas (1990). Burger (1983) comentou que as espécies de Neea poderiam ser transferidas para Guapira.

$\mathrm{Na}$ filogenia apresentada por Douglas \& Spellenber (2010), a tribo Pisonieae é bem sustentada pelos dados moleculares, incluindo quatro gêneros: 
Guapira, Neea, Pisonia e Pisoniella. Esse último gênero já havia sido incluído nesta tribo por Bentham \& Hooker (1880) e Heimerl (1934), mas Bittruich \& Kühn (1993) haviam transferido o mesmo para a tribo Nyctagineae. A topologia apresentada mostra Pisoniella como grupo-irmão de um clado formado por sete terminais de Pisonia, Neea e Guapira, com indicação de que os dois últimos possam não ser monofiléticos (Douglas \& Manos 2007).

Pisoniella diferencia-se dos demais gêneros da tribo por possuir flores monoclinas com estigma peltado, saliente e visível em todas as flores, e antocarpo glanduloso. Ocorre no México e em regiões andinas da Bolívia e Argentina. Além das características morfológicas já referidas para o gênero, ocorre também a presença de inflorescências em umbelas simples, que não está presente nos demais gêneros da tribo. Lisboa (1974) descreveu uma nova espécie neste gênero, proveniente da região de Ouro Preto, Minas Gerais, porém o estudo dos materiais citados por este autor mostraram a presença de flores diclinas, sendo a espécie transferida para Guapira.

Pisonia L. e Neea Ruiz et Pav. apresentam um número relativamente reduzido de estames e estaminódios, entre cinco a 13. O gênero Pisonia com distribuição pantropical, é caracterizado pelas flores estaminadas com perianto campanulado a afunilado com estames salientes, e flores pistiladas com estigma penicelado saliente. Diferentemente, as espécies de Neea são exclusivamente neotropicais e apresentam flores estaminadas globosas, urceoladas ou fusiformes com estames inclusos, e flores pistiladas com estigmas papilosos ou curto-penicelados.

Heimerl (1934) subdividiu Pisonia em duas seções: Pisonia sect. Glanduliferae Heimerl, com antocarpos glandulosos, onde foram sinonimizados os gêneros Guapira Aubl., Gynasirum Neck., Torrubia Vell., Bessera Veil., Columella Vel., e Torrulia Steud. e $P$. sect. Eupisonia Heimerl, com antocarpos carnosos, onde foi sinonimizado o gênero Pallavia Vell.

Britton (1904) e Standley (1911, 1916, 1918, 1922, 1931a, 1931b, 1936, 1937a, 1937c, 1937d, 1939 e 1940) incluíram em Torrubia as espécies com antocarpos carnosos. Diferentemente, Woodson Jr. \& Kidd (1961) incluíram as espécies com essa característica em Guapira. Little Jr. (1964) propôs a conservação do nome Torrubia contra Guapira, mas o Comitê Internacional de Nomenclatura rejeitou a proposta (Mc Vaugh 1968). Como consequência, Little Jr. (1968) e Lundell (1968), fizeram as novas combinações em Guapira.

$O$ presente trabalho reconhece os gêneros Guapira e Neea, estando os principais caracteres diferenciais nas inflorescências, flores e frutos. Reitz (1970) considerou a presença ou ausência de estaminódios como um caráter distintivo entre os gêneros, porém não pode ser mantido na separação dos gêneros. Também, Barroso (1978) utilizou o caráter disposição das bractéolas logo abaixo do cálice ou ao longo do ramo final, como distintivo para os gêneros, porém, o mesmo é válido apenas para os exemplares em fruto. As evidências moleculares de que possívelmente Neea e Guapira não constituam grupos monofiléticos (Douglas \& Manos 2007) são aqui consideradas ainda insuficientes devido ao pequeno número de terminais estudados: duas amostras identificadas como Guapira e duas como Neea.

\section{Morfologia geral, distribuição e usos de Pisonieae}

Todas as espécies brasileiras pertencentes à tribo Pisonieae são lenhosas, com flores normalmente diclinas e embrião reto com os cotilédones enrolados lateralmente entre si, sendo este o caráter diagnóstico da tribo. As demais tribos de Nyctaginaceae possuem embrião recurvado ou anelado (Woodcok 1928, Bogle 1974, Heimerl 1934).

Hábito e ramificação - As Pisonieae são arvoretas ou árvores, mas ocasionalmente podem ser classificadas como arbustivas devido a presença de ramificação do caule próximo da base, ou mais raramente escandentes como ocorre em indivíduos de Guapira pernambucensis, que também pode ter porte arbustivo e ereto, e em Pisonia aculeata que normalmente apresenta os ramos divergindo em ângulo reto ou até retronásticos. Em Neea, apenas $N$. duckei e $N$. uleana parecem ser escandentes, pela presença de ramos alongados com predominância de um dos ramos em cada ramificação. As espécies escandentes em Pisonieae tem 0 lenho com predominância de parênquima, mas outras modificações na anatomia do caule podem aparecer, como variações cambiais, geralmente produzindo floema incluso, em espécies de Neea, Pisonia e Rockia (Record \& Hess 1943, Metcalfe \& Chalk 1988).

Em quase todas as espécies de Pisonieae estudadas ocorre um padrão de ramificação característico, onde os ramos se ramificam dicotomicamente a cada dois nós, tendo sido esse padrão já referido anteriormente por Heimerl (1934). Tanto em espécimes vivos como herborizados, observa-se logo acima de uma dicotomia, a formação de um nó com duas folhas opostas ou subopostas, e normalmente com gemas que nunca se desenvolvem vegetativamente, mas às vezes formam inflorescências. (Fig.1A). O nó logo acima deste possui em geral quatro folhas dispostas verticiladamente e quase sempre diferentes entre si (anisofilia). Este segundo nó em geral se ramifica dicotomicamente, e este padrão de ramificação repete-se sucessivamente, formado um conjunto com organização divaricada muito peculiar. Este é um bom caráter que auxilia o reconhecimento de plantas estéreis de Pisonieae, apesar de não ter grande utilidade na distinção dos gêneros ou das espécies.

Em Guapira tomentosa e G. laxa os ramos novos algumas vezes podem apresentar um crescimento mais ou menos indeterminado com ramificações tricotômicas. Em G. pernambucensis, principalmente nos indivíduos com hábito escandente, um dos ramos da dicotomia costuma ser bem mais 
longo e mais robusto, enquanto o ramo menor geralmente não repete o padrão. Em Pisonia aculeata e $P$. zapallo (não observadas na natureza durante 0 desenvolvimento desse trabalho), tal padrão de ramificação não foi observado nas exsicatas examinadas. Provavelmente tal situação ocorre porque em $P$. aculeata os ramos frequentemente se transformam em espinhos, e em $P$. zapallo a florada ocorre em indivíduos sem folhas ou apenas com folhas novas. Nas espécies de Neea com folhas muito grandes esse padrão de ramificação é mais difícil de ser observado em exsicatas, pois geralmente são coletados apenas as extremidades dos ramos. Porém, nas espécies com folhas menores o padrão geral é facilmente observável.

A ocorrência de várias gemas acessórias supra-axilares (acima da cicatriz foliar) foi observada em Guapira venosa e em Neea obovata. Na primeira espécie é provável que estas gemas acessórias estejam relacionadas com a caulifloria.

Folhas - As espécies de Pisonieae geralmente apresentam folhas ligeiramente suculentas que se tornam enegrecidas durante 0 processo da herborização. Também é visível em folhas novas ou membranáceas, a ocorrência de minúsculos pontos alongados e claros, que são indicadores da presença de idioblastos portadores de ráfides (Metcalfe \& Chalk 1950). Apesar desses mesmos autores destacarem a presença de ráfides e estilóides em folhas de Pisonia nitida e em espécies de Neea (Metcalfe \& Chalk 1988), verifica-se que a presença de células portadoras de ráfides, ocorre em outros orgaõs das plantas, sendo que nas flores e antocarpos geralmente se concentram na base do anel estaminodial, podendo ser considerado como uma característica de Nyctaginaceae.

Em Pisoniae muitas espécies apresentam na epiderme foliar tricomas pluricelulares e unisseriados, que podem ser ramificados ou não. Metcalfe \& Chalk (1950) ilustram o tricoma ramificado de Pisonia tomentosa Casar. (=Guapira noxia) com a célula terminal muito alongada. Em Guapira noxia, G. graciliflora e em G.laxa, e em Neea madeirana, $N$. ovalifolia e $N$. obovata foram observados tricomas com células terminais alongadas e com conteúdo frequentemente ferrugíneo-avermelhado. Devido à deciduidade dos tricomas nessas espécies, o caráter ainda não foi devidamente explorado.

Todas as espécies estudadas mostram o tipo de nervação broquidódromo. Em Neea obovata e $N$. ovalifolia as folhas adultas apresentam as nervuras secundárias (ou primárias laterais segundo Hickey 1973) bem próximas entre si e mais ou menos paralelas, correndo até quase a margem.

A anisofilia nos pares ou nos verticilos de folhas ocorre em quase todas as espécies estudadas, apesar de não haver um padrão constante para cada espécie, e as vezes ser pouco pronunciado, como observado em Neea theifera e Guapira noxia duas espécies de cerrado.

Nas espécies de Pisoniae as folhas apresentam a base ligeiramente inequilátera, podendo ser bastante assimétrica em Neea macrophylla.

Apesar da ocorrência de estrutura Kranz haver sido por Metcalfe \& Chalk (1988) para vários gêneros de outras tribos de Nyctaginaceae, não foi reportada ainda para qualquer espécie da tribo Pisonieae. Tal situação poderia estar relacionada com o hábito arbóreo?

Dioicia - Na tribo Pisonieae cinco gêneros tem flores diclinas em plantas dióicas ou subdioicas e apenas Pisoniella apresenta flores monoclinas. Apesar das espécies do Brasil terem flores díclinas, muitas vezes esse caráter não é de fácil observação, pois nas flores estaminadas o pistilódio pode ter a aparência de um gineceu normal, por portar um óvulo no seu interior. Porém, o estilete é curto e o estigma não é desenvolvido. O óvulo apesar de poder apresentar o mesmo tamanho do óvulo encerrado no gineceu da flor pistilada, não é funcional. Nas populações de Guapira opposita que vivem em áreas de dunas, foi observado que esporadicamente as plantas podem apresentar ramos com inflorescências estaminadas e ramos com restos de infrutescência do período reprodutivo anterior. Em Guapira campestris foi observado um indivíduo com uma flor pistilada no mesmo aglomerado de flores estaminadas. Tais ocorrências apesar de esporádicas, indicam que as plantas em Pisoniae podem sofrer alteração de sexo no decorrer de sua existência ou apresentar também plantas monoicas.

Inflorescências - Bogle (1974) caracterizou as inflorescências de Pisonieae como cimeiras corimbosas, pedunculadas, umbeliformes a tirsiformes. Foi observado em todas as espécies que as inflorescências são terminais e se caracterizam pela ausência de um eixo principal homogêneo dominando os ramos laterais, podendo ser incluído como um cimóide na definição de Weberling (1989) (Fig.1B-O). Porém, enquanto pela definição os cimóides apresentam o eixo principal terminando em uma flor, nas espécies estudadas, apenas os ramos laterais possuem uma flor terminal. Provavelmente tal situação seja resultado de aborto da flor terminal, como ocorre, por exemplo, em algumas Myrtaceae (Weberling 1988). O tipo de ramificação dicasial predominante nas inflorescências de Pisonieae poderia ser explicado também, pelo aborto das demais flores terminais dos eixos das inflorescências parciais cimosas, exceto nos ramos distais que sempre possuem a flor terminal (Fig.1B).

O padrão de ramificação apresentado pelas inflorescências mostrou-se importante para distinguir grupos de espécies. Em todas as espécies de Neea, e na maioria das espécies dos outros gêneros estudados, as inflorescências apresentam o pedúnculo que pode se ramificar dicotomicamente (Fig. 1G, KL,O). Em várias espécies de Guapira, são produzidos vários ramos primários, dispostos verticiladamente, o que resulta em um aspecto umbeliforme (Fig. $1 \mathrm{H}-\mathrm{I}, \mathrm{M}$ ). Já a formação de ramos opostos e decussados é menos frequente (Fig.1F). Estes padrões no entanto, geralmente não se repetem nos ramos secundários. $A$ relativa constância deste caráter para diferentes 


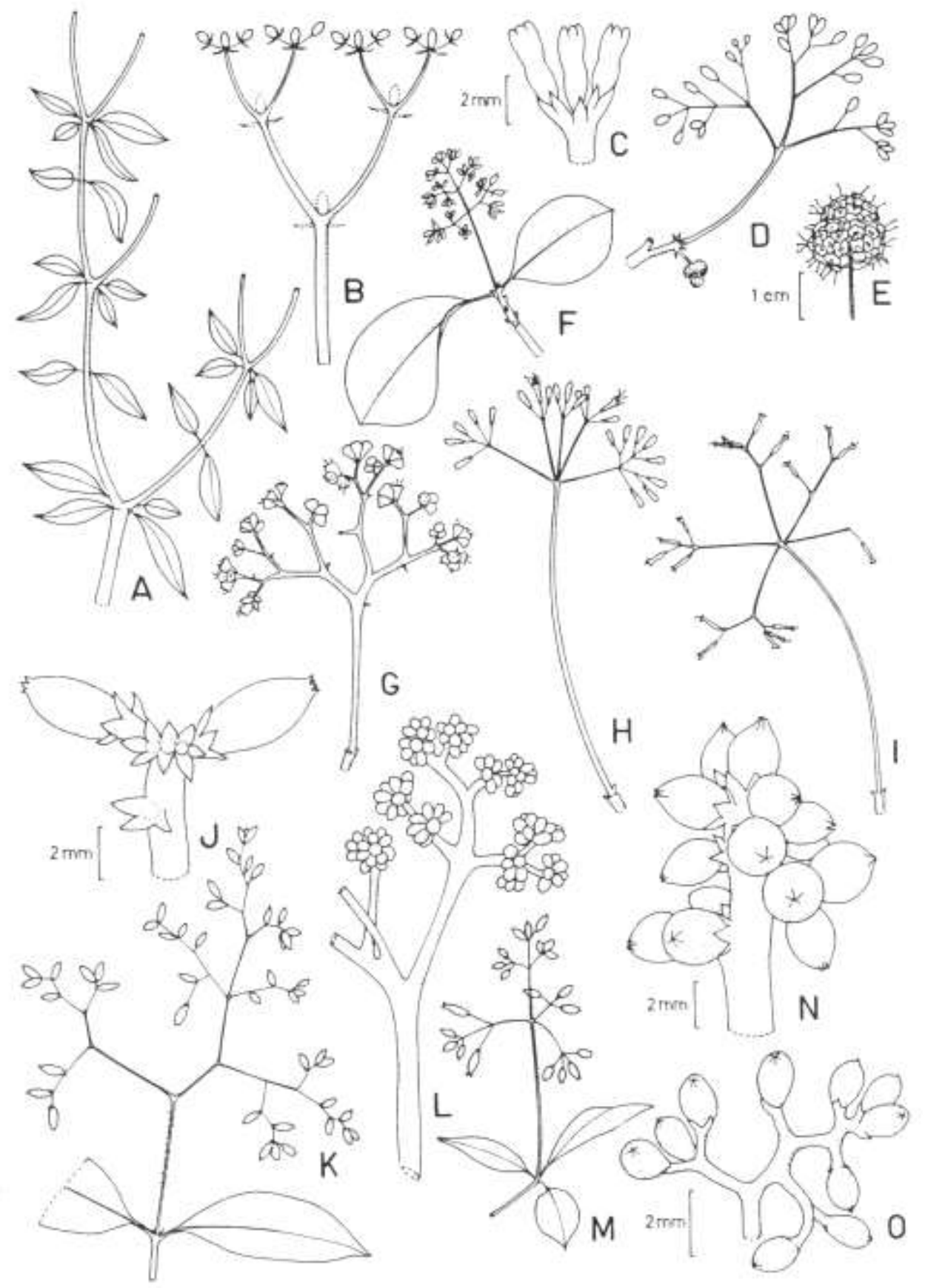

Fig. 1 - Hábito e inflorescências em Pisonieae: A. Esquema mostrando o tipo de ramificação predominante nas espécies da Tribo Pisonieae e a heterofilia dos pares ou verticilos de folhas. B. Diagrama parcial da inflorescência cimóide, com representação das Axes terminais e das abortadas. C. Címula pistilada jovem de Guapira nitida. D. Inflorescências estaminadas, adulta e jovem, de Pisonia ambigua. E. Inflorescência estaminada capituliforme aglomerada de $P$. aculeta. F. Inflorescência pistilada de G. graciliflora. G. Inflorescência estaminada de G. areolata. H, I. Inflorescência estaminada e inflorescência pistilada de G. opposita. J. Ramo terminal da inflorescência estaminada de Neea theifera, com címulas aglomeradas; flores deciduas mostrando a disposição das brácteas e bracteolas. K. Inflorescência estaminada de $N$. hermaphrodita. L. Ramo da inflorescência estaminada de N .floribunda. M. Inflorescência estaminada de $N$. pendulina. N. Ramo terminal da inflorescência estaminada de $N$. theifera. O. Ramos terminais da inflorescência estaminada de $N$. obovata. (C M.A. Assis et al. 309; D - N. Taroda et al. 6624; E - E. Hassler 8615; F - I. Cordeiro et al. CFCR 10111; G - E. Hassler 7813; H A.M. Carvalho et al. 653; I - J.L. Hage \& E.B. Santos 788; J e N - I. Cordeiro et al. CFSC 6643; K - A. Schinini 21483; L - L.A.M. Silva 1816; M - G. Hatschbach \& E. Moreira 6631; O - A. Ducke HAMP 12414). (Figs. D, F, G, H, I, K, L e M em tamanho natural). 
espécies de Guapira já havia sido referido por Heimerl (1912), e neste trabalho foi utilizado o padrão de ramificação para separar dois grupos de espécies no gênero.

Cada flor em Pisoniae apresenta na base duas bractéolas opostas (profilos $\alpha$ e $\beta$ segundo Weberling 1988), e uma bráctea normalmente muito semelhante as bractéolas (Fig.1J). Em geral essas três estruturas foliares estão praticamente no mesmo nível, indicando que o mesopódio não se desenvolveu. Entretanto, apenas nas espécies de Pisonia na fenofase de frutificação, o mesopódio se desenvolve bastante, ocasionando o distanciamento da bráctea e das bractéolas, que se tornam visivelmente alternas (Fig. $65 \mathrm{~L})$.

No gênero Neea, o tamanho da bráctea e das bractéolas é um caráter taxonômico importante, podendo ser praticamente inconspícuas em $N$. floribunda, ou evidentes e alongadas em $N$. pendulina, $N$. parviflora, $N$. hirsuta e $N$. uleana, sendo que nessas duas últimas espécies, podem atingir o mesmo comprimento das flores.

Flores - A forma dos botões florais constitui um bom caráter na separação dos gêneros. Em Pisonia e Guapira os botões são clavados com ápice sempre truncado (Fig. 2A, C, E, G). Em Neea os botões são globosos ou cilíndricos, com ápice arredondado e as vezes apiculado (Fig. 2H-L). A prefloração em todas as espécies de Pisoniae é induplicado-valvar, com as bordas das peças florais um pouco incurvadas para o interior do botão. Em Pisonia e Guapira tal organização é de fácil observação pois as induplicacões são salientes (Fig. 2A, G). Em Neea porém, a prefloração pode parecer à primeira vista, do tipo valvar. Nas espécies com flores de indumento mais denso este caráter torna-se mais evidente principalmente no início da antese (Fig. 2K).

Nos três gêneros estudados de Pisonieae as flores são sempre sésseis, fato evidenciado pela presença da bráctea e das bractéolas na base das mesmas. Em descrições antigas, é mencionado a presença de "pedicelo", mas a estrutura referida corresponde aos ramos distais da inflorescência, ou aos ramos laterais das címulas ou cimeiras terminais, ou ainda a hipopódios. Em Guapira foi observado que muito raramente a flor central da címula desenvolve um curto pedicelo acima das bractéolas, com até 1 $\mathrm{mm}$ de comprimento. Mesmo no gênero Pisonia cujos ramos finais alongam-se bastante na frutificação distanciando a bráctea das bractéolas, observa-se que a última bractéola permanece na base do antocarpo epipódio muito reduzido na terminologia de Weberling (1989).

O termo perianto tem sido muito utilizado para se referir ao envoltório único e corolíneo em Nyctaginaceae (Helmerl 1934). Estudos de anatomia comparada para famílias de Caryophyllales indicam que o perianto é monoclamídeo, formado apenas pelo cálice gamossépalo, com 4-5 sépalas (Cronquist 1988).

Estão nas flores os principais caracteres para distinção dos gêneros em Pisoniae (Fig. 3,4).
As flores estaminadas de Pisonia possuem estames salientes e minúsculas glândulas alinhadas externamente no tubo do cálice, essas são bem visíveis na flores das plantas vivas e nas flores de espécimes herborizados quando rehidratadas (Fig. 3AB). Em Guapira os estames também são salientes mas não há glândulas no tubo do cálice (Fig. 3C, G). Em Neea, os estames são inclusos (Fig. 3K-N), e mesmo em $N$. obovata onde o tubo do cálice é bem curto e campanulado, as anteras são visíveis na mesma altura da fauce (Fig. $3 \mathrm{H}-\mathrm{I}$ ).

As flores pistiladas em Pisonia apresentam o tubo do cálice com glândulas e o estigma é penicelado e saliente do tubo do cálice. Podem apresentar estaminódios ou estes serem reduzidos a um anel na base do ovário (Figs. 4A-B). Em Guapira o tubo do cálice não apresenta glândulas e o estigma é penicelado-radiado (em forma de um pincel aberto com os ramos filiformes expandidos) e saliente do tubo do cálice. Os estaminódios são geralmente curtos, não atingindo o espessamento interno que se localiza na região mediana da flor ou chegando um pouco acima, e apresentam os rudimentos de antera foliáceos e da mesma coloração do filete (Fig. 4D-F). Em Neea o tubo do cálice não apresenta glândulas e o estigma é agudo, papiliforme a franjado, ou pouco lacerados, mas nunca penicelados radiadamente e incluso ou curtamente saliente no tubo do cálice (Fig. 4I, O-P). Os estaminódios são mais desenvolvidos, e geralmente ultrapassam o espessamento interno, que nas flores pistiladas de Neea localizam-se usualmente um pouco abaixo da região mediana e apresentam os rudimentos de antera pequenos e espessos, mas com a mesma forma da antera e coloração mais escura que os filetes. Na frutificação os estaminódios se alongam acompanhando o crescimento do ovário e do antocarpo, e frequentemente dentro da cúpula apical são encontrados os rudimentos de antera aderidos ao estilete logo abaixo do estigma,.

As flores estaminadas e pistiladas em Pisonia e Guapira, geralmente caracterizam os gêneros (Fig. $5 \mathrm{C}-\mathrm{F})$. Em Neea porém, as flores estaminadas são bem diversificadas e nesse trabalho foram utilizadas para separar grupos de espécies (Fig. 5A-B). Flores estaminadas urceoladas ou globosas com ápice bem constrito, ocorre no grupo formado por $N$. theifera, $N$. hemaphrodita, $N$. floribunda, $N$. madeirana e $N$. verticillata (Fig. $4 \mathrm{~J}-\mathrm{K}, \mathrm{M}$ ), enquanto flores tubulosas ou pouco urceoladas com o ápice não constrito ocorre no grupo formado por $N$. hirsuta, $N$. pendulina, $N$. ovalifolia, N. laxa, N. oppositifolia e N. macrophylla (Fig. 4L, N-O).

Fruto, semente e embrião - O fruto em Nyctaginaceae é definido como futo acessório por Bogle (1974). Para a maioria dos autores que lidam com a família, o fruto acessório de Nyctaginaceae recebe a denominação especial de antocarpo, definido por Spujt (1994) pelo fato do ovário após ser fecundado e desenvolvido ter outras partes florais que acompanham tal desenvolvimento. Utilizando as definições propostas por Spujt (1994), podemos encontrar dois tipos distintos de antocarpos em 


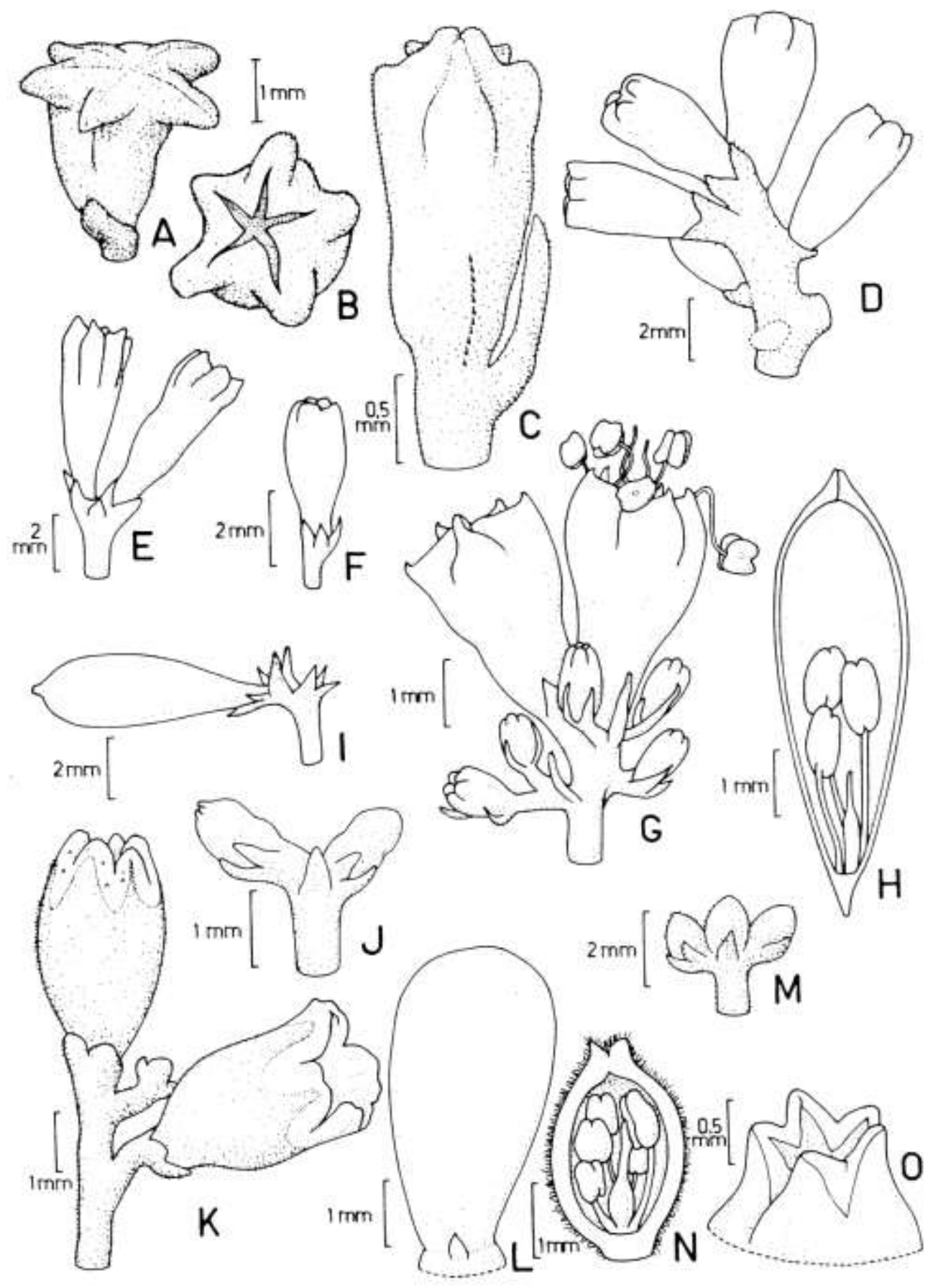

Fig. 2 - Botões e prefloração em Pisonieae: A. Pisonia aculeata, botão estaminado. B. P zapallo, botão estaminado. C. P.ambigua, botão pistilado. D. Guapira noxia, botões estaminados. E. G. nitida, botões estaminados. F. G. hirsuta, botão estaminado. G. G. graciliflora, botões estaminados com desenvolvimento gradual. $H$. Neea laxa, botão estaminado em corte longitudinal. I. N. laxa, botão estaminado. J. N. ovalifolia, botões pistilados. K. N. obovata, botões em início de antese. L. N. floribunda, botão estaminado. M. N. madeirana, botões estaminados. N. N. madeirana, botão estaminado em corte longitudinal. $O$. N. theifera, ápice da flor estaminada mostrando prefloração. (A - E. Hassler 8615; B - T. Rojas 295; C - J.R. Pirani e O. Yano 753; D - G.M. Araujo 32; E - M.A. Assis et al. 317; F - Reitz e Klein 5054; G - D.C. Zappi et al. CFCR 8367; H, I - M.C. Viana 76 $J$ - A. Ducke s.n. RB 4358; K - J.R. Pirani et al. 2580; L - L.A.M. Silva 1816; M, N - M.G. Silva 6092; O - I. Cordeiro et al. CFSC 6643). 


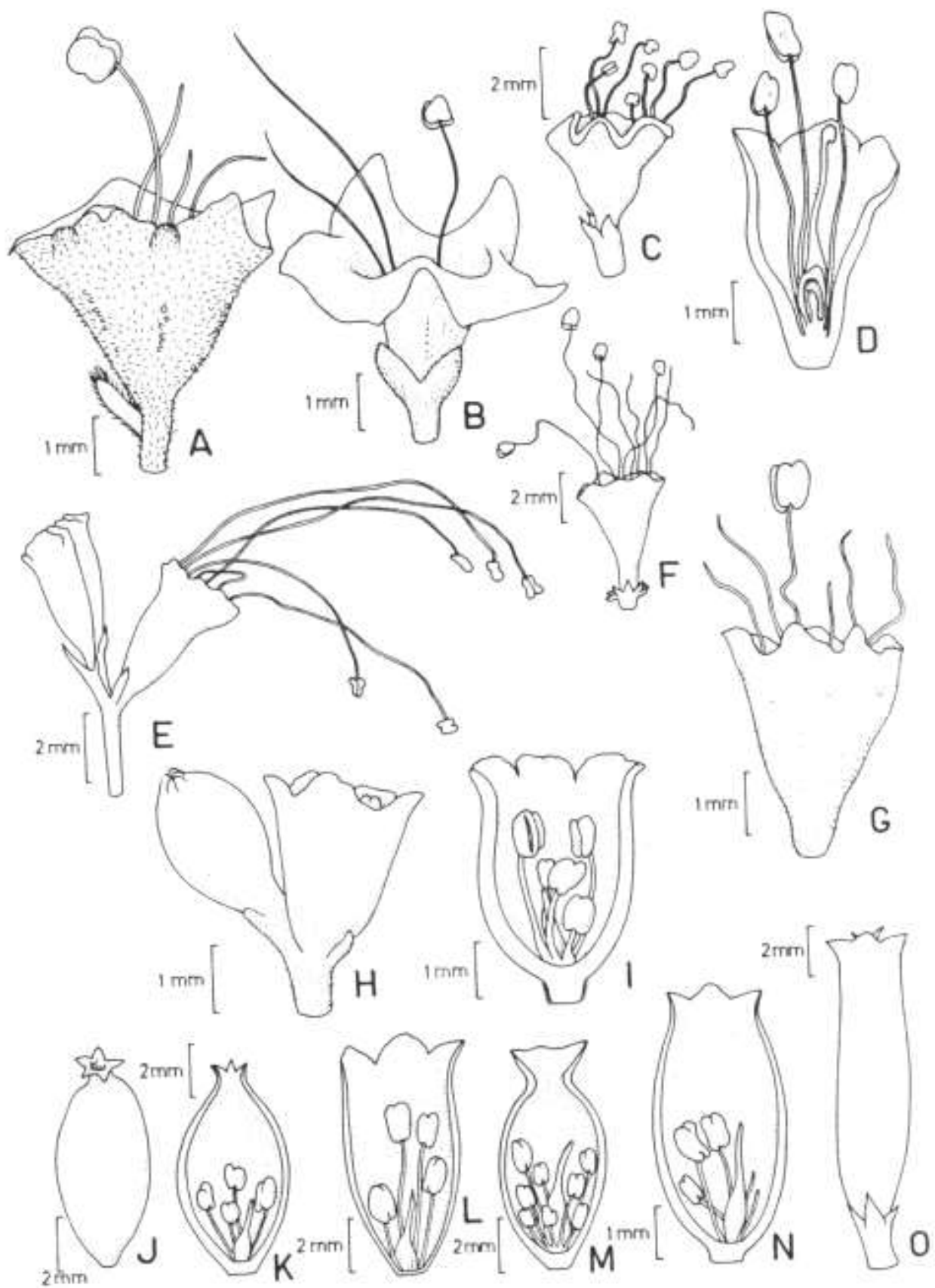

Fig. 3 - Flores estaminadas em Pisonieae: A. Pisonia ambigua, flor com glândulas. B. P. aculeata, flor com glândulas. C. Guapira obtusata. D. G. opposita, flor em corte longitudinal. E. G. opposita, botões e flor com estames longo-salientes. F. G. venosa. G. G. laxa. H. Neea obovata, botão e flor com anteras pouco visíveis. I. N. obovata, flor com tubo do cálice em corte longitudinal. J, K. N. theifera, flor e tubo do cálice em corte longitudinal. L. N. oppositifoha, tubo do cálice em corte longitudinal. M. N. madeirana, tubo do cálice em corte longitudinal. N. N. macrophylla, tubo do cálice em corte longitudinal. O. N. laxa. (A Chodat s.n.; B - E. Hassler 8615; C - A.M. Carvalho et al. 860; D - J.E.L.S. Ribeiro et al. 272; E - G. Hatschbach 46971; F - C.C. Berg 545; G - H. Zenaide 25; H - E. Pereira 1786-B; I - J.R. Pirani et al. 2580; J, K - I. Cordeiro et al. CFSC 6643; L - C.A. Cid e B.W. Nelson 2728; M - N.T. Silva 5401; N - J.A. Ratter et al. 4392; O - R.S. Pinheiro 1329). 


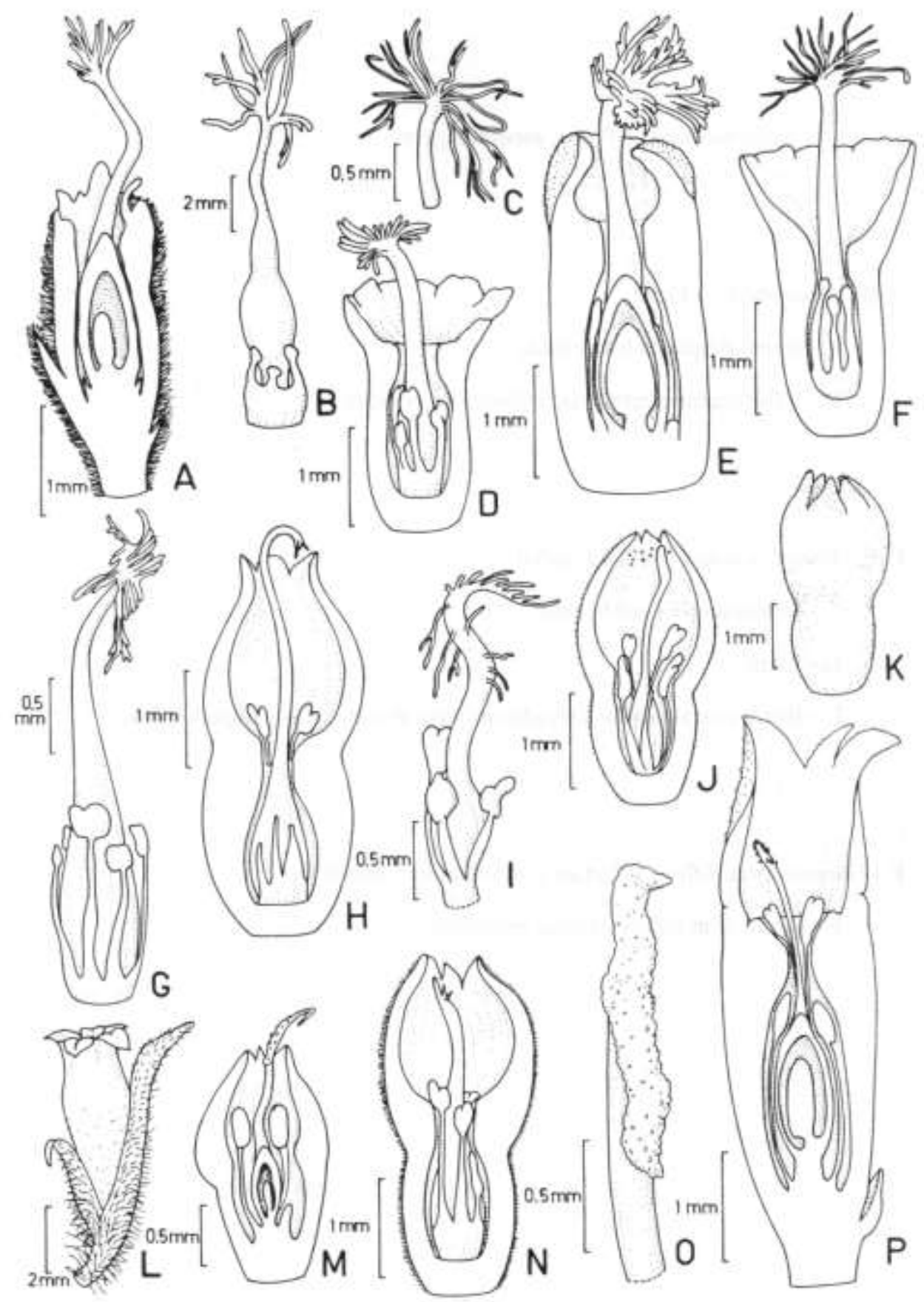

Fig. 4 - Flores pistiladas em Pisonieae: A. Pisonia aculeata, flor em corte longitudinal. B. P. ambigua, ovário com curto ginóforo e estaminódios. C. Guapira opposita, detalhe do estigma expandido. D. G. nitida, tubo do cálice em corte longitudinal. E. G. noxia, flor em corte longitudinal. F. G. opposita, tubo do cálice em corte longitudinal. G. G. nitida, ovário e estaminódios. H. Neea oppositifolia, tubo do cálice em corte longitudinal. I. N. macrophylla, ovário e estaminódios. J. N. obovata, tubo do cálice em corte longitudinal. K. N. ovalifolia. L. N. hirsuta, flor com bráctea e bractéola. M. N. hermaphrodita, tubo do cálice em corte longitudinal. N. N. ovalifolia, tubo do cálice em corte longitudinal. O. N. theifera, detalhe do estigma. P. N. laxa, flor em corte longitudinal. (A - E. Hassler 3165; B - T.S. Santos 3941; C, F - G.T. Prance 26369; D - P.L.R. Moraes 877; E - I. Schiavini 129; G - A. Furlan et al. 1216; H - A.S. Silva et al. AS-195; I - M. Pereira-Noronha 476; J - R.L. Fróes 24787; K, N - A. Ducke s.n. RB 4358; O - S.A. Mori 13682; M - W. Thomas et al. 4251; O - J.R. Pirani et al. CFSC 6675; P - J.A. Kallunki e J.R. Pirani 452). 
Pisoniae. Em Pisonia o antocarpo seria do tipo Diclésio onde o cálice ampliado, que se desenvolve circundando o fruto verdadeiro, é seco e indeiscente, enquanto os antocarpos em Guapira e Neea seriam do tipo Acrossarco, onde o cálice ampliado, que se desenvolve circundando o fruto verdadeiro, pouco diferenciado, é carnoso.

Em Pisonieae, a porção superior do tubo do cálice é persistente sobre a parte maior do antocarpo, e em geral sofre também um ligeiro espessamento, sendo constituída pela parte superior do tubo e os lobos do cálice (Fig. 5). Apesar de (Heimerl 1934) denominar a porção superior do tubo do cálice como lobos ou dentes do cálice, consideramos inadequada tal denominação e preferimos usar nesse trabalho os termos cúpula apical quando a porção superior do tubo do cálice no antocarpo tem forma globosa, e é mais ou menos fechada e inflada como ocorre na maioria das espécies de Neea (Fig. $5 \mathrm{~N}-\mathrm{X}$ ), e de coroa apical a porção superior do tubo do cálice no antocarpo é aberta como em muitas espécies de Guapira (Fig. 5B-D, J). Burger (1983) refere que nas espécies de Neea da Costa Rica, a porção superior do tubo do cálice é usualmente decídua, tal situação não ocorre nas espécies brasileiras do gênero, mas frequentemente, essa porção não aparece completa, devido a processo de predação por insetos.

Os antocarpos fornecem bons caracteres para separação dos gênero na tribo Pisonieae. Em Pisonia são clavados, secos e apresentam glândulas bem evidentes (Fig. 5A). Em Guapira e Neea são globosos a oblongos, carnosos e sem glândulas, e apesar de muito semelhantes entre si, podem ser diferenciados pela organização apical. Na maioria das espécies de Guapira ocorre uma coroa apical aberta e o fruto é protegido por uma forte ampliação do espessamento interno da flor pistilada (Fig. 5D). Em algumas espécies do cerrado como G. anoxia e G. graciliflora, a coroa apical é fechada e não ocorre o espessamento dos lobos do cálice (Fig. 5E-H). Também, nas espécies desse gênero, geralmente não se encontram rudimentos de antera dentro desta coroa. Em Neea frequentemente ocorre espessamento da porção superior do tubo, que em geral é globosa e abaulada, e os lobos do cálice tornam-se constritos formando uma cúpula apical onde normalmente são encontrados os rudimentos de antera (Fig. 5O-U).

Todos os embriões analisados em Pisonieae são retos com os cotilédones enrolados lateralmente, caráter diagnóstico da tribo (Fig. 5K-O,Q). Porém, pode haver variação na forma do antocarpo até na mesma espécie. Em Guapira pernambucensis podem ocorrer antocarpos globosos, once o embrião apresenta a radícula bastante flexionada para o lado interno, e antocarpos oblongos onde o embrião é reto.

Pólen, polinização e dispersão - Fiedler (1910) descreveu o pólen de Pisonia aculeata e de Neea theifera como possuindo 3 colpos longos. Skottsberg (1936) ao estudar os grão de pólen das espécies de Pisonieae do Havaí, descreveu para Rockia pólen 3colpado e para Calpidia pólen 6-12-colpado. Novicke \& Luikart (1971) referem a presença na tribo Pisoneae de pelo menos quatro tipos polínicos distintos, e consideram que essa diversidade polínica poderia fornecer um bom parâmetro para o alinhamentos dos gêneros.

Barth \& Barbosa (1972) estudaram os grãos de pólen de seis espécies de Pisonieae do Brasil, e referem que todas apresentam grão de pólen colpado, sendo 4-colpados em Neea pendulina e $N$. schwackeana; constantemente 3-colpados em Pisonia aculeata, $P$. ambigua e Guapira opposita var. warmingii, e variando de 3- a 4-colpados em Guapira asperula e G. opposita var. opposita. As autoras descrevem a exina das espécies de Neea como baculada, e de Pisonia e Guapira como espinulada, mas sem possibilitar distinção entre as espécies.

Muito pouco se sabe sobre e polinização em Nyctaginaceae e especialmente em Pisonieae. Nesta tribo, devido à dioicia não ocorre autopolinização, sendo as espécies provavelmente polinizadas por insetos devido as anteras excertas, com exceção de Neea. Em alguns espécimes de herbário, por exemplo em Guapira obtusata, coletada por Araujo 7894, constam informações de que as flores são muito aromáticas e bastante visitadas por borboletas. Chodat \& Rehfous (1926) relatam que em Pisonia aculeata as flores são visitadas por dípteros e pequenos himenópteros.

Também, há poucos dados sobre a dispersão nas espécies de Pisonieae. Segundo Chodat \& Rehfous (1926) em Pisonia aculeata as infrutescências com seus antocarpos maduros se destacam por inteiro da planta, e caem no sobosque da floresta, e a infrutescência inteira, através dos tricomas glandulares do antocarpo, se adere aos pêlos dos animais. Os autores referem que os tricomas glandulares tem a célula apical não secretora, e esse fato provavelmente ajudaria a não adesão das infrutescências aos ramos e folhas do dossel. Segundo Jimbo (1962) os antocarpos carnosos de Guapira são muito apreciados por aves e provavelmente também por outros grupos de animais frugívoros. Contudo, em diversas populações naturais de Guapira opposita foram vistos muitos antocarpos intactos no solo.

Distribuição geográfica e habitats - A tribo Pisonieae como definida por Douglas \& Spellenber (2010), é bem sustentada pelos dados moleculares, incluindo quatro gêneros: Guapira, Neea, Pisonia e Pisoniella, tem distribuição pantropical que é dada pelo gênero Pisonia, sendo os restantes de distribuição neotropical (Stemmerik 1964, Eckardt 1964). Guapira e Neea ocorrem do sul da América do Norte, passando pela América Central até a América do Sul (Standley 1918, 1922, 1931b e 1937a), enquanto Pisoniella ocorre no México, Bolívia e Argentina (Standley 1911, Heimerl 1911) (Fig. 6).

As três espécies de Pisonia, ocorrem principalmente nas regiões Sul, Sudeste e parte da região Centro-Oeste, e poucos indivíduos atingem a região litorânea do Nordeste, havendo ainda a ocorrência de uma única coleta na região Norte, no 


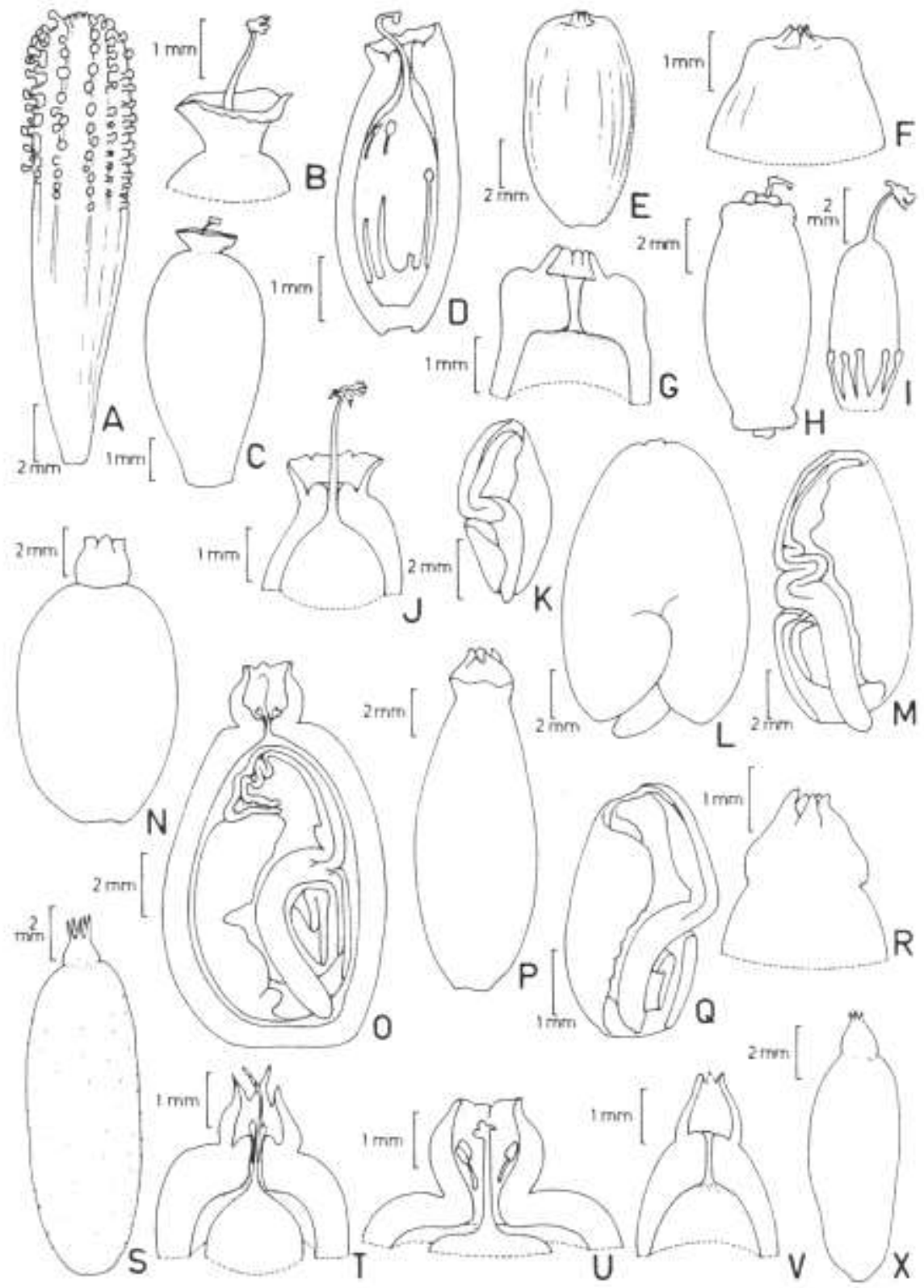

Fig. 5 - Antocarpos e embriões de Pisonieae: A. Pisonia zapallo, antocarpo com glândulas. B. Guapira nitida, ápice do antocarpo. C. idem, antocarpo. D. G. pernambucensis, antocarpo em corte longitudinal. E. G. graciliflora, antocarpo. F. Idem, ápice do antocarpo. G. G. noxia, ápice do antocarpo em corte longitudinal. H. Idem, antocarpo jovem. I. Idem, frutos e estaminódios. J. G. opposita, ápice do antocarpo em corte longitudinal. K. G. pernambucensis, embrião em corte longitudinal. L. G. venosa, embrião em vista dorsal. M. Idem, embrião em corte longitudinal. N. N. macrophylla, antocarpo. O. Idem, antocarpo e embrião em cone longitudinal. P. N. pendulina, antocarpo. Q. N. duckei, embrião em corte longitudinal. R. Idem, ápice do antocarpo. S. N. ovalifolia, antocarpo. T. Idem, ápice do antocarpo em corte longitudinal. U. N. macrophylla, ápice do antocarpo em corte longitudinal. V. N. hermaphrodita, ápice do antocarpo em corte longitudinal. X. Idem, antocarpo. (A - A. Pott et al. 4919; B, C - A. Furlan et al. 1214; D - A.M. Carvalho \& T. Plowmann 1602; E, F - M.L.M. Azevedo \& A.L. Brochado 665; G-I R.C. Vieira et al. s.n. HUFU 194; J - R. Callejas 1578; K- L.A.M. Silva 2050; L-M - P. Lisboa 2095; N-O - A. Ducke s.n. RB 25640; P - Y.S. Kuniyoshi et al. 5569; Q-R - A. Ducke s.n. HAMP 15626; S-T - G.T. Prance 16047; U - D. Philcox et al. $3400 ; \mathrm{V}-$ $\mathrm{X}$ - M.A. Silva 65). 


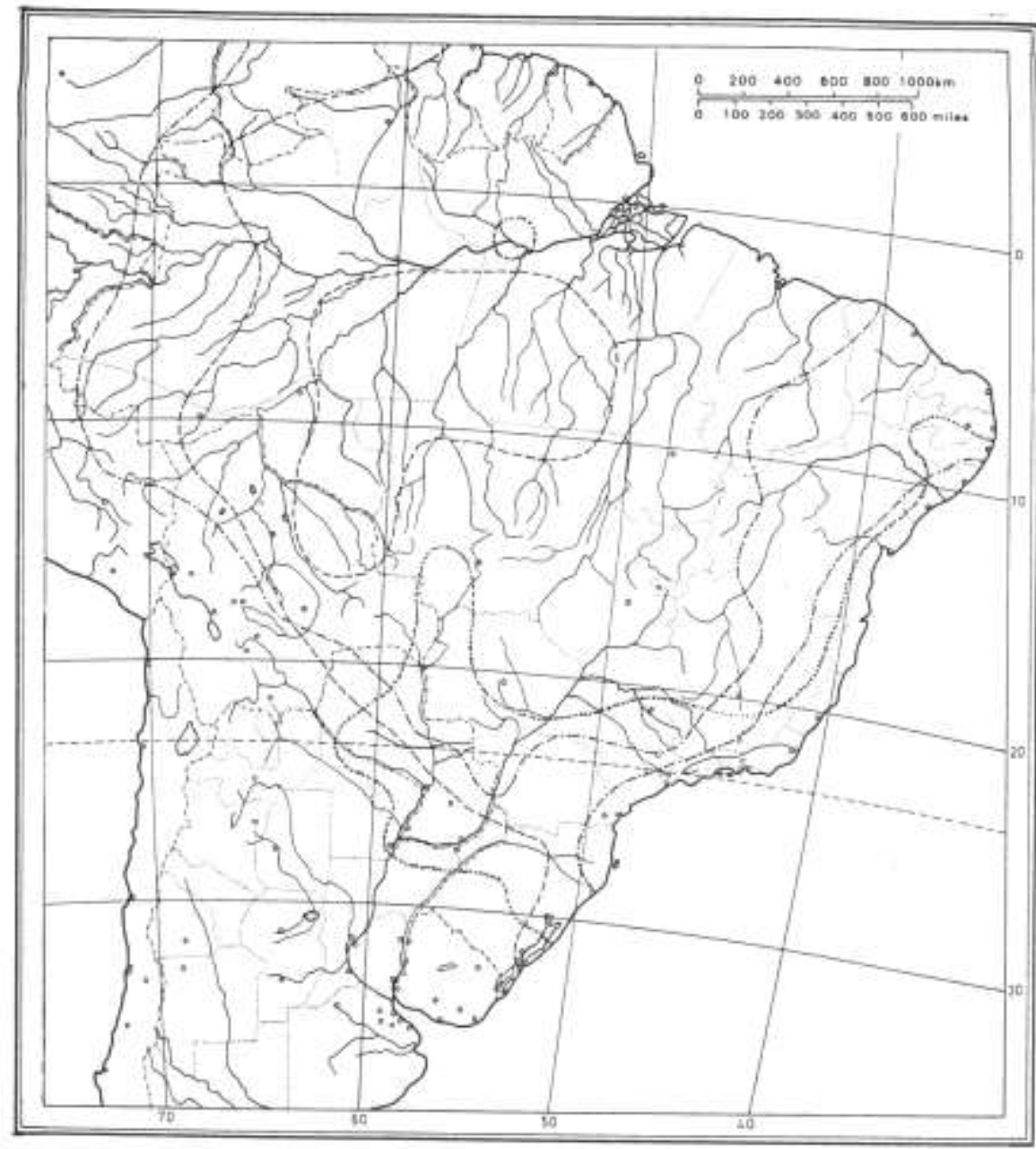

Fig. 6 - Distribuição geográfica dos gêneros da tribo Pisonieae no Brasil: Guapira (linha tracejada), Neea (linha tracejada intercalada com pontos), Pisonia (linha pontilhada).

Pará. $P$. aculeata é a espécie com mais ampla distribuição, ocorrendo na América do Norte, Estados Unidos (Flórida) e México, no Caribe, na América Central e na América do Sul, desde a Colômbia e Perú, até o Paraguai e norte da Argentina (Burger 1983, Liesner 1993, Standley 1918, 1931b, Toursarkissian 1975). Pisonia zapallo ocorre apenas na região do Chaco úmido e pantanal matogrossense, e $P$. ambigua distribui-se desde o Paraguai, até as regiões Sul e Sudeste do Brasil, atingido o sul do Estado da Bahia.

Guapira ocorre em todas as regiões do Brasil, porém apresenta baixa frequência na região amazônica, onde são referidas poucas coletas de $G$. opposita, G. hirsuta e G. venosa. A ultima dessas espécie apresenta grande disjunção, ocorrendo na região amazônica e no sul da Bahia, mostrando um padrão semelhante ao de várias espécies de Neea. Até o presente, é evidente a ocorrência de uma lacuna de espécies de Guapira no sul da Amazônia. Tal situação deverá ser melhor estudada, pois aparentemente não é decorrente de insuficiência de coletas, pois na mesma área foram coletadas várias espécies de Neea. Guapira apresenta uma distribuição peri-amazônica não muito típica, semelhante ao tipo IV de Granville (1992), com ocorrência no norte, oeste e sudoeste da Amazônia.

Na região litorânea concentram-se as espécies Guapira hirsuta, G. nitida, G. obtusata, G. opposita e G. pernambucensis, todas com predominância de inflorescências com ramificação verticilada ou umbelada, enquanto que nas regiões de cerrado ocorrem principalmente $G$. areolata, G. campestris, $G$. graciliflora e $G$. noxia, com outros tipos de ramificação da inflorescência. G. laxa ocorre tanto em área de caatinga como de restingas, $G$. tomentosa é restrita a áreas de campos de altitude ou campos rupestres, e G. venosa principalmente ao norte da amazônia. Potanto, Guapira tem um centro de diversidade nas regiões sudeste e nordeste do Brasil (10 espécies), e 
outro centro no norte da Amazônia, uma vez que Standley (1931b) refere 12 espécies de Torrubia (=Guapira) na Colômbia e Venezuela, e Steyermark (1987) refere 15 espécies do gênero para a Venezuela.

Em Neea, exceto $N$. theifera e $N$. pendulina, todas as outras 13 espécies do gênero que ocorrem no Brasil, têm representação na Amazônia. Standley (1918) refere a ocorrência de 15 espécies do gênero para a América Central. Standley (1937a) refere 12 espécies para a amazônia peruana, e Steyermark (1987) refere 23 espécies para a Venezuela, das quais 18 são novas espécies. Por esses dados, a Amazônia é o principal centro de diversidade do gênero Neea. No Brasil seis espécies, Neea duckei, $N$. floribunda, $N$. hirsuta, $N$. laxa, $N$. ovalifolla e $N$. verticillata, apresentam um padrão de distribuição disjunto com concentração maior das populações na Amazônia e menor na região litorânea leste, especialmente no sul da Bahia. Esse é um padrão bastante similar ao apresentado anteriormente para Guapira venosa. As espécies $N$. theifera, $N$. hermaphrodita e $N$. macrophylla têm distribuição associada ao Bioma

Usos - Os representantes de Pisonieae têm utilidade econômica limitada. Segundo Netto (1866a) as folhas de algumas espécies fornecem tinta negra para tingir algodão. Baillon (1875) cita principios ativos nas raízes purgativas de Pisonia, e que algumas espécies deste gênero seriam cultivadas pela beleza e perfume das inflorescências. Os frutos muito glandulosos das espécies de Pisonia foram utilizados no Havaí para caçar pássaros (Hillebrandt 1888, apud Chodat \& Rehfous 1926). Ruiz \& Pavon (1798) comentam que no Peru os nativos esfregam o suco dos frutos de Neea verticillaia nas mãos, pés e rosto como proteção contra picadas de insetos. $\mathrm{Na}$ Amazônia, a casca de uma espécie indeterminada de Neea, de nome vulgar "pão-de-cobra" ,forneceria aos nativos um suposto antídoto ao veneno de cobra (Porto 1936). Segundo Stoemi (1944) as cinzas de Pisonia zapallo contêm muitos sais e por isso são usadas na fabricação de sabão. Devido ao lenho forte, duro e resistente à quebra, Hess (1946) comenta a utilidade de $P$. zapallo em construções e na confecção de caixas. Shaw (1952) mostra que $P$. alba Span. "árvore-couve" é a forma cultivada de $P$. grandis R. Br. da Ásia, utilizada como hortaliça. Reitz et al. (1978) indicam algumas espécies da tribo, como Guapira opposita e Pisonia ambígua, como adequadas ao uso em reflorestamento.

\section{Chave para os gêneros de Pisonieae no Brasil}

1. Inflorescências geralmente em cimeiras capitado-aglomeradas; flores pistiladas sempre e estaminadas frequentemente com séries longitudinais de minúsculas glândulas; antocarpos secos, clavados, com séries longitudinais de glândulas; bractéolas distanciadas entre si ao longo do ramo distal da infrutescência .............

1'. Inflorescências geralmente em cimeiras ou umbelas laxas; flores sem séries longitudinais de minúsculas glândulas; antocarpos carnosos, globosos ou elipsóides, sem glândulas; bractéolas dispostas logo abaixo do antocarpo.

2. Ramos distais da inflorescência geralmente em cimeiras trifloras; botões clavados, ápice truncado, 5radiado, com induplicações salientes; flores estaminadas campanuladas, estames excertos; flores pistiladas com estigma penicelado-radiado bem saliente do cálice; ápice do antocarpo com os dentes das

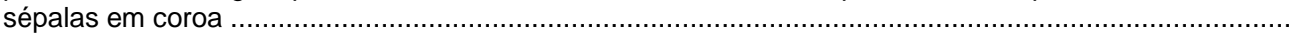

2'. Ramos distais da inflorescência em cimeiras multifloras; botões globosos, elipsóides ou oblongos, ápice arredondado ou agudo, sem induplicações salientes; flores estaminadas urceoladas, raro campanuladas, estames inclusos; flores pistiladas com estigma agudo, papiloso, raro pouco fimbriado unilateralmente ou foliáceo lacerado, pouco ou nada saliente do cálice; ápice do antocarpo com uma camara em cúpula e dentes das sépalas em coroa no ápice desta câmara

1. GUAPIRA Aubl., Hist. pl. Guian.
écie-tipo: Guapira guianensis Aubl.

Torrubia Vell., Fl. flumin. : 139. 1829.

Bessera Vell., FI. flumin. : 147. 1829.

Columella Vell., FI. flumin. : 155. 1829.

Árvores, arvoretas ou arbustos lenhosos, raramente com ramos subescandentes, inermes, frequentemente ramificados dicotomicamente a cada 2 nós, raramente tricotomicamente. Folhas opostas a subopostas nos nós não ramificados, em geral verticiladas nos nós ramificados, pares iguais ou pouco desiguais, coriáceas a membranáceas, pecioladas ou menos frequentemente sésseis. Inflorescências terminais ou pseudo-axilares, às vezes caulifloras, normalmente laxas, ramos da inflorescência verticilados, subverticilados, opostos e geralmente patentes, ou alternos e geralmente oblíquos, ramos distais comumente com cimeiras trifloras ou aglomeradas; bráctea 1, na base das flores e frequentemente na base das címulas, às vezes na base dos ramos, raramente no meio dos ramos; bractéolas 2, geralmente persistentes na base dos antocarpos, raramente decíduas. Flores diclinas, monoclamídeas, pequenas, sésseis ou muito raramente com as flores centrais das címulas curtopediceladas, 5-meras, raramente 4-meras; botões florais tubulosos ou clavados, ápice truncado, induplicado-valvar, induplicações salientes. Flores estaminadas em geral tubuloso-campanuladas, abertas; cálice membranáceo a carnoso, lobos em geral patentes; estames 5-11, frequentemente 8, desiguais, exsertos do cálice, filetes unidos na base, 
brancos, anteras com tecas iguais ou pouco desiguais; pistilódio presente, incluso, raramente ligeiramente saliente; estigma não desenvolvido. Flores pistiladas tubulosas, pouco contraídas na região mediana, lobos normalmente eretos a pouco patentes, cálice espessado internamente, especialmente na região mediana; estaminódios 4-9, filetes pouco desenvolvidos na frutificação, anteróides geralmente orbiculares, compressos; ovário séssil ou ligeiramente estipitado, globoso a alongado, estilete cilíndrico, estigma penicelado-radiado, branco, excerto do perianto. Antocarpo carnoso, geralmente elipsoide raramente globoso, de cor rosa a preta, brilhantes; lobos persistentes do cálice pátulos, eretos, ou fechados, e quando fechados frequentemente pilosos. Fruto aquênio, pericarpo membranáceo, ajustado ao antocarpo; semente com testa aderida ao fruto, embrião reto, cotilédones desiguais, carnosos, radícula reta no antocarpo elipsoide, ou curva no antocarpo globoso, perisperma pouco gelatinoso.

Guapira foi descrito por Aublet (1775), mas o nome só voltou a ser utilizado a partir do trabalho de Woodson Jr. \& Kidd (1961) na Flora do Panamá, para referir as espécies com antocarpos carnosos, incluídas em Pisonia sect. Eupisonia Heimerl. Por algumas décadas houve grande controvérsia sobre uso dos nomes Guapira ou Torrubia Vell., gênero restabelecido por Britton (1904). Standley (1916), propôs 32 novas combinações nesse gênero, a partir de espécies previamente descritas em Pisonia. Com a rejeição da proposta de Little Jr. (1964) para conservação de Torrubia em relação a Guapira Aubl., Gynastrum Neck, Bessera Vell. e Columella Vell. pelo Comitê de Spermatophyta (McVaugh 1968), Little Jr. (1968) iniciou a transferência das espécies de Torrubia e das espécies de Pisonia com antocarpos carnosos para Guapira, fazendo oito combinações novas, e sendo acompanhado por Lundell (1968) que propôs 60 combinações novas em Guapira.

A comparação das ilustrações de Guapira guianensis Aublet (1775) e de Torrubia opposita Vellozo (1831) mostra claramente que as plantas ilustradas são pertencentes ao mesmo gênero, embora não da mesma espécie. Ambas apresentam folhas opostas, flores monoclamídeas com uma bráctea e duas bractéolas e seis estames excertos, sendo três maiores e três menores,

Os três gêneros descritos por Vellozo (1829) foram diferenciados na diagnose pelo tipo de perianto e número de estames. Torrubia teria flores com pétalas ausentes e seis estames; Bessera teria flores com cálice tubuloso campanulado, sem corola e sete estames; e Columella teria flores sem cálice e com corola monopétala e oito estames. Porém, as ilustrações dos gêneros em Vellozo (1831) incluem plantas similares com inflorescências verticiladas laxas e címulas trifloras e flores com estames excertos. A análise de muitos espécimes de Guapira tem mostrado que ocorre entre as espécies grande variação no número de estames, e tal variação ocorre mesmo dentro de uma espécie ou num mesmo indivíduo, tornando impossível reconhecer os três gêneros propostos por Vellozo (1828). As ilustrações apresentadas indicam que provavelmente todas pertencem a Guapira opposita, que apresenta uma grande variabilidade morfológica.

Apesar de Guapira ser considerao um nome aceito, Howard (1983) transferiu a espécie-tipo do gênero, G. guianensis Aubl. para o gênero Pisonia propondo a combinação nova Pisonia guianensis (Aubl.) R. A. Howard.

Neste trabalho, o gênero Guapira está sendo considerado como distinto de Pisonia e de Neea, decisão apoiada no estudo de aproximadamente 2200 espécimes pertencentes a Guapira, todos perfeitamente separáveis de Pisonia e Neea.

Sá (2010) no Catálogo de Plantas do Brasi referiu 11 espécies de Guapira, das quais apenas $G$. laxa não consta.

$\mathrm{Na}$ chave de identificação das espécies de Guapira, foram utilizados com principais caracteres diferenciais, a forma da folha e persistência ou não da pilosidade, o tipo e estrutura da inflorescência e a organização das flores estaminadas, devido à maior frequência deste tipo de flor na natureza e por consequência nas exsicatas depositadas em herbários.

Chave para as espécies de Guapira do Brasil

1. Inflorescência adulta com ramos primários, predominantemente opostos a sub-opostos, geralmente patentes, ou pedúnculos dicotômicos com ramos em geral oblíquos; antocarpo geralmente de coroa fechada.

2. Inflorescências principalmente em ramos velhos suberificados; folhas grandes, glabras, nervuras muito salientes na face inferior...................................................................................................... 1.12. G. venosa

2'. Inflorescências terminais e axilares normalmente em ramos novos; folhas em geral pequenas, glabras ou pilosas, nervuras em geral pouco ou não salientes.

3. Pedúnculos da inflorescência geral ramificados dicotomicamente com os ramos primários oblíquos.

4. Folhas adultas sub-sésseis, com margem crenada acompanhando a curvatura das nervuras, base e ápice arredondados

4'. Folhas adultas em geral pecioladas, com margem normalmente lisa, ou se irregular não acompanhando a curvatura das nervuras.

5. Ramos da inflorescência com a região mediana portando brácteas; flores estaminadas glabras ou com tricomas ferrugíneos esparsos na base, lobos do cálice reflexos; folhas adultas em geral elípticas, reticuladas, glabras ou com a face inferior portando tricomas esparsos, margem frequentemente irregular,; folhas novas elípticas. 
5'. Ramos da inflorescência com brácteas apenas na base dos ramos finais; flores estaminadas com indumento ferrugíneo, lobos do cálice eretos; folhas adultas orbiculares, elípticas ou rômbicas, face inferior denso ferrugíneo-tomentosa, margem inteira; folhas novas oval-elípticas

3'. Pedúnculos da inflorescência geral ramificados dicotomicamente com os ramos primários geralmente opostos a sub-opostos e normalmente patentes.

6. Gemas grandes, 3-5 mm diam.; pecíolos 6-26 mm compr., espessos; flores estaminadas grandes, até

$7,0 \mathrm{~mm}$ compr.; anteras com mais de $1 \mathrm{~mm}$ compr.

6'. Gemas pequenas, até 2,0 mm diam.; pecíolos 1-7 mm compr., delgados e frequentemente sub-alado devido a base atenuada da folha; flores estaminadas pequenas, até $4,5 \mathrm{~mm}$ compr.; anteras até 0,8 $\mathrm{mm}$ compr.

1'. Inflorescências adultas com ramos primários predominantemente verticilados ou aglomerados subverticiladamente, podendo ocorrer às vezes um primeiro ramo isolado alterno e logo a seguir o verticilo de ramos primários; antocarpos geralmente de coroa aberta.

7. Folhas jovens com a face inferior ou as duas faces pilosas, folhas adultas pilosas, às vezes apenas ao lado da nervura mediana, ramos finais geralmente hírtulos.

8. Inflorescências aglomeradas, geralmente capituliformes, 5-27 mm larg.; folhas elípticas normalmente buladas, margem bem revoluta; antocarpo com coroa ereta; flores estaminadas hírtulas, pouco abertas,

lobos do cálice eretos. ....................................................................................................... 1.11.

8'. Inflorescências laxas, 21-118 mm larg.; folhas elíptico-lanceoladas a oblongas, nunca buladas,
pouco ou não revoluta; antocarpo com coroa aberta; flores estaminadas pouco pilosas na base, campanuladas, abertas, lobos do cálice reflexos.

9. Arbustos ou árvores; folhas elíptico-lanceoladas a lanceoladas, geralmente pequenas e estreitas, 4,2-

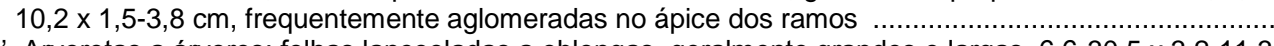

9'. Arvoretas a árvores; folhas lanceoladas a oblongas, geralmente grandes e largas, 6,6-30,5 × 3,2-11,3 $\mathrm{cm}$, em geral distanciadas entre si ...........................................

7 '. Folhas jovens e adultas glabras, ramos finais geralmente glabros.

10. Folhas sésseis ou com pecíolo até $6 \mathrm{~mm}$ compr., base cordada a arredondada

10 '. Folhas com pecíolo 2-26 mm compr., base aguda ou raramente obtusa.

11. Folhas oboval-orbiculares a obovais, base aguda, frequentemente atenuada no pecíolo, ápice arredondado a obtuso; inflorescências com pedúnculos espessos e rígidos, em geral eretos; flores estaminadas frequentemente com pistilódio saliente 1.10. G. pernambucensis 1.4. G. hirsuta 1'. Folhas elípticas a elíptico-lanceoladas, raramente largo-elípticas, base aguda a raramente obtusa, ápice agudo, raramente obtuso; inflorescências com pedúnculos flexíveis; flores estaminadas com pistilódio incluso 1.8. G. obtusata 1.7. G. noxia 1.3. G .graciliflora 11. G. tomentosa 1.9. G. opposita

1.1. Guapira areolata (Heimerl) Lundell, Wrightia 4(2): 82. 1968. इ Pisonia areolata Heimerl, Vidensk.Meddel. Dansk Naturhist. Foren 1890: 159. 1891. 三 Torrubia areolata (Heimerl) Standl., Contr. U.S. Natn. Herb. 18(3): 100. 1916. Tipo: Brasil, "ad Lagoa Santa, fl. est.", E. Warming s.n. (lectótipo K!, isolectótipo P!, aqui designados).

= Pisonia luteovirens Heimerl, Oest. bot. Z. 56: 425. 1906. $\equiv$ Torrubia luteovirens (Heimerl) Stand Contr. U.S. Natn. Herb. 18(3): 100. 1916. 三 Guapira luteovirens (Heimerl) Lundell, Wrightia 4(2): 82. 1968. Tipo: Paraguai, "in regione cursus superioris fluminis Apa", Hassler 7813 (lectótipo G!, isolectótipos K!, P!, MO!). Syn.nov.

= Pisonia paraguayensis Heimerl, Verh. zool.-bot. Ges. Wien 62: 7. 1912. इ Torrubia paraguayensis (Helmer) Stand., Contr. U.S. Natn. Herb. 18(3): 101. 1916. I Guapira paraguayensis (Helmer]) Lundell, Wrightia 4(2): 83. 1968. Tipo: Paraguai, "nordl. Parag., zwischen Rio Apa and Aquidabam", fem., fr. imaturos, K. Fiebrig 4767A (lectótipo, G!, isolectótipos K!, P!, aqui designados). Syn.nov.

= Pisonia cacerensis Hoehne, Com. lin. telegr., Bot. Anexo 5(5): 70. 1915. Tab.109. I Pisoniella cacerensis (Hoehne) M.Lisboa, Escola de Minas e Metalurgia, Ouro Preto: 2. 1974. Tipo: Brasil, "Orin silvis humidis ad S. Luiz de Cáceres", IX.1911, F.C. Hoehne 5035 (lectótipo R! aqui designado). Syn. nov.

Fig. 7

Nome vulgar: juá-mole (Ratter 2471).
Arbustos, arvoretas a árvores, 1,5-18,0 m alt., fuste às vezes até $10,0 \mathrm{~m}$ alt., cilíndrico ou achatado, caule 13,0-28,0 cm diam., casca áspera, copa 5,0-8,0 $\mathrm{m}$ diam.; ramos velhos lenhosos, cilíndricos, usualmente bifurcados, ca. $10 \mathrm{~mm}$ espessura, os distais mais delgados; ramos novos até $3 \mathrm{~mm}$ espessura, estriados, frequentemente aglomerados nos ápices de ramos velhos, glabros ou às vezes pubérulo-ferrugíneos, quando secos pretos, enrugados, estriados; entrenós 2,5-8,5 cm compr., 3-8 entre cada ramificação nos ramos novos, usualmente os basais mais curtos ou muito curtos; cicatrizes foliares 1,2-3,0 mm larg., sub-cordiformes; gemas ca. $1,5 \mathrm{~mm}$ diam., pubérulo-ferrugíneas. Folhas com pecíolo 0,6-2,8 cm compr., até $2 \mathrm{~mm}$ espessura, frequentemente sub-alado devido a base atenuada das folhas, glabro ou pouco hírtulo-ferrugíneo na face inferior, quando seco canaliculado na face superior e estriado na face inferior. Laminas (4,0-) 6,2-20,5 $x$ 2,8-9,5 cm, elípticas, ligeiramente obovadas, frequentemente sub-romboidais, base aguda a obtusa, atenuada no pecíolo, ápice agudo a obtuso, curto ou longo-caudado, ou largo-acuminado, acúmen obtuso, largura maior no meio ou pouco mais acima, usualmente glabras, raro poucos tricomas esparsos na face inferior, mais concentrados ao lado da nervura mediana, margem frequentemente irregular, normalmente predadas; quando secas verde-olivácea a pardo-clara, às vezes com manchas negras, cartáceas a subcoriáceas, frequentemente espessas, 


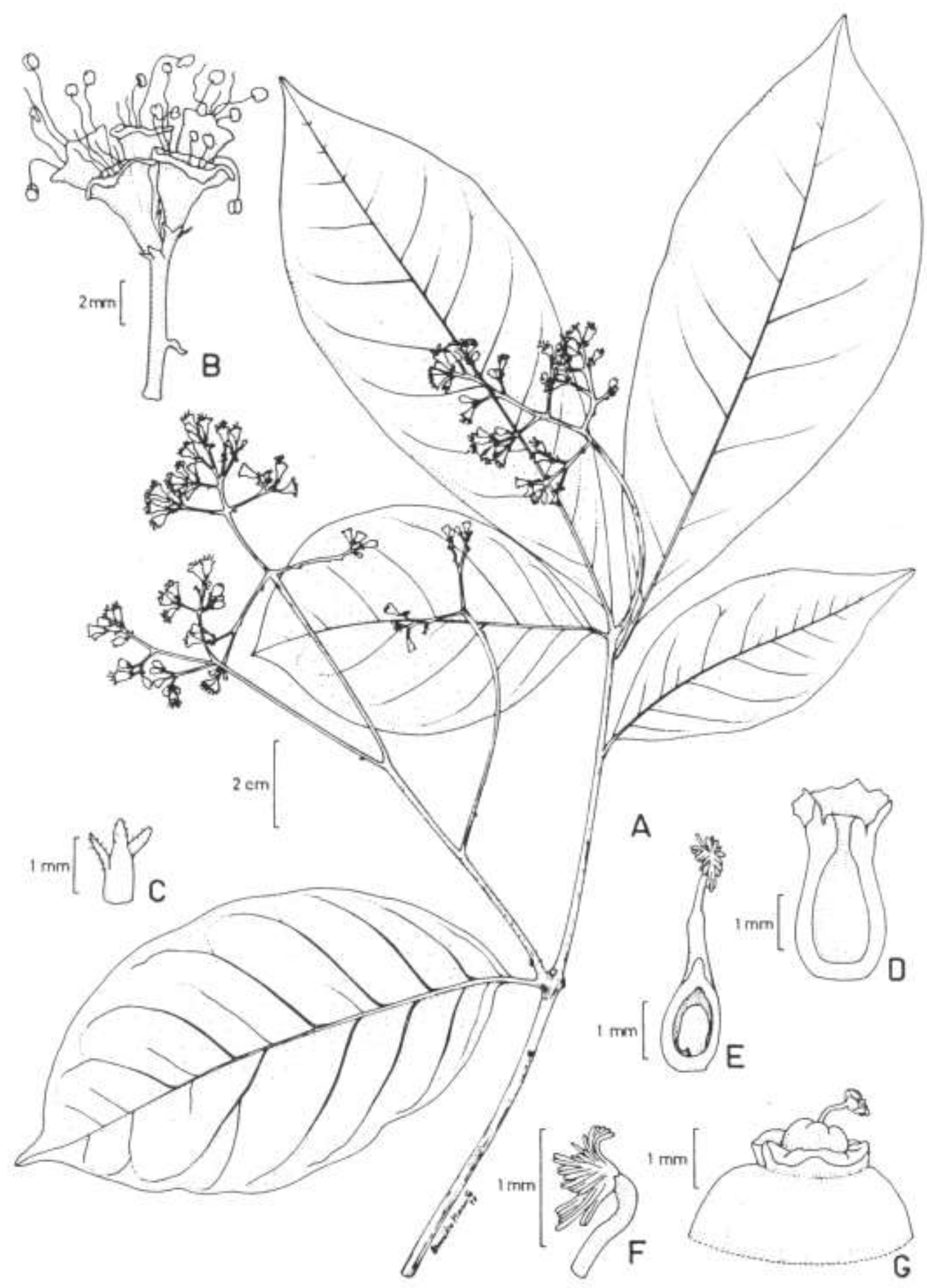

Fig. 7 - Guapira areolata: A. Ramo de planta estaminada. B. Ramo distal de uma inflorescência estaminada mostrando brácteas no meio dos ramos. C. Brácteas e bractéolas em níveis ligeiramente diferentes e pilosidade desigual. D. Cálice pistilado em corte longitudinal, com notável espessamento interno. E. Ovário em corte longitudinal. F. Detalhe do estigma pedicelado. G - Ápice do antocarpo mostrando o espessamento interno saliente.(A - F.C. Hoehne 5035; B-C - G. Hatschbach 30491; D-G - A.P. Silva et al. 160). 
opacas, nervuras pouco ou muito salientes nas duas faces, exceto na nervura mediana impressa na face superior na região basal; folhas novas elípticoobovadas a orbicular-obovadas, base aguda atenuada, ápice obtuso, acuminado ou curto acuminado, face superior glabra, face inferior hírtulotomentosa, quando seca enegrecida ou verde enegrecida, ou às vezes com a face inferior de cor marrom, opaca, nervuras não salientes; tricomas creme-amarelados, unisseriados. Inflorescências 9,8$15,2 \times 4,6-11,2 \mathrm{~cm}$, não verticiladas, terminais em ramos curtos, glabras ou pouco pubérulo-ferrugíneas; pedúnculos 2,0-6,7 cm compr., ca. 1,6 mm espessura, eretos, bifurcados ou divaricados, às vezes lenticelados; ramos primários geralmente oblíquos e estriados, raramente opostos ou subverticilados, junções usualmente espessadas, ramos secundários bifurcados ou sub-opostos, quando secos compressos; cimeiras distais trímeras, frequentemente aglomeradas, raramente gemas ou flor isolada no meio dos ramos primários, ramos laterais das cimeiras pouco ou não desenvolvidos, pouco pilosos na região distal; brácteas 1,5-5,0 x 0,8-1,3 mm, linearlanceoladas a lineares, persistentes no meio dos ramos primários e secundários da inflorescência, às vezes também nos pedúnculos, face dorsal pilosoferrugíneas, especialmente no ápice e às vezes nas margens, normalmente decíduas; bractéolas 0,5-1,0 x ca. $0,5 \mathrm{~mm}$, deltoide-lineares, pouco pilosas, especialmente no ápice; botões estaminados 3,0-4,5 x 2,0-2,5 mm, clavados, verde-escuros; flores estaminadas 3,0-5,0 x 2,5-4,0 mm, campanuladas, creme a verde-amareladas, glabras ou com tricomas ferrugíneos esparsos principalmente na base; estames 6-8, salientes até 5,0 mm compr., brancos; anteras ca. 0,7 mm compr.; botões pistilados 1,5-2,5 x 0,5-0,8 $\mathrm{mm}$, cilíndricos, ligeiramente estreitados na região mediana; flores pistiladas 2,0-3,0 x 1,0-1,8 mm, verderosadas, estreitamento interno acima do meio, parte superior do tubo bem curta; estaminódios 8; estigma branco, saliente até $1,7 \mathrm{~mm}$ compr.; infrutescências $6,0 \times 13,0 \times 5,8-9,8 \mathrm{~mm}$, ramos patentes; pedúnculo 2,9-9,5 mm compr.; antocarpos 7,0-10,0 x 2,4-4,5 mm, elipsoide a ovoide, raro oblongos, às vezes truncado na base e no ápice, rosados a pretos, pretos quando secos; coroa aberta até pátula, raro coroa ereta, glabra, até $0,3 \mathrm{~mm}$ alt., às vezes com o espessamento interno saliente, quando seca creme-amarelada a enegrecida; embrião pouco carnoso, às vezes foliáceo.

Guapira areolata foi descrita por Heimerl (1891) com base nos sintipos Warming s.n. com flores estaminadas e escolhido com lectótipo e Glaziou 3083 uma planta com flores pistiladas. A espécie é similar com G. venosa, sobretudo pela permanência de brácteas persistentes nos ramos da inflorescência; folhas muitas vezes cartáceas e ligeiramente obovadas; e pelas nervuras pouco salientes. Contudo, em G. areolata não ocorre caulifloria nem flores dispostas de modo racemoso ao longo do ramo distal da inflorescência.
Pisonia luteovirens foi descrita por Heimer (1906c) baseada em dois sintipos: Malme s.n., coletado no Mato Grosso, Santa Anna da Chapada e Hassler 7813 do Paraguai, O autor considerou o novo táxon afim de $P$. noxia Netto, pela inflorescência com ramos quase patentes, mas não cita a presença de brácteas nos ramos da inflorescência. O exame dos espécimes coletados por Hassler 7813, mostra claramente duas inflorescências com pedúnculo bifurcado e uma com ramos pouco patentes a oblíquos; as três inflorescências mostram várias brácteas nos ramos das inflorescências. Não há semelhança entre G. luteovirens e G. noxia, especialmente pelas folhas e pilosidade completamente diferentes, mas há grande concordância com G. areolata pela folhas grandes, elíptico-lanceoladas, às vezes com pilosidade amarelada, enquanto que $G$. noxia possui folhas em geral orbiculares a oblongo-orbiculares, frequentemente com pilosidade ferrugíneoavermelhada, sendo por isso considerada um sinônimo da espécie.

Pisonia paraguayensis foi descrita por Heimerl (1912), com base em dois conjunto de espécimes coletados por Fiebrig. Os espécimes Fiebrig 4767A com flores pistiladas e frutos imaturos e Fiebrig $4767 B$ com flores estaminadas. O autor diferenciou a nova espécie "das espécies semelhantes neste difícil gênero" pela inflorescência raramente em umbela, estilete longo saliente e antocarpo não carnoso. O material Fiebrig 4767A (K), um dos isolectótipos da espécie, mostra a inflorescência sub-verticilada e as flores pistiladas com estigma bem saliente, e o espécime escolhido como o lectótipo (Fiebrig 4767A em $\mathrm{G}$ ), tem infrutescências, mostrando o pedúnculo bifurcado, antocarpos carnosos e folhas bem espessas. Estes caracteres estão incluídos na variação morfológica de $\mathrm{G}$. areolata. $\mathrm{Na}$ descrição de $P$. paraguayensis consta a presença de brácteas esparsas nos ramos da inflorescência, sendo este um dos caracteres mais constantes em G. areolata. Pelo exposto, $P$. paraguayensis é proposto como sinônimo de G. areolata.

Pisonia cacerensis é diferenciada das outras espécies do gênero por Hoehne (1915), pela inflorescência divaricada e pilosidade hírtula das folhas. O material-tipo da espécie Hoehne 5035, é uma planta com folhas jovens onde é visível a pilosidade hírtula das folhas, muito semelhante ao que ocorre com as folhas jovens em $G$. areolata. A ilustração, baseada neste mesmo material, mostra a inflorescência típica de $G$. areolata, com ramos bifurcados e brácteas no meio dos ramos, sendo por isso, a espécie sinonimizada nesse trabalho.

Distribuição geográfica e habitats (Fig. 8): ocorre principalmente nas regiões Centro-Oeste e Sudeste do Brasil até o Paraguai, geralmente associada a terrenos de calcário, paredões de arenito e matas de encosta. 


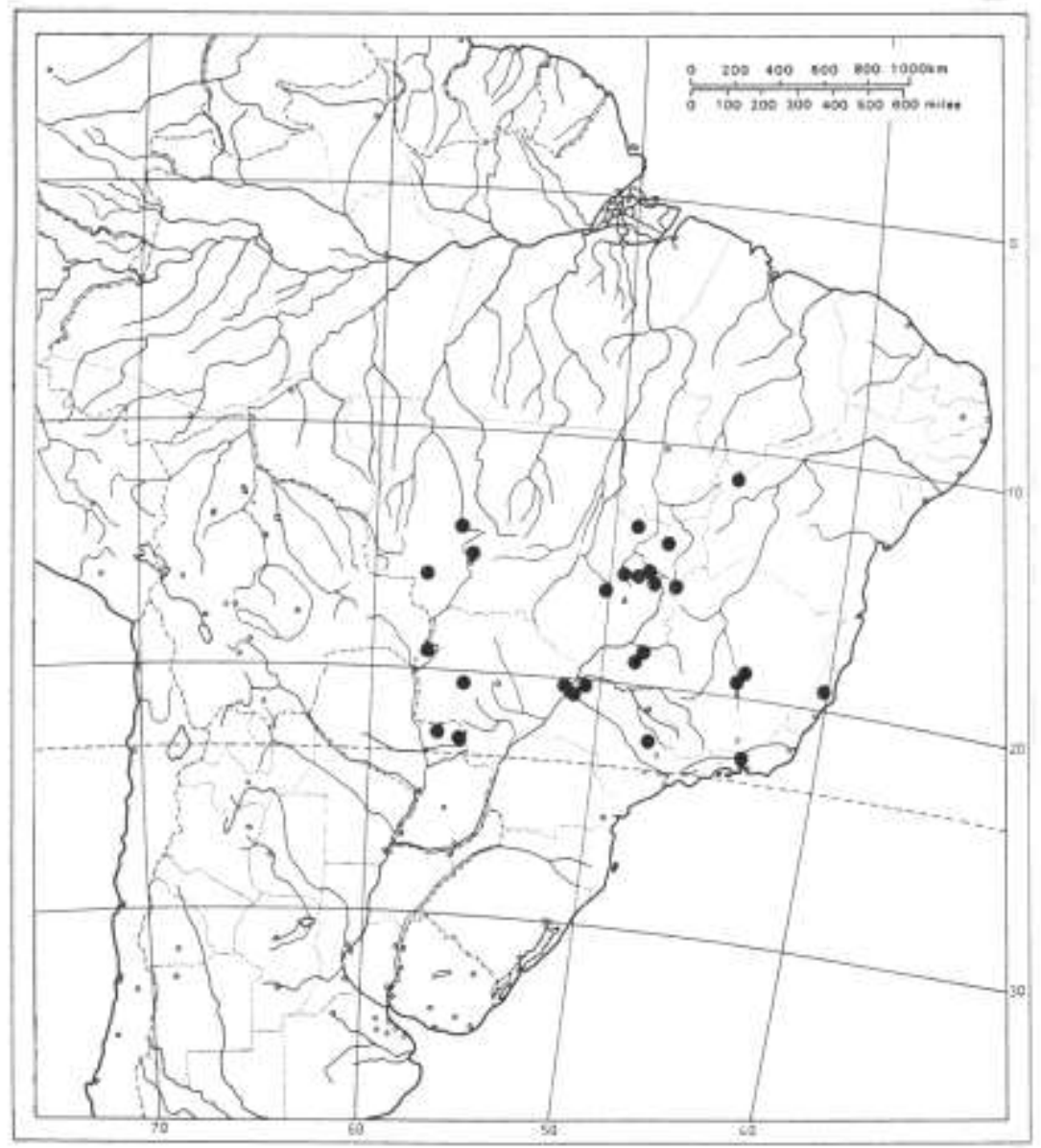

Fig. 8 - Distribuição geográfica de Guapira areolata.

Material selecionado: Brasil. Bahia: Formosa do Rio Preto, R.C. Mendonga et al. 1511, 13.X.1989, fl. pist. (IBGE). Distrito Federal: Brasília, M.L.M. Azevedo et al. 374 26.X.1989, fr. (IBGE). Espírito Santo: Linhares, I.A. Silva 137, 26.XII.1979, fl. est. (CVRD, RBR, SPF, HRCB). Goiás: Cabeceiras, H.S. Irwin et al. 10345, 16.XI.1965, fr. (MBM, NY, UB). Minas Gerais: Uberlândia, G.M. Araujo 558, 16.X.1989, fl. est. (HUFU, SPF). Mato Grosso: Chapada dos Guimarães, J.R.B. Monteiro et al. 113, 17.08.94, fr. (UEC). Mato Grosso do Sul: Silveira, J.Y. Tamashiro et al. 136, 6.XI.1985, fl. est. (CEN, ESA, HRCB, SP, UB, UEC). Rio de Janeiro: Petrópolis, A. Glaziou 3083, 29.IX.1868, fl. pist. (K, P, parte do síntipo de $P$. areolata). São Paulo: Jales, W. Hoehne s.n., 29.X.1951, fl. est. (HRCB, SPF 13926).

Paraguai. Entre rio Apa e Aquidabam, Fiebrig 4767B, 16.II.1909, fl. est. (G, K, P, parte do sintipo de $P$. paraguayensis); $22^{\circ} 39-56^{\circ} 03$, J.C. Solomon et al. 6910 , 13.II.1982, fr. (MO, SPF).

1.2. Guapira campestris (Netto) Lundell, Wrightia 4(2): 90. 1968. E Pisonia campestris Netto, Annals Sci.nat. 5a ser. Bot. 5: 83. 1866. E Torrubia campestris
(Netto) Standl., Contr. U.S. Natn. Herb. 18(3): 100. 1916. Tipo: Brasil, "in campis provinciae Piauhy", IX.1839, fl. est., Gardner 2944 (lectótipo K!, isolectótipo BM!, aqui designados).

Pisonia campestris Netto var. myrtifrons J.A.Schmidt in Mart., FI. Bras. 14(2): 360. 1872. Tipo: Brasil, Minas Gerais "in ripa fluvii S. Francisco prope Salgado", 2.IX.1818, fl. est./pist., Martius 1791 (holótipo M!). Syn. nov.

Pisonia campestris Netto var. glaucescens J.A.Schmidt in Mart., FI. Bras. 14(2): 360. 1872. Tipo: Brasil, "in campis Chapada do Paranan dictis in prov. Minas Geraes", IX.1818, fr., Martius 1816 (holótipo M!). Syn.nov.

Pisonia humilis Glaziou, Bull. Soc. Bot. Fr. 58, 4a ser., Mem. 3 f 560. 1911. Tipo: Brasil, "Goyaz, Forquilha, Foemos", 1896, A. Glaziou 21960 (holótipo $\mathrm{P}$ !, isótipos $\mathrm{K}$ !, BR!). Syn. nov.

Fig. 9

Arbusto a subarbustos, frequentemente reduzidos, 0,10-2,5 $\mathrm{m}$ alt., os menores em geral com 


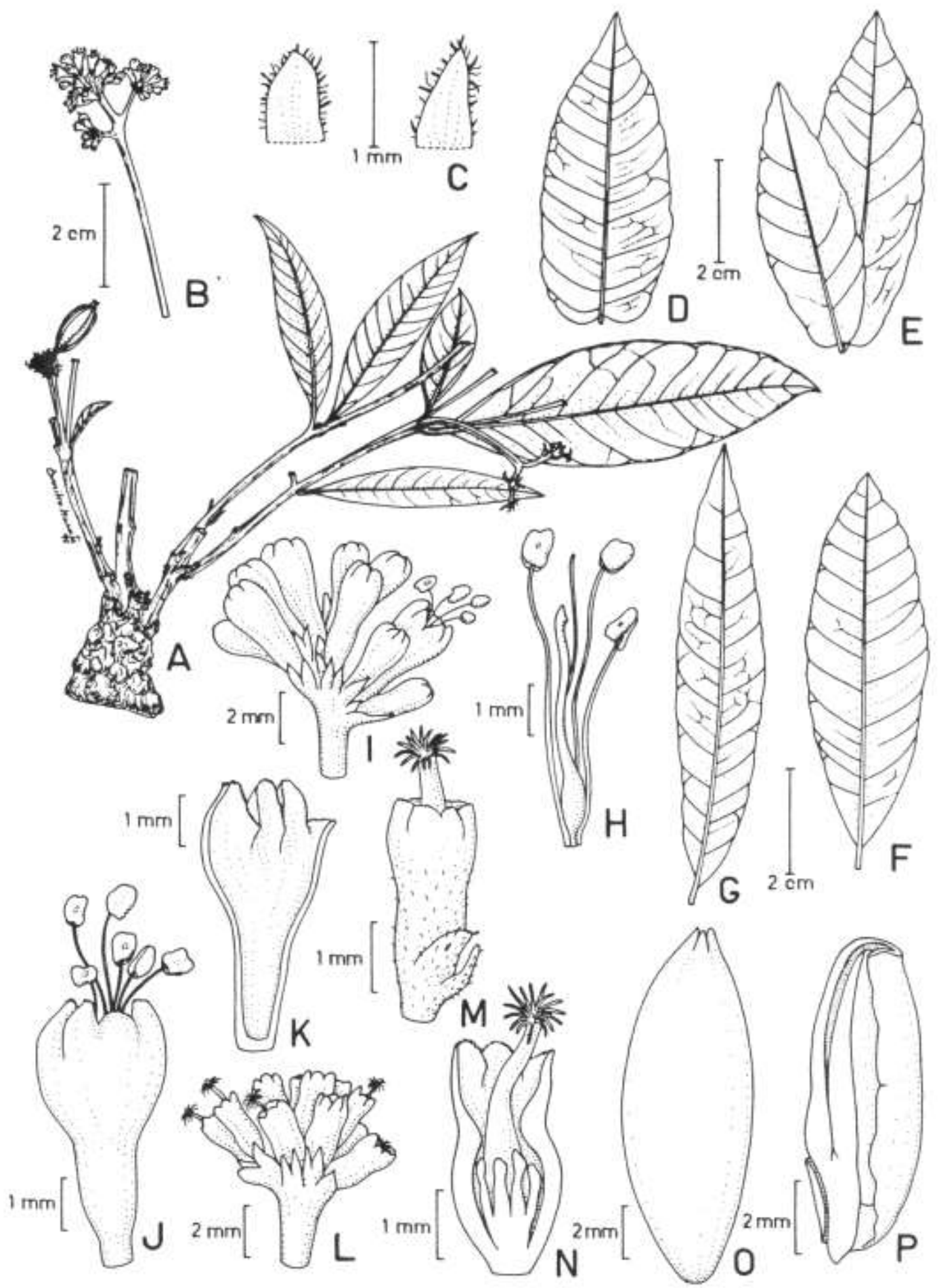

Fig. 9 - Guapira campestris: A. Planta anã com antocarpos. B. Inflorescência estaminada. C - Bractéolas. D-G - Variação foliar; margem foliar acompanhando as junções das nervuras primárias. H. Estames e pistilódios de uma flor estaminada. I. Ramo distal de uma inflorescência estaminada. J. Flor estaminada. K. Cálice estaminado em corte longitudinal. L. Ramo distal de uma inflorescência pistilada. M. Flor pistilada. N. Flor pistilada; cálice e em corte longitudinal. O. Antocarpo com coroa fechada. P. Embrião em corte longitudinal. (A - H.S. Irwin et al. 8340; B, H-K - G. Argent et al. 6533; C, L-N - H.S .Irwin e T.R. Soderstron 5987; D-E - H.S. Irwin e T.R. Soderstron 6680; F-G, O-P - H.S. Irwin e T.R. Soderstron 7061). 
vários caules originados do sistema subterrâneo lenhoso, ramificáveis caulinares dicotômicas abertas, os menores não ramificados ou ramos laterais alternos a subopostos, oblíquos, quase adnatos ao caule principal, às vezes florescendo sem folhas; ramos cilíndricos, lenhosos, não compressos e pouco estriados quando secos, glabros ou pubérulos, os menores ferrugíneos na base próximo do sistema subterrâneo; entrenós 9-32 mm compr.; cicatrizes foliares ca. 1,3 mm larg., raras em plantas reduzidas; gemas ca. 0,5 mm, ferrugíneo-avermelhadas, escuras. Folhas sésseis ou raramente pecíolo até $4,0 \mathrm{~mm}$. Laminas 3,8-9,8 x 1,6-2,8 cm, elípticas, ovadoelípticas a oblongas, as menores elíptico-lanceoladas a ovado-elípticas, raramente ovadas, opostas ou raramente alternas em plantas reduzidas, pares normalmente semelhantes, base arredondada a cordada, raramente aguda, ápice obtuso a arredondado, raramente agudo em folhas novas, margem inteira ou em plantas reduzidas crenulada acompanhando a curvatura das nervuras secundárias, glabras, as novas verde-avermelhadas com poucos tricomas ferrugíneos esparsos a glabrescentes, nervuras oblíquas, salientes embaixo, especialmente a nervura mediana, pouco ou não salientes em cima, quando secas cartáceo-coriáceas, reticuladas, muito brilhantes em cima, pouco embaixo, concolores, verde-parda a verde-oliva, articulação com o ramo em geral pouco murcha quando seca; às vezes folhinhas cordadas, alternas, 0,3 x 0,2 $\mathrm{mm}$ na base dos caules. Inflorescências terminais, 3,2-8,5 x 2,2-5,8 mm, glabras exceto nas axilas dos ramos; pedúnculos 3,36,3 mm. compr., normalmente estriados, ramos primários alternos ou subopostos, oblíquos, ramos distais frequentemente aglomerados; brácteas 2,2-3,2 $x$ ca. 1,0 mm larg., na base ou no meio dos ramos, às vezes no alto dos pedúnculos, glabrescentes ou ápice pouco piloso; bractéolas $0,8-2,3 \times \mathrm{ca}$. $0,4 \mathrm{~mm}$, em geral lineares, ápice piloso-ferrugíneo a glabrescente na frutificação; botões estaminados 2,8-3,8 x 1,5-1,8 $\mathrm{mm}$, glabros, atenuados na base, ápice arredondado; flores estaminadas 4,5-5,5 x 2,8-3,5 mm, campanuladas a afuniladas, estreitadas no ápice, verde-amareladas, em geral glabras, ápice papiloso, amarelado-claro quando seco; estames 7-10, salientes até $2,0 \mathrm{~mm}$; botões pistilados $1,3-1,8 \times$ ca. $1,0 \mathrm{~mm}$; flores pistiladas 2,6-3,0 x 1,4-2,0 mm, glabras, ápice pouco papiloso, estaminódios $6-9$, estigma saliente até 1,3 mm; Infrutescências 5,2-5,5 x ca. 3,2 cm, glabras; pedúnculos 3,4-4,6 cm compr., ramos alternos em geral aglomerados, ou subopostos pouco patentes os mais desenvolvidos; antocarpos oblongos a elipsoides, 8,5-12,5 x 3,0-5,5 mm, normalmente glabros, vermelhos a negros quando maduros; coroa ereta ou fechada, 0,8-1,1 $\mathrm{mm}$ altura; estigma saliente ca. $0,5 \mathrm{~mm}$.

Netto (1866a) ao descrever Guapira campestris indicou que o material utilizado na descrição estaria depositado no herbário Delessert em $\mathrm{P}$, contudo como - mesmo não foi localizado, a espécie foi lectotipificada com base no espécime Gardner 2944 que inclui flores estaminadas e a descrição original inclui apenas estas. O outro síntipo, Gardner 2715 possui ramos separados com flores estaminadas e pistiladas. Na descrição original Netto (1866a) comenta que há semelhança entre as folhas de $G$. campestris com as de $P$. caparrosa Netto $(=N$. theifera Oerst.), mas que a primeira diferencia-se pelos estames salientes. Vegetativamente as duas espécies são bem semelhantes e no herbário $\mathrm{K}$ há duas exsicatas de Gardner 2944. Em uma delas, um espécime de Gardner 2944 foi montado na mesma cartolina um exemplar de Glaziou 20434 identificado como Neea theifera. Apesar de ambas as espécies apresentarem, folhas glabras ou subglabras, podem ser distintas pois $G$. campestris apresenta inflorescências com ramos primários alternos a subopostos, sempre oblíquos e até quase adnatos ao pedúnculo, ao passo que $N$. theifera possui inflorescências com ramos em geral opostos e patentes.

A espécie mais semelhante com $G$. campestris é G. graciliflora, pois as folhas jovens da segunda espécie se parecem com as folhas jovens de plantas ananizadas de G. campestris. G. graciliflora diferenciase pelas folhas adultas com base obtusa a arredondada, atenuada no pecíolo, e pelas inflorescências mais delicadas com ramos patentes e normalmente pubérulo-ferrugíneas.

As populações de $G$. campestris podem apresentar grande variação morfológica. As plantas adultas e de maior porte, apresentam as folhas elípticas, ovadoelípticas a oblongas, de base cordada e margem inteira, ao passo que as plantas ananizadas apresentam no mesmo ramo folhas lanceoladas de base aguda e ovadas de base cordada, quase sempre com contorno foliar crenulado acompanhando a junção das nervuras principais. Também foi observada numa planta ananizada (G.Argent et al. 6533) a ocorrência de uma flor pistilada no mesmo aglomerado de flores estaminadas. Provavelmente estas anomalias são decorrentes da condição estressante do bioma Cerrado e das frequentes queimadas.

O material-tipo de Pisonia humilis, Glaziou 21960 e outros materiais examinados da mesma região apresentaram restos de caules com sinais de queimada, mas pelas folhas, flores e inflorescências foi possível identifica-los como sendo G. campestris, sendo realizada a sua sinonimização nesse trabalho.

Distribuição geográfica e habitats (Fig. 10): Guapira campestris ocorre apenas nas regiões CentroOeste e Nordeste do Brasil, em cerrados.

Material examinado: Brasil. Distrito Federal: Brasília, H.S. Irwin e T.R. Soderstrom 5987, 4.IX.1964, fl.pist., (UB); idem 8340, 15.IX.1965, fr. (UB); idem, B.A.S. Pereira et al. 2573, 21.IX.1993, fl.est. (HRCB); Planaltina, H.S. Irwin et al. 8908, 3.X.1965, fr. (UB). Goiás: Caiapônia, H.S. Irwin e T.R. Soderstron 7061, 19.X.1964, fr. (HB, MBM); Chapada dos Veadeiros, De Haas Sr. et al. 270 e 271, 24.IX.1967, fr. (HB). Mato Grosso: Gal. Caemeiro, T. Hartmann 381, VII.1963, fr. (SP); Xavantina, G. Argent et al. 6533, 26.IX.1967, fl. est. (K, P, RB, UB); idem, H.S. Irwin \& T.R. Soderstrom 6680, 9.X.1964, fr. (HB, MBM). Piauí: Paranaguá, Gardner 2715, VIII-IX.1839, fl. est./pist. (BM, K, parte do síntipo de P. campestris Netto). 


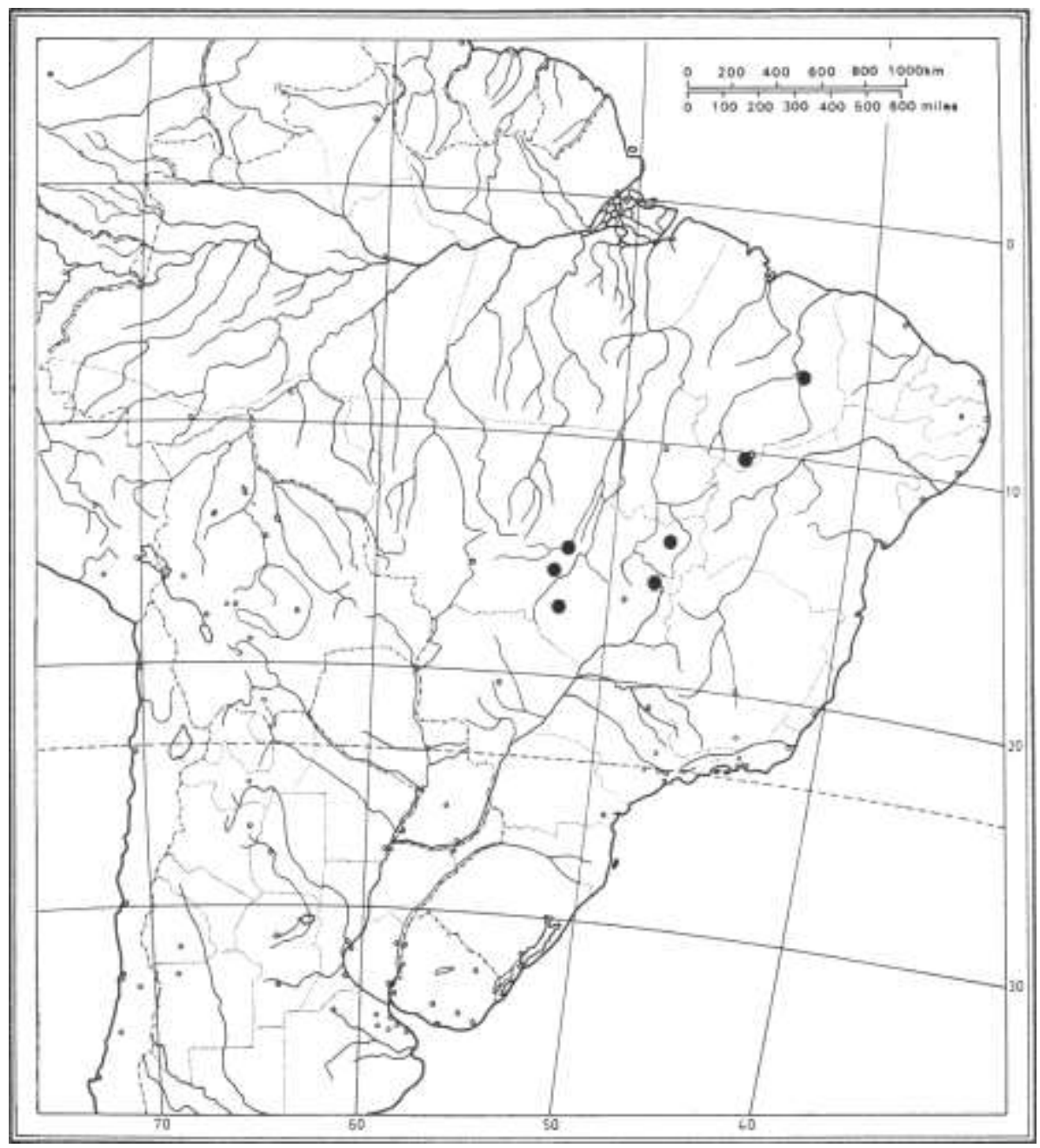

Fig. 10 - Distribuição geográfica de Guapira campestris.

1.3. Guapira graciliflora (Mart. ex J.A.Schmidt) Lundell, Wrightia 4(2): 81. 1968. I Pisonia graciliflora Mart. ex J.A.Schmidt in Mart., FI. Bras. 14(2): 358. 1872. $\equiv$ Torrubia graciliflora (Mart. ex J. A. Schmidt) Standl., Contr. U. S. Natn. Herb. 18(3): 100. 1916. Tipo: Brasil, "Cachoeira, prov. Bahiensis", XII.1818, fl. pist., Martius 2026 (lectótipo M!, isolectótipo M! 2 exs., aqui designado).

= Pisonia graciliflora var. subferruginosa Mart. ex J.A.Schmidt in Mart., FI. Bras. 14(2): 358. 1872, p.p.. Tipo: Brasil, Minas Gerais, Diamantina "Tejuco", fl. pist., Burchell 5800 (lectótipo K!, aqui designado).

Fig. 11

Nome vulgar: pau-piranha (Noberto 177, Ana Lima 25-67)

Arbustos, arvoretas ou árvores, 0,3-8,0 m alt., às vezes rebrotando de sistemas subterrâneos, frequentemente muito ramificados, caule $5,0-20,0 \mathrm{~cm}$ diam., córtex pouco fissurado quase liso; ramos velhos lenhosos, cilíndricos, geralmente retos ou quase retos, dicotômicos, 1,0-4,0 mm espessura, córtex cinza a creme-sujo, glabros, estriados, pouco ou não compressos quando secos; ramos novos verdeferrugíneos a vináceos, às vezes tricotômicos, ápices geralmente folhosos, tricomas esparsos ou condensados, quando secos negros a ferrugíneos, subquadrangulares; entrenós 1,2-5,5 cm compr., nos ramos novos $0,2-1,0 \mathrm{~cm}$ compr., geralmente 2 , raro 3 , entre as ramificações; cicatrizes foliares 1,0-2,0 mm diâm., pouco salientes; gemas até 2,0 mm diam., pubérulas, ferrugíneo-avermelhadas. Folhas com pecíolo 1,0-7,0 $\mathrm{mm}$ compr., subalado, geralmente pouco piloso. Laminas adultas $6,5-9,8 \times 3,3-5,6 \mathrm{~cm}$, elípticas a oblongo-elípticas, raramente suborbiculares, ligeiramente obovadas, base aguda, obtusa a arredondada, atenuada até a base do pecíolo, ápice obtuso a arredondado, às vezes agudo largo, às vezes curto-acuminado, geralmente de contorno regular, esverdeada escura, mais clara embaixo, às vezes glaucas, glabras ou pubéruloferrugíneas embaixo, especialmente nas nervuras; quando secas marrom claro, raramente verdeolivácea, às vezes preta ou parda com nervuras 


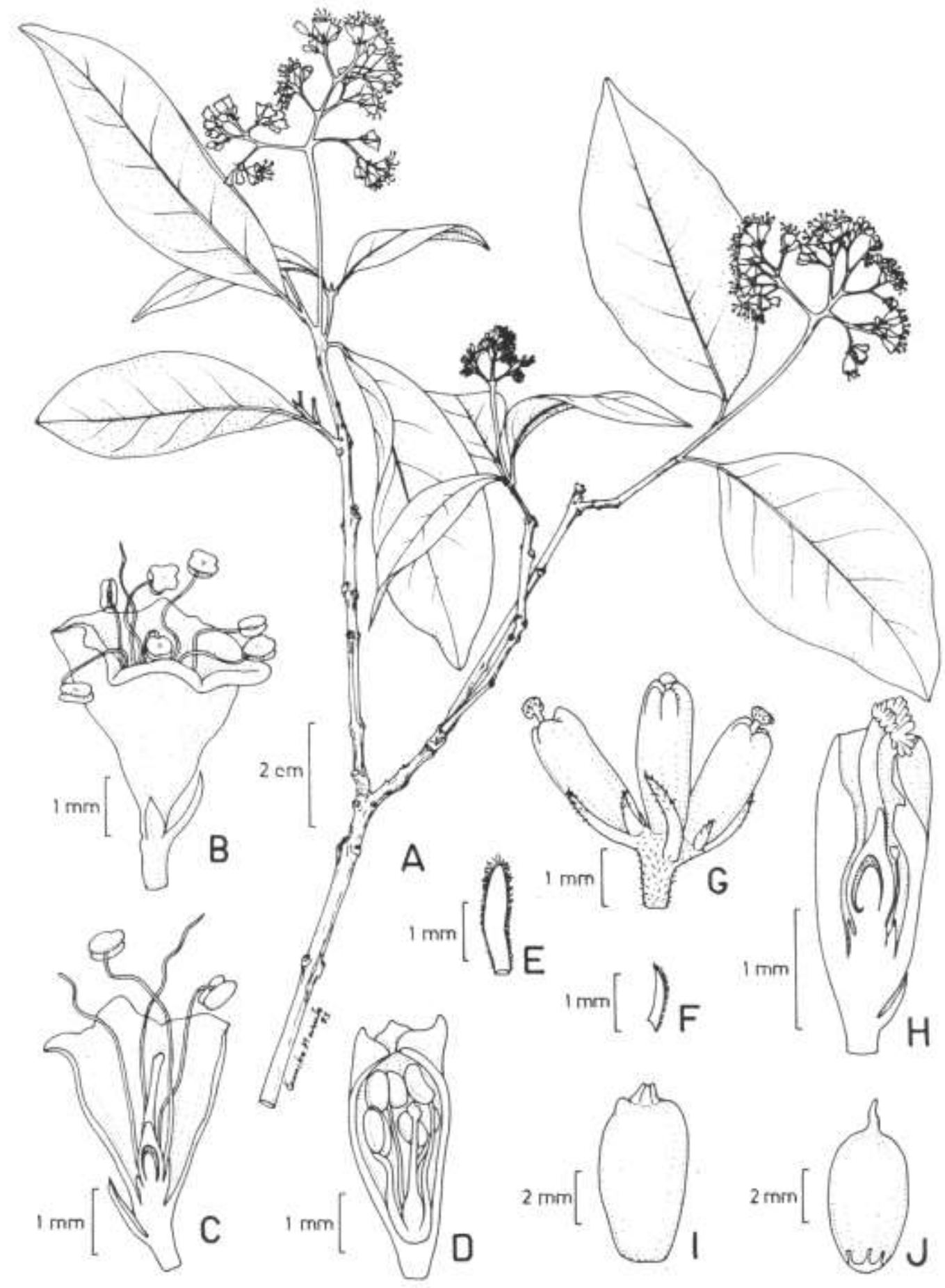

Fig. 11 - Guapira graciliflora: A. Ramo de planta masculina. B. Flor estaminada. C. Flor estaminada em corte longitudinal mostrando pistilódios com óvulo não funcional D. Botão estaminado em corte longitudinal. E. Bráctea da inflorescência pistilada, face ventral. F. Bractéola das flores pistiladas, face ventral. G. Cimeira terminal pistilada mostrando brácteas, bractéolas, botões e flores. H. Flor pistilada em corte longitudinal. I. Antocarpo com a coroa fechada. J. Fruto, base com estaminódios não desenvolvidos. (A - M.C. Silva Jr. et al. 588; B-D - D.C. Zappi et al. CFCR 8367; E-H - I. Cordeiro et al. CFCR 10111; I-J - M.L.M. Azevedo e A.L. Brochado 66). 
claras, membranáceas a cartáceas, pouco flexíveis, pouco brilhantes em cima, opacas embaixo, nervuras salientes nas duas faces, em geral reticuladas; as novas 5,2-10,3 cm compr., 1,4-4,4 cm larg., opostas nos nós medianos, verticiladas no nó apical, lanceoladas, elípticas a elíptico-lanceoladas, às vezes ligeiramente obovadas, raramente orbiculares as menores, base aguda a frequentemente arredondada, atenuada até a base do pecíolo, ápice agudo curto acuminado, raramente obtuso, quase sempre de contornos regulares, geralmente equiláteras, em cima glabras, embaixo glabrescentes exceto nervuras e margens, as muito novas totalmente pubéruloferrugíneas embaixo, geralmente tricomas curtos, adpressos; quando secas membranáceas flexíveis, discolores ou não, marrom enegrecido, mais claras embaixo, em cima pouco brilhantes ou opacas, embaixo opacas, nervuras não salientes ou pouco salientes embaixo. Inflorescências 4,6-10,5 x 3,5-6,8 $\mathrm{cm}$, as pistiladas menores, ca. $2,8 \times 2,3 \mathrm{~cm}$, verdeamareladas a ferrugíneas, terminais em ramos curtos gemados ou folhosos, geralmente pubéruloferrugíneas, glabrescentes, ligeiramente perfumadas; pedúnculo 1,0 4,5 cm compr., ramos primários opostos ou subopostos normalmente patentes, ramos secundários verticilados a sub-verticilados, geralmente delgados 0,2-0,5 mm espessura; cimeiras terminais usualmente com ramos laterais desenvolvidos até 1,5 $\mathrm{mm}$ compr.; brácteas 1,0-2,5 mm compr., deltoidelineares a oblongo-lineares, na base das címulas, raramente no meio dos ramos secundários, franjado-ferrugíneas, tricomas apicais mais longos; bractéolas 0,6-1,2 $\mathrm{mm}$ compr., lineares, tricomas esparsos ou mais concentrados no ápice, decíduas na frutificação; botões estaminados 2,5-3,5 x 1,0-1,5 mm, curto-clavados, geralmente bem estreitados da base até a região mediana, frequentemente com células com ráfides evidentes no cálice; flores estaminadas 3,5-4,5 x 2,0-3,0 mm, afuniladas, base estreitada, verdes a verde-avermelhadas, levemente perfumadas, glabras ou base ferrugínea; estames 5-9, salientes até 3,0 mm, filete creme, anteras 0,2-0,3 mm compr., creme; botões pistilados 1,5-2,0 mm compr., 0,3-0,7 mm larg., margem apical papilosa; flores pistiladas 2,0-3,0 x 0,6-1,8 mm, tubulosas, verdes, às vezes ápice róseo, estigma em geral pouco saliente, raro até $1,5 \mathrm{~mm}$. Infrutescências 4,8-5,8 $\mathrm{x}$ 3,1-4,8 cm, pedúnculos 2,8-3,2 cm compr.; antocarpos 6,0-10,0 x 3,0-5,0 mm, elipsoides, geralmente truncados na base e no ápice, os imaturos verdes e frequentemente costados, os maduros roxo-escuro a negros, brilhantes; coroa fechada, imersa ou até $0,5 \mathrm{~mm}$ alt., estigma apenas visível ou saliente até $0,5 \mathrm{~mm}$.
Schmidt (1872) ao descrever Pisonia graciliflora se baseou especialmente no manuscrito de Martius no Herbário $M$, citado como Martius s.n. além dos espécimes de Burchell 7530 e 7924 coletados em Goiás. Das três exsicatas da coleção Martius 2026 no herbário de Munique, todas anotadas como "Pisonia graciliflora Mart foi escolhida como lectótipo aquela onde consta uma breve descrição manuscrita de Martius, e com dados mais completos do local de coleta.

Pisonia graciliflora var. subferruginosa foi proposta por Schmidt (1872) com base no manuscrito e no material de Martius s.n. da Bahia, e mais quatro outros síntipos, sendo três espécimes coletados em Minas Gerais e um no Rio de Janeiro. Para esse trabalho foram examinados além do material de Martius, mais dois síntipos. No Herbário de Munique o material Martius 2026 é composto de três exsicatas, todas com flores pistiladas. $O$ exame desses espécimes mostrou que os mesmos pertenciam a espécie Guapira opposita, e sob essa espécie, parte da variedade foi sinonimizada. O sintipo Burchell 5800 , tem as características apresentadas na descrição da variedade e não se diferencia de $G$. graciliflora. No herbário de Kew o material Burchell 5800 está colocado numa mesma exsicata com Burchell 7530, síntipo de $P$. graciliflora var. graciliflora.

Os espécimes de Guapira graciliflora em geral estão identificados corretamente nos herbários. A espécie que mais se assemelha é G. noxia, pelo tipo similar de inflorescência, mas ambas podem ser assim diferenciadas: $G$. graciliflora inclui plantas mais delicadas e mais ramificadas, com ramos distais delgados e quase sem córtex, em geral retos, folhas frequentemente lanceoladas e com gemas, flores estaminadas e anteras menores, enquanto $G$. noxia além de ter essas estruturas maiores, é mais robusta, com ramos distais espessados e corticados, em geral tortuosos e folhas geralmente orbiculares ou oblongas. G. graciliflora também tem semelhanças com $G$. opposita e com G. campestris, mas diferencia-se facilmente da primeira espécie especialmente pelas inflorescências, com ramos opostos e não verticilados, e de G. campestris, por essa ter as folhas sésseis de base cordada, com margem regularmente subcrenuladas, acompanhando as junções das nervuras, característica muito rara em G. graciliflora.

Distribuição geográfica e habitats (Fig. 12): G. graciliflora ocorre em diversos estados do Brasil, predominantemente nas vegetações de cerrado, cerradão, matas secas e eventualmente em matas ciliares. As plantas que ocorrem em cerrados sujeitos a fogo florescem rapidamente, às vezes tendo apenas $30 \mathrm{~cm}$ de altura. 


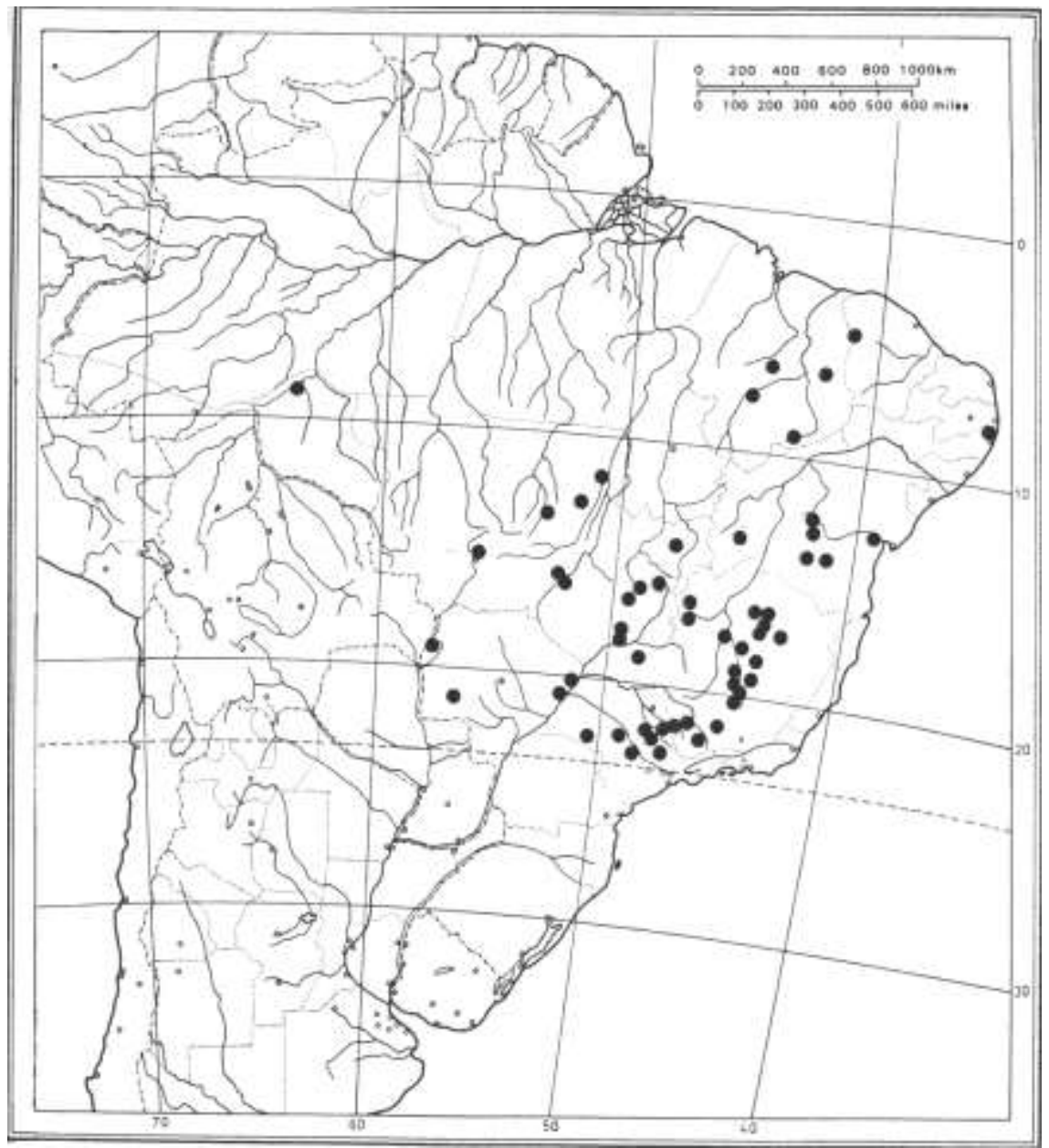

Fig. 12 - Distribuição geográfica de Guapira graciliflora.

Material selecionado: Brasil. Bahia: Correntina, R.C. Mendonca et al 1573, 17.X.1989, fr. (CEN, IBGE, SP); Rio de Contas, R.M. Harley et al. 918, 6.XI.1988, fl. masc. (HRCB, K, SPF). Ceará: Chapada de Ibiapaba, $A$. Fernandes e Matos s.n., 16.I.1982, fr. (TEPB 11095, SPF). Distrito Federal: Brasília, D. Alvarenga 416, 13.IX.1989, fl. masc. (HRCB, IBGE, UEC); Contagem, E.P. Heringer 15621, 9.IX.1976, fl. fem/fr. (IBGE, MBM, SP, UEC). Goiás: Aragarças, R.M. Harley et al. 10846, 26.X.1968, fr. (K, P UB); Chapada dos Veadeiros, H.S. Irwin et al. 9309, 19.X.1965, fr. (MBM, UB). Maranhão: Parque Estadual de Mirador, F. Noberto et al. 177, 27.IX.1988, fr. (MG). Minas Gerais: Botumirim, R. Mello-Silva et al. 730 e 731 , 20.XI.1992, fr. (K, SPF); Uberlândia, G.M. Araujo 33, 24.X.1986, fl. masc. (HUFU, SPF). Mato Grosso, Barra do Garças, G. Eiten e L. Eiten 8893, 21.IX.1968, fl. fem. (K, SP, UB). Mato Grosso do Sul: Selviria, J.Y. Tamashiro et al. 134, 6.XI.1985, fl. masc. (CEN, HRCB, SP, UB, UEC). Pernambuco: Pontas de Pedra, Andrade Lima 25-67, 21.XII.1967, fl. masc. (IPA, SPF). Piauí: Ribeiro Gonçalves, A. Fernandes et al. s.n., 4.IX.1981, fl. masc. (TEPB 2167). Rondônia: Porto Velho, B. Maguirre et al. 56606, 9.IX.1963, bot.masc. (MG). São Paulo: São Carlos, G. Eiten 3383, 29.XI.1961, fr. (HRCB, SP, UB).
1.4. Guapira hirsuta (Choisy) Lundell, Wrightia 4(2): 81. 1968. इ Pisonia hirsuta Choisy in DC., Prodr. 13(2): 445. 1849. $\equiv$ Torrubia hirsuta (Choisy) Standl., Contr. U.S. Natn. Herb. 18(3): 100. 1916. Tipo: Brasil, "Bahia, Poço d'Areia, prope Jacobin", s.d., fl. est., Blanchet 3864 (holótipo P!; isótipos BM!, BR!)

= Pisonia warmingii Heimerl, Vidensk. Meddr. dansk naturh. Foren 1890: 162. 1891. I Torrubia warmingii (Heimerl) Standl., Field Mus. Nat. Hist. Bot. 8(5): 308. 1931. I Guapira warmingii (Heimerl) Lundell, Wrightia 4(2): 84. 1968. I Guapira opposita var. warmingii (Heimerl) Reitz, Flora llustrada Catarinense Nictaginaceas: 37. 1970. Tipo: Brasil, Rio de Janeiro, A.Glaziou 11414, s.d., estéril (holótipo P!). Syn.nov.

$=$ Torrubia asperula Standl., Field Mus. Nat. Hist. Bot. 17(3): 242. 1937. इ Guapira asperula (Standl.) Lundell, Wrightia 4(2): 80. 1968. Tipo: Brasil, Santa Catarina, Parati, 25.X.1928, fl. est., F.C. Hoehne 23182 (holótipo F n.v.; isótipo SP!). Syn. nov.

Fig. 13

Nome vulgar: "caixeta" (Toledo f. , SPSF 14674). 

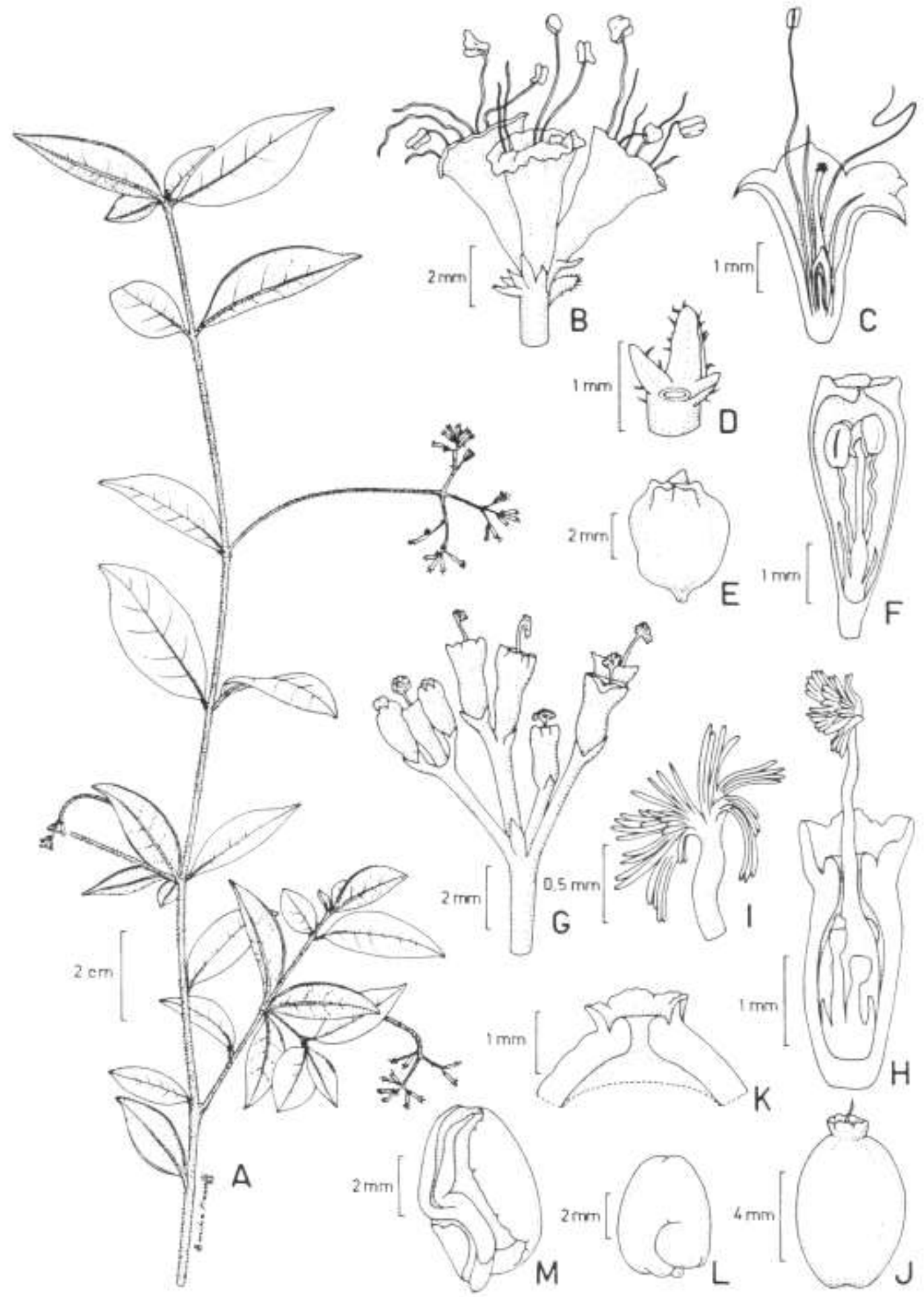

Fig. 13 - Guapira hirsuta: A. Ramo de planta feminina. B. Cimeira terminal estaminada. C. Flor estaminada em corte longitudinal. D. Bráctea e bractéolas da base das flores. E. Botão estaminado galhado, semelhante a flor de Neea, mas com ápice truncado. F. Botão estaminado com perianto em corte longitudinal, mostrando filetes sinuosos e anteras com deiscência lateral. G. Ramo distal de uma inflorescência pistilada. H. Flor pistilada com o perianto em corte longitudinal. I. Detalhe do estigma penicelado. J. Antocarpo com coroa aberta. K. Detalhe da coroa do antocarpo. L. Embrião em vista dorsal. M. Embrião em corte longitudinal. (A - J.R. Pirani et al. 1996; B, D - R. Kumrow et al. 2332; C, E-F - A. Furlan et al. CFSC 6744; O-1 - Reitz \& Klein 5672; J-M - A. Furlan et al. 45). 
Arbustos, subarbustos ou árvores, 1,5-9,0 m alt., caule 3,0-4,0 cm diam.; ramos adultos lenhosos, cilíndricos, retos, raro curvos, pouco delgados, geralmente alongados, lenticelados, glabros a pubérulos os do alto; ramos novos em geral bem folhosos, delgados, até $2,5 \mathrm{~mm}$ espessura, às vezes enrugados e estriados quando secos, pubérulos a usualmente hírtulos, tricomas amarelados a marrons, às vezes pouco ferrugíneos; entrenós $0,5-6,8 \mathrm{~cm}$ compr., geralmente apenas 2 entre as ramificações; cicatrizes 0,8-2,0 $\mathrm{mm}$ larg., cordiformes sulcadas; gemas 0,5-1,5 mm diam., ferrugíneo-claras a marrons, geralmente uma, raramente duas acima de cada cicatriz. Folhas com pecíolo 3-13 mm compr., verdevináceos, piloso-hírtulo no dorso e nas laterais, os novos totalmente hírtulos, canaliculados quando secos. Laminas adultas 4,2-11,5 x 1,5-5,2 cm, elípticolanceoladas, lanceoladas, ou elípticas, às vezes as mais velhas ligeiramente obovadas, base aguda ou aguda larga quase obtusa, pouco atenuada, ápice agudo a obtuso, curto ou raramente largo-acuminado, acúmen em geral agudo, margem inteiras, pouco ou não revolutas; pares desiguais ou pouco desiguais, opostos, verticilados nos nós ramificados; em cima glabra exceto a base da nervura mediana, ou poucos tricomas curtos esparsos, às vezes apenas a base dos tricomas tornando-se ligeiramente áspera, embaixo tricomas esparsos, mais concentrados ao lado da nervura mediana, sem domácias; quando seca membranácea firme, em cima ligeiramente áspera, pouco brilhante, marrom ou parda, nervuras pouco ou não salientes, embaixo tomentosas macias, opacas, pouco mais clara; folhas novas usualmente lanceoladas, base aguda, ápice agudo às vezes longo acuminado, a menor do par elíptico-obovada de ápice obtuso curto-acuminado, frequentemente congestas nos ápices dos ramos usualmente hírtulo-tomentosas nas duas faces; quando secas geralmente ferrugíneopardas em ambas faces, às vezes negras em cima com pouco tricomas especialmente sobre as nervuras e marrons embaixo, pilosidade mais clara bem evidente ao lado da nervura mediana; tricomas ca. 0,3 $\mathrm{mm}$ compr., base ereta unisseriada amarelo-clara, célula apical oblíqua, alongada, amarelado-escura a marrom. Inflorescências 5,5-10,5 x 2,3-7,5 cm, axilares ou terminais em ramos curtos pilosos, desenvolvidos até $2,5 \mathrm{~mm}$, eretas ou pêndulas, verticiladas a subverticiladas, raramente as maiores com um ramo alterno oblíquo e depois verticiladas, em geral hírtula laxa, raramente densa; pedúnculo 1,8-6,4 cm compr., hírtulo denso ou esparso, ramos pulverulentos ou tricomas hírtulos mais concentrados nas junções; ramos finais às vezes capiláceos glabrescentes, cimeiras terminais trímeras ou 7-9 flores aglomeradas, às vezes flores isoladas nos ramos distais; brácteas 1,3-2,5 mm compr., lineares, frequentemente no meio dos ramos secundários e base das címulas, às vezes também nos ramos primários, pilosas no dorso, especialmente nas margens e no ápice; bractéolas de 0,5-1,2 mm compr., deltoide-lineares, glabras ou pilosas nas margens; botões estaminados 2,6-4,0 x 1,2-2,0 mm, clavados, cálice delgado, verde- arroxeado, pouco pulverulento ou tricomas esparsos na base; flores estaminadas 2,8-4,8 x 2,1-3,2 mm, campanulada aberta, poucos tricomas ferrugíneos na base; estames 6 a 10, alvos, salientes até $5,0 \mathrm{~mm}$; botões pistilados 1,5-2,5 x 0,7-1,0 mm, cilíndricos, em geral glabros ou esparso-pilosos; flores pistiladas 2,0$3,8 \times 1,0-2,0 \mathrm{~mm}$, tubulosa-cilíndrica, glabra ou poucos tricomas esparsos; estigma saliente até $1,8 \mathrm{~mm}$. Infrutescências 5,9-12,8 x 4,4-9,4 cm, verticiladas, em geral pêndulas; pedúnculo 2,8-9,5 cm compr., pouco hírtulo, ramos distais espessados; antocarpos 7-9 × 3$5 \mathrm{~mm}$, elipsoides alongados, atenuados na base, vináceos, glabros ou pouco hírtulos; coroa aberta, ca. $1,0 \mathrm{~mm}$ alt., normalmente hírtula externamente, bem reflexa e ondulada.

Guapira hirsuta é uma espécie muito característica especialmente pelas inflorescências verticiladas e densa pilosidade castanha na face inferior das folhas. Apesar desse fato, alguns táxons do gênero foram relacionadas com ela. As descrições originais de Pisonia hirsuta e de P. pubescens H.B.K. sugerem que as mesma são muito próximas ou até coespecíficas. $O$ exame do material-tipo de $P$. pubescens coletado por Bonpland 813 (P!), próximo ao rio Apures na Venezuela, mostrou que se trata apenas de um ramo empobrecido, porém suficiente para inclui-lo em Guapira, como já proposto por Lundell (1968). Porém, é bem diferente de G. hirsuta pela inflorescência não verticilada e pelas folhas obovadas de base e ápice arredondados. Portanto, as duas espécies são distintas morfologicamente, sendo Guapira hirsuta restrita ao Brasil e G. pubescens (H.B.K.) Lundell extra-brasileira. O holótipo de Pisonia warmingii é um espécime estéril, que foi coletado por Glaziou 11414 no Rio de Janeiro. Apesar dessa situação, o holótipo depositado em Paris, é idêntico ao material-tipo de $P$. hirsuta, tendo sido sinonimizado nesse trabalho. Torrubia asperula foi descrita a partir do material Hoehne 23182, de Santa Catarina. A análise do isótipo mostrou que a superfície foliar é ligeiramente áspera devido aos tricomas que são decíduos, mas nessa e em todas as outras características, o espécime pode ser incluído dentro da variabilidade da espécie.

Barth \& Barbosa (1972) estudaram os grãos de pólem de espécimes identificados como Guapira asperula e como $G$. opposita var. warmingii, táxons sinonimizados nesse trabalho sob G. hirsuta. Para $G$. opposita var. warmingii as autoras encontraram grãos 3-colpados com muitos espículos longos enquanto para G. asperula grãos 3 ou 4-colpados com poucos espículos pequenos. É possível que a divergência obtida possa ser explicada porque foram analisados 25 grãos de uma única exsicata, de cada táxon e essa diferença seja parte da variação da espécie. Para reforço dessa argumentação, há uma sobreposição em relação aos tamanho dos grãos, que variam de 34,0-48,0 $\mu$ de diâmetro em $G$. asperula e de 31,5$50,5 \mu$ de diâmetro em $G$. opposita var. warmingii. Sendo portanto mantida as sinonímias aqui propsotas em relação a $G$. hirsuta. 
Outras duas espécies que podem ser relacionadas com $G$. hirsuta são $G$. tomentosa e $G$. noxia. G. hirsuta diferencia-se de $G$. tomentosa por essa última apresentar inflorescência aglomerada capituliforme e folhas com margens bem revolutas. $G$. hirsuta geralmente apresenta na face inferior das folhas, os tricomas aglomerados pelo ápice, com a célula apical amarelada a marrom, simulando tricomas estrelados invertidos, e semelhantes aos que ocorrem em G. noxia, porém, nessa espécie a célula apical é ferrugínea a avermelhada.

De todos os espécimes examinados de $G$. hirsuta, o mais divergente é Gomes 1772 (HRCB), da ilha de Trindade, Espírito Santo, por ter as folhas obovais e obtusas, curto-acuminadas, ao invés das folhas lanceoladas típicas da espécie. Contudo a inflorescência verticilada e a densa pilosidade castanha na face inferior da folha permitem identificalo como pertencente a essa espécie.

Distribuição geográfica (Fig. 14): Ocorre no Pará, na maioria dos estados do Nordeste, todos os estados do Sudeste, e no Sul até Santa Catarina, com poucos registros em Goiás, Mato Grosso do Sul, Fora do Brasil ocorre também no Paraguai.
Material selecionado: Brasil. Alagoas: Mata Grande, Andrade Lima 74-7777, 20.XII.1974, fl. est. (IPA). Bahia: Cachoeira, L. Scardino et al. GPC 954, XI.1980, fl. pist. (ALCB, HRB, HUEFS, IPA, SPF); Seabra, J.R. Pirani et al. 1996, 13.II.1987, fl. pist. (K, SPF). Ceará: Serra Maranguape, Andrade-Lima 55-2393, 24.XI.1955, fl. est. (IPA, SPF). Espírito Santo: São Mateus, G. Hatschbach et al. 60076, 10.XI.1993, fl. est. (MBM, SPF). Goiás: Goiânia, J.A. Rizzo A Barbosa 2531, 5.X.1968, bot. masc. (UFG). Maranhão: Alzilândia, J. Jangoux e R.P. Bahia 341, 11.XII.1978, fr. (MG). Mato Grosso do Sul: Corumbá, J.A. Ratter et al. 5115, 7.X.1985, fl. pist. (UB). Minas Gerais: Caratinga, L.V. Costa et al. 243, 30.XI.1987, fl. est. (BHCB); Santana do Riacho, A. Furlan et al. CFSC 6744, 8.XI.1980, fl. est. (SPF). Pará: Altamira, A.T.G. Dias 394, 20.X.1986, fl. est. (MG); Monte Alegre, R. L. Froes 30436, 28.IX.1953, fl. est. (UB). Paraíba: Areia, J.C. Moraes s.n., 17.VII.1953, fl. pist./fr. (SPSF 4101, SPF). Paraná: Guaraquecaba, G. Hatschbach et al. 54917, 23.I.91, fl. est. (MBM). Rio de Janeiro: Rio de Janeiro, $Z$. Trinta et al. 1391, 13.ll.1968, fl. est. (R); Tingua, $A$. Glaziou 9560, 12.X.1878, fl. pist. (K, P). Rio Grande do Sul: Tones, J. Lindeman et at s.n., 13.VII.1972, fl. pist./fr. (ICN 27842). Santa Catarina: Joinville, Reitz e Klein 5672, 8.XI.1957, fl. est. (HB, HRCB, PEL). São Paulo: Águas da Prata, D.V.Toledo f. s.n., 19.11.90, fr. (SPSF 14674); llha do Cardoso, G.J. Shepherd \& D.M. Vital 11226, 12.I.1977, fl. est. (MG, UEC).

Paraguai. Alto Paraná: K. Fiebrig 6302, 1910, fr. (G).

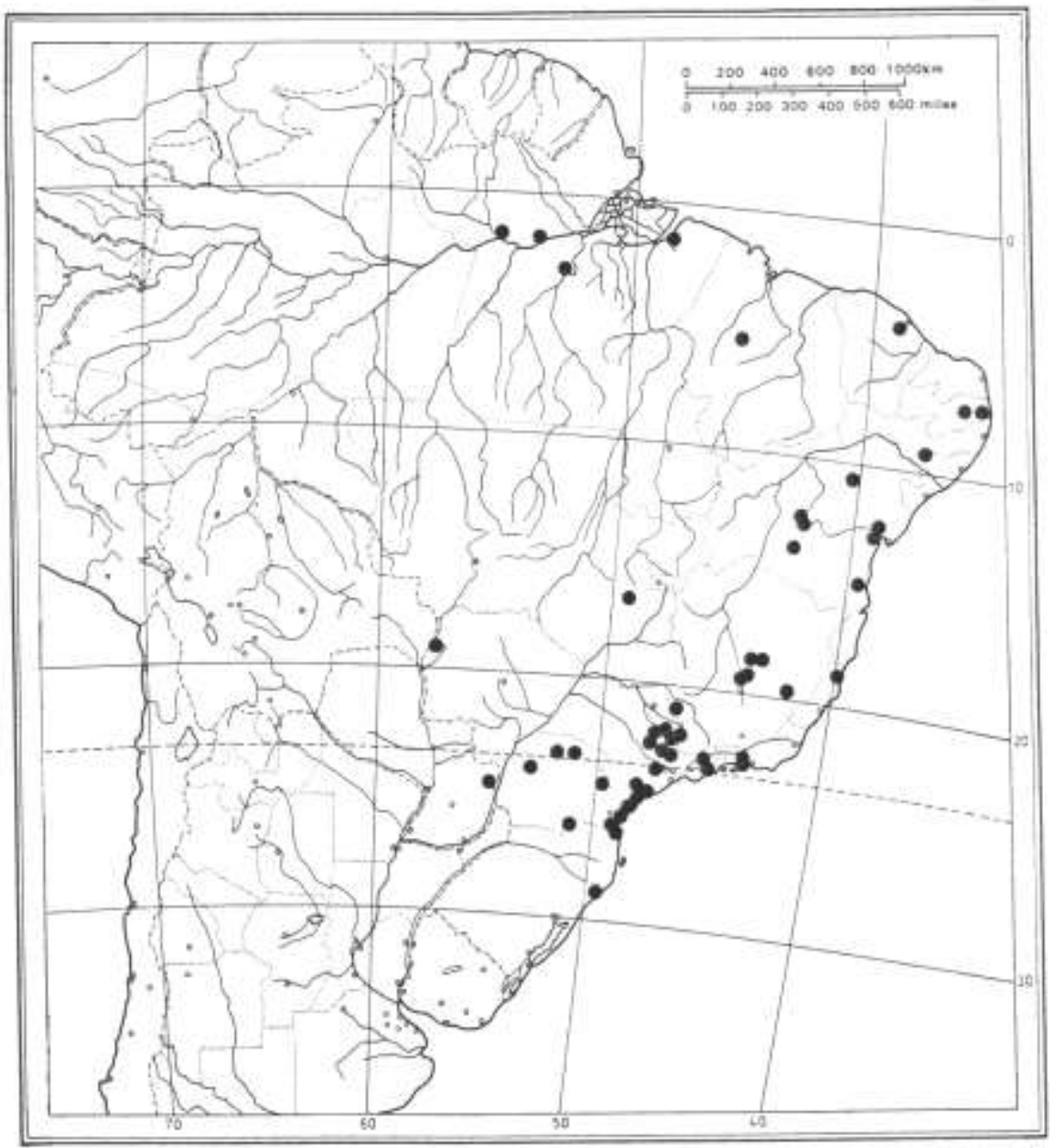

Fig. 14 - Distribuição geográfica de Guapira hirsuta. 
1.5. Guapira laxa (Netto) Furlan $\equiv$ Pisonia laxa Netto, Ann. Sci. nat. 5a ser. Bot. 5: 84. 1866. Tipo: Brasil, "In limite Provinciarum Minas Geraes et Goyaz, loco dicto Olho d'Agua", 1816-1821, A Saint-Hilaire s.n., fr. (holótipo P!). comb.nov.

= Pisonia psammophila Mart. ex J.A. Schmidt in Mart., FI. Bras. 14(2): 362. 1872. Tipo: Brasil, "in arenis maritimis prov. Bahiensis inter llheos et Camamu", I.1819, fl. est., Martius 2155 b (lectótipo M!). Syn. nov.

= Pisonia darwinii Hemsley, Rep. Challenger, Bot. 1(2): 20. 1885. Tipo: Brasil, Pernambuco, Fernando de Noronha, Darwin s.n. (holótipo n.v.). Syn. nov.

= Pisonia platystemon Heimerl, Vidensk. Meddr dansk naturh. Foren 1890: 161. 1891. Tipo: Rio de Janeiro, Magé, 10.IX.1868, fl. est., A. Glaziou 2897 (lectótipo P!, isolectótipos BR!, K!, aqui designados). Syn. nov.

Fig. 15

Nome vulgar: joão-mole ( $F$. Xavier s.n. JPB 605); pau-tapuia (L.P. Xavier S.n. JPB 509); pau-piranha (Acad. Bras. Ciências 1082); farinha-seca (Andrade Lima 61-3602); orelha-de-burro (Araujo 168).

Arbusto, arvoretas a árvores, 1,2-12,0 m alt., caule 7,0-34,0 cm diâm., marron; fuste 1,5-2,0 m alt., madeira fraca. Ramos adultos cilíndricos, tortuosos, glabros, exceto articulacões e ramos superiores pubérulo-ferrugíneos glabrescentes; córtex cinéreocreme, lenticelado; ramos novos retos, lenhosos, totalmente pubérulo-ferrugíneos, pouco ou não compressos quando secos; entrenós 0,9-6,0 cm compr., em geral 2 , raro 4 entre cada ramificacdo, às vezes vários aglomerados na base de uma ramificação, nós espessados; cicatrizes foliares hemiorbiculares a cordiformes sulcadas, até 2,2 mm larg.; gemas $0,6-1,8 \mathrm{~mm}$ totalmente pubérulo-ferrugíneas. Folhas com pecíolos $0,6-3,1 \mathrm{~cm}$ compr, totalmente ferrugíneos, os secos estriados no dorso e canaliculados em cima. Laminas 2,4-19,7 x 1,1-10,4 $\mathrm{cm}$, ovadas, elípticas, raramente obovadas, as novas frequentemente ovadas, orbiculares, base arredondada a obtusa, raramente aguda, ligeiramente atenuada, ápice obtuso, agudo a emarginado, às vezes curto-acuminado, membranáceas, as adultas glabras a esparsamente pilosas em cima, glabras a densamente ferrugíneo-tomentosas embaixo, um pouco menos nas nervuras secundárias, as novas ferrugíneo-tomentosas escuras nas duas faces; quando secas cartáceas quebradicas, em cima pretas, embaixo castanho-ferrugíneas exceto nas nervuras, muitas vezes as adultas esverdeadas, nervuras impressas embaixo e sem tricomas, pouco salientes em cima e com tricomas; tricomas ramificados. Inflorescências 2,8-8,9 x 1,8-4,8 cm, não verticiladas, terminais em ramos curtos gemados, aglomeradas nos ápices dos ramos ou saindo de ramos sem folhas, creme-esverdeadas a ferrugíneas; pedúnculo 0,9-5,8 $\mathrm{cm}$ compr., ramos primários alternos a opostos, oblíquos, flexíveis, os secundários variando de alternos a sub-verticilados, não bracteados; cimeiras terminais trímeras ou 6-12 flores aglomeradas, às vezes raceemiformes, brácteas até $2,5 \times$ ca. $0,5 \mathrm{~mm}$, linear-deltoides, na base do aglomerado de cimeiras jovens, decíduas, ferrugíneas no dorso; bractéolas 0,5-1,3 mm compr., deltoides, facilmente decíduas, côncavas, ápice agudo, dorso ferrugíneo, às vezes duas unidas; botões estaminados 1,5-3,5 x 1,0-2,0 $\mathrm{mm}$, obovados, clavado-obovados ou romboidais, ápice truncado a arredondado os menores, totalmente ferrugíneos; flores estaminadas 3,5-5,0 x 2,5-3,0 mm, campanuladas a afuniladas, totalmente amareloferrugíneas; lobos do cálice ligeiramente retangulares, eretos, pouco incisos; estames 6 a 9, salientes até 3,0 $\mathrm{mm}$; pistilódio ca. 3,0 mm compr., estipitado, incluso; botões pistilados clavados, 1,5-2,0 x 0,8-1,2 mm, ferrugíneos, ápice arredondado, estigma sinuoso; flores pistiladas 2,0-3,2 x ca. 1,0 mm, tubulosas, oblongas, ligeiramente estreitadas no meio, totalmente ferrugíneas, estaminódios 6-7, pouco desenvolvidos. Infrutescências 3,4-5,9 x 1,6-6,4 mm; pedúnculo 1,2$4,3 \mathrm{~mm}$, às vezes ramificado dicotomicamente perto da base; antocarpos 6,4-8,5 x 2,5-4,0 mm, oblongos, pouco carnosos, vináceos, glabrescentes, ligeiramente estriados quando secos, frequentemente atenuados no ápice; coroa fechada, ca. 0,5 mm alt., ligeiramente apiculada, pilosa-ferrugínea.

Guapira laxa é muito semelhante a G. noxia, diferenciando desta pela inflorescência com ramos oblíquos e não patentes, geralmente flexíveis e moles, pelas folhas novas ovais a oval-elípticas e em geral com ápice acuminado, e com as duas faces bem pilosas. Em G. noxia a inflorescência apresenta ramos patentes e inflexiveis, e as folhas novas em geral são elípticas de ápice obtuso a arredondado, pouco ou não pilosas na face superior.

A aceitação de $G$. laxa como espécie distinta e não como forma ou variedade de $G$. noxia, conforme sugerido por Heimerl $(1891,1934)$ e por Westra em etiquetas de herbário, provém do exame de numerosos exemplares, em especial aqueles com folhas novas, que mostraram ser bem diferentes dos exemplares de G. noxia. Além disso, G. laxa ocorre em caatinga e restingas (Fig. 16), enquanto $G$. noxia ocorre preferentemente em cerrado e campo rupestre (Fig. 20).

O lectótipo de P. psammophila, Martius $2155 b$ depositado em M, em nada difere de Guapira laxa, e por isso a espécie foi sinonimizada. Diferentemente, os outros dois parátipos incluídos em $P$. psammophila: Regnell III-1023 de Minas Gerais e Sellow 1407 de Brasil Meridional foram retirados dessa espécie e identificados como G. noxia.

Embora o espécime-tipo de Pisonia darwinii, coletado por Darwin em Fernando de Noronha não tenha sido aqui examinado, as excelentes descrição e ilustração do protólogo concordam perfeitamente com os demais materiais estudados de G. laxa, permitindo a sinonimização aqui proposta.

Pisonia platystemon foi descrita com base em dois sintipos, Glaziou 2897 e 11415, depositados no Herbário de Paris. A análise dos mesmos mostrou que podem ser incluídos dentro da variação de G. laxa. O espécime Glaziou 2897 selecionado como lectótipo da 


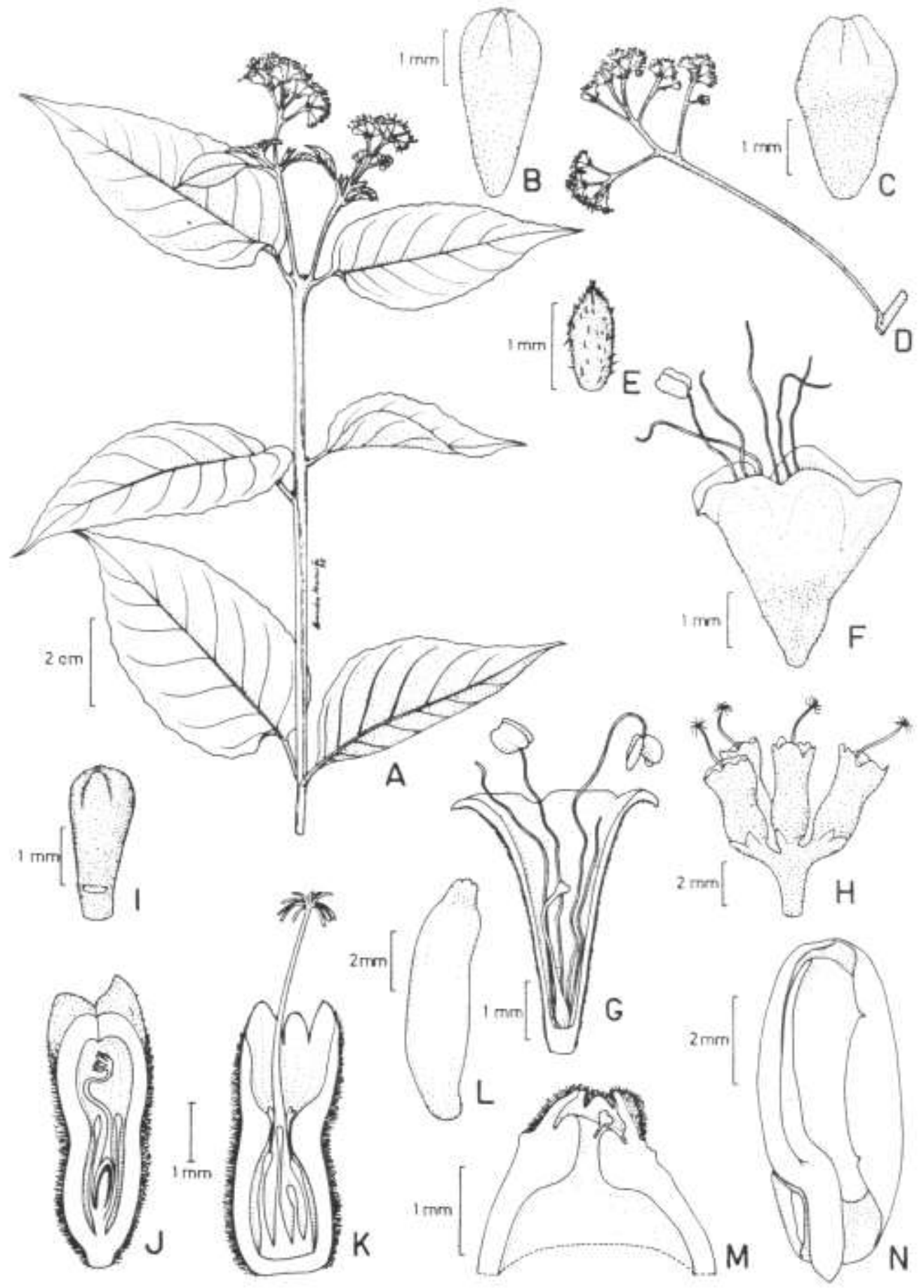

Fig. 15 - Guapira laxa: A. Ramo de planta masculina com folhas jovens. B. Botão estaminado de ápice arredondado. C. Botão estaminado com forma romboidal, ápice truncado. D. Inflorescência estaminada mais desenvolvida. E. Bractéola decídua, face dorsal. F. Flor estaminada. G. Flor estaminada, cálice em corte longitudinal. H. Cimeira terminal pistilada. I. Botão pistilado de ápice arredondado. J. Botão pistilado em corte longitudinal mostrando estilete sinuoso e ápice truncado. K. Flor pistilada, cálice em corte longitudinal. L. Antocarpo jovem. M. Detalhe do ápice do antocarpo. N. Embrião em corte longitudinal. (A - coletor anônimo HUEFS 3092; B-C, E-G - H.Z enaide 25; D - M.L.S. Guedes 862; H, J-K - T.S. Santos 923; I - O. Kouri Jr. 27 ; L - A. Araujo 105; M-N - J.E.M. Brazão 141). 
espécie, está também relacionado como um dos síntipos de $P$. obtusata var. rufescens Schmidt, nesse trabalho incluída na sinonimia de $G$. noxia (vide comentários nesta espécie). A coleta Glaziou 11415 apresenta etiquetas conflitantes: no herbário de Kew consta a coleta como sendo "Rio de Janeiro" enquanto que no herbário de Paris consta "Minas Gerais entre Sitio e Ilheus". Segundo Wurdack (1970) é comum a ocorrência de dados contraditorios em etiquetas de Glaziou.

Embora Lundell (1968) tenha feito 60 combinacões novas no gênero Guapira, os nomes Pisonia laxa, $P$. psammophila, $P$. darwinii e $P$. platystemon não foram transferidos para esse gênero.

Distribuição geográfica e habitats (Fig. 16): G. laxa ocorre no Brasil em área de caatinga e restingas do Nordeste e no norte de Minas Gerais. As referências para o Rio de Janeiro são apenas de dois espécimes coletados por A. Glaziou, de procedência duvidosa.

Material selecionado: Brasil. Bahia: Casa Nova, L.M.C. Gonçalves 217, 10.IX.1981, fl. masc. (HRB, RB); Santaluz, L.P. Queiroz 1132, 16.XI.1986, bot. masc. (HUEFS, SPF). Ceará: Santana do Cariri, A.L. Peixoto et al. 1644, 30.XII.1981, fl. fem./fr. (UEC). Minas Gerais: Contendas, Martius 1593, s.d., estéril (M). Paraíba: Areia, V.P.B. Fevereiro 74, 30.X.1980, bot. masc. (IPA, K). Pernambuco: Aliança, P. Ferreira 57-71, 4.II.1971, fr. (IPA, SPF); São Lourenço da Mata, I. Pontual 77-1297, 22.XII.1977, fl. fem. (ESA). Piauí: Cocal, O. Koury Jr. 27, 24.XI.1977, fr. (RB). Rio Grande do Norte: Natal, A. Trindade 29, 10.IV.1990, estéril (ESA, IPA). Sergipe: Canindé do São Francisco, M. Fonseca 14271, 8.I.1982, estéril (UEC).

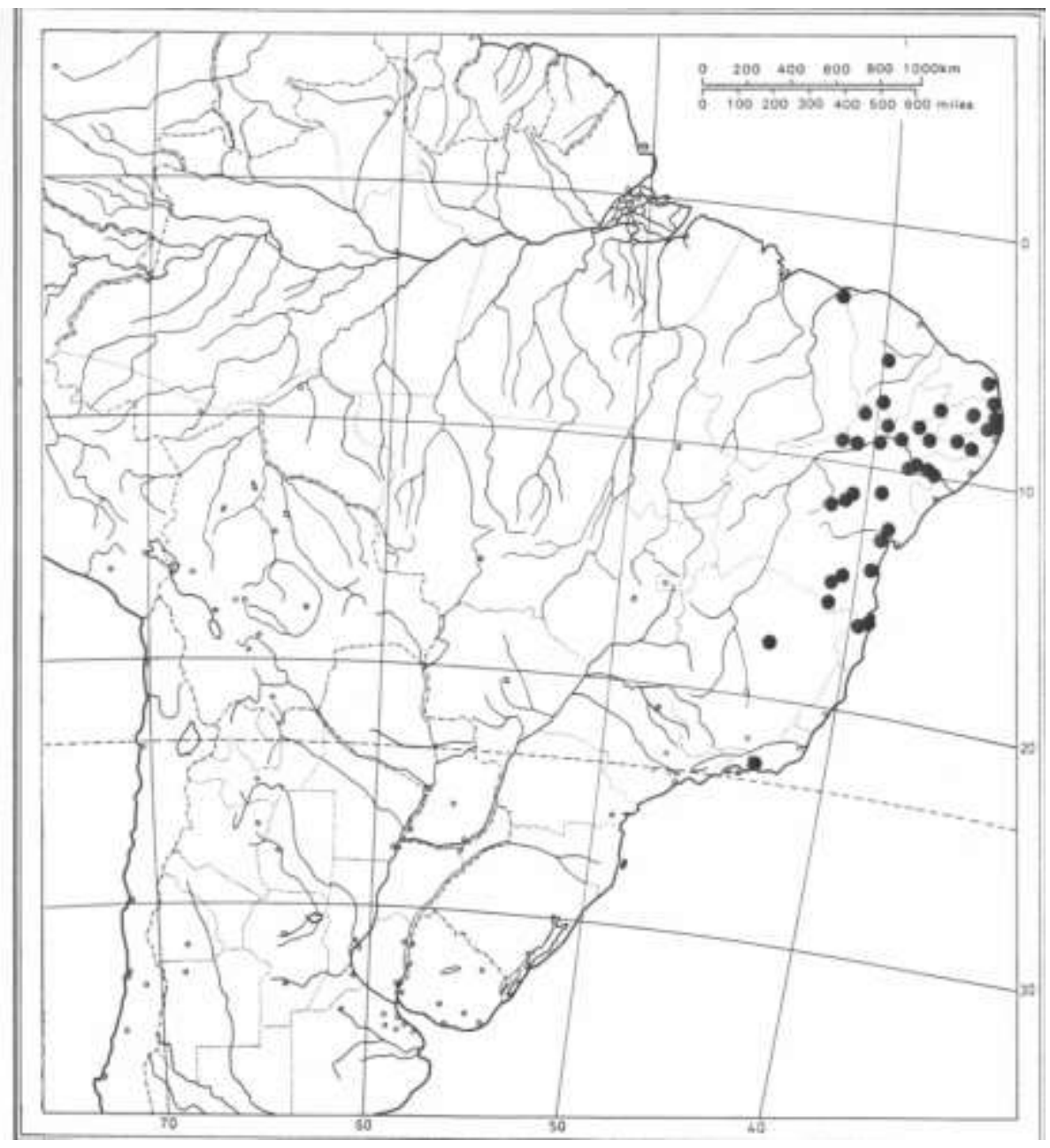

Fig. 16 - Distribuição geográfica de Guapira laxa. 
1.6. Guapira nitida (Mart. ex J.A.Schmidt) Lundell, Wrightia 4(2): 82. 1968. E Pisonia nitida Mart. ex J. A. Schmidt in Mart., FI. Bras. 14(2): 356. 1872. E Pisonia olfersiana var. nitida (Mart. ex J.A. Schmidt) Heimerl, Jber. StOberrealsch. 23: 35. 1897. I Torrubia nitida (Mart. ex J.A.Schmidt) Standl., Contr. U.S. Natn. Herb. 18(3): 101. 1916. Tipo: Brasil, Rio de Janeiro "In sylvis ad Aldea da Escada et praedium Mineiros, prov. Rio de Janeiro", 22.XII.1817, fl. pist., Martius 522a (lectótipo M!, aqui selecionado).

Pisonia acuminata Mart.ex J.A. Schmidt in Mart., FI. Bras. 14(2): 357. 1872. Tipo: Brasil, São Paulo, "in sylvis profundis ad Lorena prov. S. Paulo", Martius 522 b (lectótipo M!, aqui designado). Syn. nov.

Pisonia nitida var. parvifolia J.A.Schmidt in Mart., FI. Bras. 14(2): 357. 1872. Tipo: Brasil, Rio de Janeiro, "in Serra Estrella prov. Rio de Janeiro", Glaziou 3082 (lectótipo K!, isolectótipo P!, aqui selecionado). Syn. nov.

Torrubia hoehnei Standl., Field Mus. Nat. Hist. Bot. 17(3): 242. 1937. E Guapira hoehnei (Standl.) Lundell, Wrightia 4(2): 81. 1968. Tipo: Brasil, São Paulo, Iguape, 21.IX.1929, F.C. Hoehne 24825 (holótipo F, n.v.). Syn. nov.

Fig. 17

Nome vulgar: farinha-seca (Hage 1517)

Arvoreta ou árvore, de 1,5-10,0 m alt., caule 2,0-30,0 cm diâm., liso, às vezes ritidoma presente, avermelhado, os mais delgados às vezes apoiantes; ramos velhos lenhosos, cilíndricos, retos, dicotômicos, às vezes fistulosos, córtex cinza, pubérulos, pouco enrugados a estriados quando secos, ápice normalmente 4-verticilado, pardo-escuros quando secos; ramos novas verdes, retos, cilíndricos, geralmente pouco viloso-ferrugíneo avermelhado, às vezes denso, pretos e enrugados quando secos, normalmente pouco folhosos; entrenós 1,3-15,0 cm compr., quase sempre 2 entre cada ramificação; cicatrizes foliares 2,0-3,0 mm larg., cordiformes, as novas pouco salientes e enrugadas quando secas; gemas 0,5-1,4 mm diâm., densamente ferrugíneas a pardas. Folhas com pecíolos 0,8-3,6 cm compr., em geral opostos e desiguais, em cima glabros, planos exceto a base canaliculada, embaixo pubérulos a glabrescentes, quando secos mais escuros que 0 ramo. Laminas 6,6-30,5 x 3,2-11,3 cm, verticiladas nos nós das ramificações, opostas ou subopostas nos nós não ramificados, às vezes alternas na base de ramos alongados, lanceoladas, oblongo-lanceoladas, elípticolanceoladas, ovado-lanceoladas, oblongas ou elípticas, lâminas frequentemente curvas, base arredondada a obtusa, menos frequente aguda, usualmente muito desiguais, ápice agudo a obtuso, curto-acuminado, caudado a cuspidado, acúmen e cauda normalmente retos e obtusos, carnosas, espessas, até 16 nervuras primárias, em cima glabras, embaixo as novas totalmente hírtulas exceto nervura mediana, as adultas glabras ou às vezes pilosas ao lado da nervura mediana; folhas novas e as menores do par ou do verticilo, ovadas, ovado-elípticas a suborbiculares, 8,5-13,0 cm compr., 6,1-8,1 cm larg., base arredondada a cordada, às vezes cor pouco vináceas, pilosidade macia; quando secas as adultas subcoriáceas, as novas membranáceas flexíveis, pardas a geralmente marrons, raramente ocráceas, concolores ou pouco mais claras em cima, brilhantes ou raramente opacas, nervuras não ou pouco salientes em ambas faces, margem não revoluta com nervura coletora glabra e pouco brilhante; tricomas frequentemente aglomerados pelos ápices, pardoamarelados, célula apical ferrugínea avermelhada, rapidamente decídua. Inflorescências 4,3-16,6 x 2,1$11,8 \mathrm{~cm}$, em geral as pistiladas mais condensadas e menores, terminais em ramos curtos gemados surgindo do verticilo apical desenvolvido, às vezes surgindo de ramos pouco mais velhos, normalmente verticiladas, raramente subverticiladas, eretas ou muitas vezes pêndulas, creme a verde-avermelha das ou alaranjadas, pouco perfumadas, ferrugíneas especialmente nas junções, normalmente longopedunculadas; pedúnculo 3,2-16,6 cm compr., vináceo escuros, ramos finais mais claros, cimeiras terminais trimeras ou comumente aglomeradas, raramente ramos das cimeiras pouco desenvolvidos; brácteas $0,8-2,2 \times$ ca. $0,8 \mathrm{~mm}$, na base dos ramos finais, raríssimo no meio dos ramos primários e secundários, oblongas, ferrugíneas; bractéolas $0,5-1,3 \times$ ca. 0,5 $\mathrm{mm}$, lineares a deltoides, ferrugíneas especialmente no ápice; botões estaminados 3,5-6,0 x 1,5-2,5 mm, oblongo-clavados, às vezes constritos no ápice, base ferrugínea, verdes a creme-esverdeados; flores estaminadas 4,5-6,5 x 2,5-4,5 mm, oblongocampanuladas a afuniladas, em geral ferrugíneas na região basal, base verde a rosada, ápice vermelho a alaranjado, estames 5-9, salientes até $4,0 \mathrm{~mm}$, alvos a verde-avermelhados; botões pistilados 1,5-3,0 x 0,6$1,0 \mathrm{~mm}$, cilíndricos, ferrugíneos desde a base até a constrição mediana, região apical glabra; flores pistiladas 1,5-6,0 x 1,2-2,0 mm, tubuloso-afuniladas a cilíndricas, base ferrugínea, verdes de ápice rosado a maravilha, lobos apicais internamente papilosos; estaminódios 5-8, em geral visíveis acima do espessamento interno; estilete às vezes torcido em flores maiores, estigma saliente por até $3,0 \mathrm{~mm}$, brancos a arroxeados. Infrutescências 8,4-23,3 x 5,2$14,5 \mathrm{~cm}$, verticiladas, longo-pedunculadas, pêndulas; pedúnculo 4,5-13,4 cm compr., até 2,5 $\mathrm{mm}$ espessura, pilosidade ferrugínea esparsa, pouco mais concentrada nas junções dos ramos; pedúnculo e ramos vináceo-escuros; antocarpos 7,0-18,0 x 3,0-5,0 $\mathrm{mm}$, oblongo-elipsoides, base pouco truncada, ápice usualmente agudo, atenuado, ligeiramente pubéruloferrugíneos, tricomas adpressos mais concentrados na base, coroa até 1,0 $\mathrm{mm}$ alt., os imaturos verdevináceos com coroa rosa, os maduros vináceos a negros, estigma saliente até $1,0 \mathrm{~mm}$.

Schmidt (1872) descreveu três novos táxons Pisonia nitida, $P$. nitida var. parvifolia e $P$. acuminata na mesma obra, baseado em vários síntipos, mas com destaque para os espécimes estudados por Martius e considerados como novos táxons nas exsicatas do herbário de M. Para Pisonia nitida foram cinco síntipos 


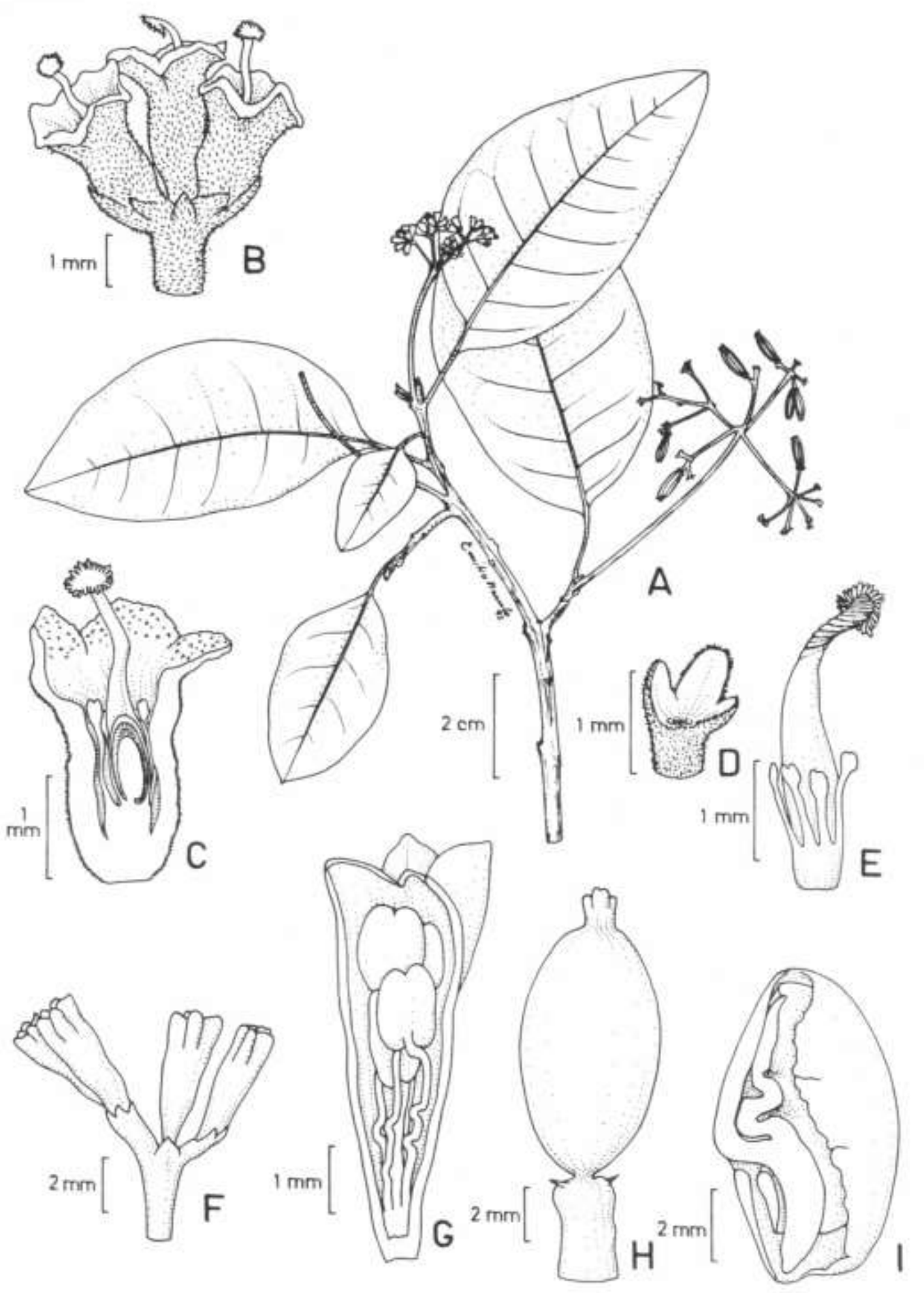

Fig. 17 - Guapira nitida: A. Ramo de planta feminina com flores e frutos. B. Cimeira terminal pistilada. C. Flor pistilada em corte longitudinal. D. Bráctea e bractéolas. E. Ovário e estaminódios com estiletes torcidos. F. Cimeira terminal estaminada com um dos ramos em desenvolvimento. G. Botão estaminado em corte longitudinal mostrando filetes sinuosos. H. Antocarpo com coroa ereta, sobre ramo terminal espessado. I. Embrião em corte longitudinal. (A - A. Loefgren CGGSP 1208; B-E - M. Sobral et al. 7060; F-G - M.A. Assis et al. 317; H-I - J. Mattos et al. 15702). 
coletados nos estados do Rio de Janeiro e Minas Gerais, tendo sido escolhido como lectótipo 0 espécime coletado por Martius 522 a depositado no Herbário de Munique. Um dos síntipos examinados, Regnell III-1021, o único coletado em Minas Gerais, foi identificado nesse trabalho como pertencente a espécie G. opposita (Vell.) Reitz. P. nitida var. parvifolia foi baseada em dois síntipos, sendo o espécime de Sellow, sem localidade indicada, não encontrado nos herbários visitados. Assim, o espécime de Glaziou 3082 também coletado no Rio de Janeiro e depositado em $P$, foi escolhido como lectótipo. Schmidt (1872) refere o material de Glaziou 3082 como "especimina dubia", no que discordamos pois o mesmo se encaixa na descrição da variedade proposta. $P$. acuminata foi descrita a partir de dois síntipos o espécime Martius 522b (M) escolhido como lectótipo da espécie, e o material Glaziou 2665 do Rio de Janeiro. Nos protólogos de $P$. nitida e de $P$. acuminata há apenas a referencia de Martius s.n., porém, no Herbário de Munique esses espécimes aparecem numerados e com as localidades e datas de coleta. O exame dos espécimes mostrou que são praticamente idênticos e também muito semelhantes com o material-tipo de $P$. nitida var parvifolia. Deve ser destacado que todos os síntipos com localidades referidas foram coletados em áreas mais ou menos próximas e os dois lectótipos de Martius foram coletados na mesma data. Portanto, nesse trabalho, $P$. nitida var. parvifolia e $P$. acuminata foram sinonimizadas em $P$. nitida.

Apesar de não ter sido possível o exame do holótipo de Torrubia hoehnei foram examinados os dois parátipos: Loefgren CGGSP 4208 e Hoehne 23855. Os dois são exemplares com folhas novas ainda pilosas e não oblongas, e se mostraram idênticos aos demais materiais com folhas jovens examinados de G. nitida.

Guapira nitida caracteriza-se pelos pecíolos opostos, de comprimentos desiguais, pelas folhas normalmente grandes, glabras e carnosas, com lâminas frequentemente curvas, as novas quase sempre pilosas na face inferior, as folhas dos pares ou dos verticilos geralmente possuem formas e tamanhos bem diferentes, mas as bases são sempre obtusas ou arredondadas e inequiláteras. A espécie está incluída no grupo com inflorescências predominantemente verticiladas, mas pode também apresentar inflorescências subverticiladas, isto é, com ramos primários mais ou menos aglomerados ou pouco distanciados, e pode apresentar também, mais raramente, um ramo alterno abaixo do verticilo de ramos primários.

Guapira nitida por apresentar semelhanca na pilosidade das folhas novas e pelo padrão verticilado de inflorescência pode ser confundida com G. hirsuta. Diferenciam-se porque em $G$. nitida as folhas adultas são glabras e os ramos terminais apresentam poucas folhas, geralmente grandes, lanceoladas, ovais a ovallanceoladas, geralmente curvas, de base obtusa a arredondada e quase sempre assimétrica. Diferentemente, G. hirsuta apresenta as folhas com indumento persistente, ramos terminais frequentemente bem folhosos, folhas em geral pequenas e lanceoladas, de base geralmente aguda e simetrica. Guapira nitida é similar a G. opposita, pelas inflorescências verticiladas, por alguns indivíduos apresentarem folhas grandes, e pela forma das folhas novas. Porém, enquanto $G$. nitida possui folhas novas pilosas, ovais, de base obtusa a arredondada e folhas adultas frequentemente oblongas a oblongolanceoladas, usualmente com base notavelmente inequilátera e consistência subcoriácea, G. opposita apresenta folhas novas glabras ou com pilosidade muito esparsa, lanceoladas e de base aguda e folhas adultas em geral elípticas a lanceoladas não curvas, de base aguda não desigual e consistência cartácea. Essa caracterização difere da proposta feita por Reitz (1970), que sinonimizou os binômios Pisonia nitida e $P$. acuminata sob Guapira opposita, porém sem mencionar consulta aos tipos nomenclaturais.

Em algumas inflorescências pistiladas de $G$. nitida foram encontradas flores com dois estigmas salientes pertencentes a dois carpelos diferentes. Um deles tem as características normais do gineceu da espécie, e o outro tem o ovário e o estilete mais delgados e 0 estigma menos penicelado, provavelmente não funcionais pois nunca foram vistos dois frutos no mesmo antocarpo. Também nesta espécie foi notada, em flores pistiladas maiores, a ocorrência de estiletes torcidos talvez indicando fecundação.

Distribuição geográfica e habitats (Fig. 18): Guapira nitida ocorre de preferência no interior da Mata Atlântica litorânea, em locais bastante úmidos e sombreados, mas foi observada também em matas de restingas e em locais mais abertos ao longo de trilhas na região de Ubatuba. Trata-se de espécie pouco comum.

Material selecionado: Brasil. Bahia: Ilhéus, J.L. Hage 1517, 10.XI.1981, fl. fem. (CEPEC, SPF). Espírito Santo: Cachoeiro do Itapemirim, A.C.Brade 19368, 28.VIII.1948, fl. fem. (RB). Rio de Janeiro: Parati, A.M.S.F. Vaz 584, 20.X.1988, fr. (HRB); Rio de Janeiro, Serra d'Estrela, $A$. Glaziou 3082, 1.XI.1868, fl. masc. (K, P, síntipo de P. nitida var. parvifolia). São Paulo: Cubatão, F.C. Hoehne 23855, 23.VIII.1899, fl. est., parátipo de T. hoehnei (SP); Praia Grande, A. Loefgren CGGSP4208,10.XI.1888, fl. fem., fr, parátipo de T. hoehnei (SPF). 


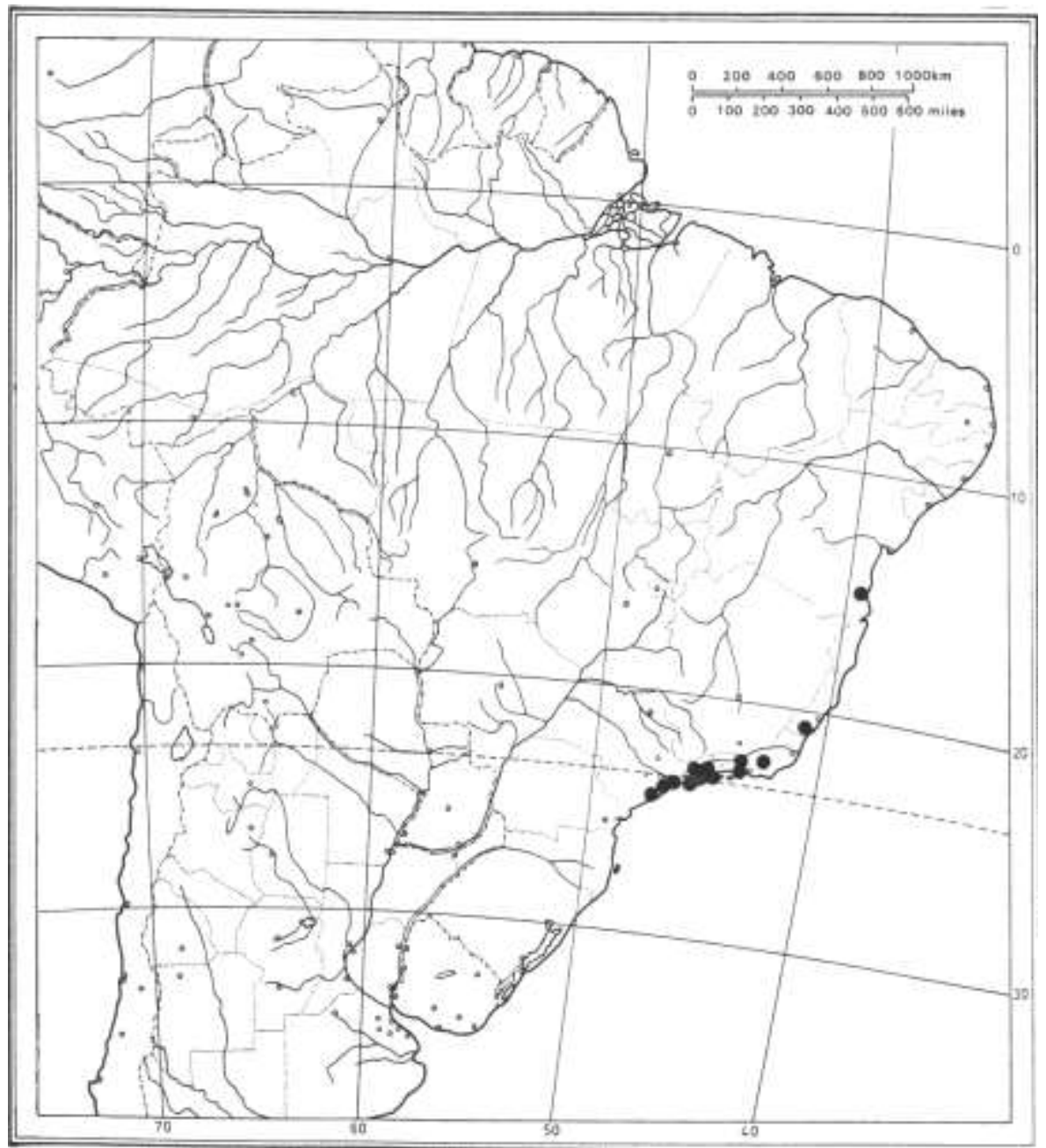

Fig. 18 - Distribuição geográfica de Guapira nitida.

1.7. Guapira noxia (Netto) Lundell, Wrightia 4(2): 83. 1968. E Pisonia noxia Netto, Ann. Sci. nat. ser. 5, Bot. 5: 80. 1866. इ Torrubia noxia (Netto) Standl., Contr. U.S. Natn. Herb. 18(3): 101. 1916. Tipo: Brasil, "in campis occidentalibus provinciae Minas Geraes, Morada Nova", L. Netto 226 (lectótipo R!, aqui designado).

Pisonia obtusata Sw. var. rufescens J.A.Schmidt in Mart., FI. Bras. 14(2): 362. 1872. Tipo: Brasil, Burchell 5427 (lectótipo K!. aqui designado). Syn. nov.

Fig. 19

Nomes vulgares: pao-judeu, pao-lepra, joão-mole (Netto 1866a, b); joão-mole-do-campo (Claussen 407 e 408); capa-rosa (A.F. Silva s.n. HRCB 4044).

Arbusto, arvoretas ou árvores, 2,0-10,0 m alt., caducifólios, caule 6.0-18.0 cm diâm., em geral tortuosos e nodosos, súber espesso e fendido; ramos finais lenhosos, cilíndricos, retos ou pouco tortuosos; córtex rimoso, cinza; ramos novos verdes, até $5 \mathrm{~mm}$ espessura, cilíndricos, retos, enrugados quando secos, ferrugíneo-tomentosos a glabrescentes; entrenós curtos, aglomerados, ou até $5.3 \mathrm{~cm}$ compr.; cicatrizes foliares $3.0-5,0 \mathrm{~mm}$ larg., geralmente bem salientes; gemas 3.0-7,0 mm diâm., ferrugíneotomentosas, aglomeradas nos ápices dos ramos e na base das inflorescências, às vezes subopostas. Folhas com pecíolos 0,8-3.5 cm compr., 0.5-3.5 mm espessura, glabros ou ferrugíneos no dorso. Laminas 5.2-26,4 x 2,7-11,3 cm larg., as adultas orbiculares, oblongo-orbiculares, elípticas, obovadas, ou elípticoobovadas, frequentemente assimétrica e côncava, margem inteira, muitas vezes irregular, base arredondada a obtusa, atenuada, raramente até 0 meio do pecíolo, comumente inequilátera, ápice arredondado a obtuso, raramente curto-acuminado, muitas vezes emarginado, face superior verde-glauca, glabra, face inferior tomentosa ferrugíneoavermelhada, aveludada, glabrescente ou não, normalmente carnosa; quando seca com face superior castanho-acinzentada, glabras e face inferior, castanha, pilosas, indumento ferrugíneo-avermelhado muitas vezes as mais delgadas pretas com manchas verde-amareladas, cartáceas a subcoriáceas, firmes, 

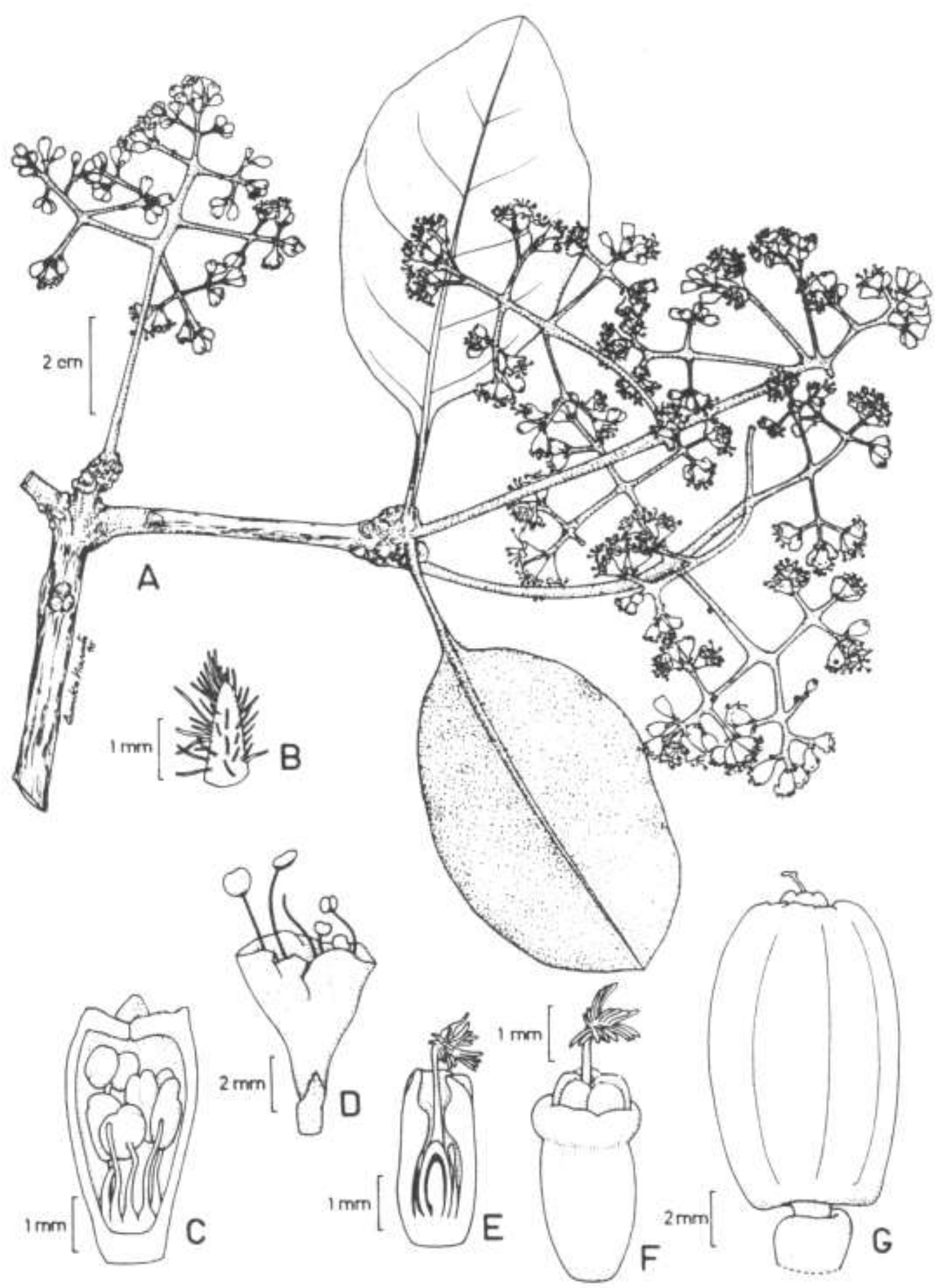

Fig. 19 - Guapira noxia: A. Ramo de planta estaminada. B. Brácteas das címulas. C. Flor estaminada com cálice em corte longitudinal. D. Flor estaminada inteira. E. Flor pistilada em corte longitudinal. F. Flor pistilada em início de frutificação. G. Antocarpo costado. (A - H.S. Irwin et at 7959; B-D - A.A.A. Barbosa et al. 112; E - I. Schiavini et al.129; F - R.C. Vieira et al. s.n. HUFU 194; G - S.N. Pagano 591). 
Folhas novas membranáceas firmes, elípticas a obovadas, face inferior totalmente ferrugíneas ou apenas nervura mediana ferrugínea, ou subglabras nas duas faces, base obtusa, as menores de base aguda, margem em geral inteira, quando secas membranáceas, pretas a marrons; tricomas ramificados, célula apical oblonga, avermelhada. Inflorescências estaminadas 4,0-13,4 x 3.1-9,5 cm, as pistiladas 3,3-5,8 x 2,6-4,6 cm, ferrugíneoesverdeadas, aromáticas, usualmente em ramos curtos com gemas, frequentemente várias no ápice de ramos espessos sem folhas; pedúnculo 1,1-8,3 cm compr., ramos opostos ou alternos, normalmente patentes nas inflorescências estaminadas e ligeiramente oblíquos nas pistiladas, usualmente retos e pouco espessos, às vezes gemas presentes nas bifurcações e junções, ramos finais $0,7-1,2 \mathrm{~mm}$ espessura, quase sempre ferrugíneos, cimeiras terminais aglomeradas ou laxas, com desenvolvimento gradual; brácteas dos ramos finais e das címulas até $2,5 \mathrm{~mm} \times$ ca. $0,5 \mathrm{~mm}$, oblongas, ferrugíneas; bractéolas 0,8-2,0 mm compr., deltoides a lineares, ferrugíneas especialmente no ápice, tricomas relativamente longos; botões estaminados 2,5-6.0 x $1,5-3,4 \mathrm{~cm}$, usualmente clavados, glabros ou poucos tricomas esparsos, em vários estágios no mesmo ramo, quando secos muitas vezes negro-esverdeados; flores estaminadas 4,5-7,0 $\mathrm{mm} \times 3,5-5,8 \mathrm{~mm}$, campanuladas, ápice papiloso; estames $6-8$, salientes até $4,0 \mathrm{~mm}$; anteras ca. $1,0 \mathrm{~mm}$ compr., cremeamareladas, marrom-claras após a deiscência; botões pistilados 1,5-3,5 x 0,8-1,5 mm, cilíndricos, pouco constritos no meio, pouco pilosos, flores pistiladas 2,0$3,9 \times 1,0-2,2 \mathrm{~mm}$, tubulosas, lobos apicais papilosos internamente, eretos ou incurvados para dentro, glabras ou pouco tricomas mais concentrados no ápice; estigma saliente até $2,0 \mathrm{~mm}$. Infrutescências 6,0-16,8 x 4,0-11,8 cm, ferrugíneas a geralmente glabrescentes; pedúnculo 3,2-8,4 cm compr., até 2.7 $\mathrm{mm}$ larg., ramos primários opostos ou em geral alternos, patentes, até $1,9 \mathrm{~mm}$ espessura; antocarpos 6,0-14,0 x 3,0-6,2 mm, os jovens oblongos, verdes, em geral constritos pouco abaixo da coroa quando secos, os adultos elipsoides a geralmente oblongos, glabros, base e ápice frequentemente truncados, vermelhos a negros, costados quando secos; coroa apical 0.5,-1,0 $\mathrm{mm}$ alt., fechada, ferrugínea, às vezes não visível, imersa no antocarpo truncado; estigma saliente até 1,0 $\mathrm{mm}$, às vezes apenas visível na margem da coroa apical.

Guapira noxia caracteriza-se pela inflorescência com ramos opostos bem patentes, geralmente inflexíveis e retos, e pelas folhas novas elípticas de ápice obtuso a arredondado, pilosas em geral na face inferior. Muitas vezes as folhas adultas da espécie apresentam margem irregular, que não parece ser resultado de predação. Geralmente, a flor pistilada em início de frutificacdo apresenta um forte espessamento pouco acima do ovário, que não ocorre no antocarpo adulto.
A espécie mais similar com Guapira noxia é $G$. laxa, mas essa apresenta a inflorescência com ramos oblíquos, normalmente flexiveis e delgados, e as folhas novas são ovadas a ovado-elípticas, acuminadas, em geral pilosas nas duas faces.

Dos vários síntipos referidos por Netto (1866a) para Pisonia noxia, o espécime Netto 226 foi citado como ocorrendo no Herbário $P$. Como esse espécime não foi encontrado no herbário referido, mas foi examinado material bem completo depositado no herbário $R$, esse espécime foi escolhido como lectotipo.

Schmidt (1872) coloca Pisonia noxia na sinonímia de $P$. tomentosa Casar., mas as duas espécies são bem distintas e consideradas válidas, pois enquanto Guapira noxia apresenta inflorescência laxa com ramos em geral opostos, e folhas com margens nunca revolutas, com pilosidade ferrugíneoavermelhada, G. tomentosa apresenta inflorescência verticilada e aglomerada, subcapituliforme, e folhas com margens revolutas e pilosidade é castanho-escura. $\mathrm{O}$ problema em relação a delimitação das duas espécies por Schmidt (1872) foi os materiais examinados por esse autor pois enquanto Burchell 6024 enquadra-se bem em G. noxia, Blanchet 3772 deve ser identificado como G. laxa. Tal situação apresentada na Flora Brasiliensis provavelmente é a explicação para as inumeras identificações em herbários, de espécimes de G. noxia como G. tomentosa.

Schmidt (1872) descreveu Pisonia obtusata var. rufescens baseado em quatro síntipos, dos quais Riedel s.n. e Lund 20 não foram localizados e Glaziou 2897 foi identificado com Guapira laxa (Netto) Furlan. O espécime Burchell 5427 está bem preservado em K, e confere com a curta descrição da variedade, sendo feita a lectotipificação do táxon baseado no mesmo. $O$ exame do espécime mostrou que em nada difere de Guapira noxia e está sendo aqui sinonimizado nessa espécie.

Distribuição geográfica e habitats (Fig. 20): Guapira noxia é uma espécie típica dos cerrados brasileiros e tem seu limite sul de distribuição em Angatuba no estado de São Paulo, na altura do Trópico de Capricórnio.

Material selecionado: Brasil. Distrito Federal: Brasília, J.H. Kirkbride Jr. 4367, 24.VIII.1981, fl. masc. (UB); J.A. Ratter 3761, 12.X.1976, fl. masc. e fem. (K, UB, UEC). Goiás: Cristalina, G. Hatschbach 44052, 7.X.1981, fl. masc. (MBM); Formosa, L.C. Oliveira f 15, 18.IX.1978, fl. fem. (HRB, RB, UB); sem local, A. Saint-Hilaire 169 Cat $C^{\prime}$ 911, 1816/1821, fl. masc. (P, síntipo de $P$. noxia). Minas Gerais: rio Paraopeba, E.P. Heringer 5765, 10.X.1957, fr. (PMG, UB); Santana do Riacho, A. Furlan et al. CFSC 6742, 8.XI.1980, fl. fem. (SPF). Mato Grosso: Chapada dos Guimarães, A.T. Oliveira f. 145, 4.IX.1983, fl. masc. (ESAL, UEC); Xavantina, G. Argent et al. 6555, 27.IX.1967, fr. (K, P, UB). Mato Grosso do Sul: Selviria, A.B. Martins et al. 56, 6.XI.1985, fr. (CEN, HRCB, ISA, SP, UB, UEC). São Paulo: UEC); Analândia, S.N. Pagano 164, 18.IX.1984, fl. masc. (HRCB); Botucatu, A. Amaral Jr. et al. 20, 10.X.1985, fl. masc. (SP, UEC). 


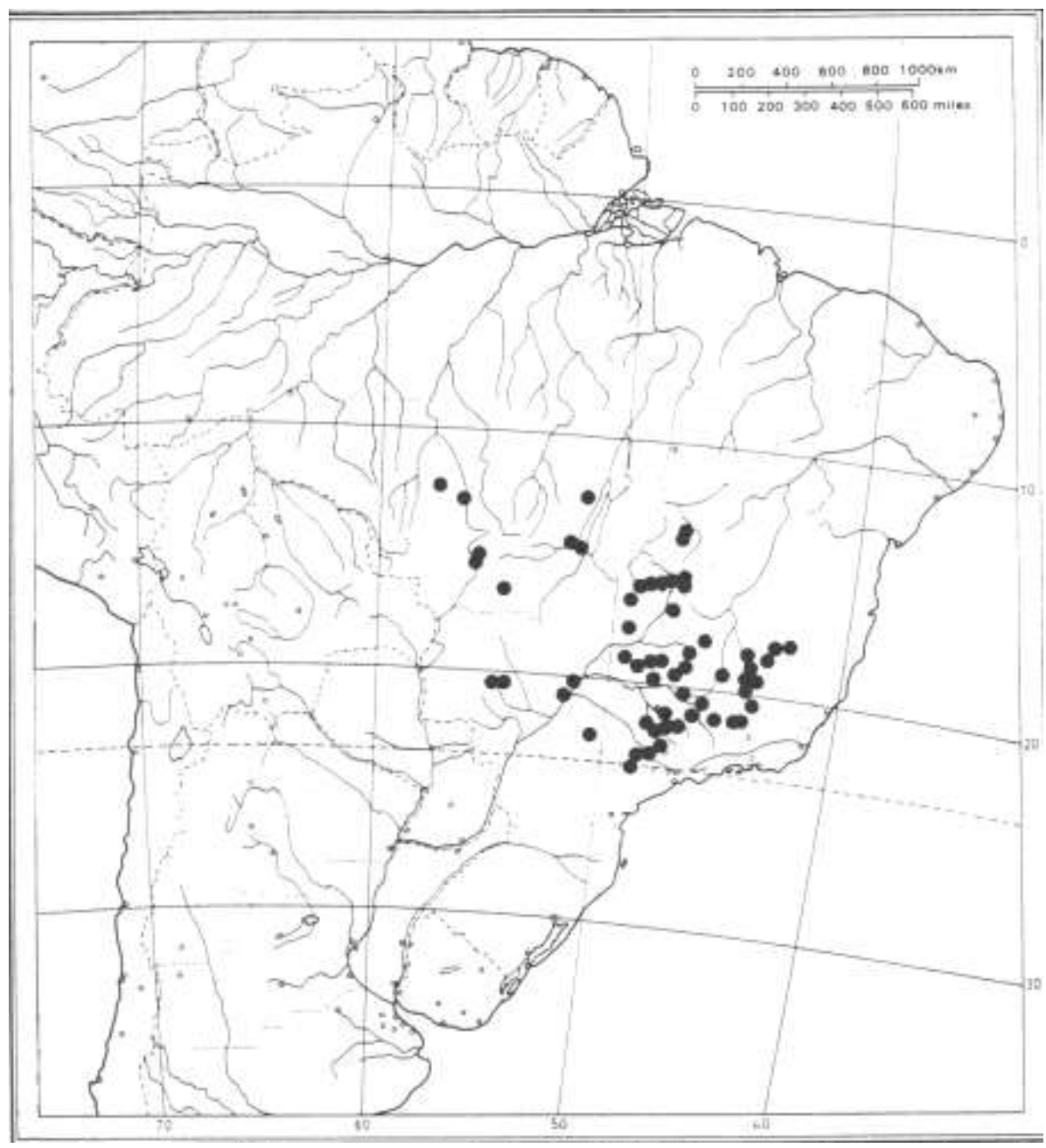

Fig. 20 - Distribuição geográfica de Guapira noxia.

1.8. Guapira obtusata (Jacq.) Little, Phytologia 17(5): 368. 1968. I Pisonia obtusata Jacq., PI. Hort. Schoenbr. 3: 35, pl. 314. 1798. E Torrubia obtusata (Jacq.) Britton, Bull. Torrey bot. Club 31: 612. 1904. Tipo: "in insula Providentiae, in caldario, majo \& junio" (n.v.).

Pisonia nigricans Sw. var. oblonga Choisy in DC., Prodr. 13(2): 442. 1842. Tipo: "Brasiliae in provinciis Jacobina et Moritiba", 1837, fl. est., Blanchet 3596 (lectótipo, P!, isolectótipos BM!, BR!, aqui designado). Syn. nov.

Pisonia combretiflora Mart. ex J.A.Schmidt in Mart., FI. Bras. 14(2): 360. 1872. = Torrubia combretiflora (Mart. ex J.A. Schmidt) Standl., Contr. U.S. Natn. Herb. 18(3): 100. 1916.

Tipo: Brasil, "in deserto Minarum Novarum, ad fluv. Arassuahy", Martius s.n. (holótipo, M!). Syn. nov.

Torrubia cokeri Britton, Bull. Torrey bot. Club 31: 613. 1904. Tipo: Bahamas, "Tarpum Bay, Eleuthera", Coker 401 (holótipo, n.v.).

Fig. 21
Nomes vulgares: farinha-seca (Rylands 45/1980); farinha-seca-miúda (Ferreira 407).

Arbustos ou árvores, 0,5-25,0 m alt., caule 5.0$54 \mathrm{~cm}$ diâm., cilíndrico ou achatado, às vezes não ramificado até $7 \mathrm{~m}$ alt., casca áspera, copa até $10 \mathrm{~m}$ diâm.; ramos velhos lenhosos, cilíndricos, tortuosos, raramente retos, córtex esbranquiçado, lenticelado, lenticelas longitudinais, os superiores em geral murchos, enrugados a estriados quando secos; ramos novos cilíndricos, glabros, às vezes os muito novos com pilosidade esparsa pulverulenta ferrugínea, quando secos negros a pardos, compressos; entrenós 0,6-4,5 cm compr., às vezes aglomerados na base dos ramos novos, cicatrizes foliares ca. $0,5 \mathrm{~mm}$ compr., $1,5 \mathrm{~mm}$ larg., geralmente as inferiores mais compridas que largas, salientes; gemas até 1,0 mm diâm., pubérulas, ferrugíneo-avermelhadas. Folhas com pecíolo 0,3-2,5 cm compr. glabro, subalado, frequentemente com linhas de deiscência mais escuras na base. Folhas adultas 5,6-12,0 x 3,5-6,6 cm, 

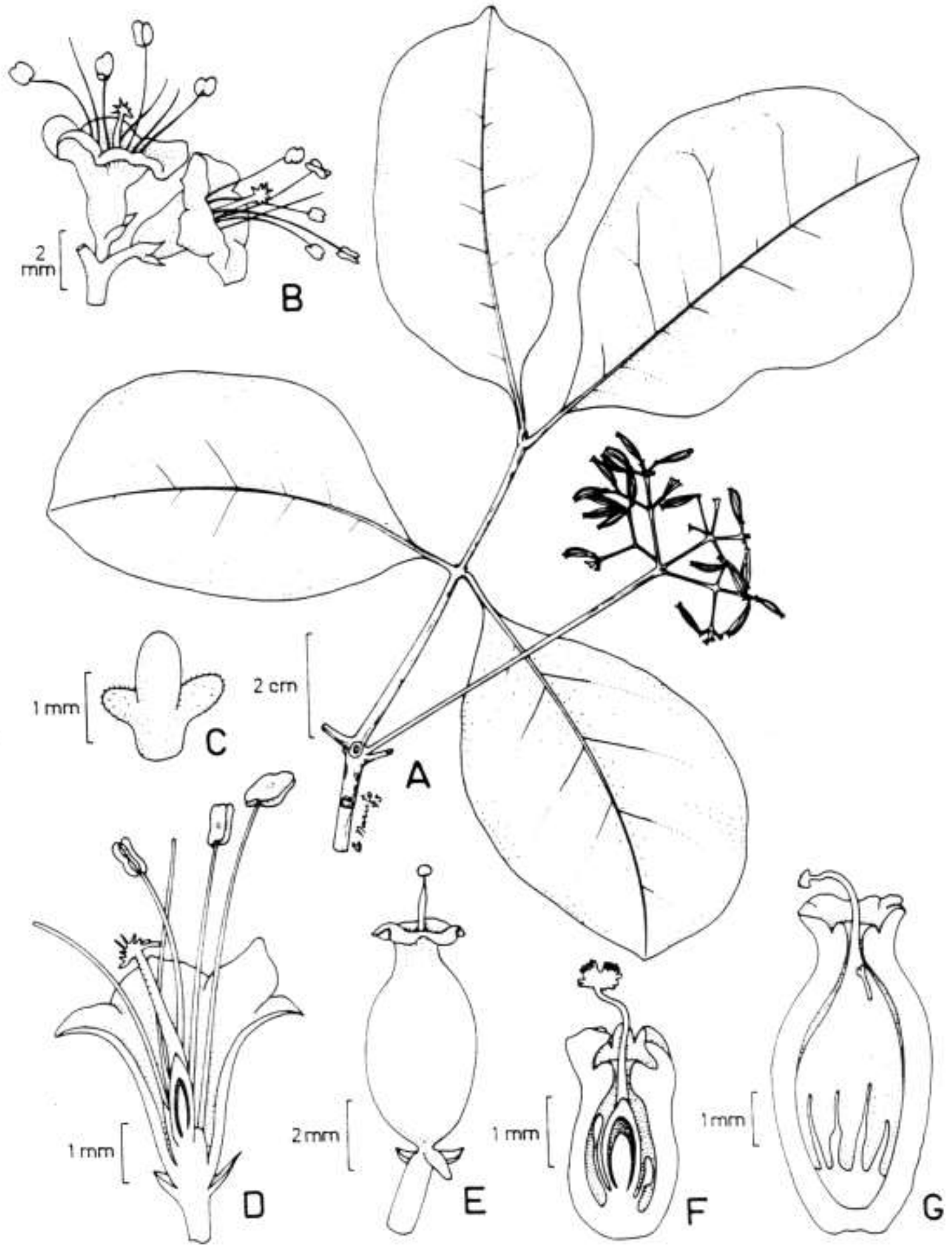

Fig. 21 - Guapira obtusata: A. Ramo frutífero. B. Címula estaminada com râmulos pouco desenvolvidos, mostrando pistilódios salientes. C. Brácteas e bractéolas. D. Flor estaminada em corte longitudinal. E. Antocarpo. F. Flor pistilada em corte longitudinal. G. Antocarpo em corte longitudinal. (A - D. Araujo 6990. B, D - G.L. Farias 17. C, F - P. Vinha 927. E, G - A.M. Carvalho el al. 206). 
obovado-orbiculares a obovadas, base aguda, atenuada no pecíolo, ápice arredondado, às vezes obtuso curto-acuminado, margem pouco ou não recurvada, pares em geral iguais, raramente pouco desiguais, as novos quase sempre bem desiguais, carnosas, glabras, verdes, quando secas brilhantes, um pouco menos embaixo, cartáceas, marrons a verde-pardas, nervuras pouco salientes nas duas faces, um pouco mais saliente embaixo, nervura mediana em geral evanescente, às vezes bifurcandose no final e não atingindo o ápice; folhas novas 3,5$11,2 \times 2,5-7,8 \mathrm{~cm}$, opostas ou subopostas, formas variadas, obovadas, suborbiculares, oblongoobovadas, ou subespatuladas, base aguda, longoatenuada, glabras ou pilosidade esparsa ferrugíneopulverulenta mais concentrada nas margens e ao lado da nervura mediana, quando secas negras a marrons, ligeiramente mais escuras em cima, nervuras não ou pouco salientes, usualmente mais escuras que a lâmina. Inflorescências 2,5-15,0 x 1,8-10,5 cm, terminais, hemisféricas, glabras ou pilosidade muito esparsa, pouco concentrada nas junções; pedúnculo 2,2-8,2 cm compr., às vezes $1,1 \mathrm{~cm}$ compr. em inflorescências depauperadas, reto, ereto, inflexível, às vezes com gemas no ápice; ramos primários verticilados ou subverticilados, de comprimentos diferentes, usualmente oblíquos ao pedúnculo, os secundários com ramificação variada; címulas terminais trímeras, às vezes com ramos laterais desenvolvidos; brácteas até $3,5 \times$ ca. $0,5 \mathrm{~mm}$, lanceoladas a oblongas, na base dos ramos secundários e das címulas, pilosas no dorso, deciduas; bractéolas 0,5-1,0 mm compr., deltoides, pouco pilosas, especialmente no ápice, patentes na frutificação; botões estaminados 2,5-3,0 x 1,3-1,7 mm, clavados, estreitados na base, glabros, ápice papiloso; flores estaminadas 3,0-5,0 x 2,5-4,0 mm, campanuladas, amarelo-esverdeadas, bordas avermelhadas, perfumadas; estames 6-10, usualmente 7 , salientes até $4,0 \mathrm{~mm}$, filetes às vezes unidos até $3,5 \mathrm{~mm}$, anteras marrons, pistilódio muitas vezes saliente até $1,0 \mathrm{~mm}$ compr.; botões pistilados 1,5-2,0 x 0,8-1,1 mm, cilíndricos, constritos próximo do ápice, glabros; flores pistiladas 2,0-3,0 x 1,5-2,0 mm, tubulosas; lobos apicais patentes a reflexos, às vezes não enegrecidos quando secos; estigma saliente até $1,5 \mathrm{~mm}$. Infrutescências 5,0-13,0 x 4,3-8,5 cm, terminais, glabras; pedúnculo $3,5-7,8 \times$ ca. $1,8 \mathrm{~mm}$, ereto, reto, inflexível, vermelho-vináceo; bractéolas patentes; antocarpos 4,0-6,5 x 2,7-3,5 mm, elipsoides, em geral pouco estreitados no ápice, brilhantes, vermelho-arroxeados a negros; coroa apical até 0,5 $\mathrm{mm}$ alt., pátula; estigma saliente até 1,0 $\mathrm{mm}$.

A descrição no protólogo é insuficiente para uma identificação segura de Guapira obtusata, e não foi possível examinar sua ilustração. Segundo D'Arcy (1970) as espécies de Jacquin são dificeis de serem tipificadas, não havendo atualmente um "herbário de Jacquin", e seus materiais podem ser encontrados dispersos em vários herbarios europeus. Britton (1904) e Heimerl (1921) estudaram extensivamente as plantas da localidade típica mas não mencionam o material-tipo de G. obtusata Jacq. Entre os espécimes citados por Choisy (1849) como P. obtusata Sw. estão Mart. Herb. 972 e Blanchet 1898. Schmidt (1872) refere para a mesma espécie os materiais Gaudichaud 408 e Luschnath in Mart. Herb. 972, além de outros materiais que são aqui identificados como pertencentes a outras espécies: Glaziou 2666 é Guapira opposita e Burchell 7533 é G. noxia.

Entre os materiais identificados como $G$. obtusata de fora do Brasil estão Combs 731, de Cuba, determinado por Westra, e Ekman in Regnell 1116313 também de Cuba, determinado por Heimerl. Ambos são extremamente semelhantes aos espécimes do Brasil ora identificados como $G$. obtusata. Conferindo mais confiabilidade na circunscrição desta espécie, a comparação do material brasileiro com plantas provenientes da localidade-tipo, como Michaux 90 e Eggers 4354 das Ilhas Providence nas Bahamas, demonstrou plena semelhança. $O$ material do Brasil é compatível também com a descrição original de $P$. obtusata, exceto pelo pecíolo, que aqui são mais longos, especialmente os das folhas novas.

Britton (1904), avaliando as espécies do Caribe, tentou resolver os problemas da aplicação dos homônimos $P$. obtusata Jacq. e $P$. obtusata Sw. Este último vinha sendo usado indevidamente para plantas pertencentes a $P$. obtusata Jacq., um nome anterior ao de Swartz. P. obtusata Jacq. teria folhas ovais ou elípticas, espessas, ápice arredondado, base subcordada a pouco estreitada, pecíolos espessos, e ocorreria nas ilhas Providence nas Bahamas (próximo da Flórida). P. obtusata Sw. possuiria folhas de ápice agudo, pecíolo delicado e delgado, e seria restrita à ilha de São Bartolomeu (próximo de Porto Rico, distante aproximadamente $1300 \mathrm{~km}$ das Bahamas). Assim Britton (1904) sinonimizou P. obtusata Sw. sob Torrubia inermis (Jacq.) Britton e descreveu uma espécie nova das Bahamas, T. cokeri, com pecíolos de 10-15 mm compr. e folhas cuneadas ou estreitadas na base. O estudo do material Linden 1988, parátipo de $T$. cokeri, não permite separá-lo dos materiais ora identificados como $G$. obtusata, confirmando a sinonimizacão de $T$. cokeri em $T$. obtusata (Jacq.) Britton efetuada por Standley (1918), posição aceita por Heimerl (1921) e nesse trabalho.

Segundo Fawcet \& Rendle (1914), T. obtusata (Jacq.) Britton teria folhas coriáceas, elípticas a obovado-elípticas, de ápice largo-arredondado e base cuneada ou arredondada. A descrição destes autores é bem condizente com as características dos espécimes brasileiros.

O holótipo examinado de Pisonia combretiflora Mart. ex J.A. Schmidt, apesar de possuir folhas pequenas, mostrou ser apenas uma variação de $G$. obtusata relacionada ao ambiente de cerrado, levando á sinonimização aqui proposta.

As folhas de $G$. obtusata, segundo Diaz \& Esquivel (1983), são muito semelhantes às de Pisonia rotundata Griseb., contudo esta última é incluída em Pisonia devido aos seus antocarpos secos e 
glandulosos, apesar de Lundell (1968) tê-la transferido incorretamente para Guapira como $G$. rotundata (Griseb.) Lundell. Nos herbários verifica-se que a maior parte das plantas do Caribe identificadas como $P$. rotundata Griseb. realmente possuem folhas semelhantes as de $G$. obtusata, porém seus antocarpos são secos e glandulosos. Entre os materiais examinados do Brasil não foi encontrada qualquer planta que pudesse ser identificada como Pisonia rotundata.

Guapira obtusata é semelhante com $G$. opposita, da qual se diferencia por essa última espécie ter as folhas de base em geral aguda e ápice arredondado a obtuso e pelas inflorescências com pedúnculo normalmente ereto, reto e inflexível. Também, possui flores estaminadas com pistilódios bem desenvolvidos e salientes e as flores pistiladas com os estigmas também bem salientes.

Distribuição geográfica e habitats (Fig. 22): a distribuição de $G$. obtusata no Brasil abrange os estados do Nordeste e Sudeste. Pela região costeira ocorre desde o Ceará até São Paulo, havendo uma coleta de Gaudichaud mencionando Santa Catarina, que seria seu limite Sul. Ocorre principalmente em dunas, matas costeiras, matas semideciduais, matas de restinga e eventualmente em cerrado e campos rupestres.

Material selecionado: Brasil. Bahia: Itabuna, R.M. Harley et al. 17630, 1.IV.1974, fl. fem. (IPA, K, M); Poço d'Areia, Blanchet 3875, s.d., fl. fem. (BM, BR, P, síntipo de $P$. nigricans var.oblonga Choisy); Porto Seguro, G.L. Farias 177, 26.IV.1988, fl. masc. (CVRD, HRCB, SPF). Ceará: Maranguape, J.H. Kirkbride Jr. S.n., 3.X.1952, bot. masc. (EAC 936, UB). Espírito Santo: Guarapari, O.J. Pereira et al. 173, 21.IX.1982, fl. fem. (HRCB, SPF, VIES). Minas Gerais: Caeté, V.C. Souza \& C.M. Sakuragui 2093, 13.X.1992, fl. masc. (ESA, SPF). Pernambuco: Taquaritinga do Norte, Andrade-Lima 72-7158, 28.XII.72, bot.masc. (IPA, SPF). Rio de Janeiro: Angra dos Reis, D. Araujo 8756, 16.III.1989, fr. (GUA); Rio de Janeiro, E. Pereira et al. 4336, 23.IX.1958, fl. masc. (FIB, RB). Santa Catarina: sem local, Gaudichaud 157 e 187, 1833, fl. masc. (P). Sergipe: Neepolis, Equipe Pedologia s.n., 1968, estéril (IPA 16915). São Paulo: Itanhaém, D. Araujo \& M.C.A. Pereira 6538, 19.I.1985, fl. fem./fr. (GUA).

Bahamas. Ilhas Providence, Eggers 4354, 3.III.1888, fl. fem. (P); Michaux 90, s.d., fl. fem. (P).

Cuba. R. Combs 731, 3.IV.1896, bot. masc. (P); Ekman in Regnell 111-6313, 3.VIII.1915, fr. (K, P); J. Linden 1988, VI.1844, fl. masc. (K, P, parátipo de T.cokeri).

Porto Rico. P. Sintenis 594, 19.II.1885, fl. masc. (P).

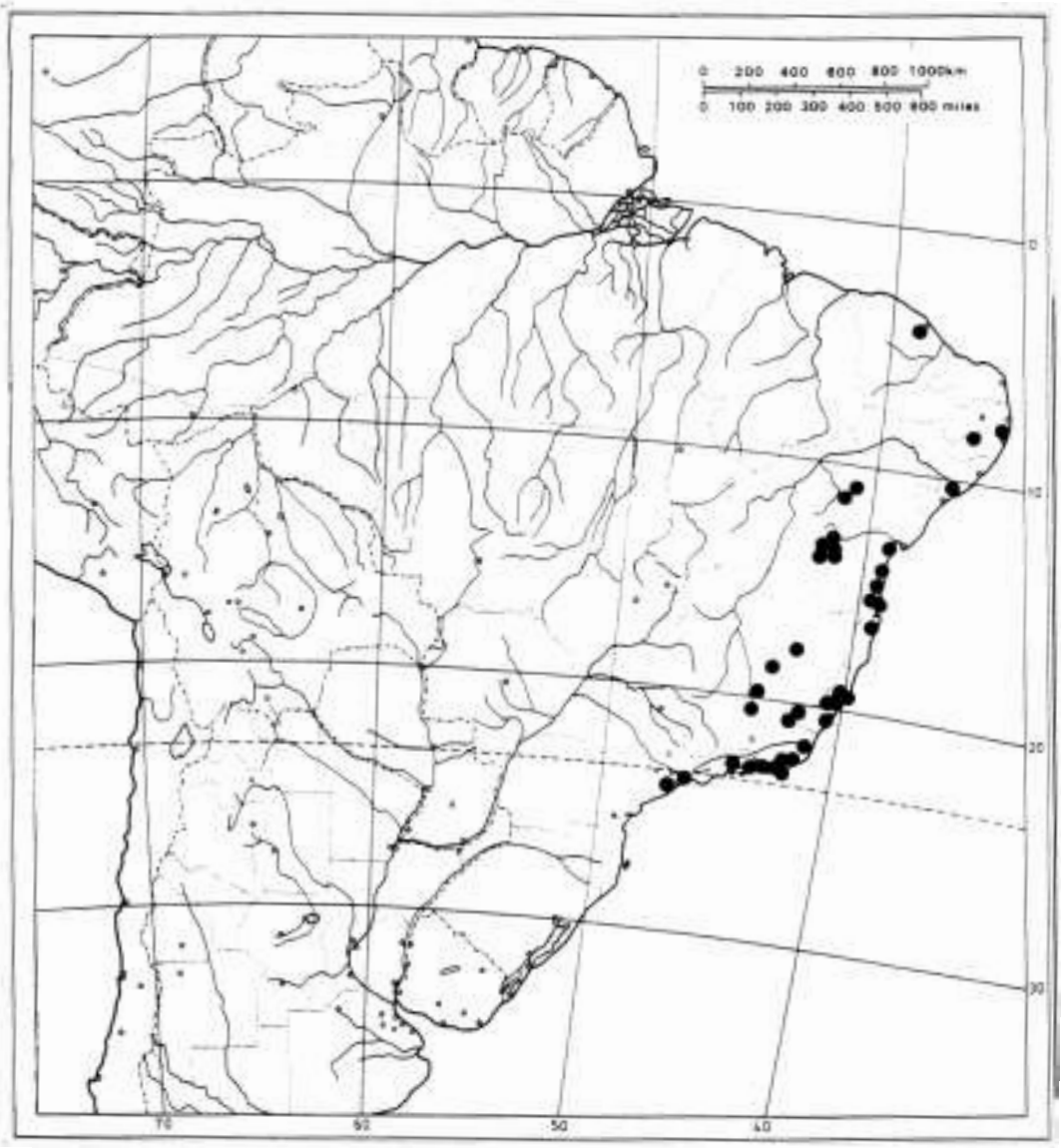

Fig. 22 - Distribuição geográfica de Guapira obtusata no Brasil. 
1.9. Guapira opposita (Vell.) Reitz, Fl. ilustrada catarinense, Nictagináceas: 32. 1970. Torrubia opposita Vell., Fl. flumin.: 139. 1829. Icones 3: tab.150. 1831. Tipo: Icones 3: tábula 150. 1831 (lectótipo, aqui designado).

Bessera calicantha Vell., FI. flumin.: 147. 1829. Icones: tab.2. 1831. Tipo: Icones 4:

tab.2. 1831 (lectótipo, aqui designado).

Columella rustica Vell., Fl. flumin.: 155. 1829. Icones 4: tab.17. 1831. Tipo: Icones 4: tab.17. 1831 (lectótipo, aqui designado). Syn. nov.

Pisonia olfersiana Link, Otto \& Klotzsch, Icon. PI. rar. 1(3): 37. tab.15. 1841. Tipo: Icon. PI. rar. 1(3): tab.15. 1841 (lectótipo, aqui designado).

Pisonia minor Choisy in DC., Prodr. 13(2): 443. 1849. Tipo: Brasil, "Jacobina prov. Bahiae", 1842, fl. est., Blanchet 3592 (lectótipo P!; isolectótipos P! (3 exs.) BR!, BM!, K! (2 exs.), aqui designados). Syn. nov.

Pisonia laxiflora Choisy in DC., Prodr. 13(2): 444. 1849. $\equiv$ Torrubia laxiflora (Choisy) Standl., Contr. U.S. Natn. Herb. 18(3): 100. 1916. 三 Guapira laxiflora (Choisy) Lundell, Wrightia 4(2): 82. 1968. Tipo: Brasil, "ad Ilheos", 1836, fl. est., Martius herb. 973 (lectótipo $\mathrm{M}$ !, isolectótipos $\mathrm{BR}$ !, P!, $\mathrm{K} !, \mathrm{BM}$ !, aqui designados). Syn. nov.

Pisonia comosa Choisy in DC., Prodr. 13(2): 444. 1849. Tipo: Brasil, "ad Bahia", Blanchet 1489 A (holótipo BM!). Syn. nov.

Pisonia heterophvlla Choisy in DC., Prodr. 13(2): 444. 1849. Tipo: Brasil, "ad Bahia", Blanchet 1489 B (holótipo BM!). Syn. nov.

Neea lanceolata Choisy in DC., Prodr. 13(2): 449. 1849. Tipo: Brasil, "prov. Rio de Janeiro ad Serra dos Orgaos", s.d., bot. est., Vauthier 80 (holótipo P!). Syn. nov.

Pisonia graciliflora var. subferruginosa Mart. ex J.A.Schmidt in Mart., FI. Bras. 14(2): 358. 1872, p.p. Tipo: Brasil, "in locis maritimis ad Ilheos", XII.1818, fl. est., Martius s.n. (lectótipo M!, aqui designado). Syn. nov.

Pisonia obtusiloba Huber, Bol. Mus. Paraense Emilio Goeldi, Bot. 5(2): 347. 1909. 三 Torrubia obtusiloba (Huber) Standl., Field Mus. Nat. Hist. Bot. 8(5): 308. 1931. इ Guapira obtusiloba (Huber) Lundell, Wrightia 4(2): 83. 1968. Tipo: Brasil, "Obidos, capoeira", 8.I.1904, fl. est., A. Ducke 4879 (lectótipo $\mathrm{BM}$ !; isolectótipo MG, aqui designados). Syn. nov.

Torrubia parvifolia Standl., Field Mus. Nat. Hist. Bot. 22: 18. 1940. इ Guapira parvifolia (Standl.) Lundell, Wrightia 4(2): 83. 1968. Tipo: Brasil, "São Paulo, Alto da Serra", M. Koscinski 162 (holótipo SP 31062; isótipo $\mathrm{F}$ frag.). Syn. nov.

Pisoniella apolinarii M. Lisboa, Escola de Minas e Metalurgia, Ouro Preto: 2. 1974. Tipo: Brasil, "in silvis ad Serra da Brigida prope Ouro Preto, MG, Augustsept.", Lisboa s.n., fl. est. (Lectótipo OUPR!, aqui designado). Syn. nov.

Fig. 23

Nomes vulgares: maria-mole (Hoehne s.n. SPF 15530); farinha-seca (T.S.Santos 3940; Hage 1225;
Froes 19955); ciriba (Martinelli 9956); pau-piranhabranco (Ferraz 56); cebola (Lisboa 1974).

Arbustos, arvoretas ou árvores, 0,5-25,0 m alt., às vezes ramificados desde a base, caule $3,0-54,5 \mathrm{~cm}$ diâm., fuste 1.5-12,0 m compr., cilíndrico, copa até $6 \mathrm{~m}$ diâm; ramos velhos lenhosos, cilíndricos, retos ou muitas vezes tortuosos, frequentemente dicotômicos, córtex cinéreo, áspero, glabros, lenticelados, às vezes enrugados quando secos; ramos novos carnosos, verdes a pouco vináceos, cilíndricos, retos, às vezes ligeiramente quadrangulares, ocasionalmente curtos, em geral folhosos e pouco desenvolvidos, glabros a esparsamente pubérulos ou hírtulos, quando secos pouco compressos, enegrecidos ou não; cicatrizes foliares até $2 \mathrm{~mm}$ diâm., salientes; entrenós 1,1-7,0 cm compr., normalmente apenas 2 entre cada ramificação, nós das ramificações com folhas ou cicatrizes verticiladas, nós não ramificados com folhas opostas ou subopostas, menos desenvolvidas que as verticiladas, ou raramente rudimentares; cicatrizes foliares ca. 1,0 mm larg., pouco salientes, gemas 0,5$1,5 \mathrm{~mm}$ larg., pouco pubérulo-ferrugíneas a amareladas. Folhas com pecíolos 0,3-2,6 cm compr., relativamente curto, frequentemente vináceos, glabros, às vezes os novos pouco pubérulos. Laminas (1,5-) $2,5-17,8 \times(0,7-) 1,1-6,1 \mathrm{~cm}$, opostas a subopostas, pares dos nós ramificados pouco desiguais geralmente em tamanho, pares dos nós não ramificados iguais ou às vezes menores e desiguais em forma e tamanho, elípticas, elíptico-lanceoladas a lanceoladas, muita vezes vezes ligeiramente obovadas ou largo-elípticas, base aguda, ápice agudo a obtuso, curto-acuminado, raramente longoacuminado, acúmen frequentemente obtuso, as menores dos pares medianos elípticas a orbiculares de base arredondada e ápice obtuso a arredondado, as adultas usualmente glabras, raramente tricomas esparsos embaixo ao lado da nervura mediana, cartáceas, ligeiramente discolores, mais escuras em cima, brilhantes especialmente em cima; quando secas cartáceas a membranáceas, verde-claras, verde-oliváceas a pardas, nervuras primárias $5-14$, oblíquas a patentes, pouco salientes nas duns faces, nervura coletora em geral recurvada e compressa; folhas novas às vezes avermelhadas, normalmente glabras, às vezes apenas nervuras pouco ferrugíneas embaixo, quando secas pardas a negras, em geral membranáceas, células com ráfides usualmente bem evidentes como pontos alongados mais claros. Inflorescências 1,8-10,6 x 0,9-8,2 cm, as pistiladas menores e menos ramificadas, terminais nos ramos novos e bifurcações, ou terminais em ramos curtos saindo de ramos já adultos, predominantemente verticilidas, ou subverticiladas as maiores e mais desenvolvidas, ocasionalmente um ramo alterno oblíquo pouco abaixo do verticilo, eretas ou frequentemente pêndulas, glabras ou tricomas ferrugíneos nas junções; pedúnculos 1,2-10,6 cm compr. $0,2-1,5 \mathrm{~mm}$ espessura, muitas vezes capiliformes, retos a curvos, verdes a comumente 


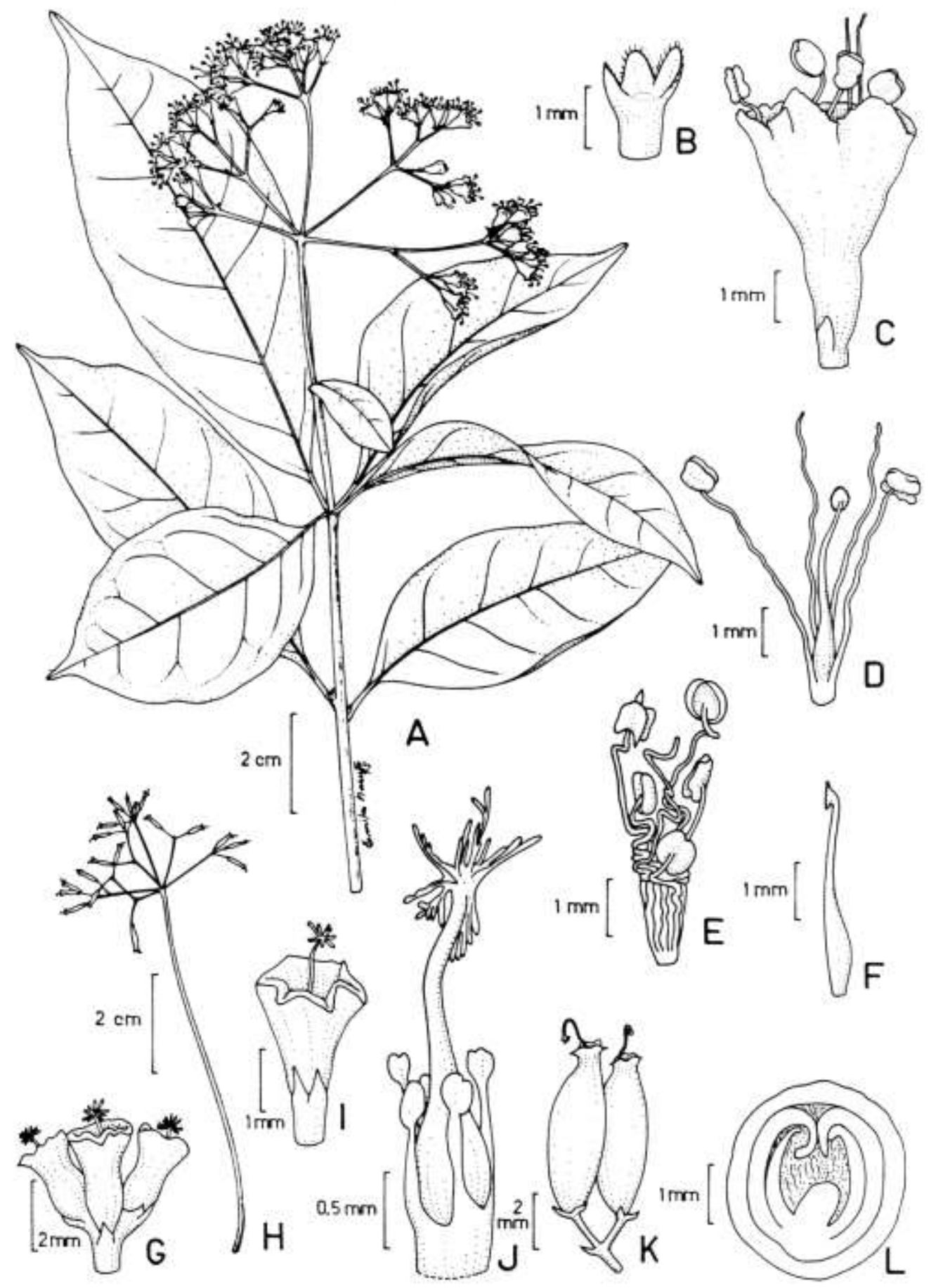

Fig. 23 - Guapira opposita: A. Ramo de planta estaminada. B. Brácteas e bractéolas. C. Flor estaminada. D. Estames e pistilódio. E. Disposição dos estames no botão. F. Pistilódio. G. Címula pistilada. H. Inflorescência pistilada. I. Flor pistilada. J. Gineceu e estaminódios. K. Antocarpos. L. Corte transversal do antocarpo e embrião, mostrando cotilédones enrolados lateralmente. (A - G.J. Shepherd et al. s.n. FUEL 1990; B-D, F - B. Rambo s.n., PACA 48979; E- P. Vinha 924; G, I-J - A.M. Carvalho et al. 2049; H - J.L. Hage \& E.B. Santos 788; K-L - A. Furlan et al. 511). 
rosado-vináceos; ramos primários 4-8, normalmente umbelado-verticilados, sem brácteas; ramos secundários quando presentes em geral verticilados a divaricados; cimeiras terminais trímeras, ramos laterais das címulas às vezes desenvolvidos até 4,5 $\mathrm{mm}$ compr., flor terminal da címula às vezes pedicelada até $0,4 \mathrm{~mm}$ compr.; brácteas na base dos ramos secundários e das címulas, $0,7-2,0 \times$ ca. 1,0 $\mathrm{mm}$, lineares a deltoides, pouco pilosa ferrugínea no ápice e nas margens; bractéolas 0,4-1,3 x 0,3-0,8 mm, deltoides a lineares, carnosas, glabras, ou ápice franjado-ciliado, ferrugíneo ou amarelado, em geral persistentes após a dispersão dos frutos; botões estaminados 1,5-5,0 x 1,0-2,0 mm, clavados a subcilíndricos, glabros ou poucos tricomas esparsos, filetes às vezes muito sinuosos; flores estaminadas 2,5-5,5 x 1,6-4,0 mm, afuniladas a campanuladas, base estreitada, verde-rosadas a amareladas, bordas ligeiramente vináceas, perfumadas; estames 5-10, salientes ca. $5,0 \mathrm{~mm}$, raro até $12 \mathrm{~mm}$, filetes verdeclaro, anteras creme, castanho-avermelhadas quando secas, pistilódio curto-estipitado; botões pistilados 1,5$2,5 \times 0,6-1,3 \mathrm{~mm}$, geralmente glabro; flores pistiladas $1,8-4,0 \times 0,8-2,2 \mathrm{~mm}$, glabras, tubulosas, pouco estreitadas no meio, tubo verde, ápice patente, róseovináceo, estigmas hemisférico-penicelados, brancos, salientes até $2,0 \mathrm{~mm}$, penicelado-aglomerados quando secos; estaminódios 4-8, pouco desenvolvidos. Infrutescências verticiladas a subverticiladas, 4,3-10,5 x 2,8-9,1 cm, normalmente glabras, lilás a vináceas, eretas ou geralmente pêndulas, pedúnculo 2,6-7,8 mm compr., carnosos, às vezes articulações estreitadas quando secas; ramos distais espessados, bractéolas em geral deflexas quando secas; antocarpos 4,0-12,0 $x$ 3,0-6,0 mm, globosos a oblongos, geralmente elipsoides, verde-róseos, amarelados, vermelhos, a negros quando maduros, suco avermelhado; coroa apical até $1,0 \mathrm{~mm}$ alt., aberta, pátula, às vezes não enegrecidas quando secas.

Reitz (1970) propôs o espécime A.P. Duarte 5021 (HB) do Rio de Janeiro como lectótipo de Torrubia opposita, porém deveria ser referido como neótipo, já que não fazia parte do protólogo. Contudo, como há uma ilustração associada ao protólogo, a mesma deve ser o lectótipo da espécie.

Bessera calicantha Vell. foi colocada por Reitz (1970) na sinonímia de G. opposita, e a ilustração de Vellozo aqui lectotipificada mostra que a sinonimização está correta.

A ilustração de Columella rustica Vell. não apresenta diferenças significativas em relação aos muitos espécimes estudados de $G$. opposita, especialmente aqueles coletados em áreas de dunas e praias, e por isso está sendo aqui sinonimizada.

Pisonia olfersiana foi descrita com base em uma planta cultivada nos jardins do Herbário de Berlin, proveniente do Brasil e introduzida no país pelo Sr. von Olfers. A ilustração e a descrição da planta indicam que está correta a sinonimização do binômio sob G. opposita, efetuada por Reitz (1970).
Pisonia minor foi caracterizada por Choisy (1849) como tendo as folhas pequenas com $3,5 \mathrm{~cm}$ de comprimento e verdes quando secas, A espécie foi sinonimizada neste trabalho porque os sintipos examinados enquadram-se bem na variação morfológica observada em G. opposita, onde plantas com folhas com esse comprimento não são raras. $O$ autor coloca na sinonímia de $P$. minor o nome descrito anteriormente Torrubia opposita Vell. Pisonia minor foi aqui lectotificado com Blanchet 3592, um exemplar estaminado como consta no protólogo, e com várias isolectótipos bem preservados.

Segundo Choisy (1845), Pisonia laxiflora teria como característica diagnóstica a inflorescência com pedúnculo e ramos das cimeiras terminais alongados. Embora com variações, muitos espécimes oriundos da bacia do Rio Doce exibem esses caracteres de modo pronunciado, e geralmente associados com as folhas verdes quando secas. Contudo, o exame de vultoso material de $G$. opposita revela que tais características ocorrem dispersas em indivíduos ao longo da distribuição da espécie sendo impossível distinguir os dois táxons. No mesmo trabalho Choisy (1845) descreveu $P$. comosa baseado no espécime Blanchet 1489- $A$, com flores pistiladas, e $P$. heterophylla baseada em Blanchet 1489-B, com flores estaminadas. Os espécimes são extremamente semelhantes, e não são distintos de G. opposita, tendo sido proposta a sinonimização.

Neea lanceolata foi descrita por Choisy (1849) com dúvidas no posicionamento genérico, aparecendo na descrição original "N.? lanceolata". O espécime Vauthier 80 , holótipo da espécie mostra os botões estaminados clavados, com ápices truncados, portanto iguais aos botões das espécies de Guapira. As folhas e inflorescências em Vauthier 80 são semelhantes aos de Pisonia laxiflora Choisy, descrita no mesmo trabalho. Heimerl (1897) já havia sugerido que esta planta poderia pertencer a $P$. laxiflora, mas não fez a sinonimização. Nesse trabalho as duas espécies estão incluídas na sinonímia de G. opposita.

Pisonia graciliflora var. subferruginosa foi descrita por Schmidt (1872) com base em cinco síntipos, que mostrou se tratarem de duas espécies distintas. Pisonia graciliflora var. subferruginosa p.p. tendo com lectótipo o espécime de Martius está sendo sinonimizado em $G$. opposita nesse trabalho, enquanto a outra parte da variedade que tem Burchell 5800 como lectótipo está sendo sinonimizada em G. graciliflora.

Pisonia obtusiloba foi caracterizada por Huber (1909) como possuindo inflorescência com pedúnculo filiforme e a forma dos lobos do perianto são truncados e largos. Em P. obtusiloba os sintipos Ducke 4879 e Black 47-2050 apresentam inflorescência subverticilada, com os ramos primários partindo quase do mesmo ponto e flores com desenvolvimento gradual. Em G. opposita, a presença de pedúnculo filiforme é bem e a forma dos lobos do perianto um carácter bastante variável na espécie. Apesar de espécimes com as características referidas para os 
sintipos de $P$. obtusiloba serem bastante raro em $G$. opposita, consideramos que pela coincidência nos demais caracteres, não se justifica o reconhecimento de duas espécies distintas. Como o espécime Ducke 4879 foi examinado apenas no Herbário BM, esse foi selecionado com lectótipo.

O holótipo de Torrubia parvifolia foi referido por Standley (1940) como a coleta de M. Koscinski 162, depositado em SP e considerado distinto das outras espécies do gênero pelas folhas muito pequenas $(1,5$ $2,5 \times 0,7-1,2 \mathrm{~cm}$ larg.), brilhantes e coriáceas. No Herbário SP tem a exsicata SP 31062, com a etiqueta mostrando a localidade de São Paulo, sem data e com coletor e número, mas sem o espécime. No Herbário SPSF tem uma exsicata com a etiqueta mostrando a localidade de Santos, SP, de agosto de 1938, coletada por M. Koscinski s.n. e identificada por Standley como T. parvifolia. Nessa exsicata está incluída um ramo e marcas na cartolina de um outro ramo. Nesse ramo as folhas atingem até $4,2 \mathrm{~cm} \times 1,5 \mathrm{~cm}$, incluindo-se portanto dentro da variabilidade de $G$. opposita, propiciando a sinonimização de $T$. parvifolia nesse trabalho.

Lisboa (1974) descreveu Pisoniella apolinarii, justificando a inclusão em Pisoniella pelas "flores hermafroditas". Porém, o material-tipo é composto de dois ramos, um de uma planta feminina e o outro de uma planta masculina, escolhido como lectótipo da espécie. Ambos em nada diferem dos espécimes examinados de $G$. opposita.

A ampla variabilidade morfológica de $G$. opposita leva à questão de uma possível conspecificidade entre esta espécie e G. guianensis Aubl., um nome anterior. Contudo, o exame do material-tipo desta (Herb. Jussieu 5170, ex herb.d'Aublet, P!, vide Howard 1983) mostra apenas infrutescências sem frutos, contudo diferentes das de G. opposita pelo tipo de ramificação, que é bifurcada, um caráter nunca observado em G. opposita. Além disso, suas folhas são largo-elípticas, grandes, com 7,9$14,2 \times 3,6-6,8 \mathrm{~cm}$, base aguda e inequilátera, glabras, de coloração marrom-escura e suas gemas são ferrugíneas escuras. Nenhuma outra espécie brasileira de Guapira assemelha-se ao tipo de G. guianensis.

Uma característica que pode ser observada nas folhas e flores de exemplares herborizados de $G$. opposita, quando não estão muito enegrecidos é a presença de pequenos traços claros que correspondem a células longas portando ráfides. Em um indivíduo de $G$. opposita, coletado em beira de praia, observou-se a presença de flores estaminadas e frutos, estes oriundos de uma florada anterior, indicando que houve alteração do sexo desse indivíduo no decorrer de sua existência. Em G. opposita pode ocorrer, muito raramente, plantas monóicas como observado nos espécimes Ribeiro 272 e Garcia 169. Nessa última planta ocorrem flores estaminadas e pistiladas em ramos diferentes da mesma inflorescência.

As plantas de $G$. opposita quando crescem à sombra e portam folhas ligeiramente maiores que as plantas expostas ao sol, e quando secam especialmente as mais novas tornam-se castanhas, diferentemente, as plantas expostas ao pleno sol, principalmente as que ocorrem em dunas, quando secam, inclusive as folhas jovens, permanecem com a cor verde-oliva. Em algumas etiquetas de herbário aparece anotado hábito semi-escandente ou apoiante, situação nunca observada na natureza, apesar de haverem sido encontradas árvores prostradas e rebrotando.

Distribuição geográfica e habitats (Fig. 24): G. opposita é a espécie do gênero com a maior área de distribuição, sendo encontrada em quase todos os estados do Brasil. O número de espécimes disponível evidencia também que é uma espécie facilmente encontrada, exceto na Amazônia. Ocorre em vários tipos de ambientes: restingas, dunas, praias, matas úmidas de restinga, manguezais, matas ciliares, matas de encosta, matas pluviais, brejos, sobre solos rochosos, matas semideciduais e até matas secundárias e capoeiras.

Material selecionado: Brasil. Alagoas: Quebrangulo, M.N.R. Staviski et al. 1087, 9.IV.1987, fl. est. (SPF). Amazonas: Vila lauareté, B.G.S. Ribeiro 975, 20.V.1975, infl. jovem (MG). Amapá: Macapá, J. Mattos et al. 10261, III.1962, fl. pist. (SP); Serra do Navio, R.S. Cowan 38223, 10.XI.1954, fl. pist. (NY, RB). Bahia: Itabuna, R. Callejas et al. 1570, 21.X.1983, fr. (CEPEC, MBM, SPF); Muritiba, Blanchet 3516 "Moritiba", 1842, fl. pist./fr. (BM, P, síntipo de P. minor Choisy). Ceará: Crato, T. Plowman et al. 12697, 19.I.1983, fl. pist. (F, K, RB); Fortaleza, E. Nunes s.n., 16.I.1984, fl. est., fr. (EAC 12284, SPF). Distrito Federal: Brasília, E.P. Heringer et al. 6788, 14.IV.1981, fl. est. (IBGE, MG, UEC). Espírito Santo: Aracruz, O.J. Pereira et al. 2504, 7.I.1992, bot. est. (SPF, VIES); Guarapari, J.A. Kallunki \& J.R. Pirani 343, 18.I.1993, fr. (NY, SPF). Goiás: Goiânia, J.A. Rizzo e A. Barbosa 2691, 4.XI.1968, fl. pist. (UFG). Maranhão: km 293 da BR-222, N.A. Rosa e H.Vilar 3041, 17.XII.1978, fr. (MG); São Luis, F.H. Muniz 214, 10.II.1993, fl. est. (HRCB). Minas Gerais: Belo Horizonte, H.S. Irwin et al. 30226, 13.I.1971, fr. (MBM, UB); Santana do Riacho, A. Furlan et al. CFSC 6085, 31.III.1980, fl. est. (K, SPF). Pará: Belém, P. Bamps 5116, 10.I.1976, fr. (BR); Bragança, A. Ducke 8884, 24.XI.1907, bot. est. (RB, síntipo de $P$. obtusiloba Huber). Paraíba: João Pessoa, C.A.B. Miranda 310, 31.III.1987, infl. jovem (JPB, SPF); Mamanguape, L.P. Felix et al. 3064, 24.V.1990, fl. pist. (JPB). Paraná: Antonina, G. Hatschbach 43964, 26.VIII.1981, fl. est. (MBM, UB); Guaratuba, P.I.S. Braga et al. 2345, 10.XII.1971, fr. (RB). Pernambuco: Floresta, E.P. Heringer et al. 950, 29.V.1971, fr. (ESA, IPA, R, RB, UB); També, Andrade-Lima 53-1664, 9.III.1953, fl. pist. (ESA, IPA, SPF). Rio de Janeiro: Bom Jesus de Itabapoana, C.M. Rizzini et al. 242, 16.X.1982, fl. pist. (GUA, UB); Casimiro de Abreu, P.P. Jouvin 423, 21.IIl.1979, fl. pist. (RB); Magé, C. Farney et al. 510, 19.X.1984, fr. (GUA, K). Rio Grande do Sul: Arroio do Sal, M.G. Rossoni 365, 18.III.1990, fl. pist. (ICN); Capão do Leão, J.A. Jarenkow 504, 9.XI.1986, fl. pist. (PEL, UEC). Rondônia: rio Pacaás Novos, Anderson 12323, 30.III.1978, fl. pist. (K). Roraima: Casa de Maracá, W. Miliken et al. 120, 28.IV.1947, fl. pist. (K); cordilheira Pacaraima, N.A. Rosa e O.C. Nascimento 3567, 27.IX.1979, fl. est. (MG). Santa Catarina: Camboriú, E. Pereira 8793, 31.I.1964, fl. est. (HB, M, RB); Itajaí, R. Klein 1571, 9.IX.1955, fl. pist. (BR, HB, K, SP). São Paulo: Botucatu, I. Gottsberger et al. 21-26974, 26.IX.1974, fl. est. (UB); Cubatão, O.T. Aguiar 379, 29.XI.1989, fr. (SP, SPF, SPSF). Tocantins: Ilha do Bananal, A.G. Andrade et al. 504, 


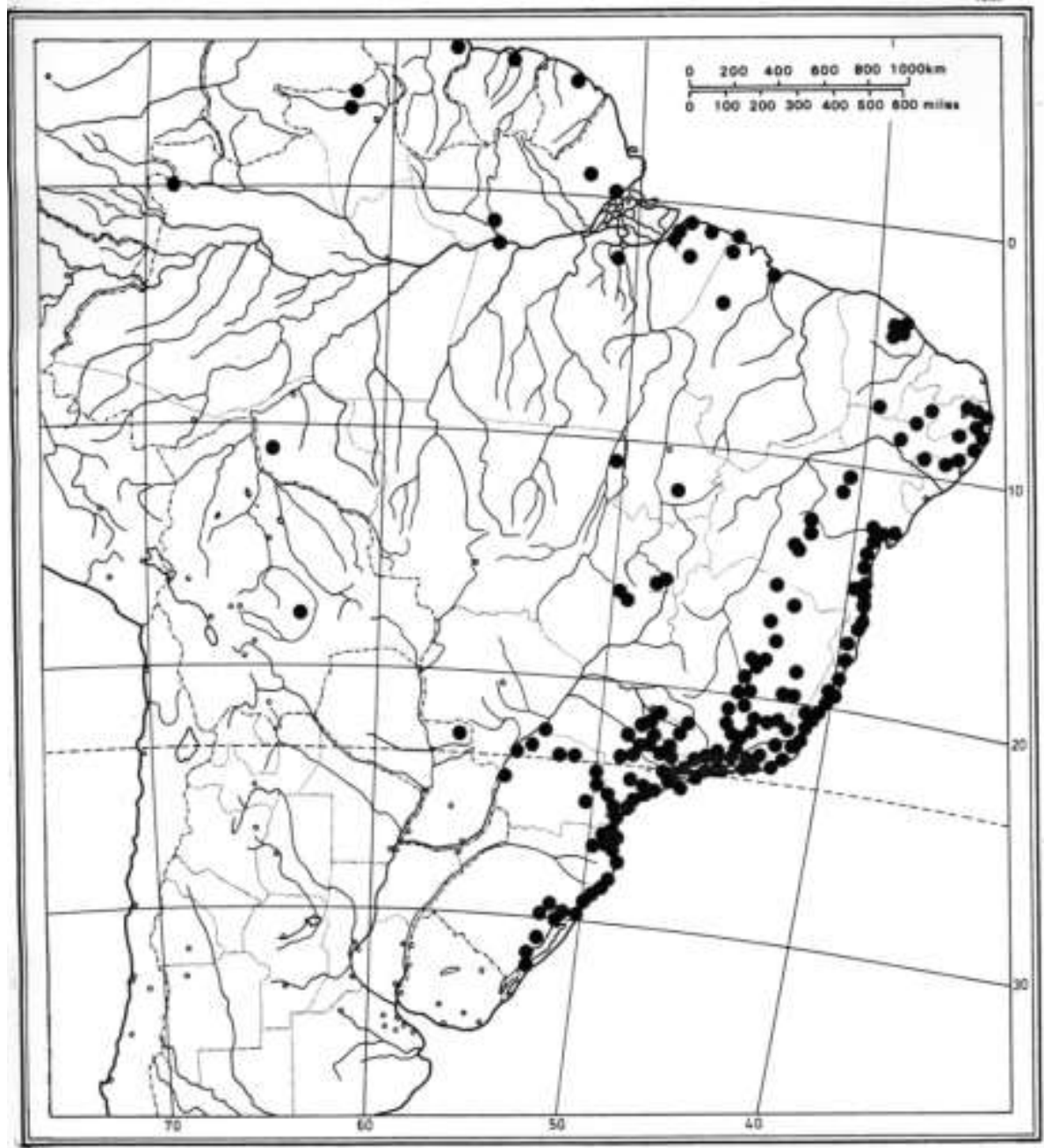

Fig. 24 - Distribuição geográfica de Guapira opposita no Brasil.

15.IX.1960, fl. est. (HB); Natividade, J.A. Rizzo \& A. Barbosa 2985, 5.XII.1969, fl. pist. (SPF, UFG).

Bolívia. C.Evrard 8527, 6.XI.1977, fl. pist. (BR).

Guiana. Georgetown, R.S. Cowan et al. 1933, 24.Il.1962, infl. jovem (K).

Guiana Francesa. Cayenne, R.S. Cowan et al. 38747, 12.XII.1954, fr. (P); H.S. Irwin et al. 47336, 3.VIII.1960, fl. pist. (K).

Paraguai. $22^{\circ} 40^{\prime} \mathrm{S}, \quad 56^{\circ} 05^{\prime} \mathrm{W}$, W. Hahn 1722 , 1.XI.1983, fr. (G, SPF).

Suriname. Paramaribo, J. Lanjou et al. 1042, 6.XI.1948, fl. est. (K).

1.10. Guapira pernambucensis (Casar.) Lundell, Wrightia 4(2): 83. 1968. E Pisonia pernambucensis Casar., Nov. stirp. bras. decas 8: 69. 1844. 三 Torrubia pernambucensis (Casar.) Standl., Contr. U.S. Natn. Herb. 18(3): 101. 1916. Tipo: Brasil, "prope civitas Pernambuco", G. Casaretto s.n. (holótipo, n.v.).

Pisonia cordifolia Mart. ex J.A. Schmidt in Mart., FI. Bras. 14(2): 359. 1872. Tipo: Brasil, "in maritimis inter
Rio de Janeiro et Bahia", s.d., fl. pist., Martius 2158 (lectótipo, M!; isolectótipos M! 3 exsicatas). Syn. nov.

Pisonia pernambucensis Casar. var. cordata Heimerl, Vidensk. Meddr. dansk naturh. Foren. 1890: 159. 1891. Tipos: Brasil, "ad Rio de Janeiro, ad Copacabana", 26.I.1870, Glaziou 4176, fl. est. (lectótipo P!, aqui designado).

Torrubia snethlagei Standl., Field Mus. Nat. Hist. Bot. 11(5): 153. 1936. Tipo: Brasil, Maranhão, São Luiz, 31.VII.1923, H. Snethlage (holótipo, F; isótipo B). Syn. nov

Torrubia loefgrenii Standl., Field Mus. Nat. Hist. Bot. 17(3): 243. 1937. E Guapira loefgrenii (Standl.) Lundell, Wrightia 4(2): 82. 1968. Tipo: Brasil, São Paulo, São Sebastião, 26.VII.1895, bot. pist., $A$. Loefgren (CGGSP 3061) (holótipo, F n.v.; isótipo SPF!). Syn. nov.

Fig. 25

Nomes vulgares: mangue (Krieger 10325); farinhaseca (Harley 18157); farinha-seca-do-litoral (L.A.M. Silva 806). 
Arbustos, subarbustos ou arvoretas, frequentemente escandentes, 1,0-4,5 $\mathrm{m}$ alt.; ramos escandentes ca. $1,5 \mathrm{~cm}$ diâm., alongados, delgados, irregulares; ramos terminais adultos lenhosos, cilíndricos, normalmente retos, em geral os mais basais dicotômicos, abertos em ângulo quase reto, os do alto mais fechados em ângulo agudo, usualmente ligeira predominância de um ramo em comprimento e espessura, às vezes com 4-5 nós sem ramificações; córtex cinéreo, finamente estriado, lenticelado; ramos novos, verdes, glabros, quando secos vináceos a paleáceos, usualmente pouco comprimidos e estriados, frequentemente subarticulados, meristema de abscisão mais escuro na base; entrenós 1,2-8,6 $\mathrm{mm}$ compr., às vezes aglomerados na base de ramos sem bifurcações; cicatrizes pouco salientes, hemiorbiculares; gemas pouco pilosas, tricomas curtos, ferrugíneos, adpressos, escamiformes. Folhas com pecíolo 0,1-6,0 mm compr., glabro, raramente os das folhas jovens pouco ciliados lateralmente. Laminas 2,5-20,1 x 1,8-7,2 cm, as da base em geral muito maiores que as distais, opostas, subamplexicaules, pares ligeiramente desiguais, cordiformes, oblongoorbiculares, oblongo-ovadas a ovadas, as menores do par sempre orbiculares, base cordada a arredondada, pouco inequilátera a atenuada desigualmente, ápice arredondado a obtuso, curto-acuminado, acúmen usualmente obtuso, raramente ápice emarginado, verde-glaucas, carnosas, glabras, raramente pouco pubérulas embaixo, brilhantes; quando secas cartáceas flexíveis, as adultas em geral castanhooliváceas, pouco brilhantes, as mais novas mais escuras, castanho- escuras a castanho-claras; nervuras até 9 de cada lado, salientes na face inferior, pouco salientes na face superior, em geral junções das nervuras elevadas na face superior, margem geralmente pouco recurvada, nervura coletora ligeiramente espessada. Inflorescências 3,3-6,2 x 1,6$4,5 \mathrm{~cm}$, hemisféricas, usualmente terminais no ramo do ano, muitas vezes nas bifurcações, eretas, verticiladas, glabras ou às vezes com poucos tricomas ferrugíneos nas articulações; pedúnculo 1,2-3,5 cm compr., até 1,3 $\mathrm{mm}$ espessura, ramos primários 4-5, patentes, ramos secundários quando presentes alternos a verticilados; cimeira terminal em geral trímera, ramos laterais não ou pouco desenvolvidos até $0,5 \mathrm{~mm}$ compr., as pistiladas mais aglomeradas, até 7 flores no ápice; brácteas das címulas 0,7-1,2 $\mathrm{x}$ ca. $0,8 \mathrm{~mm}$, deltoides, ápice obtuso, glabras a pouco ciliadas; bractéolas 0,4-0,8 x ca. 0,5 mm, hemisféricas a deltoides, ápice arredondado, glabras ou pouco pubérulas, às vezes ciliadas; botões estaminados 2,0$3,2 \times 1,5-2,0 \mathrm{~mm}$, curto-clavados, glabros a pouco ferrugíneos na base; flores estaminadas 2,5-4,0 x 2,0$2,5 \mathrm{~mm}$, clavadas a campanuladas, lobos do cálice às vezes patentes, verde-amarelados, ápices avermelhados, em geral glabras ou com poucos tricomas na base; estames 6-9, salientes até $3 \mathrm{~mm}$; pistilódio às vezes com estigma pouco lacerado; estames e pistilódio ligeiramente estipitados; botões pistilados 1,5-2,0 x 1,0-1,5 mm, oblongos, constrictos perto do ápice; flores pistiladas 1,5-2,0 x 1,0-2,0 mm, verdes, carnosas, fauce às vezes bem aberta, patente; estigma branco, saliente até $1,0 \mathrm{~mm}$; estaminódios 58; ovário e estaminódios ligeiramente estipitados. Infrutescências 3,5-7,0 x 2,0-5,0 cm, em geral nas bifurcações, globosas, verticiladas, glabras; pedúnculo 2,5-3,5 cm compr., espessado até $1,5 \mathrm{~mm}$, ereto, inflexível; antocarpos 4,0-7,0 x 3,5-5,0 mm, frequentemente globosos a pouco oblongos, glabros, brilhantes, os imaturos amarelos, vermelhoalaranjados a vináceos, os maduros negros, costados quando secos; coroa apical $0,5-1,0 \mathrm{~mm}$ alt., ereta ou pouco patente; estaminódios pouco desenvolvidos.

O protólogo do Pisonia pernambucensis apresentado por Casareto (1842) é uma boa descrição da espécie que permite a identificação da mesma, mesmo sem ter conseguido localizar e examinar o espécime-tipo. Essas identificações foram confirmadas pelo exame de espécimes identificados por Heimerl, como Gaudichaud 407 e por Westra como Martius 2158, Glaziou 1360 e Burchell 2886. A boa descrição da espécie certamente tem ajudado nas corretas identificações verificadas na maioria dos herbários.

Pisonia cordifolia foi descrita por Schmidt (1872) baseando-se em dois sintipos coletados por Martius s.n. Nesse trabalho foi selecionado como lectótipo o material coletado entre Rio de Janeiro e Bahia, que possui três isolectótipos depositados em M. Todos os espécimes examinados são muito similares entre si, e aos demais materiais examinados de $G$. pernambucensis, razão da sinonimização aqui proposta.

Heimerl (1891) descreveu Pisonia pernambucensis var. cordata com base em três sintipos, dos quais Warming \& Lund s.n. não foi examinado. Os outros síntipos, Glaziou 1360 (fl. pist.) e Glaziou 4176 (fl. est.),foram coletados também no Rio de Janeiro, nesse caso na praia de Copacabana, e ambos apresentam folhas sésseis orbiculares a oblongo-orbiculares de base arredondada, portanto inseridos na variabilidade de $G$. pernambucensis, sendo impossível separá-los como uma variedade distinta. Foi escolhido como lectótipo o espécime de flores estaminadas.

Torrubia loefgrenii foi proposta por Standley (1937) com base em espécime da restinga de São Paulo, que apresenta as folhas com dimensões bem maiores que a maioria dos materiais estudados de $G$. pernambucensis. Porém, a variabilidade das dimensões foliares que são muito maiores em plantas com ramos escandentes, dentro do emaranhado de vegetação arbustiva das restingas como observado no estado da Bahia, ajudaram na decisão da sinonimização de $T$. loefgrenii.

Choisy (1849) cita no material examinado de Pisonia subcordata Sw., os seguintes espécimes coletados no Brasil, Gaudichaud 406, Blanchet 1951, 3526 e Gardner 1387 que devem ser redeterminados como G. pernambucensis e Gaudichaud 408 que deve ser incluído em G. obtusata. As três espécies são distintas, pois enquanto $P$. subcordata possui antocarpos secos e glandulosos, característicos do 


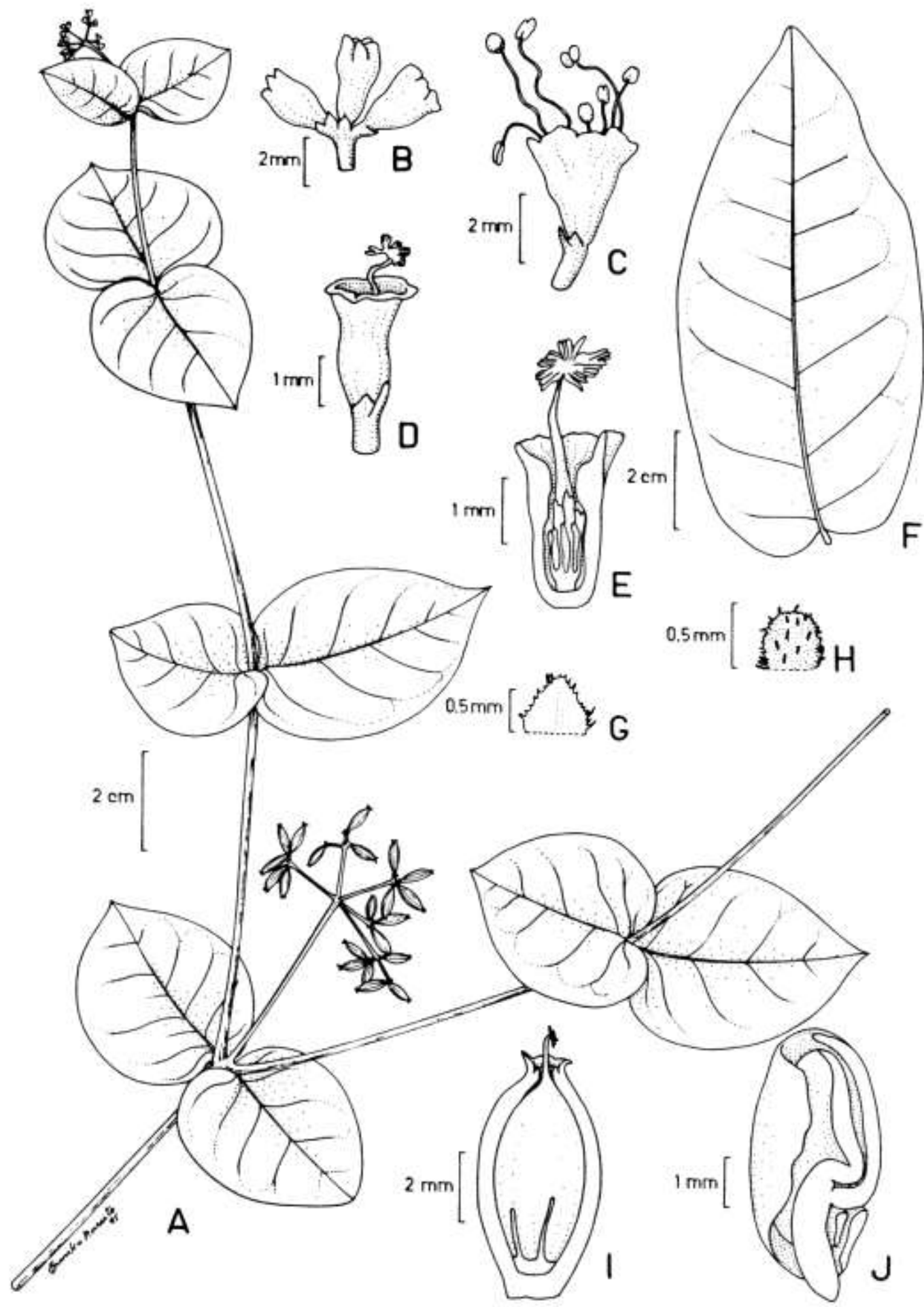

Fig. 25 - Guapira pernambucensis: A. Parte de um ramo escandente com infrutescências e inflorescência jovem. B. Címula jovem com botões truncados. C. Flor estaminada. D. Flor pistilada. E. Flor pistilada com cálice em corte longitudinal. F. Folha. G. Bráctea das címulas, face ventral. H. Bractéolas, face dorsal. I. Fruto e estaminódios, com o antocarpo em corte longitudinal. J. Embrião em corte longitudinal. (A - M.F. Agra 109; B-C - A.M. Carvalho et al. 1233; D-E, G-H - F.S. Santos 244 ; F - A. Loefgren CGGSP 3061, tipo de T.loefgrenii Standl.; I-J - A.M. Carvalho et al. 3312). 
gênero Pisonia, os espécimes referidos possuem antocarpos característicos de Guapira. No descrição $P$. subcordata apresentada por Choisy (1849) é mencionado "Fruto elíptico estriado com ângulos muricados" e restringe a espécie ao Caribe e América Central. Para esse trabalho foram examinados espécimes coletados em Sto. Thomas (Eggers 378, BR, M, P), em Guadalupe ( $P$. Duss 589, P), na Martinica (Plee 856, P; A. Questel 233, P) e em Porto Rico (Herb. Jussieu 4630, P; P. Sintenis 5669, P), os quais concordam plenamente com a caracterização de $P$. subcordata. Schmidt (1872) também citou $P$. subcordata para o Brasil, acrescentando aos espécimes referidos por Choisy (1849) o espécime coletado por Burchell 2886, o qual deve ser também identificado como G. pernambucensis. Esse problema de incorreta identificação já havia sido comentado por Heimerl (1901), que ressaltou as fortes diferenças entre Pisonia pernambucensis e $P$. subcordata e afirmou que a descrição apresentada por Choisy (1849) seria uma mistura de exemplares de ambas espécies, sendo uma do Brasil e a outra do Caribe, atualmente pertencentes a gêneros distintos.

Standley (1936) descreveu Torrubia snethlagei baseado em dois espécimes coletados nas restingas de São Luiz no Maranhão e que seriam distintos das outras espécies do gênero, por apresentarem as folhas sésseis, ovadas a arredondadas e base cordada, e pela textura carnosa e consistência coriácea. Apesar desses espécimes não terem sido examinados, a descrição da mesma, corroborada pela procedência de restinga, indicam que se trata de um sinônimo de G. pernambucensis, que ocorre na área litorânea do Maranhão até São Paulo.

Das espécies de Guapira com folhas sésseis de base cordada, G. pernambucensis se diferencia de G. campestris pela inflorescência com ramos verticilados, distinta da inflorescência com ramos opostos oblíquos ou dicotômicos em G. campestris.

É muito comum em $G$. pernambucensis a ocorrência de botões estaminados portando galhas, esses são mais globosos na base, alcançando $3,0 \mathrm{~mm}$ de diâmetro, parecendo uma flor estaminada de Neea, exceto pelo ápice truncado.

Distribuição geográfica e habitats (Fig. 26): concentrada ao longo da linha litorânea, desde São Luiz no Maranhão até seu limite sul na llha do Cardoso, São Paulo, onde fica bem menos comum. Habita em praias, restingas, dunas, ilhas, matas de restinga, manguezais e pode ser ocasionalmente ser encontrada no interior de mata ombrófila litorânea.

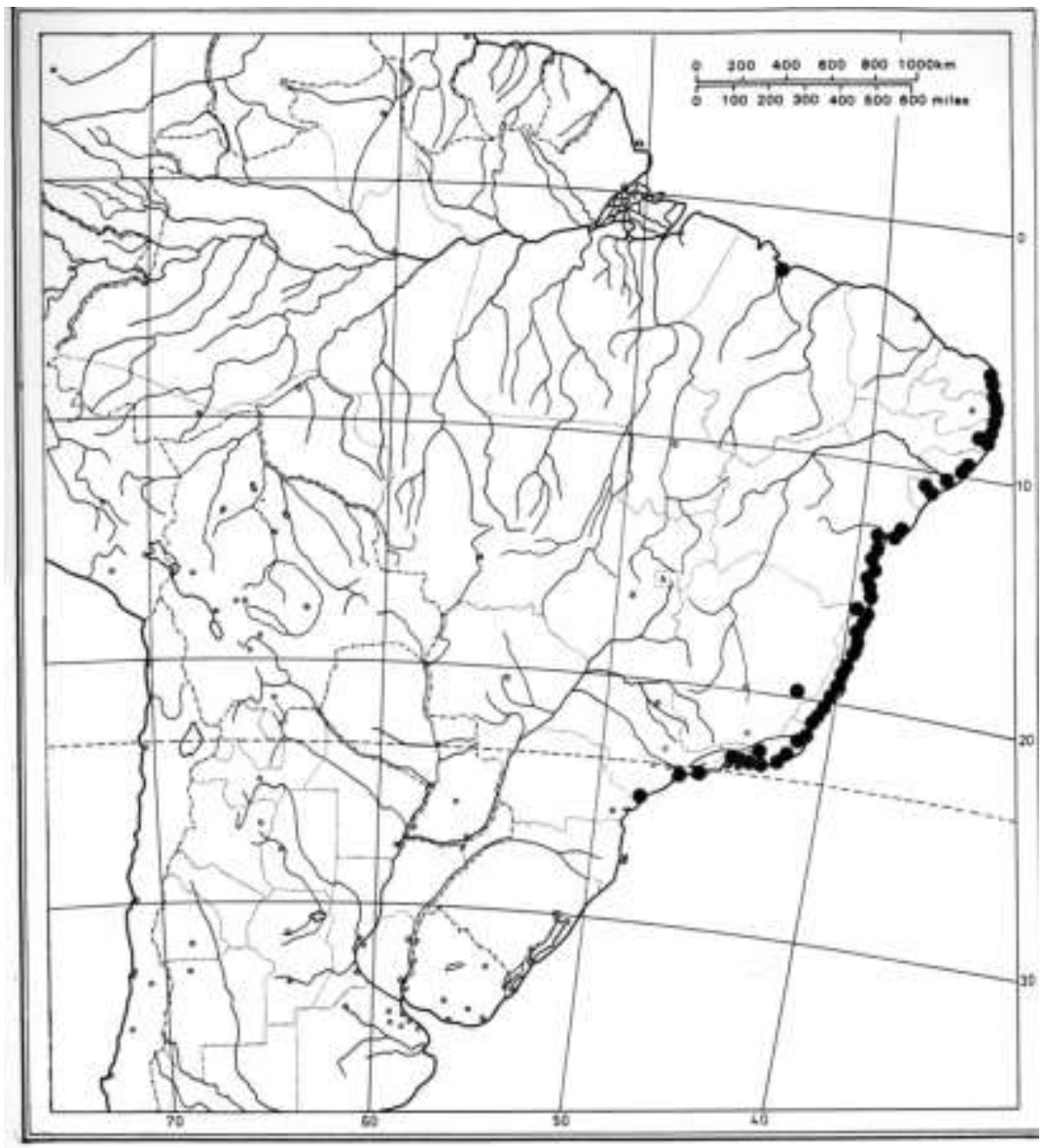

Fig. 26 - Distribuição geográfica de Gupaira pernambucensis. 
Material selecionado: Brasil. Alagoas, Maceió, J.R. Pirani \& J.A. Kallunki 2674, 26.I.1993, fr. (NY, SPF). Bahia, Belmonte, R.M. Harley 17409, 25.III.1974, fl. pist. (CEPEC, K, RB); Camaçari, H.P. Bautista 548, 25.X.1982, fl. pist./fr. (HRB, HUEFS, ICN, R, RB). Espírito Santo: Cariacica, G. Hatschbach e J.M. Silva 48779, 10.XII.1984, fl. est./fr. (MBM); Conceição da Barra, H.C. Lima 2969, 14.V.1987, fr. (GUA, RB). Maranhão: São Luís, Marques et al. 93, 15.III.1989, bot. pist./fr. (HRCB). Minas Gerais: Caratinga, I.R. Andrade et al. 156, 11.X.1987, fl. est. (BHCB). Paraíba: Cabedelo, M.F. Agra 109, 15.I.1979, fr. (JPB, SPF). Pernambuco: Goiana, M.L. Guedes \& M.D.B. Moura 1714, 9.V.1989, fr. (ESA); Itamaracá, F. Gallindo 155, 14.I.1986, fr. (IPA). Rio de Janeiro: Maricá, V.L.G. Klein et al. 224, 5.III.1985, fr. (RB). Rio Grande do Norte: Natal, D. Araujo 7623, 28.IX.1986, fl. pist. (GUA). São Paulo: Cananéia, J.R. Pirani et al. 2034, 5.XII.1987, fl. pist. (SPF). Sergipe: Aracaju, F. Barros 2416, 22.I.1992, fl. pist. (SP); Serra da Itabaiana, Herb. Condesse 12, XII.1975, infl. jovem, (RB).

1.11. Guapira tomentosa (Casar.) Lundell, Wrightia 4(2); 84. 1968. झ Pisonia tomentosa Casar., Nov. stirp. bras. decas 8: 69. 1844. E Torrubia tomentosa (Casar.) Standl., Contr. U.S. Natn. Herb. 18(3): 101. 1916. Tipo: Brasil, "in prov. Minas Geraes", Claussen s.n. (holótipo, n.v.).

Fig. 27

Arbustos a arvoretas escandentes, 0,8-2,0 m alt., ramificação di-tricotômica; ramos adultos lenhosos até $6,0 \mathrm{~mm}$ diâm., tomentoso a hírtulo-esparso, ramo principal frequentemente de crescimento indeterminado, ramos laterais alternos ou em geral opostos, usualmente todos retos, eretos, não compressos, às vezes pouco estriados; ramos novos densamente hírtulos, pouco a muito estriados quando secos; entrenós 1,5-6,2 mm compr., raramente ca. 1,1 $\mathrm{mm}$ compr. em ramos novos, 2-4 entre cada ramificação em ramos dicotômicos; cicatrizes foliares até 1,3 mm largura; gemas 0,3-0,8 mm larg., marrons, pouco visíveis, denso-pilosas. Folhas com pecíolo $3,0-$ $11,0 \mathrm{~mm}$ compr., piloso-hírtulo. Laminas 3,2-11,2 x1,3$4,4 \mathrm{~cm}$, comumente as basais maiores, alternas na região basal, opostas na região apical, elípticas a oblongo-elípticas, as maiores em geral ligeiramente obovadas a elíptico-obovadas, base aguda atenuada a raramente obtusa, ápice agudo curto-acuminado, raramente obtuso a arredondado, as menores do par em geral orbiculares a elípticas; superfícies elevadas entre as nervuras principais, margens em geral bem revolutas especialmente na região basal, raramente pouco revolutas; quando secas cartáceas e flexíveis, face superior preta a marron-escuro, brilhante ou opaca, nervuras impressas marrom mais claro, tricomas hírtulos, menos condensados do que na face inferior, exceto na região mediana, logo decíduos permanecendo a base do tricoma, o que torna a superfície áspera, face inferior opaca, geralmente não enegrecida, nervuras pouco salientes, não tomentosa, densos tricomas hirtos, eretos, concentrados na nervura mediana, tricomas até $1,0 \mathrm{~mm}$ comp., unisseriados, raramente ramificados perto do ápice, célula apical vermelho-amarelada nas folhas jovens, vermelho-escura a marrom nas folhas velhas. Inflorescências $0,9-2,2 \quad(-3,2) \times 0,5-1.5 \quad(-2,7) \mathrm{cm}$, geralmente aglomeradas, subcapituliformes, raramente pouco laxas, axilares e terminais, densopilosas, poucas flores, flores em geral desenvolvidas gradualmente, flores estéreis às vezes presentes; pedúnculo $0,5-1,2 \quad(-2,2) \quad \mathrm{cm}$ compr.; ramos verticilados, desiguais, às vezes dois maiores e dois menores, raramente um ramo alterno abaixo do verticilo; brácteas 1,0-2,8 x ca. 1,0 mm, na base dos ramos, oblongas, ápice geralmente obtuso, pilosas nas duas faces, internamente no ápice; bractéolas 0,6$1,0 \times$ ca. $0,5 \mathrm{~mm}$, deltoides, extemamente pilosas; botões estaminados 1,8-3,2 x 1,0-1,8 mm, curtoclavados, pilosos, tricomas hírtulos a ligeramente adpressos, ferrugíneos a pardos, mais concentrados na base; flores estaminadas 2,0-3,5 x 2,0-2,4 mm, campanuladas, não estreitadas na base, lobos apicais curto-denteados, não reflexos, avermelhadas, pubérulas, tricomas mais concentrados na base, às vezes até o ápice; estames $6-8$, salientes até $2,8 \mathrm{~mm}$; anteras ca. 0,5 mm compr.; botões pistilados ca. $1,5 \mathrm{x}$ $1,0 \mathrm{~mm}$, denso-pilosos; flores pistiladas 1,5-2,5 x 0,8$1,5 \mathrm{~mm}$, campanuladas, não estreitadas extemamente, pouco mais pubérula que as estaminadas; estaminódios em geral 7, estigma saliente até $1,1 \mathrm{~mm}$. Infrutescências $1,3-4,1 \times 0,7-3,6 \mathrm{~cm}$, em geral aglomeradas; pedúnculo 0,8-2,1 $\mathrm{mm}$ compr., irregularmente verticilado no ápice, ramos pouco desenvolvidos, brácteas dos ramos persistentes; antocarpos 5,5-10,0 x 2,5-5,0 mm, oblongos, vermelhos a negros, ligeiramente pedicelados, pedicelos $1,5 \mathrm{~mm}$ compr., pouco espessado acima das bractéolas reflexas; tricomas poucos, esparsos na base, pouco mais densos no ápice; coroa $0,5 \mathrm{~mm}$ alt., até $1,5 \mathrm{~mm}$ larg., ereta a fechada, raramente pouco pátula, sub-hírtula; estigma saliente até $1 \mathrm{~mm}$, ou em geral recurvado para dentro da coroa.

Segundo Casaretto (1842), Pisonia tomentosa foi baseada em Claussen s.n. de Minas Gerais e seria caracterizada por apresentar ramos di-tricotomicos, hírtulos, com folhas curto-pecioladas, largo-oblongas, com margem sempre revoluta, face superior infladobulada e a inferior rufo-tomentosa, inflorescência com cimeiras curto pedunculadas e flores pouco compactadas. Nos herbários visitados apesar de estarem disponíveis vários espécimes de Claussen s.n., nenhum se enquadra na descrição apresentada para $P$. tomentosa. Assim, a identificação de espécimes como $G$. tomentosa foi feita através da descrição original de Casaretto (1842) e posteriormente comparada com espécimes incluídos nessa espécie. Heimerl (1891 cita como P. tomentosa o material Glaziou 15351, porém este autor colocou $P$. hirsuta Choisy como sinônimo da espécie. Esse mesmo espécime foi identificado em herbário por Schmidt como $P$. hirsuta mas está nesse trabalho identificado como $G$. tomentosa. Dentre os materiais citados por Choisy (1849) e Schmidt (1872) para $P$. tomentosa Casar., foram examinados, Blanchet 3772 redeterminado como Guapira laxa (Netto) Furlan e 

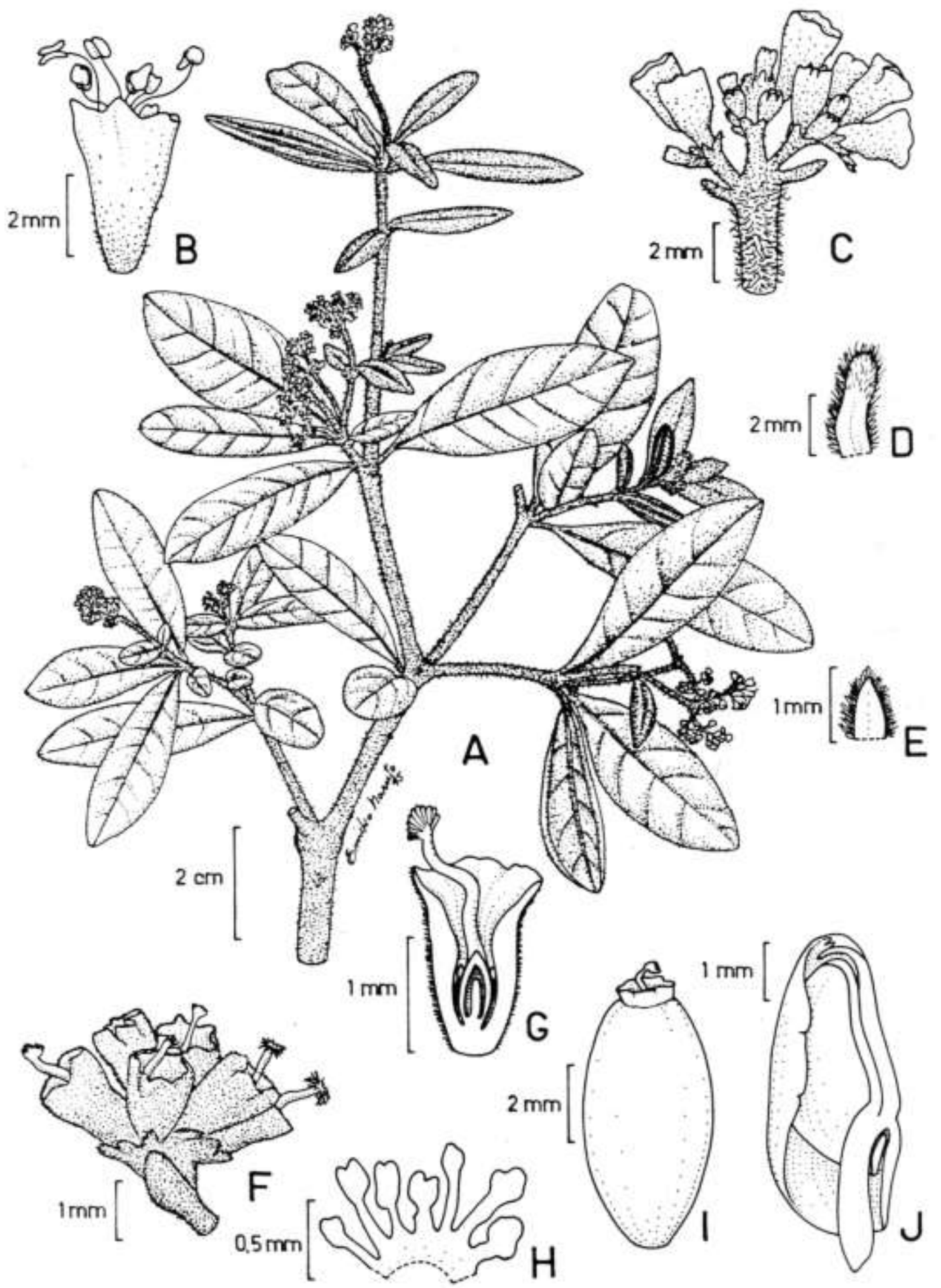

Fig. 27 - Guapira tomentosa: A. Ramo de planta estaminada. B. Flor estaminada em antese. C. Inflorescência estaminada jovem. D. Bráctea dos ramos da inflorescência, face ventral, pilosa em ambas faces. E. Bractéolas. F. Inflorescência pistilada. G. Flor pistilada em corte longitudinal. H. Anel de estaminódios, aberto e rebatido. I. Antocarpo. J. Embrião em corte longitudinal. (A-E - L. Roth s.n. CESJ 1506; F-H - M. Barreto 7225). 
Burchell 6024 redeterminado como G. noxia (Netto) Lundell. Esses dois espécimes se enquadram bem nas espécies em que foram incluídos por apresentarem inflorescências não verticiladas, bem diferentes de $G$. tomentosa e de $G$. hirsuta.

A sinonimização de $P$. hirsuta em $P$. tomentosa por Heimerl (1891) provavelmente foi baseada na presença de pilosidade evitente nas duas espécies. Porém, em Guapira hirsuta as folhas são geralmente lanceoladas, com margem plana e superfície não bulada, e as as inflorescências são geralmente pedunculadas e laxas ao contrário de $G$. tomentosa que possui as folhas com forma variável entre cordiformes a ovadas, com margem revoluta e superfície bulada e as inflorescências são aglomeradas, sub-capituliformes, com pedúnculo muito curto.

Em algumas flores estaminadas de $G$. tomentosa foi observado que apesar das mesmas apresentarem formas e tamanhos normais, ao serem dissecadas estavam vazias, e em outras flores estaminadas, os estames mostravam uma excrescencia semelhante a um pequeno pistilódio, desenvolvido no final dos filetes.
Distribuição geográfica e habitats (Fig. 28): G. tomentosa ocorre em campo pedregoso, e em campo rupestre em transição para a mata ou cerrado sobre "canga". É espécie tem distribuição restrita, com coletas no Espírito Santo, Rio de Janeiro, Minas Gerais, principalmente na região de Belo Horizonte.

Material examinado: Brasil. Espírito Santo: Santa Teresa, W.A. Hoffinann 208, 17.X.1984, fl. pist. (SPF). Minas Gerais: Belo Horizonte, L. Roth s.n., VIII.1954, fl. est./fr. (CESJ 1506, SPF); Betim, L. Renno s.n., 1970, fl. est. (BHCB 1237); Caeté, M. Barreto 5410, 28.VI.1933, infl. jovem (BHCB, R); idem, M. Barreto 7225, 24.IX.1936, fl. pist. (HE, R); idem, J. Paula et al. 1928, 28.IX.1985, fl. pist. (BHCB, FCAB); Itabirito, S.A. Souza s.n., 14.XI.1987, fr. (BHCB 11437); São Gonçalo do Rio Abaixo, G. Pedralli et al. s.n., 1.XII.1987, bot. est./fr. (I-DCBH 7421, HXBH 7422); idem, G. Pedralli s.n., 30.IX.1987, fl. est. (HXBH 7423, 7424, 7425 e 7426); Serra da Piedade, A. Glaziou 20433, IX.1893, fr. (K, P); Serra das Canarinhas, Schwacke 11578, VIII.1893, estéril (RB); Serra do Caraça, A. Glaziou 15351, 14.VI.1884, fl. est./fr. (BR, K, P); Serra do Cipó, Schwacke 11751, VIII.1895, bot. est. (P); sem local, Ackerman s.n., s.d., fl. pist. (BR). Rio de Janeiro: Nova Friburgo, A. Glaziou s.n., 22.X.1884, infl. jovem (P); idem, J.C. Siqueira et al. 2133, 6.IX.1986, fl. est. (FCAB); idem, L.A.O. Torres \& S.F. Rocha 63, 15.XI.1981, fl. pist./fr. (GUA).

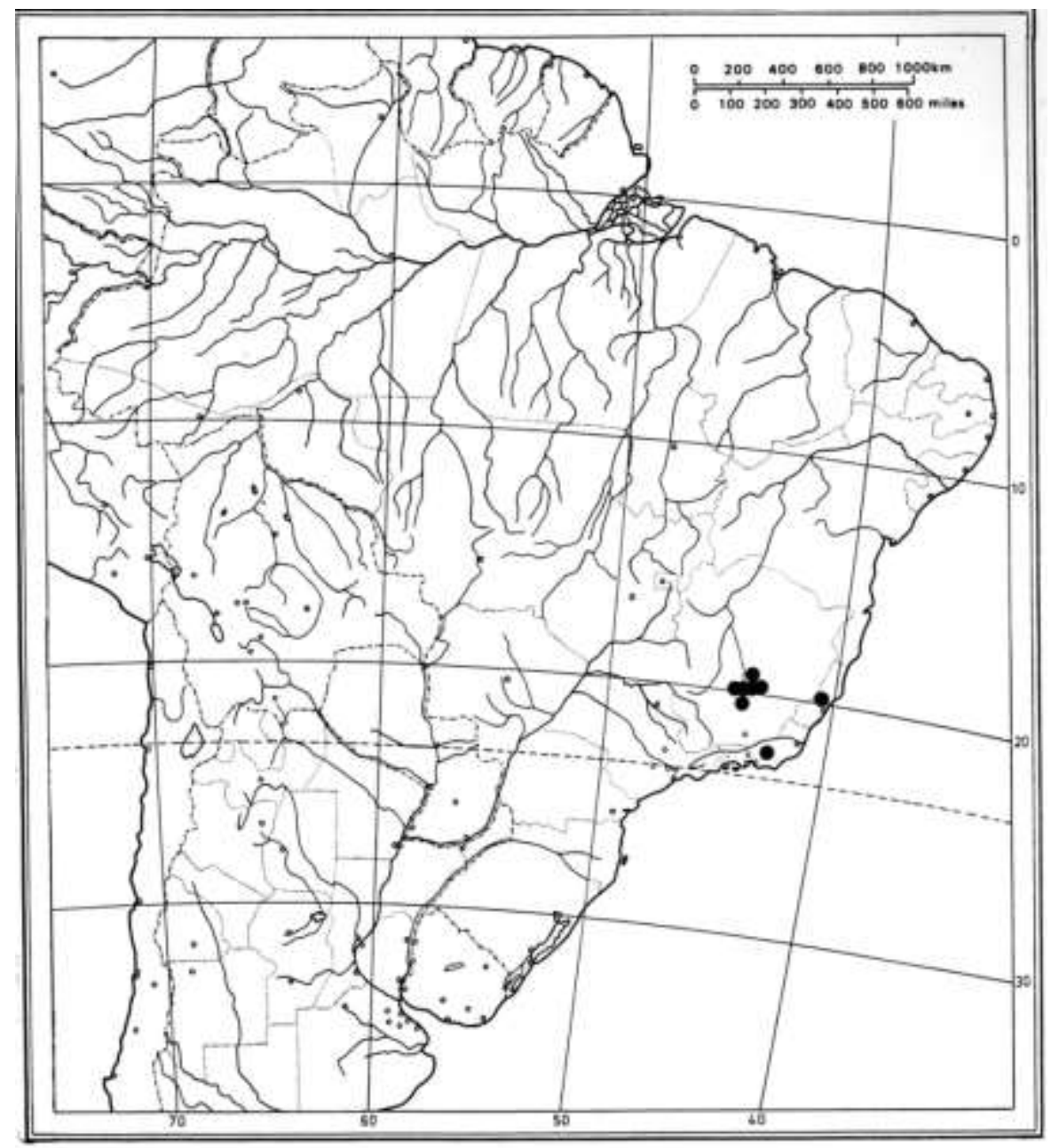

Fig. 28 -Distribuição geográfica de Guapira tomentosa. 
1.12. Guapira venosa (Choisy) Lundell, Wrightia 4(2): 84. 1968. = Pisonia venosa Choisy in DC., Prodr. 13(2): 444. 1849. इ Torrubia venosa (Choisy) Standl., Contr. U.S. Natn. Herb. 18(3): 101. 1916. Tipo: Brasil, "ad Bahiam", 1857, fl. est./fl. pist., Blanchet 3972 a (lectótipo P, fl. pist.!) aqui designado. (Outro síntipo, Blanchet 3972 b, BR!, K!, fl. est. jovens).

Fig. 29

Arbustos a geralmente árvores, 3,0-25,0 m alt., caule 0,3-1,2 m diâm.; ramos lenhosos, cilíndricos, não compressos, os distais quando secos pouco enrugados, pouco flexíveis, cor creme, não enegrecidos, pouco estriados, lenticelas até $2 \mathrm{~mm}$ compr.; entrenós 0,9-11,2 cm compr., em geral 2-3 entre cada ramificação; cicatrizes alongadas, frequentemente com células com ráfides visíveis como pontos brancos, às vezes várias gemas acima da cicatriz e alinhadas longitudinalmente. Folhas com pecíolo 0,9-2,2 cm compr., 1,9-3,2 mm espessura, em geral negro quando seco, às vezes corticado ou com lenticelas transversais. Laminas 11,1-22,6 x 5,2-12,6 $\mathrm{cm}$, opostas ou subopostas, pares usualmente iguais, elípticas, oblongo-obovadas, raramente ovadas, base aguda larga, obtusa, a arredondada, às vezes muito inequilátera, ápice agudo a obtuso, curto-acuminado a caudado, em geral as menores do par orbiculares a obovadas de ápice arredondado, glabras, quando secas pardas a ocráceas, face inferior mais clara, face superior com nervuras não salientes, face inferior com nervuras salientes especialmente a nervura mediana, cartáceas, firmes, as mais velhas subcoriáceas, às vezes brilhante nas duas faces, ou pouco menos na face inferior; folhas jovens pubérulas, ferrugíneoamareladas, tricomas curtos e adpressos mais condensados na nervura mediana e nas margens, elípticas, irregulares, pretas quando secas. Inflorescências 3,5-15,0 x 3,1-15,2 mm, principalmente em ramos velhos, menos frequentes nos ápices dos ramos, às vezes até 3 inflorescências no mesmo nó, pouco pubérulas, tricomas curtos, ferrugíneoamarelados, esparsos; pedúnculo 0,8-5,5 cm compr., $1,2-2,5 \mathrm{~mm}$ espessura, glabro, ramos opostos a subopostos, raramente alternos ou subverticilados, ramos finais racemosos, geralmente flores em grupos de 3 , dispostas de forma racemosa no ramo final mais alongado, bem evidentes na frutificação, menos frequentemente flores aglomeradas nos ápices dos ramos distais; brácteas deltoides, 0,6-1,2 x ca. 1,0 $\mathrm{mm}$, na base dos ramos distais; bractéolas 0,5-0,8 $\mathrm{x}$ ca. $0,5 \mathrm{~mm}$, margem às vezes fimbriada; botões estaminados 1,9-4,1 x 1,0-1,8 mm, clavados, glabros, bem estreitados na base, os muito jovens de ápice arredondado, base amarelada, ápice avermelhado, anteras geralmente já deiscentes; flores estaminadas 3,0-4,9 x 2,5-3,2 mm, campanulada, verde-claras, ligeiramente perfumadas, estames 7-9, salientes até $5,8 \mathrm{~mm}$, filetes brancos, pistilódio às vezes saliente até $0,6 \mathrm{~mm}$; botões pistilados ca. $2,5 \times$ ca. $1,5 \mathrm{~mm}$, tubulosos, pouco pulverulentos; flores pistiladas 1,5 $3,6 \times 0,8-1,3 \mathrm{~mm}$, tubulosas, verde a creme, estigma saliente até 1,8 mm. Infrutescências 3,2-7,9 x 2,5-5,6 cm; pedúnculo 1,5-8,7 cm compr., espessado na base, em geral com gemas ao lado do espessamento, ramos distais espessados até $2,4 \mathrm{~mm}$ largura, pedicelo do fruto às vezes alongado até $1,6 \mathrm{~mm}$ acima das bractéolas; antocarpos 7,2-12,0 x 4,5-9,5 mm, às vezes muito carnosos e enrugados quando secos; coroa $0,3-1,8 \mathrm{~mm}$ alt., ereta a pátula, às vezes pouco imersa, estigema saliente até $1 \mathrm{~mm}$; cotilédones muitas vezes bem convolutos.

Guapira venosa é muito peculiar dentro do gênero, pela ocorrência frequente de caulifloria, caráter que ocorre principalmente em Neea, sendo essa a primeira citação desse atributo para Guapira. Os espécimes examinados de Blanchet 3972 a, Blanchet $3972 b$, sintipos de $P$. venosa apresentam apenas inflorescência terminal, e sem caulifloria e em nada diferia nos demais caracteres, de plantas com caulifloria incluídas na mesma espécie. O lectótipo selecionado foi o espécime de $\mathrm{P}$ por apresentar flores pistiladas em cimeiras terminais trifloras, dispostas de modo racemoso ao longo do ramo distal da inflorescência, enquanto os outros sintipos em BR e $\mathrm{K}$ possuem inflorescências estaminadas jovens. Uma característica que ajuda na identificação da espécie, por ser raro nas outras espécies de Guapira, e que pode ser facilmente observável nos espécimes em herbário, é a presença de nervuras muito salientes na face inferior da folha, caráter que empresta o nome à espécie.

Esta é a espécie do gênero que mais se assemelha a algumas espécies de Neea, pela caulifloria e pelas flores dispostas racemosamente nos ramos distais da inflorescência. Entretanto, as espécies de Neea apresentam flores isoladas, enquanto $G$. venosa apresenta tríades (cimeiras trifloras), além das outras diferenças no nível genérico.

Distribuição geográfica e habitats (Fig. 30): G. venosa tem distribuição ampla, ocorrendo desde a Venezuela, passando pela Amazônia, e de forma disjunta atingindo o litoral da Bahia e Espírito Santo. Esse padrão é bastante similar ao que ocorre em várias espécies de Neea. G. venosa ocorre principalmente em florestas úmidas especialmente nas matas de terra firme da Amazônia e nas restingas litorâneas. Algumas exsicatas trazem a informação de que as árvores desta espécie são frequentadas por formigas agressivas.

Material examinado: Brasil. Acre: Rio Branco, S.R. Lowrie et al. 506, 13.X.1980, fr. (MG). Amapá: Macapá, S.A. Mori e J. Cardoso 17650, 3.I.1985, bot. est. (MG). Amazonas: Camanaus, G.T. Prance et al. 15887, 31.X.1971, fl. est. (K, MG); Maraã, 01 ${ }^{\circ} 50^{\prime}$ S 6535W, C.A. Cid 3359, 28.X.1982, fl. pist. (MG, R). Bahia: Valença, A.M. Carvalho e T. Plowmann 1508, 7.II.1983, fl. pist. (CEPEC, SPF). Espírito Santo: Marilândia, J.R. Pirani et al. 3393, 5.XII.1994, bot. (NY, SPF); São Mateus, R.F. Monteiro et al. 270, 10.I.2008, fl. pist. (RB, SPF). Maranhão: km 370 da Rodovia Belém-Brasília, E. Oliveira 1094, 30.VIII.1960, fl. est. (UB); Santa Luzia, M.F.F. Silva et al. 1013, 5.IV.1983, bot. est. (HRB, MG). 

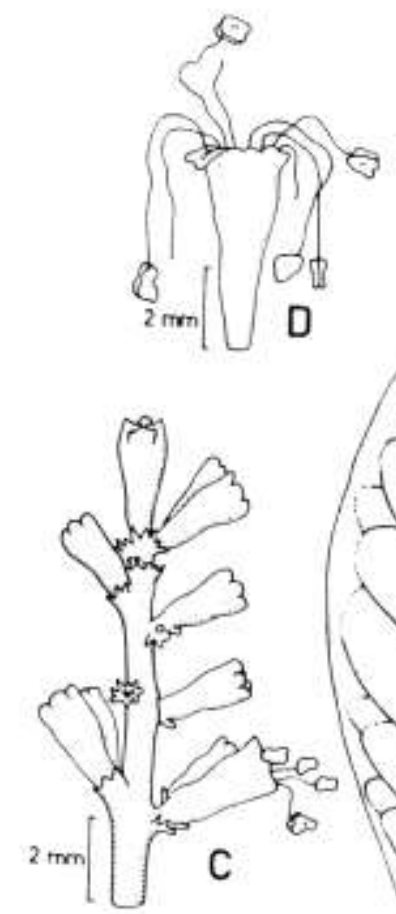

(1)
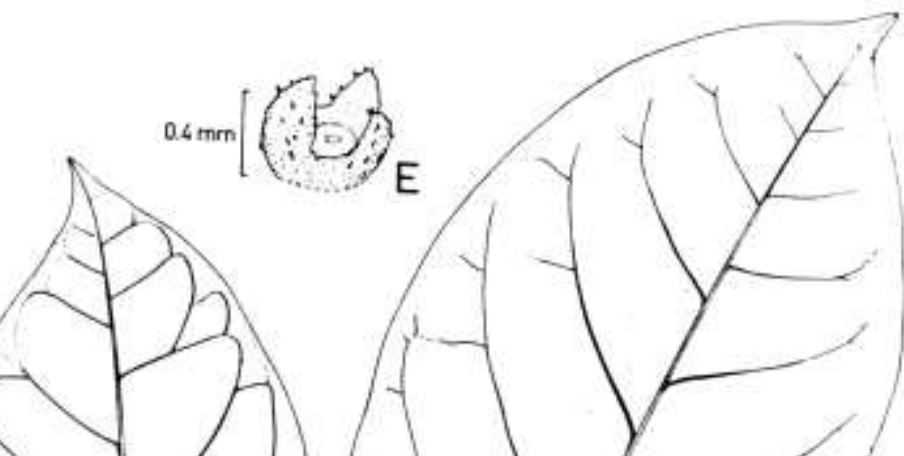


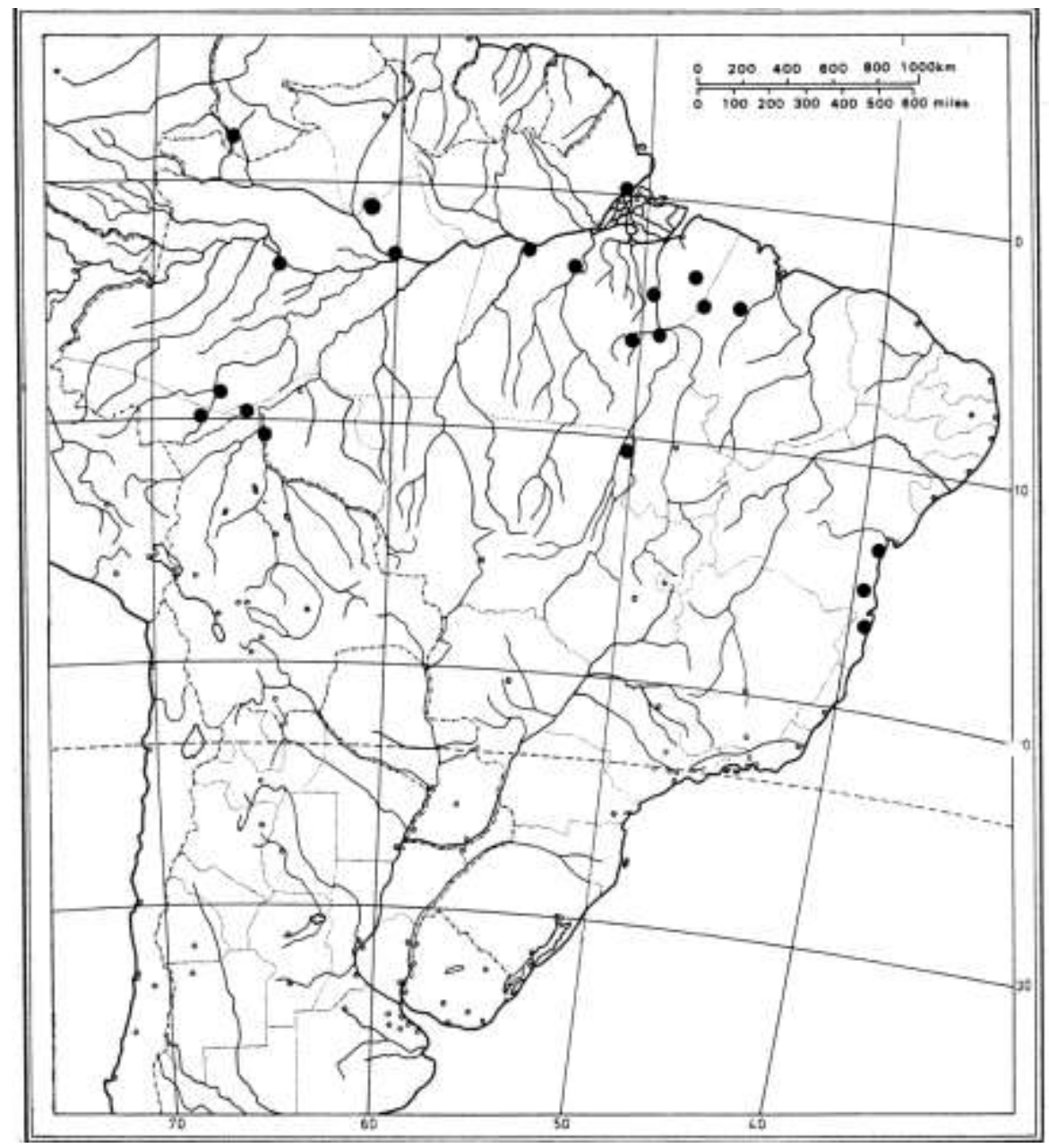

Fig. 30 - Distribuição geográfica de Guapira vernosa.

Pará: Altamira/ltaituba, C.C. Berg et al. BG-758, 30.X.1977, fl. est. (K, MG, RB, UEC); Paragominas, G.T. Prance \& N.T. Silva 58695, 13.VIII.1964, fl. est. (K, MG, UB); Tucuruí, A.S. Silva et al. 178, 25.X.1977, infl. jovem (IPA, K). Rondônia: Guajará-Mirim, G.T. Prance et al. 6688, 2.VIII.1968, bot. est. (K, MG). Tocantins: Ilha do Bananal, J.R. Pirani et al. 1223, 11.X.1985, bot. pist. (INPA, NY, SPF).

2. NEEA Ruiz \& Pav., Fl. peruv. prodr.: 52. 1794. Espécie-tipo: Neea verticillata Ruiz \& Pav. (lectotipificação de Standley 1918).

Neaea Juss., Ann. Mus. Hist. nat. 2: 275. 1803. ortho.var. Neeania Raf., Princ. fond. somiol.: 30. 1814.

Mitscherlichia Kunth, Vier bot. Abh.: 209. 1832.

Neeaea Poepp. \& Endl., Nov. gen. sp. pl. 2: 45. 1838. ortho.var. Nebra Nor. ex Choisy in DC., Prodr. 13(2): 447.1840.

Eggersia Hook.f. in Hook. Ic. P1. 15: 1401. 1883.

Árvores, arvoretas a arbustos, lenhosos, inermes, eretos, em geral ramificados dicotômicamente a cada 2 nós. Folhas opostas a subopostas, raro alternas em ramos muito alongados, geralmente 3-4 verticiladas nas ramificações e nos ápices dos ramos, pares quase sempre desiguais, especialmente os inferiores, coriáceas a membranáceas, pecioladas ou sésseis. Inflorescências em cimeiras terminais usualmente longo-pedunculadas, frequentemente nas bifurcações, aglomeradas ou comumente laxas, raramente caulifloras; ramos da inflorescência opostos, alternos ou verticilados, na frutificação espessados, patentes, pouco ou não alongados. Bráctea 1 na base dos ramos ou ausente, bractéolas em geral 3, raramente 2, na base da flor ou do antocarpo, não espaçando-se na frutificação, deltoides a filiformes setáceas, raramente maiores que as flores, persistentes ou raramente decíduas. Flores diclinas (unissexuadas), normalmente com rudimentos do sexo abortado, pequenas, sésseis, (4)5(6)-meras, sépalas unidas; botões florais de ápice agudo a arredondado, induplicado-valvar, induplicações não salientes. Flores estaminadas em geral urceoladas, contraídas no ápice, raramente tubulosas ou campanuladas abertas, perianto membranáceo-carnoso, lobos eretos ou reflexos; estames 5-13, frequentemente 8 , desiguais, e 
em geral 4 maiores alternados com 4 menores, normalmente inclusos, raramente apenas visíveis nas flores campanuladas, filetes unidos na base, tecas quase sempre muito desiguais; pistilódio normalmente presente, estigma não desenvolvido, incluso, menor que os estames. Flores pistiladas cilíndricourceoladas, contraídas na região mediana e no ápice, perianto espessado internamente desde a base até a região mediana logo acima do ovário, lobos denteados eretos ou reflexos; estaminódios 5-8, sempre presentes, muito alongados na frutificação; rudimentos de anteras compressos, em geral inclusos na cúpula do antocarpo na frutificação; glândulas intraestaminais raramente presentes, minúsculas; ovário séssil, globoso, alongado, estilete cilíndrico; estigma assovelado agudo ou dilatado alongado, papiloso ou pouco fimbriado unilateralmente, às vezes lacerado, pouco ou nada saliente do perianto. Antocarpos carnosos, globosos ou elipsoides, róseos a vináceoescuros, brilhantes, contraídos pouco abaixo do ápice e mais contraídos no ápice formando uma cúpula apical sobre o antocarpo, lobos do perianto frequentemente contraídos, eretos ou fechados. Fruto aquênio membranáceo, testa da semente aderida ao fruto; embrião reto, cotilédones desiguais, radícula curva ou reta, perisperma normalmente gelatinoso.

gênero foi dedicado ao botânico francês Luiz Née, coletor do final do século XVIII no México e América do Sul.

A extensa descrição do gênero monotípico Mitscherhchia feita por Kunth (1832), com flores urceoladas e 6 estames desiguais inclusos, confere plenamente com Neea e permite a sinonimização já proposta por Heimerl (1934). Porém, M. spectabilis, sem descrição e sem dados de procedência ("patria ignota"), não pode ser identificada com segurança como qualquer espécie de Neea, embora provavelmente possa tratar-se de $N$. verticillata, devido a caracterização das folhas com forma oblonga e de enorme dimensão.

Até o final do século passado, Neea nem sempre era bem aceito porque suas diferenças em relação ao gênero próximo Pisonia L. "sensu lato" eram tênues: Neea era definido pelos estames inclusos e antocarpos carnosos e Pisonia pelos estames exsertos e frutos secos ou carnosos. A segregação de Guapira Aubl., com frutos carnosos, de Pisonia "sensu strictu", com frutos secos glandulosos, viabilizou a aceitação de Neea, e contribuiu para tornar os três gêneros mais bem caracterizados, pois Guapira e Neea são muito mais semelhantes entre si do que com Pisonia. Apesar dessa constatação, mesmo recentemente ainda há discordâncias: Burger (1983) comenta que "Neea pode não ser suficientemente distinto de Guapira para merecer categoria de gênero" e Dumas (1990), que em curta comunicação sobre as espécie cubanas aponta que não se sustenta a manutenção dos dois gêneros. Contudo no presente estudo considermaos que apesar das diferenças vegetativas entre ambos gêneros serem realmente muito pequenas, as distinções reprodutivas são constantes e evidentes.

As espécies de Neea apresentam quase sempre os ramos distais da inflorescência alongados, mais ou menos racemiformes, com flores isoladas, aglomeradas ou laxas, botões de ápice agudo ou arredondado, geralmente curto-acuminado, sem induplicações salientes lembrando uma prefloração valvar, as flores estaminadas são geralmente urceoladas com estames inclusos, as flores pistiladas apresentam estigma agudo, papilhoso, pouco franjado ou lacerado unilateralmente ou até pouco penicelado irregularmente, além de ser pouco ou não exserto do perianto, e os antocarpos apresentam duas pequenas constrições, sendo uma abaixo do ápice e outra no próprio ápice, formando uma câmara em cúpula apical, a qual frequentemente encerra o estigma e os rudimentos de antera. As espécies de Guapira, por sua vez, apresentam os ramos distais da inflorescência em cimeiras trifloras, raramente estas cimeiras são dispostas de modo recemiforme (exceto em G. venosa), botões de ápice truncadoclavado, 5-radiado com induplicações salientes, prefloração induplicado-valvar, as flores estaminadas são campanuladas com estames exsertos, as flores pistiladas apresentam estigma penicelado radiadamente e bem exserto do perianto, e os antocarpos apresentam apenas uma constrição no ápice não formando cúpula apical e os estaminódios são pouco ou não desenvolvidos.

Uma das características marcantes de Neea são os estaminódios bem desenvolvidos na frutificação, e tal situação ocorre devido ao alongamento dos estaminódios que acompanham o desenvolvimento do fruto dentro do antocarpo. Tal característica é de fácil observação pela presença dos rudimentos de antera inclusos na câmara apical, em geral aderidos ao estilete persistente no fruto. Entretanto, na dissecção dos antocarpos, frequentemente ocorre o rompimento dos filetes que são delgados e delicados. Pelo fato dos rudimentos de antera estarem comprimidos pelo espessamento interno da flor pistilada, parece à primeira vista que os delgados filetes foram rompidos pelo alongamento do fruto, mas um exame detalhado da parede do fruto ou da parede do antocarpo mostra que os filetes estão sempre aderidos em uma destas paredes. Frequentemente em Neea os rudimentos de antera estão acima do espessamento interno da flor pistilada.

A frequente ocorrência de tecas muito desiguais em Neea explica-se pelo rápido desenvolvimento das anteras apertadamente dentro dos botões, pois nota-se que em geral as anteras já estão abertas dentro do botão antes da antese. Ocasionalmente ocorre em espécies de Neea carpelos não muito bem soldados, e muitas vezes nas flores estaminadas podem ocorrer pistilódios com o carpelo semiaberto, ou com a sutura bem visível bastando uma ligeira compressão para que ele se abra. Além disso, as flores pistiladas de Neea, diferentemente das de Guapira, em geral são encontradas com a parte distal do perianto muito 
predadas, e talvez pela mesma razão muitos antocarpos apresentam-se sem a cúpula apical e com vestígios de predação.

Pelo exposto, em relação aos dois gêneros, considera-se que a unificação de Guapira e Neea, posicionando as espécies dos dois grupos em seções diferentes, seria apenas um artifício de classificação, com grande complicação nomenclatural e só deveria ser realizado com base em estudos filogenéticos detalhados, especialmente com base em dados moleculares e com grande número de espécies.

No Catálogo de Plantas do Brasil, Sá (2010) listou 21 espécies de Neea, das quais 14 são referidas neste trabalho, sendo que apenas $N$. uleana está referida somente aqui. Das sete espécies restantes, Neea altissima Poepp. \& Endl., $N$. divaricata Poepp. \& Endl., N. pubescens Poepp. \& Endl., N. tristis Heimerl e $N$. virens Poepp. ex Heimerl foram aqui consideradas como Táxons Duvidosos. Neea grandis Maguire \& Steyerm. não foi incluída neste trabalho e o holótipo Brazão \& Silva 60606 não foi estudado, e $N$. robusta Steyerm. não foi incluída nesse trabalho e o parátipo Silva \& Brazão 60765 não foi estudado.

Após a conclusão deste trabalho, foi descrita a nova espécie Neea alumnorum M. Pignal, Soares Filho \& Romaniuc (Pignal et al. 2013), restrita à Mata Atlântica da Bahia, Brasil, não incluída no presente tratamento. Segundo os autores, a nova espécie seria relacionada principalmente a $N$. floribunda.

Chave para as espécies de Neea no Brasil

1. Folhas sésseis a sub-sésseis, de base cordada a arredondada.

2. Folhas membranáceas com curto pecíolo ciliado; brácteas e bractéolas em geral iguais ou mais longas que a flor estaminada

2.14. N. uleana

2'. Folhas coriáceas a cartáceas, glabras; brácteas e bractéolas em geral mais curtas que as flores estaminadas.

3. Folhas geralmente de ápice arredondado a emarginado; estigma assovelado, papiloso

2.13. N. theifera

3'. Folhas geralmente de ápice agudo, acuminado; estigma lacerado-foliáceo 2.1. N. duckei

1'. Folhas pecioladas, de base obtusa a aguda.

4. Inflorescências hirsutas; ramos terminais das inflorescências com flores em glomérulos globosos; brácteas geralmente iguais ou maiores que as flores.

5. Inflorescência pêndula, pedúnculo flexivel, longo, delgado

2. 4. N. hirsuta

5'. Inflorescência não pêndula, pedúnculo lenhoso, curto

2.11. N. parviflora

4'. Inflorescências glabras, pubérulas ou menos frequente hírtulas; ramos terminais das inflorescências com flores em geral laxas, não aglomeradas; brácteas menores que as flores.

6. Flores estaminadas curto-campanuladas, pequenas, anteras inclusas porém evidentes

2.8. N. obovata

6'. Flores estaminadas urceoladas, tubulosas ou longo-campanuladas, anteras não evidentes.

7. Inflorescências verticiladas 2.12. N. pendulina

7'. Inflorescências não verticiladas.

8. Flores estaminadas tubulosas a longo-campanuladas, ápice normalmente não constricto.

9. Folhas ovadas, ovado-lanceoladas a lanceoladas, nervuras paralelas e aproximadas; flores pubérulo-ferrugíneas

9'. Folhas oblongas, obovadas, elípticas a sub-rômbicas, nervuras distanciadas; flores glabras a pouco pubérulas.

10. Folhas geralmente não enegrecidas quando secas; pedúnculos das inflorescências longos, pêndulos, flexíveis

10'. Folhas em geral pardas a negras quando secas; pedunculos das inflorescências, curtos, não pêndulos, inflexíveis.

11. Folhas adultas predominantemente obovadas, cartáceas, nervuras salientes na face inferior; pedúnculo da inflorescência 0,8-4,3 cm compr

11'. Folhas adultas usualmente elípticas a sub-rômbicas, coriáceas, nervuras não salientes na face inferior; pedúnculos da inflorescência 0,5-2,0 cm compr.

2.9. N.oppositifolia

2.6. N. macrophylla

8'. Flores estaminadas urceoladas, ápice em geral constricto.

12. Folhas usualmente grandes, $9,0-45,0 \mathrm{~cm}$ compr., lanceoladas a oblanceoladas, glabras.

13. Inflorescências no caule ou em ramos velhos, pedúnculos espessos e rígidos

13'. Inflorescências em ramos terminais, pedúnculos delgados e flexíveis

12'. Folhas usualmente pequenas a médias, $5,0-21,0 \mathrm{~cm}$ compr., elípticas a obovadas, frequentemente pilosas.

14. Folhas em geral elípticas, indumento hírtulo amarelado, nervuras pouco salientes na face inferior

14'. Folhas em geral obovadas, indumento tomentoso ferrugíneo, nervuras bem salientes na face inferior 
2.1. Neea duckei (Huber) Furlan, comb.nov. $\equiv$ Pisonia duckei Huber, Bol. Mus. Paraense Emilio Goeldi, Bot. 5(2): 350. 1909. Tipo: Rio Mapuera, Cachoeira do Paraíso, 11.XII.1907, fl. est., A. Ducke 9095 (holótipo MG n.v.; isótipo RB!).

Fig. 31

Arbustos escandentes a árvores, até $8 \mathrm{~m}$ alt., caule ca. $6,0 \mathrm{~cm}$ diâm.; ramificação dicotômica, predominância alternada de um dos ramos, ramos distais simpodiais, alongados, lenhosos, cilíndricos a subquadrangulares, não enegrecidos quando secos; cicatrizes opostas e verticiladas;entrenós 2,5-12,5 cm compr.; gemas ferrugíneas. Folhas com pecíolo até 6,5 $\mathrm{mm}$ compr., até $2,0 \mathrm{~mm}$ espessura, fortemente canaliculado em cima, glabro. Laminas 6,5-22,0 x 2,5$9,5 \mathrm{~cm}$, em geral subsésseis, amplexicaules, usualmente opostas, pares pouco heterofilos, ovadas, ovado-elípticas, ovado-lanceoladas, oblongas, às vezes ligeiramente ovadas, base cordada a arredondada, ápice agudo a arredondado, glabras, margens ligeiramente recurvadas; quando secas cartáceas a frequentemente coriáceas, brilhantes, reticuladas, verde-oliva a marrom-alaranjadas, mais claras na face inferior; nervuras divergindo em ângulo quase reto, subparalelas, salientes, especialmente na face inferior. Inflorescências 7,5-13,5 x 3,0-15,0 cm, axilares e terminais, glabras; pedúnculo $3,0-15,0 \mathrm{~cm}$ compr; ramos primários irregularmente dicotômicos a alternos, patentes a retronásticos, às vezes verticilados em inflorescências jovens; brácteas ausentes; bractéolas 0,5-1,0 mm compr., lineares a oblongas, pouco pilosas; botões estaminados 1,5-3,0 x 0,5-1,5 mm; flores estaminadas 4,0-6,0 × 2,0-3,5 mm, urceoladas a obovoides, ápice constricto, viloso ferrugíneo na base, estames 7-9; flores pistiladas 4,0-5,0 x 2,0-2,4 mm; estaminódios 6-7; estigma foliáceo lacerado, incluso. Infrutescências $7,5-10,5 \times 3,5-10,5 \mathrm{~cm}$, ramos distais mais espessos que o pedúnculo; pedúnculo $4,3-5,8 \mathrm{~cm}$ compr.; antocarpos 6,0-11,0 x 4,0-6,0 mm, às vezes pedicelo pouco intumescido acima das bractéolas; cúpula 0,5-1,5 mm compr., 1,8-2,5 mm larg., deprimida, estigma às vezes pouco saliente.

O tipo de Pisonia duckei possui flores estaminadas urceoladas com estames inclusos e antocarpos com cúpula apical e portanto pertence ao gênero Neea. Heimerl (1914) já havia sugerido isso, mas não fez a nova combinação. Apesar de geralmente as flores pistiladas de Neea duckei apresentarem estigma exserto, pode ocorrer também flores com estigma incluso, porém às vezes na frutificação o estigma pode tornar-se um pouco saliente devido ao murchamento da cúpula membranácea sobre 0 antocarpo.

Vegetativamente Neea duckei é semelhante a $N$. theifera e a $N$. uleana. Diferenciam-se porque $N$. duckei não possuir brácteas na base dos ramos da inflorescência, as folhas são geralmente coriáceas com pecíolos curtos e glabros e não possuem cera na superfície e não enegrece quando seca. Diferentemente, $N$. theifera apresenta brácteas curtas e espessas na base de todos os ramos da inflorescência e as folhas possuem cera na superfície que quase sempre enegrece quando seca, e $N$. uleana apresenta brácteas foliáceas longas e as folhas são membranáceas com pecíolos curtamente pilosos. Espécimes estéreis de Neea duckei também podem ser confundidos com Guapira pernambucensis, porém as folhas de $N$. duckei apresentam ápice mais agudo e nervuras muito mais evidentes e mais próximas.

Distribuição geográfica e habitats (Fig. 32): Neea duckei parece ser espécie pouco comum, nas matas úmidas onde ocorre. É conhecida de poucas coleções do Pará e Bahia, portanto com um padrão de disjunção semelhante ao de outras espécies do gênero.

Material examinado: Brasil. Bahia: Ilhéus, L.A.M. Silva et al. 1834, 27.II.1985, infl. jovem (CEPEC); Una, L.A.M. Silva et al. 1304, 20.VII.1981, infl. jovem (CEPEC, SPF). Pará: Rio Erepecuri/Trombetas, A. Ducke HAMP 15000, 20.X.1913, fl. pist./fr. (RB); Rio Tocantins, A. Ducke HAMP 15626, 4.I.1915, fl. pist./fr. (RB); Serra Paranaquara, $A$ Ducke s.n., 7.X.1919, bot. est. (RB 14148).

2.2. Neea floribunda Poepp. \& Endl., Nov. gen. sp. pl. 2: 46. 1838. Tipo: Peru "in sylvis provinciae Maynas, martio floret", Poeppig s.n. ? (holótipo, n.v.).

Neea cauliflora Heimerl in Engl. \& Prantl, Nat. Pflanzenfam. 16c: 129. 1934. Tipo: Brasil, Amazonas, Ule n.9365a, Ule n. 9365 b (síntipos n.v.).

Fig. 33

Arbustos, arvoretas a árvores, 2,0-22,0 m alt., caule 8,0-72,0 cm diâm.; ramos distais em geral muito compressos, às vezes pouco fistulosos; entrenós 2,0$13,0 \mathrm{~cm}$ compr., os terminais muito reduzidos, ca. 0,5 $\mathrm{cm}$ compr.; gemas ferrugíneas. Folhas com pecíolo 0,8-5,5 cm compr., até $5,0 \mathrm{~mm}$ espessura, glabro, lenticelado, enrugado quando seco. Laminas 9,8-44,0 x 3,9-16,0 cm, elípticas, elíptico-lanceoladas, obovadoelípticas, frequentemente oblanceoladas, raramente ovadas, os pares usualmente desiguais, glabras; base aguda, muitas vezes abruptamente obtusa a arredondada, raramente auriculada, comumente inequilátera; ápice agudo, obtuso a arredondado, curto-acuminado a caudado, cauda aguda; quando secas, cartáceas a subcoriáceas, opacas, pardacentas a verde-oliva, nervuras muito salientes na face inferior especialmente a nervura mediana. Inflorescências 9,5$17,5 \times 8,5-11,0 \mathrm{~cm}$, usualmente caulifloras, menos frequentemente em ramos terminais, rígidas, indumento pubérulo a pulverulento, mais condensado nas extremidades, ferrugíneo-escuro; pedúnculo 3,5$14,5 \mathrm{~cm}$ compr., ca. $5,0 \mathrm{~mm}$ espessura; ramos primários dicotômicos, os secundários em geral racemosos a espiciformes, frequentemente flores aglomeradas nos ramos distais; brácteas ca. $1,5 \mathrm{~mm}$ compr., na base dos ramos secundários, avermelhadas; bractéolas 0,3-0,5 x 0,3-1,0 mm larg., 


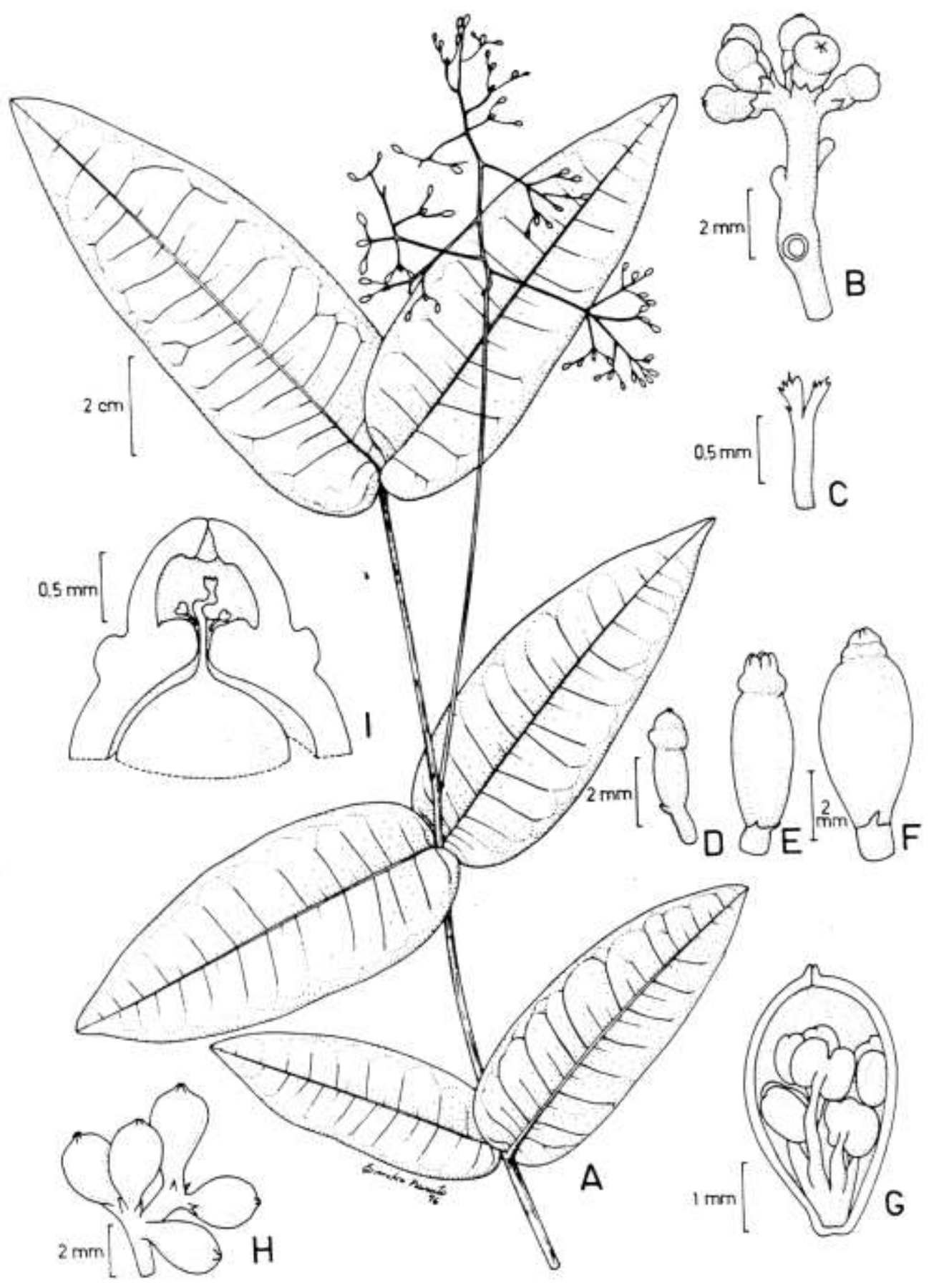

Fig. 31 - Neea duckei: A. Ramo de planta estaminada. B. Ramo terminal da inflorescência pistilada. C. Detalhe do estigma. DF. Fases de desenvolvimento do antocarpo. G. Flor estaminada, cálice em corte longitudinal. H. Ramo terminal de inflorescência estaminada. I. Esquema do ápice do antocarpo em corte longitudinal. (A-I - A. Ducke s.n. HAMP 15626). 


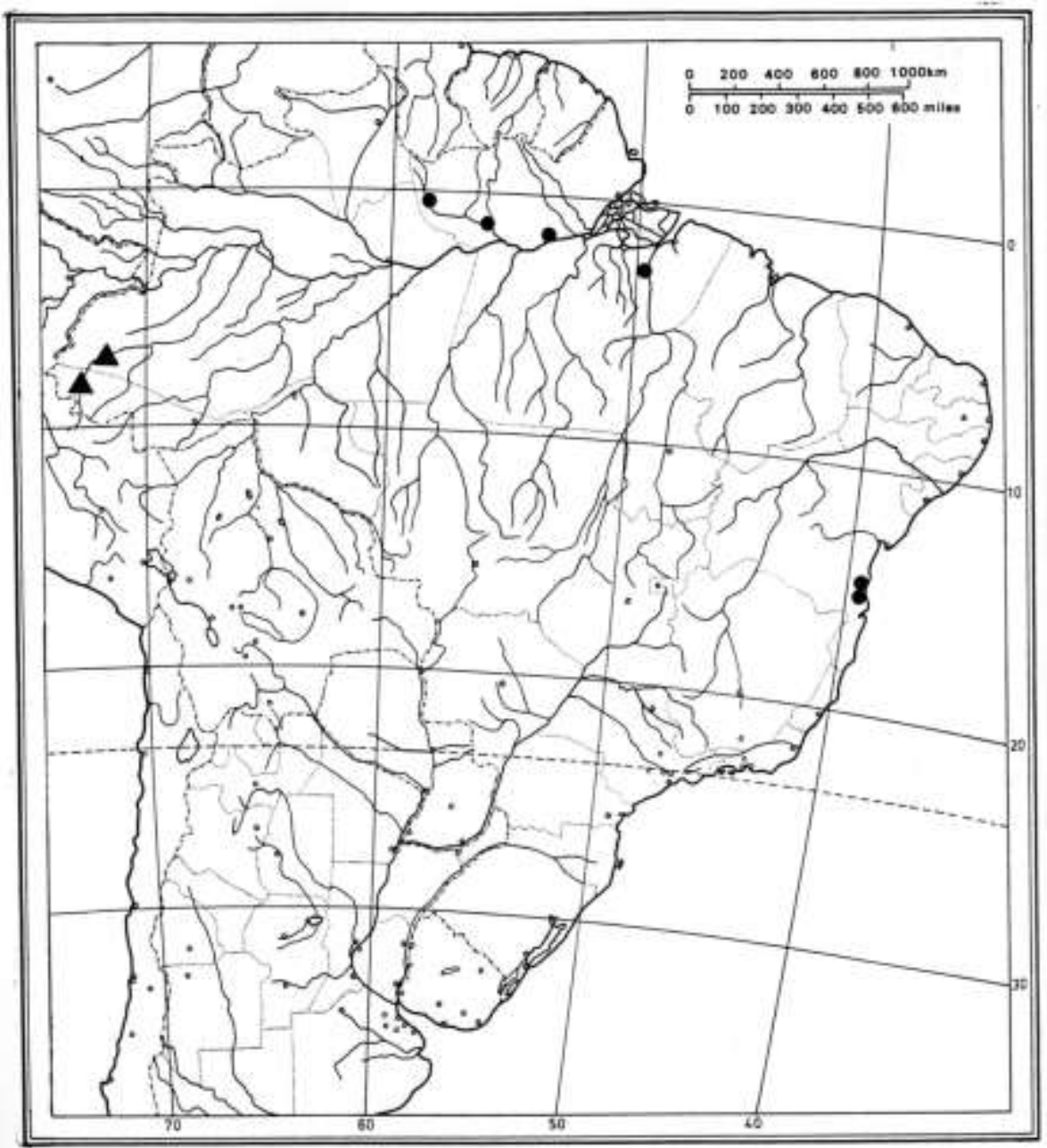

Fig. 32 - Distribuição geográfica de Neea duckei (círculos) e N. uleana (triângulos).

comumente mais largas que longas, ápice arredondado a obtuso; botões estaminados ca. 6,0 x ca. 3,0 mm larg., globosos a obovoides, não estreitados na base, ápice arredondado, pouco vilosos; flores estaminadas 7,5-8,0 x 3,0-3,5 mm, globosas a pouco alongadas, glabras ou pubérulas na base, perianto vermelho; lobos do perianto amarelados, em geral semi-abertos; estames 7-10; pistilódio às vezes não totalmente soldados; flores pistiladas $6,0-8,0 \times$ ca. $2,5 \mathrm{~mm}$, tubulosas; estaminódios 6-8; estigma agudo, saliente até 1,0 mm. Infrutescências 9,8-10,6 x 5,6-9,8 cm; pedúnculos 3,5$6,0 \mathrm{~cm}$ compr., até $4,5 \mathrm{~mm}$ espessura, ramos alternos patentes ou dicotômicos, alongados; antocarpos 10,018,0 x 5,0-11,0 mm, roxos quando maduros; cúpula apical 2,0-3,0 $\mathrm{mm}$ alt.

Ao descreverem N. floribunda. Poeppig \& Endlicher (1838) referiram apenas a localidade da coleta do espécime-tipo, sem coletor ou data. $\mathrm{Na}$ descrição da espécie são referidas apenas características vegetativas e das flores estaminadas. No herbário de Paris foi examinado um material da coleção de Poeppig, proveniente do Peru, província de Maynas, que incluía folhas e antocarpos, o qual foi anotado como tipo de $N$. floribunda. Embora pertença a esta espécie, não pode ser o holótipo que deverá ser uma planta com flores estaminadas. Spichiger \& Defferrard (1986) mencionam Poeppig 2329 como tipo de $N$. floribunda, no entanto este material é citado por Choisy (1849) como tipo de N. laxa.

A circunscrição de Neea floribunda aqui aceita, foi baseada na descrição original de Poeppig \& Endlicher (1838), nos conceitos de Standley (1937a) para as espécies peruanas de Neea, e através das comparações com os espécimes Krukoff 6808 e 8270 , identificados por Standley.

Na descrição de Neea cauliflora Heimerl (1934) a espécie apresenta inflorescências cauliforas e terminais, sendo esse o principal caráter distintivo em relação a $N$. floribunda apenas com inflorescências caulifloras. O binômio foi sinonimizado por Standley 


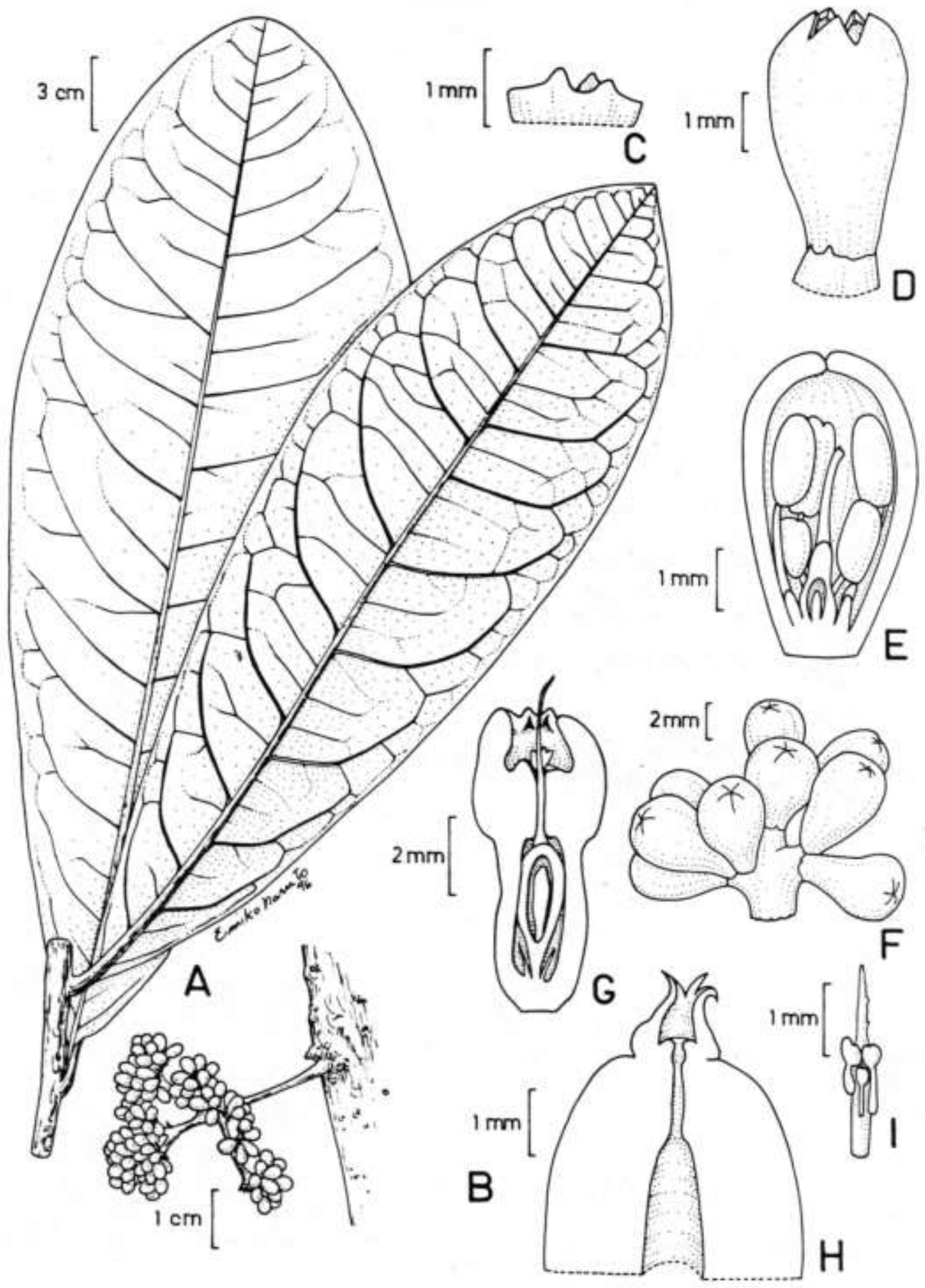

Fig. 33 - Neea floribunda: A. Ramo com folhas. B. Parte do caule com inflorescência estaminada. C. Bráctea e bractéolas. D. Flor estaminada. E. Botão estaminado em corte longitudinal. F. Ramo terminal de inflorescência estaminada. G. Flor pistilada em corte longitudinal. $\mathrm{H}$. Esquema do ápice do antocarpo em corte longitudinal. I. Estigma do fruto com partes de estaminódios aderidas. (A, C-F - L.A.M. Silva et al. 1816; B - P.J.M. Maas et al. 7010; G - L.A.M. Silva et al. 1657; H-I - M. Silva 2141). 
(1937a) e de acordo com os materiais examinados, a proposta fica confirmada.

Neea floribunda é uma espécie bem caracterizada, pois além da caulifloria apresenta folhas frequentemente oblanceoladas, em geral muito grandes, e inflorescências relativamente lenhosas, rigidas e com indumento ferrugíneo escuro.

No espécime Setz s.n. UEC 43758 consta a informação de que a polpa do antocarpo maduro é comida por macacos ("Pithecia").

Distribuição geográfica (Fig. 34): N. floribunda é uma espécie com poucas coletas disponíveis, que mostram uma distribuição disjunta, com populações na região amazônica da Guiana, Peru, Brasil e Bolívia, e na Bahia e Rio de Janeiro.
Material selecionado: Brasil. Acre: $9^{\circ} 20^{\prime} S-69^{\circ} 00^{\prime} \mathrm{W}$ B.A. Krukoff 5344, 9.VIII.1933, fl. est. (K); Cruzeiro do Sul, G.T. Prance et al. 2899, 27.X.1966, fl. est. (R). Amazonas: Fonte Boa, M. Silva 2141, 22.X.1968, fr. (MG, UB); São Paulo de Olivença, B.A. Krukoff 8270, 26.X.1936, fl. pist. (BR, BM, K, P). Bahia: Canavieiras, T.S. Santos e L.A.M. Silva 3692, 18.XI.1981, fl. est. (CEPEC, SPF); Santo Antonio de Jesus, J.R. Pirani et al. 2728, 30.I.1993, fl. est. (CEPEC, NY, SPF). Pará: Parauapebas, J.A.A. Bastos 13, 16.VI.1988, bot. est. (CVRD, HRCB). Rio de Janeiro: Angra dos Reis, D. Araujo et al. 6192, 11.IV.1984, bot. est. (GUA). Rondônia: Porto Velho, G.T. Prance et al. 8262, 7.XI.1968, fr. (R).

Bolívia. Pando: G.T. Prance et al. 6228, 20.VII.1968, fl. pist. (R)

Guiana. Rio Waini, C.W. Anderson 612, 9.XII.1910, bot. est. (K).

Peru. prov.Maynas, Poeppig s.n.,s.d., fr. (P).

Suriname. P.A. Florschultz \& P.J.M. Maas 2857, 15.Il.1965, fr. (SP).

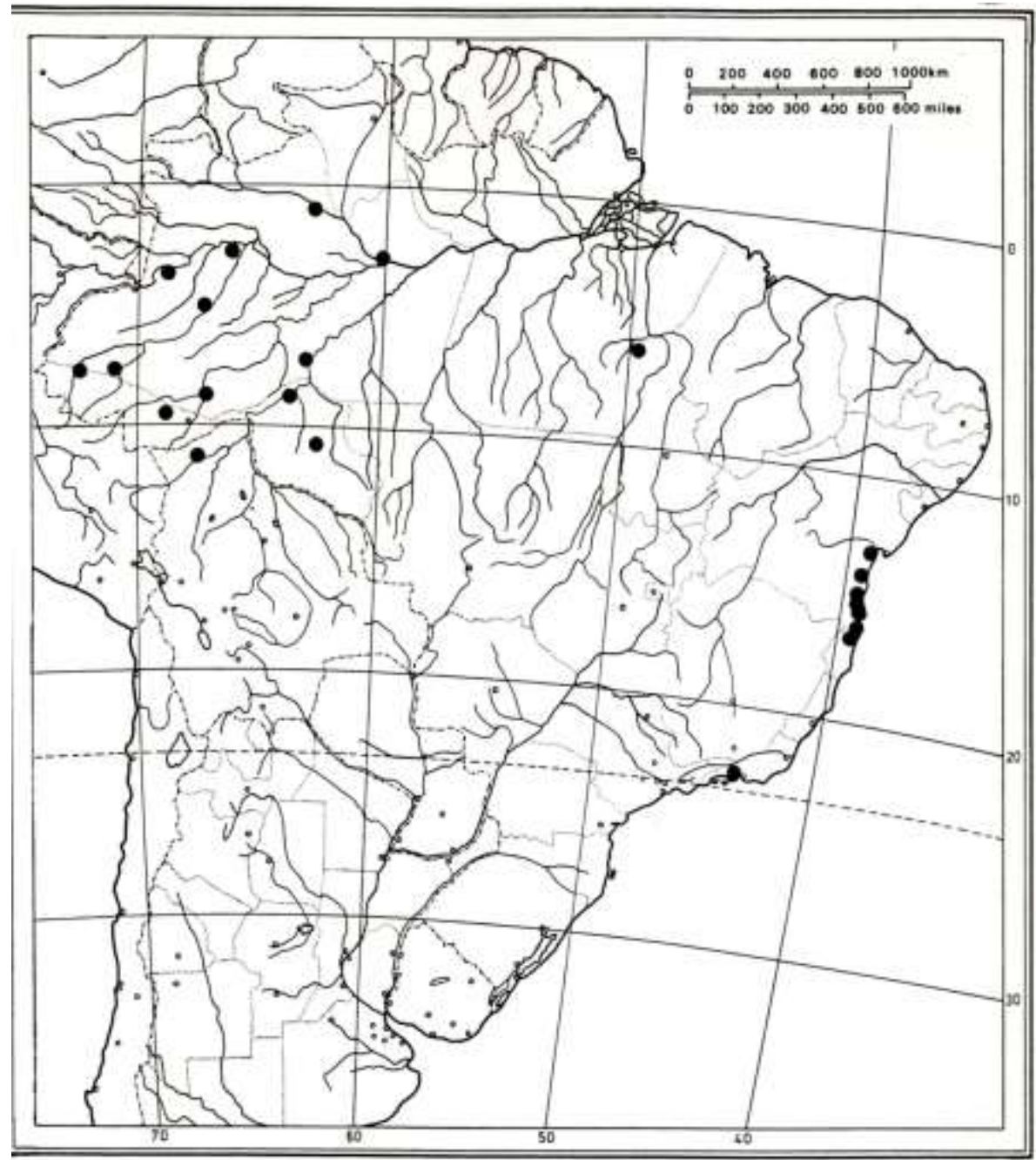

Fig. 34 - Distribuição geográfica de Neea floribunda. 
2.3. Neea hermaphrodita S.Moore, Trans. Linn. Soc. Bot. 2(4): 442. p1. 28. 1895. Tipo: "Iter Matogrossense ad Santa Cruz", X.1891/92, S. Moore 481 (holótipo BM!; isótipos K!, P!).

Neea subpubescens Heimerl, Jber. StOberrealsch., Wien 23: 36. 1897. Tipo: Brasil, "ad ripas flum. Amazonum inter Santarem et Barra do Rio Negro", $R$. Spruce s.n. (holótipo, W n.v.; isótipos, P!, K!, RB!). Syn. nov.

Neea selloiana Heimerl, Jber. StOberrealsch., Wien 23: 38. 1897. Tipo: Peru, "Peruvia orientalis prope Tarapoto", R. Spruce 4196 (lectótipo K!, isolectótipo BR!, P!, foto R! aqui designados). Syn. nov.

Neea bangii Rusby, Bull. New York Bot. Gard. 4: 435. 1907. Tipo: Bolívia, "at the foot of Mount Uchimachi", 17.VII.1894, Bang 2346 (holótipo F n.v.; isótipos K!, M!). Syn. nov.

Fig. 35.

Nomes vulgares: juá-mole (Ratter 3959), joão-mole (Ratter 4474).

Arbustos a arvoretas, 1,0-6,0 m alt.; ramos dicotômicos, frequentemente alongados, glabrescentes, cinza-avermelhados quando secos; ramos novos tomentosos a hírtulos, entrenós até 10,5 cm compr., gemas ca. 1,5 mm larg., castanho-claras; tricomas ramificados, amarelados a ligeiramente ferrugíneos. Folhas com pecíolo 0,3-1,7 cm compr., cm compr., canaliculado, pubérulo a hírtulo. Laminas $5,1-16,0 \times 1,8-6,0 \mathrm{~cm}$, opostas, raramente subopostas, verticiladas nas ramificações, pares bem desiguais, as maiores elípticas, elíptico-lanceoladas, às vezes ligeiramente elíptico-obovadas, raramente pouco oblíquas, base aguda, ápice agudo, obtuso a arredondado, curto-acuminado, acúmen obtuso, as menores obovadas, ápice arredondado a emarginado; quando secas cartáceas a membranáceas firmes, margem em geral pouco revoluta, não muito enegrecidas, frequentemente discolores; face superior mais escura, pouco lustrosa, pouco pilosa especialmente na nervura mediana a glabra, nervuras pouco salientes; face inferior mais clara, tomentosa ou hírtula a glabrescente, tricomas mais condensados nas nervuras; nervuras secundárias $6-12$, pouco salientes, distanciadas, às vezes reticuladas. Inflorescências 4,0-9,0 x 4,2-17,0 cm, geralmente terminais no ramo do ano que continua a crescer lateralmente, às vezes pseudo-caulifloras em ramos curtos; pedúnculo 1,3-6,8 cm compr., delgado, hírtulo a glabrescente, não alongado na frutificação; ramos primários da inflorescência alternos ou comumente dicotômicos, alongados, usualmente hírtulos; ramos distais frequentemente em monocásios helicoidais racemosos, quase sempre hírtulos, pouco alongados na frutificação; brácteas 0,5-2,0 x ca. 0,7 mm, na base dos ramos finais, raramente na base dos ramos primários; bractéolas $0,5-1,5 \times$ ca. $05, \mathrm{~mm}$, na base das flores, deltoides a lanceoladas, pubéruloamareladas. Flores verde-claras a amareladas, botões de ápice agudo, base pubérulo-amarelada a pouco ferrugínea. Flores estaminadas 5,0-8,0 x 1,5-3,0 mm, elipsóide-urceoladas, perianto carnoso-membranáceo, verde-amarelado, pubérulo especialmente na base, lobos do perianto denteados, reflexos na antese; estames 6-8, filetes cilíndricos às vezes dilatados na base; pistilódio presente, estigma rudimentar obtuso, pouco lacerado no ápice. Flores pistiladas 3,0-5,0 x 1,0-2,0 mm, cilíndricas, contraídas no meio e no ápice, perianto carnoso, glabro a pouco pubérulo ferrugíneo na base; estaminódios às vezes com pólen; disco intraestaminal presente, crenulado, escuro; estilete cilíndrico; estigma agudo ou obtuso, mais espesso que o estilete, pouco lacerado no ápice, não saliente ou saliente e recurvado por $0,5 \mathrm{~mm}$ compr. Infrutescências 4,5-8,5 x 5,0-14,0 cm, ramos vináceos, espessados, brilhantes, em geral glabros; antocarpo 7,0-11,5 x 4,0-6,0 mm, globoso ou elipsóide, glabro, brilhante, roxo-escuro; cúpula apical compressa, lobos reflexos. Embrião reto, radícula curva, cotilédones carnosos, perisperma gelatinoso.

O protólogo de $N$. hermaphrodita inclui descrição clara e excelente ilustração, e o exame dos materiais-tipo e de espécimes identificados por Heimerl (Hassler 7853, Rojas 10684) e por Standley (Hoehne 5718, 5722) permitem uma segura circunscrição desta espécie.

Neea subpubescens Heimerl foi sinonimizada por apresentar as folhas e inflorescências idênticas às de N. hermaphrodita. No isótipo do herbário de Paris a etiqueta concorda exatamente com a citação de Heimerl (1897), enquanto o de Kew, embora idêntico ao de Paris, está numerado como Spruce 1103 e tem a procedência "Paraná-miri dos Ramos", que fica exatamente na região intermediária entre Santarém e Barra do Rio Negro. O espécime foi considerado como isótipo, principalmente pela anotação manuscrita de Spruce. No espécime depositado no RB consta apenas o local citado por Heimerl (1897).

Neea selloiana foi descrita por Heimerl (1897), baseada nos síntipos Sellow 769 e Sellow 1190 ambos referidos como depositados no herbário de Berlim e não localizado e Spruce 4196 citado como estéril. Apesar de haver sido examinado apenas o síntipo Spruce 4196, que apresenta flores pistiladas nas três exsicatas examinadas, nos herbários $\mathrm{BR}, \mathrm{K}$ e $\mathrm{P}$ e esse mesmo número ser citado também em $N$. parviflora Poepp.\& Endl., espécie bem diferente de $N$. hermafrodita, escolhemos como lectótipo o espécime bem completo depositado em $\mathrm{K}$ e que concorda com a descrição. Nesse mesmo trabalho, Heimerl (1897) considerou Pisonia pubescens (Poepp. \& Endl.) Schmidt como sinônimo de $N$. selloiana, apesar de ser um nome anterior. Na Flora Brasiliensis, Schmidt (1872) se referiu a Neea pubescens Poepp. \& Endl. e citou como material examinado o espécime coletado por Poeppig no Peru e que não foi mais localizado. A descrição da espécie apresentada por Poeppig \& Endlicher (1838) concorda em vários caracteres com Neea hermafrodita, contudo discorda quando os autores de $N$. pubescens referem que a mesma seria diferenciada pela inflorescência divaricada e pela pubescência muito curta, mas densa e mole na face inferior da folha. Como não temos certeza que $N$. hermafrodita e $N$. pubescens podem ser coespecífica, 


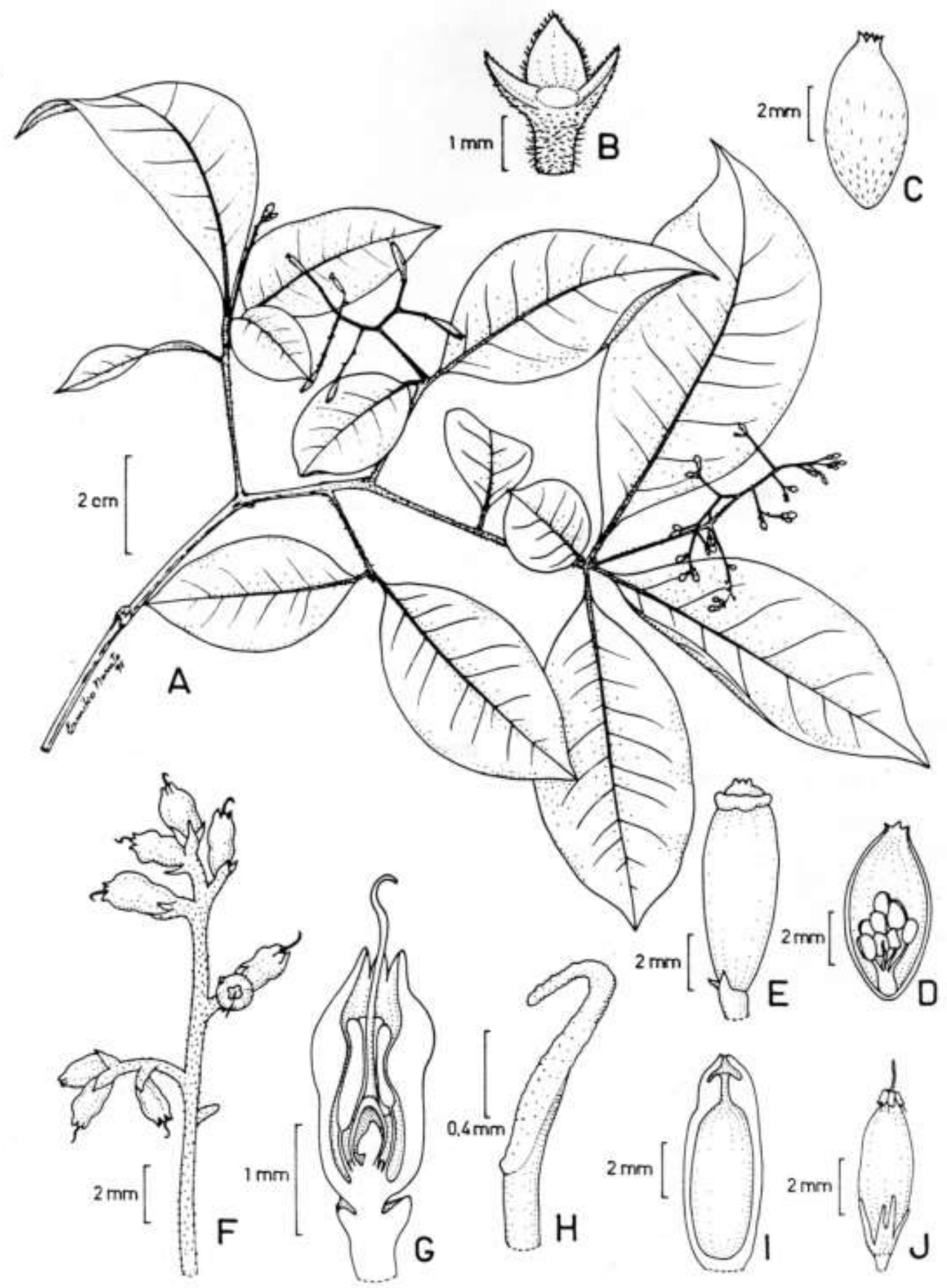

Fig. 35. Neea hermaphrodita: A. Ramo de planta feminina com inflorescências e infrutescências. B. Bráctea e bractéolas. C. Flor estaminada. D. For estaminada com o cálice em corte longitudinal. E. Antocarpo jovem. F. Ramo terminal de inflorescência pistilada. G. Flor pistilada em corte longitudinal, com glândulas na base do ovário. H. Detalhe do estigma. I. Antocarpo jovem, sem o fruto, em corte longitudinal. J. Fruto jovem e estaminódios. (A, E, I-J - C.A.C. Ferreira et al. 6418; B-D - W. Mantovani 1079; F-H - W. Thomas et al. 4251). 
preferimos considerar a última espécie como duvidosa (v.o capítulo de Espécies Duvidosas).

Neea bangii foi descrita por Rusby (1907) e aceita por Standley (1931), que a diferencia, na chave para as espécies do noroeste da América do Sul, pelas folhas de ápice arredondado, curto-acuminado, permanentemente tomentosas ou pilosas na face inferior. As folhas do material-tipo mostram o ápice obtuso a pouco arredondado, pilosidade hírtula, e inflorescência com ramos dicotômicos, características semelhantes às encontradas em $N$. hermaphrodita.

A espécie mais próxima de $N$. hermaphrodita parece ser $N$. ovalifolia. Esta última diferencia-se pelas folhas em geral ovadas, glabras e principalmente nervuras quase retas e paralelas, muito aproximadas entre si. Além disso, frequentemente apresenta inflorescências ferrugíneas e flores estaminadas cilíndricas e não urceoladas.

Distribuição geográfica e habitats (Fig. 36): $N$. hermaphrodita ocorre preferentemente em locais úmidos, como matas de galeria, borda de lagoas, canais alagáveis e floresta-de-várzea, embora haja registros também para áreas de cerrado e cerradão. A maior parte dos registros da espécie é para o estado do Mato Grosso. Foi encontrada com flores de maio a dezembro e com frutos de outubro a dezembro.

Material selecionado: Brasil. Acre: Rio Branco, S.R Lowrie et al. 240, 28.IX.1980, infl. jovem (MG); Sena Madureira, B. Nelson 593, 5.X.1980, infl. jovem, (MG, R, RB). Amazonas: Boca do Acre, G.T. Prance et al. 2305, 15.IX.1966, infl. jovem, (R). Distrito Federal: Brasília, B.A.S. Pereira et al. 2574, 21.IX.1993, fr. (HRCB). Goiás: Campos Belos, A.P. Duarte 9493, 24.X.1965, fl. pist. (RB). Maranhão: São Mateus, D.C. Daly et al. 299, 27.IX.1980, fl. pist. (HRB). Minas Gerais: Conceição das Alagoas, G. Pedralli \& J.R. Stehmann s.n., 5.X.1988, fl. pist. (HXBH 5611). Mato Grosso do Sul: Campo Grande, I.A. Rodrigues et al. 306, 9.XI.1977, fl. est. (RB). Mato Grosso: Alta Floresta, W. Thomas et al. 4090, 29.IX.1985, fl. pist. (MG, NY); Poconé, M. Schessl 268/1-7, 24.III.1993, infl. jovem (HRCB). Pará: Tucuruí, D.C. Daly et al. 1295, 8.XI.1981, fl. est. (HRB).

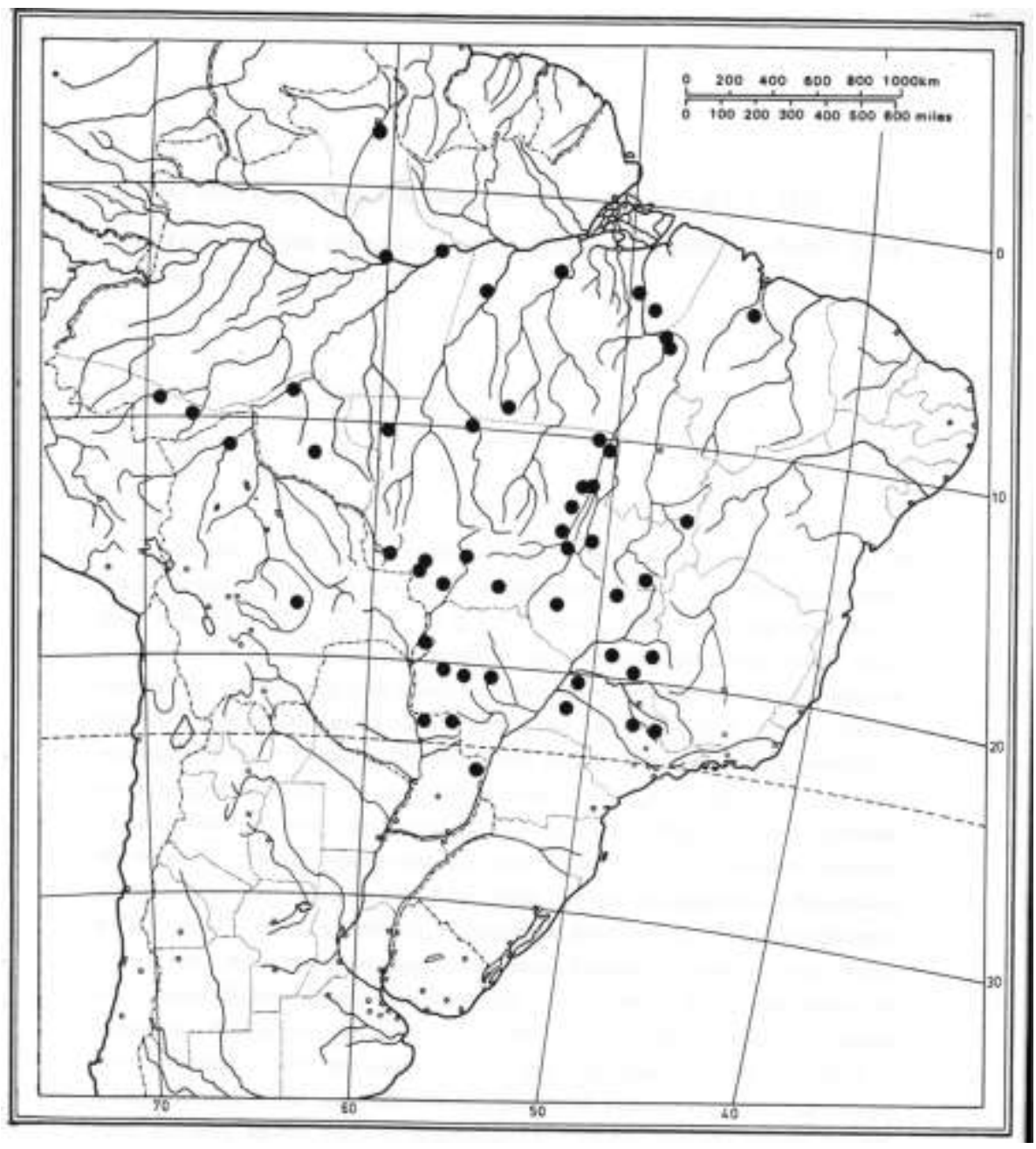

Fig. 36 - Distribuição geográfica de Neea hermaphrodita. 
Rondônia: Alvorada d'Oeste, L.C.B. Lobato et al. 312 , 31.X.1986, fl. pist. (MG). Roraima: Brás de Aguiar, M. Silva 223, 23.III.1964, fl. pist. (HB). São Paulo: Jales, W. Hoehne s.n., 26.X.1951, fl. est. (SPF 13931, HRCB). Tocantins: Ilha do Bananal, J.A. Ratter et al. 4405, 13.IX.1980, fl. est. (K, UB, UEC). pist. (UB)

Bolívia. Dep. Beni, S.G. Beck 5191, 18.X.1980, fl. est. (MO, SPF).

2.4. Neea hirsuta Poepp. \& Endl., Nov. gen. sp. pl. 2: 45. tab.161. 1838. Tipo: Peru, "in sylvis primaevis provinciae Maynas ad Yurimaguas. Martio floret", Poeppig s.n. (holótipo n.v.).

Fig. 37

Arbusto 1,0-3,0 m alt., indumento hirsuto avermelhado; entrenós 1,5-7,0 cm compr. Folhas com pecíolo 1,1$1,7 \times$ ca. $3,0 \mathrm{~mm}$, rígido, os novos muito hirsutos. Laminas $21,0-27,5 \times 7,2-11,5 \mathrm{~cm}$, ovadas, ovadoelípticas a ovado-lanceoladas, base arredondada, ápice agudo, as inferiores subopostas; quando secas, enegrecidas, face superior com superfície ligeiramente bulada, pouco áspera, nervuras impressas; face inferior hirsuta a hirsuto-tomentosa, nervura mediana espessa, nervuras primárias salientes; tricomas até 2,0 mm compr., pluricelulares, unisseriados, castanhos a pouco enegrecidos quando secos. Inflorescências $7,2-15,0 \times 2,2-4,5 \mathrm{~cm}$, axilares, pêndulas, creme; pedúnculo 4,2-15,0 cm compr., delgado, hirsutoavermelhado; ramos dicotômicos, cimeiras terminais aglomeradas nos ápices dos ramos, glomérulos ca. $8,0 \mathrm{~mm}$ diam.; brácteas até $1,5 \mathrm{~cm}$ compr., na base dos gomérulos e das címulas, lineares, maiores que os glomérulos, as maiores de ápice espessado, hirsutas; bractéolas 1,5-5,5 x ca. 0,5. mm, lanceoladas a lineares, desiguais, as laterais menores e menos pilosas; botões estaminados ca. $1,5 \mathrm{~cm}$ compr.; flores estaminadas não examinadas; menores e menos pilosas; botões estaminados ca. 1,5 cm compr.; flores estaminadas não examinadas; botões pistilados ca. $3,0 \times 1,0 \mathrm{~mm}$, ovados, ápice agudo; flores pistiladas 4,0-6,5 $x$ ca. $2,0 \mathrm{~mm}$, tubulosas, não estreitadas no ápice, indumento viloso, especialmente na região basal, perianto vermelho; lobos do perianto deltóides, agudos, patentes; estaminódios 6-7; estigma lacerado, incluso. Infrutescências pêndulas, ca. 18,0 x 5,0 cm; pedúnculo ca. $15,0 \mathrm{~cm}$ compr.; antocarpos roxos, ca. 11,0 x 6,0 mm larg.; cúpula fechada, ca. 1,5 mm alt.

Neea hirsuta é bem caracterizada pela inflorescência pêndula, densamente hirsuta, com ramos alternos, flores aglomeradas nos ápices dos ramos da inflorescência, bractéolas lineares, hirsutas e maiores que a flor estaminada, caráter mostrado na excelente ilustração de Poeppig \& Endlicher (1838). Porém, o protólogo menciona pedúnculo da inflorescência medindo até $45 \mathrm{~cm}$ de compriment, enquanto nos materiais brasileiros este atinge apenas $15 \mathrm{~cm}$.

Neea hirsuta lembra $N$. parviflora pelo tipo de indumento, pelas flores aglomeradas nos ápices dos ramos da inflorescência e pelas brácteas hírtulas maiores que as flores. Porém, em N. hirsuta o pedúnculo é muito longo e flexível, e a primeira bráctea do glomérulo dos ramos terminais é mais longa que as demais brácteas, atingindo até $1,5 \mathrm{~cm}$ de comprimento, ao passo que em $N$. parviflora 0 pedúnculo é bem curto, raramente alcançando $4,0 \mathrm{~cm}$, relativamente lenhoso, inflexível, e as brácteas dos glomérulos terminais são semelhantes entre si

Distribuição geográfica e habitats (Fig. 38): Até o momento $N$. hirsuta só foi coletada no Brasil no Amazonas, perto do Acre e disjuntamente na Bahia (Fig. 48). Dos trabalhos que contêm referências as espécies de Neea do Peru, apenas o de Liesner (1993) menciona uma coleta recente desta espécie no país. Parece ser uma espécie muito rara, com uma disjunção na maior parte da região amazônica e leste do Brasil. Tem sido coletada em matas, florestas inundadas e plantações de cacau.

Material examinado: Brasil. Amazonas: Boca do Acre, G.T. Prance et al. 2292, 15.IX.1966, infl. jovem (MG). Bahia: Ilhéus, R. Voecks et al. 121, 3.VI.1985, fr. (CEPEC); idem, S.A. Mori et al. 13675, 19.IV.1981, infl. Jovem (CEPEC); idem, S.A. Mori et al. 13682, 21.IV.1981, fl. pist. (CEPEC); Santa Cruz Cabrália, S.A. Mori et al. 11859 16.V.1979, infl. jovem (CEPEC); Una, R.P. Belém \& $M$. Magalhães 1009, 18.V.1965, fl. pist. (UB).

2.5. Neea laxa Poepp. \& Endl., Nov. gen. sp. pl. 2: 45. 1838. tab. 162. Tipo: Peru, "in sylvis primaevis provinciae Maynas ad Yurimaguas. Aprili floret", Poeppig 2329 - fide Choisy (1849) (holótipo W, n.v.).

Neea rufula Mart. ex J.A. Schmidt in Mart., FI. Bras. 14(2): 368. 1872. Tipo: Rio de Janeiro, Glaziou 1110 (holótipo P!; isótipo BR!). Syn. nov.

Fig. 39

Arbustos a arvoretas, 1,0-5,0 m alt., caule 2,0$4,0 \mathrm{~cm}$ diâm.; ramos dicotômicos abertos, geralmente delgados, retos, alongados; entrenós 1,8-20,0 cm compr., os terminais em geral muito alongados. Folhas com pecíolo 0,6-5,2 cm compr., ca. 1,0 mm espessura. Laminas 15,0-31,0 X 5,2-15,3 cm, frequentemente oblongas, elípticas, ovado-elípticas, às vezes ovadas, base obtusa atenuada a arredondada, ápice obtuso, arredondado a agudo, acuminado, acúmen agudo, opostas, verticiladas nas bifurcações, em geral tanto as folhas dos pares como dos verticilos heterofilas, glabras a esparsamente pubérulas; nervuras divergindo em ângulo quase reto, sub-paralelas, salientes na face inferior, especialmente a nervura mediana, vermelhas quando vivas; folhas secas cartáceas flexíveis, verde-oliváceas a verdeamareladas, raramente verde- pardacentas, brilhantes na face superior e opacas na face inferior, as novas membranáceas. Inflorescências ca. $11,1 \times$ ca. $2,8 \mathrm{~cm}$, em geral axilares, glabras a esparsamente hírtulas, vermelhas; pedúnculo até 3,1-14,8 cm compr., em geral delgado, longo, flexível; ramos alternos a 


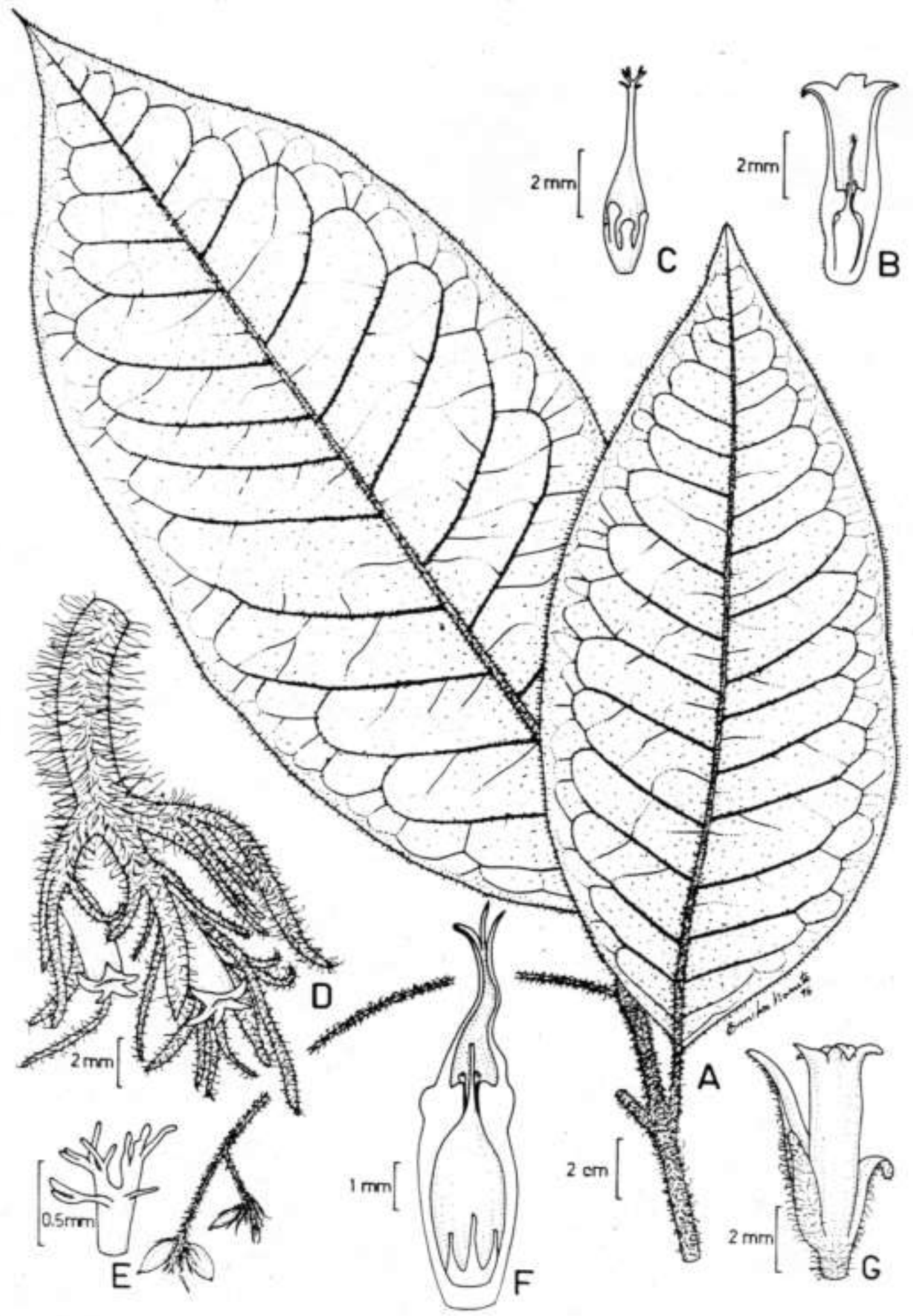

Fig. 37 - Neea hirsuta: A. Ramo de planta feminina em frutificação. B. Flor pistilada com o cálice em corte longitudinal. C. Ovário e estaminódios. D. Ramo terminal de inflorescência pistilada. E. Detalhe do estigma. F. Flor pistilada em início de frutificação, com o cálice em corte longitudinal. G. Flor pistilada com bráctea e bractéolas. (A - R. Voeks et al. 121; B-E, G S.A. Mori et al. 13682; F - R.P. Belém \& M. Magalhães 1009). 


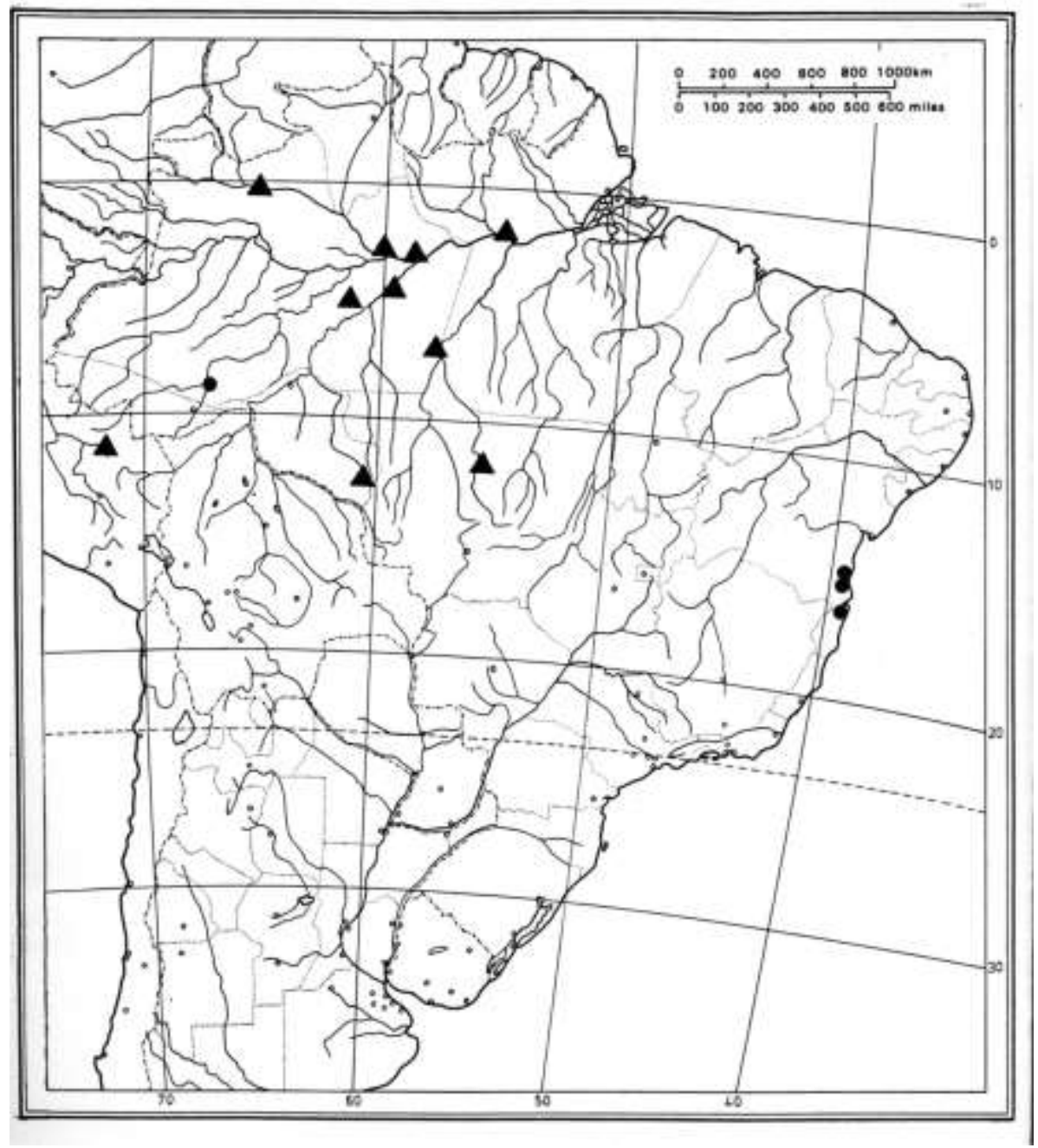

Fig. 38 - Distribuição geográfica de Neea hirsuta (círculos) e N. parviflora (triângulos).

raramente opostos, raríssimo sub-verticilados, às vezes sem brácteas, os secundários racemosos; brácteas 0,8-2,0 $\mathrm{mm}$ compr., agudas, glabras; bractéolas $0,7-1,8 \mathrm{~mm}$ compr., glabras a pouco pubérulas; botões estaminados 5,0-7,0 x 2,0-2,8 mm, obovóides alongados; flores estaminadas 5,0-10,0 x 2,0-4,0 mm, tubulosas cilíndricas, pouco pubérulas, róseas a avermelhadas, quando secas amareladas; lobos do cálice curtos; estames 7-8; flores pistiladas 4,0-5,5 x 1,5-2,0 mm, tubulosas, constrictas pouco acima do meio; lobos do cálice agudos a arredondados denticulados, membranáceos; estaminódios 6-7; estilete agudo, pouco fimbriado no ápice. Infrutescências pêndulas, pedúnculo às vezes curto ca. $1,8 \mathrm{~cm}$ compr., marrons a rubros; antocarpos 7,0-14,0 x 2,5-4,0 mm, oblongos a elipsóides, glabros a pubérulos, os maduros alaranjado-avermelhados a arroxeados; cúpula 1,3-2,0 mm compr., espessada na base, saliente e distinta quando seca.
Embora o material-tipo de $N$. laxa não tenha sido examinado, a comparação com a figura apresentada por Poeppig \& Endlicher (1838) e a chave de identificação de Standley (1937a) para as espécies peruanas de Neea permitem boa circunscrição da espécie, que é caracterizada pelas folhas oblongas, verdes quando secas e inflorescências longopedunculadas e laxas.

O espécime-tipo de Neea rufula é muito semelhante aos demais materiais de $N$. laxa, exceto pela coloração da folha seca que é verde-pardacenta a verde oliva, mas consideramos que essa diferença não justifica a manutenção de duas espécies distintas.

Pelas flores estaminadas tubulosas e cilíndricas, $N$. laxa parece ser próxima de $N$. oppositifolia e $N$. macrophylla, das quais diferencia-se pelas folhas verdes quando secas e inflorescência longamente pedunculada. Nas duas outras espécies o 


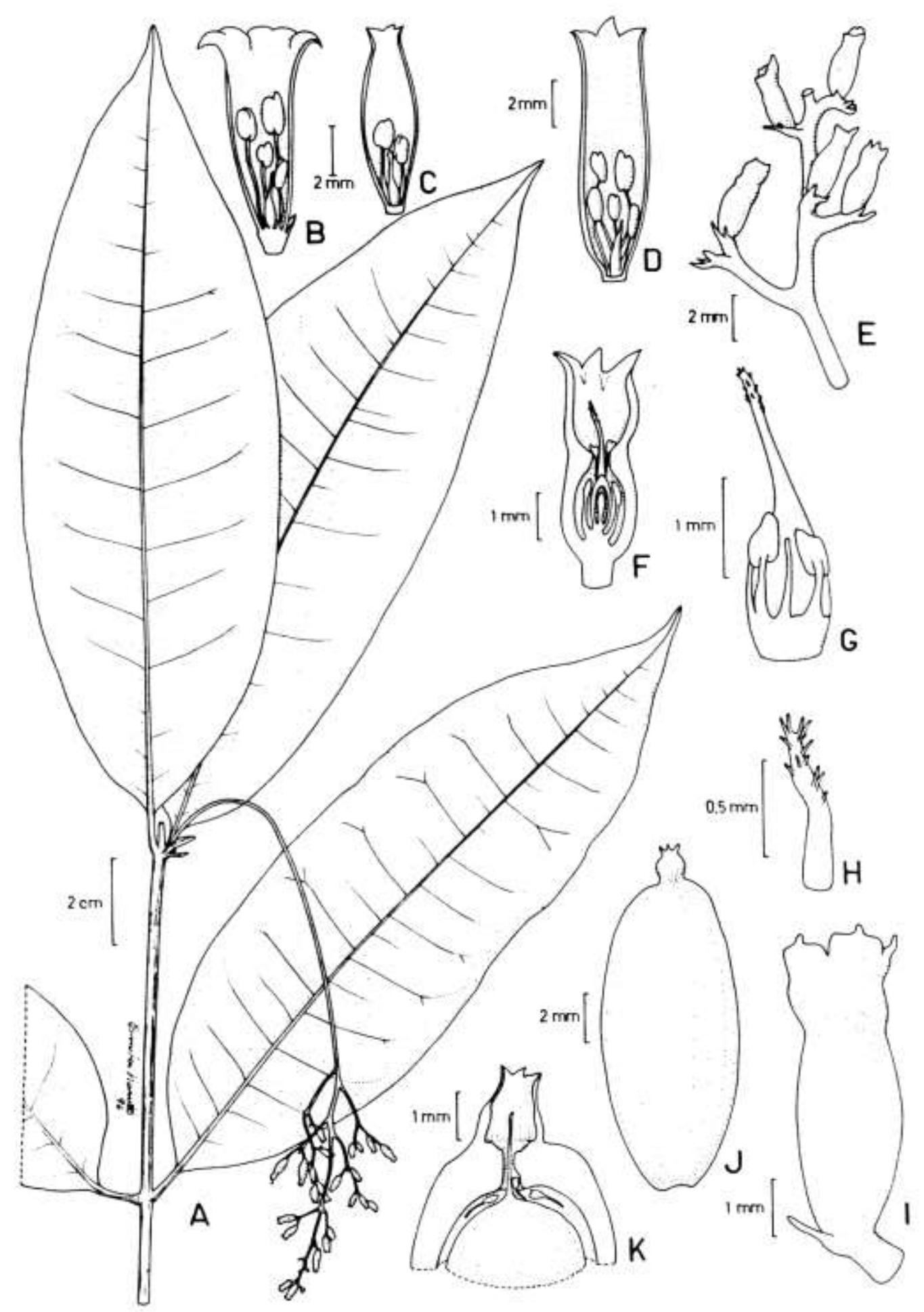

Fig. 39 - Neea laxa: A. Ramo de planta pistilada. B-D. Vários tipos de flores estaminadas em corte longitudinal. E. Ramo terminal de inflorescência pistilada; várias flores com os lobos do cálice forrageados. F. Flor pistilada em corte longitudinal. G. Ovário e estaminódios. H. Detalhe do estigma. I. Flor pistilada em início de frutificação. J. Antocarpo. K. Esquema do ápice do antocarpo em corte longitudinal. (A, E, I - J.G. Kuhlmann 1417; B - G.T. Prance et al. 13390; C - J.P.P. Carauta 5996; D - R.S. Pinheiro 1329; F-H, J-K - J.A. Kallunki e J.R. Pirani 452). 
pedúnculo da inflorescência normalmente é muito curto e inflexível. $N$. laxa poderia ser também aproximada de $N$. hirsuta, pois ambas presentam inflorescências longo-pedunculadas e flores tubulosas cilíndricas. Porém, em N. hirsuta o indumento hirsuto característico é persistente e não decíduo.

Distribuição geográfica e habitats (Fig. 40): N. laxa tem sido coletada apenas no Peru e no Brasil, nos estados do Amazonas, e disjuntamente na mata atlântica litorânea da Bahia e Rio de Janeiro (Fig. 46). Esse padrão de distribuição disjunto é compartilhado com outras espécies do gênero.

Material selecionado: Brasil. Amazonas: Humaitá, 7³1'S, 6310'W, F.N. Chagas et al. 1913, 5.VIII.1976, fr. (UEC). Bahia: Ibicaraí, $14^{\circ} 52^{\prime}$ 'S, $39^{\circ} 38^{\prime} \mathrm{W}$, J.A. Kallunki e J.R. Pirani 452, 7.II.1993, fl. pist./fr. (NY, SPF); Ilhéus, J.L. Hage e E.B. Santos 1073, 8.VII.1981, fr. (CEPEC, SPF). Rio de Janeiro: Nova Iguaçu, D. Araujo et al. 1876, 17.X.1977, bot. est. (GUA).

Peru. Tarapoto, R. Spruce 4058, 1855/56, fr. (K); Yurimaguas, J.G. Kuhlmann 1417, 15.II.1924, fl. pist. (RB).
2.6. Neea macrophylla Poepp. \& Endl., Nov. gen. sp. pl. 2: 46. 1838. (non Neea macrophylla Britton, Bull. Torrey bot. Club 27: 126. 1900). Tipo: Peru, "in sylvis provinciae Maynas", Poeppig s.n. (holótipo B "fide Standley 1937 a", n.v.).

Neea constricta Spruce ex J.A. Schmidt in Mart., FI. Bras. 14(2): 368. 1872. Tipo: Brasil, "in vicinia Santarem, prov. Pará, augusti m.flor.", R. Spruce 992 (lectótipo K!; isolectótipos BM!, P! aqui designados). Syn. nov.

Fig. 41

Nome vulgar: joão-mole (Ratter 4392).

Arbustos a árvores, 2,0-10,0 m alt., caule 5,015,0 cm diâm., liso, acinzentado; ramos distais folhosos, retos ou pouco tortuosos, muito compressos quando secos, córtex escamoso facilmente decíduo; enternós até $5,5 \mathrm{~cm}$ compr., os distais muito curtos. Folhas com pecíolo 0,9-1,5 cm compr. Laminas 6,8$11,1 \times 2,9-5,3 \mathrm{~cm}$, largo-elípticas, ligeiramente ovadas a obovadas, base geralmente aguda, raro obtusa, usualmente inequilátera, ápice obtuso a arredondado,

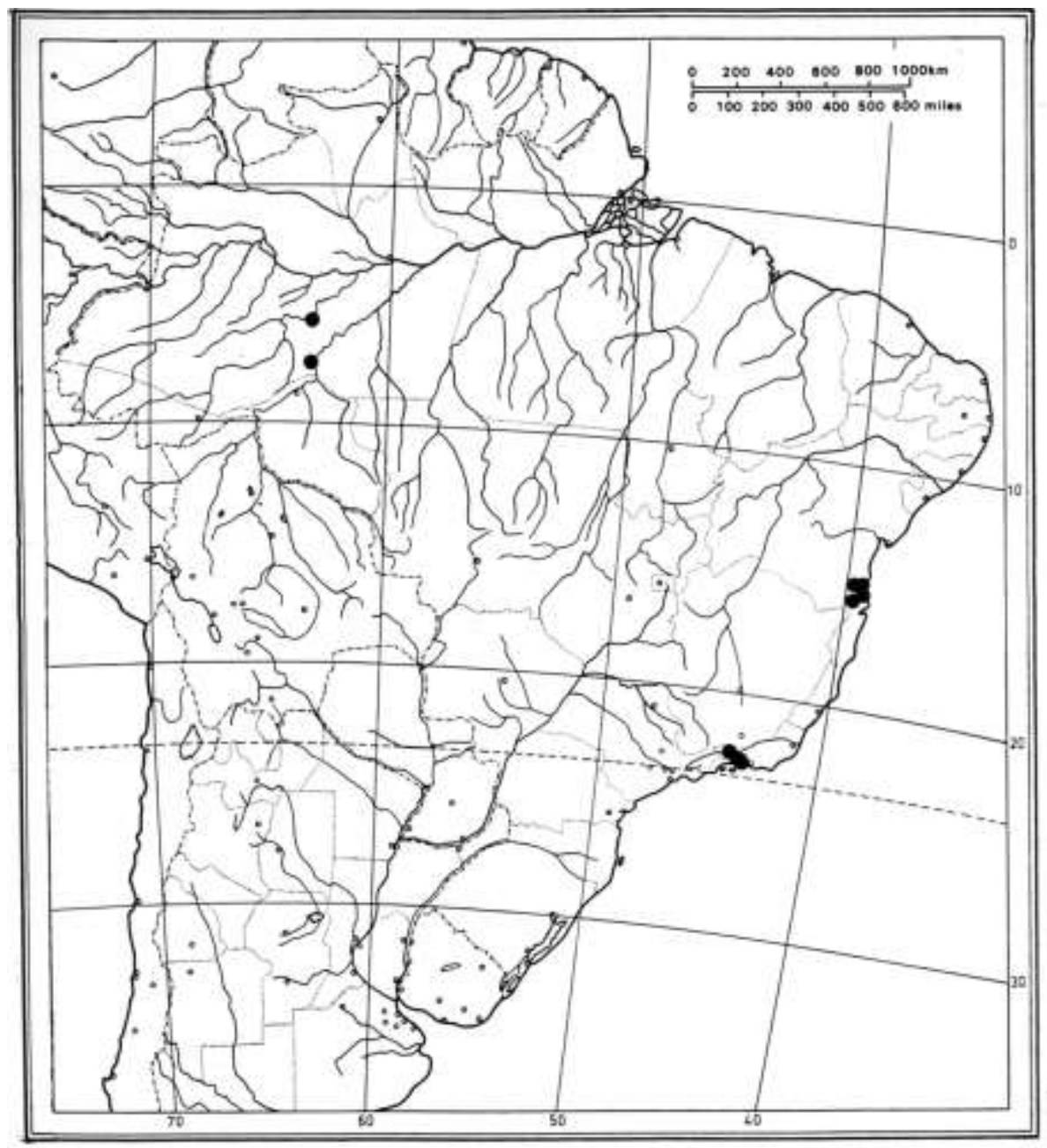

Fig. 40 - Distribuição geográfica de Neea laxa. 


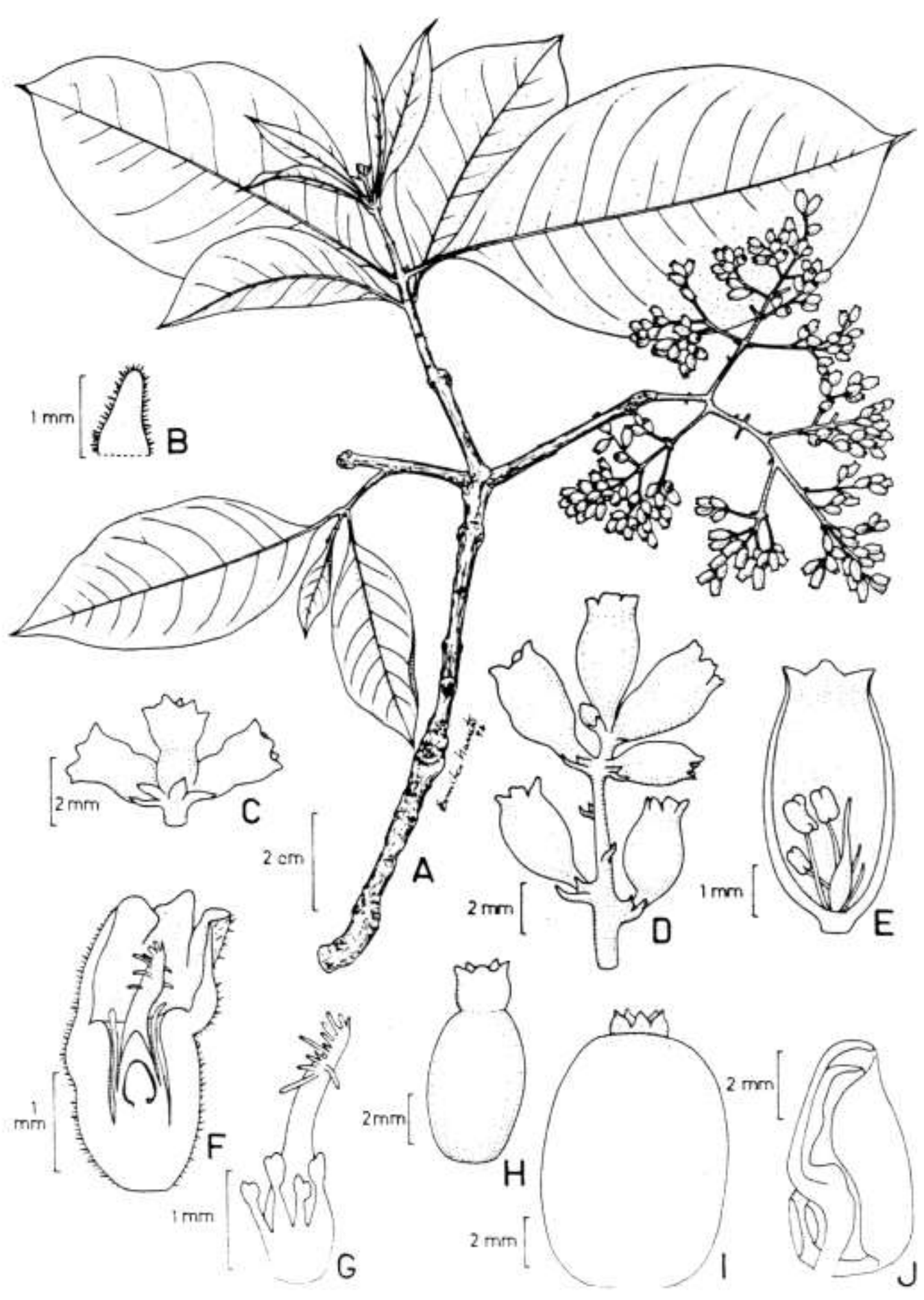

Fig. 41 - Neea macrophylla: A. Ramo de planta estaminada; B. Bráctea da cimeira terminal. C. Cimeira terminal pistilada. D. Ramo terminal de inflorescência estaminada. E. Flor estaminada em corte longitudinal. F. Flor pistilada em corte longitudinal. G. Ovário e estaminódios. H. Antocarpo jovem. I. Antocarpo. J. Embrião em corte longitudinal. (A, D-E - J.A. Ratter et al. 4392; BC, F-G - H.S. Irwin e T.R. Soderstron 7238; H-J - D. Philcox et al. 3815). 
curto-acuminado a curto-caudado, coriáceas a cartáceas, as novas elíptico-oblongas de ápice muito agudo, espessas, incurvadas, membranáceas, glabras; quando secas, pretas a marrons, brilhantes na face superior, opacas na face inferior, nervuras não ou pouco salientes, as novas enegrecidas com nervuras esverdeadas. Inflorescências 3,5-6,0 x 3,0$7,2 \mathrm{~cm}$ larg., multifloras, em geral várias no ápice de ramos pouco folhosos, indumento pubérulo ferrugíneoclaro, esparso; pedúnculos retos, 0,5-2,0 cm compr., ramos primários opostos a subopostos, ramos distais pubérulos; brácteas 0,8-3,5 x 0,5-1,5 mm, na base dos ramos primários e no meio dos ramos distais, ferrugíneas; bractéolas $0,5-1,0 \times$ ca. $0,5 \mathrm{~mm}$, pubérulas; botões estaminados oblongo-urceolados, pubérulos especialmente na base; flores estaminadas 4,0-5,5 x 2,0-3,0 mm, cilíndrico-campanuladas, às vezes pouco alargadas no meio, ápice pouco ou não constrito, fauce 1,8-2,5 mm diâm., verde-amareladas, aromáticas, lobos do cálice curto-dentiformes a arredondados, abertos; estames 8; flores pistiladas 3,0-4,5 x 2,0-2,5 mm, parte inferior curto-tubulosa, parte superior urceolada a globosa, lobos abertos, glabras; estaminódios 6-7. Infrutescências 4,5-7,0 cm compr., 4,0-8,5 mm larg., sub-lenhosas, glabras a pubérula esparsa; pedúnculo da infrutescência 1,2-3,5 $(-8,0) \mathrm{mm}$ compr.; antocarpos 5,0-17,0 x 2,5-7,5 mm, cúpula 1,5-3,5 mm alt., 1,5-3,0 mm larg., ereta, aberta, lobos do perianto espessados.

Neea macrophylla é caracterizada pelas folhas adultas glabras, subcoriáceas a cartáceas espessas, de base (ou toda a lâmina) inequilátera, inflorescências laxas e multifloras com pedúnculo curto, pouco maior que o pecíolo. A circunscrição aqui adotada está de acordo com o protólogo e com a chave de Standley (1937a) para as espécies do Perú, e confirmada pela comparação com os espécimes Argent 6827 e Krukoff 6164, identificados por este especialista. Standley (1937a) menciona folhas de até $35 \mathrm{~cm}$ comprimento e $16 \mathrm{~cm}$ de largura em exemplares peruanos da espécie.

Neea constricta foi nomeada por Spruce no herbário e posteriormente descrita por Schmidt (1872), sem indicação do número do coletor e do herbário onde estaria depositado. Foram examinadas três exsicatas com as mesmas características morfológicas, com flores estaminadas e com a mesma localidade referida no trabalho e o número Spruce 992. O espécime de (K), apesar de datado de julho de 1850 , é o espécime mais completo, com dois ramos bem preservados e com várias inflorescências. Enquanto no isolectótipo de Paris consta "agosto/1850", no do British Museum conta "julho/1850". Esses três espécimes são idênticos aos demais materiais examinados de $N$. macrophylla.

Neea macrophylla foi descrita por Britton (1900), com base em material coletado na Bolívia. Como se tratava de um homônimo posterior, teve seu nome alterado posteriormente por Standley (1931) para N. brittonii Standl. Não foi examinado o material-tipo de $N$. brittonii, porém, pela descrição e pela chave de identificação de Standley (1931b), tem várias características coincidentes com $N$. macrophylla Poepp.\& Endl. Embora Standley (1931) afirme que $N$. brittonii seria diferenciada pelas folhas glabras e inflorescências curto-pedunculadas, estes caracteres também ocorrem em $N$. macrophylla.

Distribuição geográfica e habitats (Fig. 42): N. macrophylla distribui-se na Colômbia, Peru e Brasil, onde ocorre nas Regiões Norte e Centro Oeste. Pode ocorrer desde altitudes baixas como na foz do Amazonas até a $1100 \mathrm{~m}$ de altitude, nas montanhas do Perú (Standley 1937a).

Material selecionado: Brasil. Amazonas: São Gabriel, Rio Negro, A. Ducke s.n., 8.I.1932, fr. (RB 25640). Amapá: Serra do Navio, B. Rabelo 307, 7.Il.1980, fr. (MG). Goiás: Aragarças, R.M. Harley et al. 10863, 26.X.1968, bot. pist. (UB). Mato Grosso: Xavantina, Ana Lima 381-68, 8.X.1968, fr. (IPA). Mato Grosso do Sul: Selviria, M.R. Pereira-Noronha M476, 19.XII.84, fl. pist. (HISA, HRCB). Pará: Belterra, G.A. Black 48-2347,_10.I.1948, fr. (IAC); Serra dos Carajás, C.C. Berg \& A.J. Henderson 503, 13.X.1977, bot. est. (MG, RB, UEC). Tocantins: Illha do Bananal, $10^{\circ} 30^{\prime} \mathrm{S}, 50^{\circ} 30^{\prime} \mathrm{W}$, J.A. Ratter et al. 4392, 12.IX.1980, fl. est. (K, UB, UEC).

Colômbia. Rio Caqueta/La Pedrera, A. Ducke s.n., 12.XI.1912, infl. jovem (MG 12223).

2.7. Neea madeirana Standl., Field Mus. Nat. Hist. Bot. 17(2): 189. 1937. Tipo: Brasil, Amazonas, "basin of Rio Madeira, Humayta, on plateau between Rio Livramento and Rio Ipixuna, on campinarana, nov/1934", B.A. Krukoff 7066 (holótipo F n.v.; isótipos NY n.v., K!, BM!, BR!, RB!).

Neea aeruginosa Standl., Field Mus. Nat. Hist. Bot. 17(2): 187. 1937. Tipo: Brasil, Amazonas, "São Paulo de Olivença, near Palmares, varzea land, setout/1936", B.A. Krukoff 8578 (holótipo NY n.v.; isótipos BM!, BR!, K!, P!). Syn. nov.

Neea krukovii Standl., Field Mus. Nat. Hist. Bot. 17(2): 188. 1937. Tipo: Brasil, Amazonas, "basin of Rio Madeira, Humayta, near Livramento, on terra firme, out-nov/1934", B.A. Krukoff 6836 (holótipo F n.v.; isótipos BR!, K!, M!, NY n.v., RB!). Syn. nov.

Fig. 43

Nomes vulgares: joão-mole (Standley 1937b); joão-mole-vermelho (N.T. Silva 5401).

Árvores 6,0-21,0 m alt., caule 10,0-50,0 cm diâm.; ramos adultos lenhosos, cilíndricos, não compressos quando secos, glabros ou indumento pulverulento escuro; ramos jovens quando secos enegrecidos, compressos a estriados; indumento pubérulo a viloso, ferrugíneo-escuro; entrenós aproximados ou até $4,5 \mathrm{~cm}$ compr., nós pouco espessados ou não espessados; cicatrizes foliares até 5,0 mm larg.; gemas 1,0-2,5 mm diâm., salientes, ferrugíneas a marrom-escuras. Folhas com pecíolos 0,8-5,0 cm compr., comumente longos, ferrugíneos no dorso a glabrescentes. Laminas 8,0-21,8 x 3,6-12,4 $\mathrm{cm}$, muitas vezes condensadas nos ápices dos ramos, 


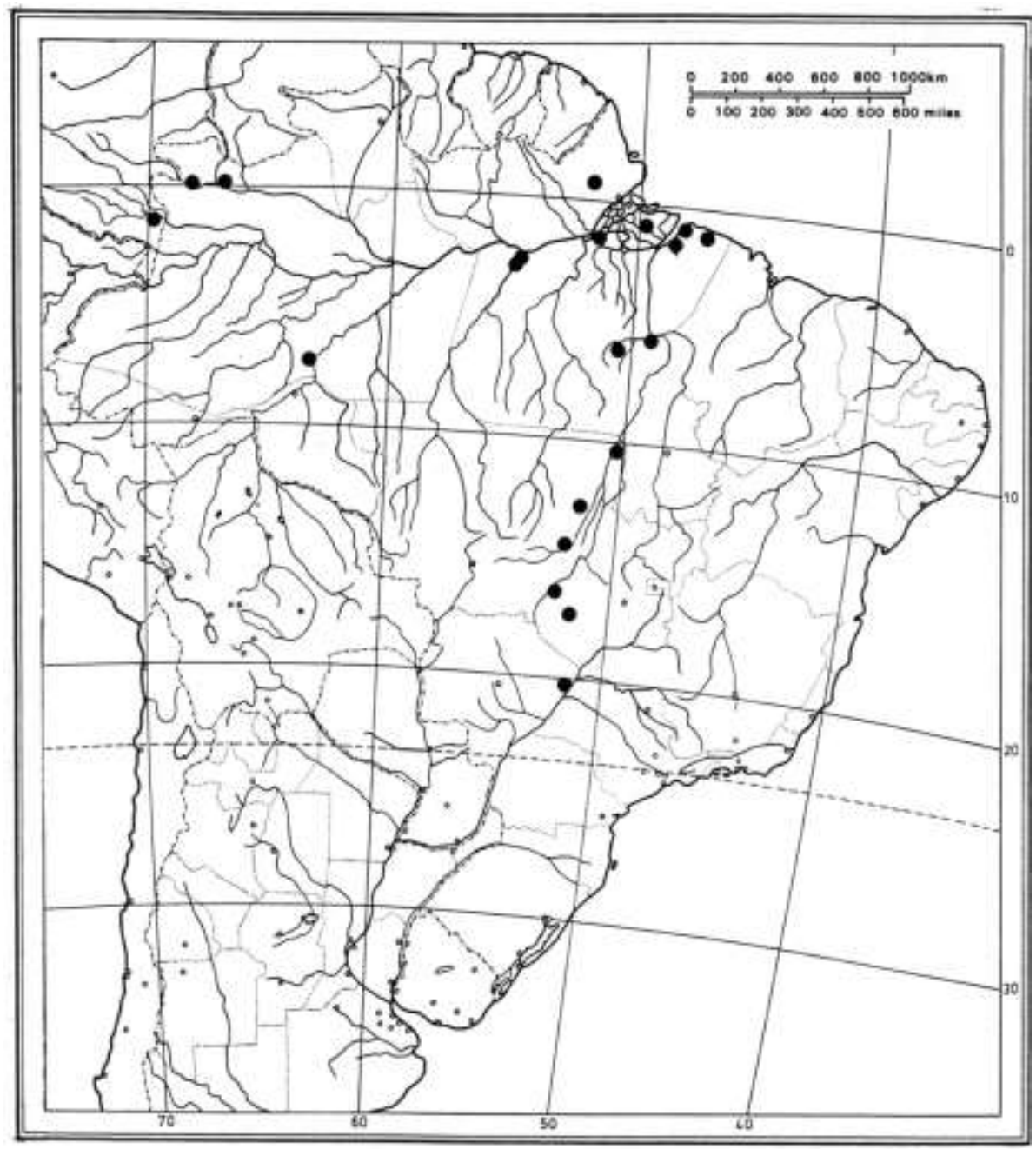

Fig. 42 -Distribuição geográfica de Neea macrophylla.

oblongo-elípticas, obovadas, elíptico-obovadas, elípticas, as menores suborbiculares, base obtusa a aguda, raramente arredondada, ápice obtuso a arredondado, curto a longo-acuminado, raramente emarginado nas folhas menores, margens às vezes de contorno irregular, pouco ou não revolutas; face superior glabra ou às vezes ferrugíneo-tomentosas nas nervuras; face inferior glabrescente a esparsamente ferrugíneo-tomentosa, indumento mais concentrado nas nervuras, raramente totalmente glabras; folhas novas às vezes totalmente tomentoso-avermelhadas nas duas faces; indumento tomentoso hírtulo, ferrugíneo-escuro, tricomas unisseriados com célula apical ferrugínea a amarelada; nervuras 7-12, salientes na face inferior, conexões não muito evidentes; quando secas cartáceas pouco flexíveis, pouco reticuladas, verde-acinzentadas a pardo-oliváceas e brilhantes na face superior, mais escuras e opacas na face inferior. Inflorescências 5,0$9,8 \times 4,4-11,0 \mathrm{~cm}$, terminais e axilares, tomentosas a pubérulas; pedúnculos 1,0-4,5 cm compr., 2,0-3,0 mm espessura, usualmente curtos e espessos; ramos alternos, opostos e subopostos, em geral patentes, raramente subverticilados em inflorescência jovens; ramos finais com cimeiras tricotômicas a aglomeradas, flores com desenvolvimento gradual; brácteas 1,0-2,5 $x$ 0,8-1,3 mm, na base dos ramos, raramente no meio dos ramos, pubérulas; bractéolas 0,5-1,0 x 0,5-0,7 $\mathrm{mm}$, pouco carnosas, pubérulas; flores estaminadas 5,5-7,5 x 3,0-3,5 mm, urceoladas, pubérulas a glabrescentes; lobos do perianto deltoides a hemisféricos, comumente reflexos; estames 8-11; flores pistiladas 2,0-5,0 x 1,5-2,5 mm, tubulosoclavadas, constritas no meio, região basal pubérula, região apical inflada, glabra; estaminódios 10; estigma agudo, franjado saliente até $0,5 \mathrm{~mm}$. Infrutescências 4,5-10,5 x 3,5-5,0 cm; pedúnculo 3,0-7,2 cm compr.; antocarpos 12,0-17,0 x 10,0-13,0 mm, glabros a pouco pubérulos na base e no ápice, muito carnosos, recobrindo a cúpula; cúpula ca. 0,8 mm alt., ca. 1,0 $\mathrm{mm}$ larg., frequentemente imersa.

Uma característica peculiar de $N$. madeirana é a coloração de suas folhas na face superior quando 


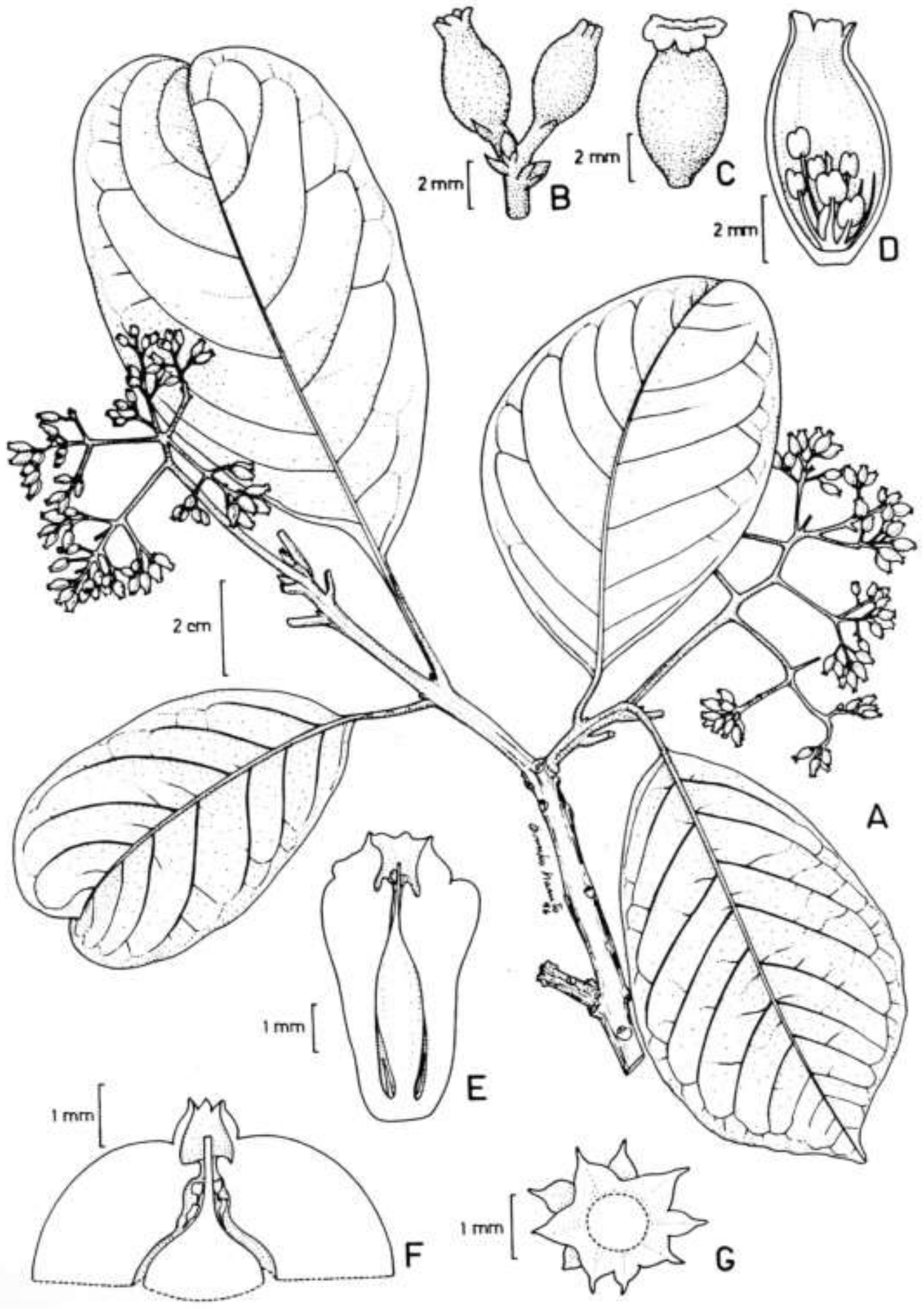

Fig. 43 - Neea madeirana: A. Ramo de planta estaminada. B. Ramo terminal de inflorescência estaminada com desenvolvimento gradual. C. Flor estaminada. D. Flor estaminada, cálice em corte longitudinal. E. Flor pistilada em início de frutificação, corte longitudinal. F. Esquema do ápice do antocarpo em corte longitudinal. G. Base dos estaminódios, na frutificação, em dois ciclos imperfeitos. (A-D - N.T. Silva 5401; E - B.A. Krukoff 6836; F-G - C.A.C. Ferreira et al. 6195). 
secas, em geral verde-acinzentadas a quase prateadas, não sendo muito evidentes as conexões das nervuras primárias próximo da margem. Também se destacam, as flores estaminadas urceoladas com ápice constricto e os lobos do cálice frequentemente bem patentes. Comparando com as demais espécies do gênero, os antocarpos de $N$. madeirana são muito carnosos e espessos e muitas vezes chegam a encobrir a cúpula apical característica típica do gênero. Nessa espécie geralmente a cúpula está um pouco imersa na polpa, que parece ser muito esponjosa. Por outro lado o fruto verdadeiro é membranáceo mas a membrana é bem resistente. Em antocarpos do material Ferreira 6195 foram encontrados 10 estaminódios, porém cinco alternos unidos entre si na base, e os outros cinco também unidos alternadamente, formando um conjunto de duas pequenas taças sobrepostas (Fig. $43 \mathrm{G}$ ).

Neea madeirana, $N$. aeruginosa e $N$. krukovii foram publicadas por Standley (1937b) no mesmo ano em que publicou as Nyctaginaceae na série da Flora do Peru, mas nenhuma das três espécies coletadas em áreas próximas da Amazônia brasileira aparecem nesta obra. Segundo esse autor, N. madeirana seria "notável pelas folhas grandes e pelo abundante tomento ferrugíneo em todas as partes da planta" e $N$. krukovii seria "notável pelas folhas grandes e excepcionalmente estreitas, muito lustrosas na face superior e textura quase coriácea".

A análise dos materiais-tipo das três espécies, mostrou que Neea aeruginosa diferencia-se ligeiramente de $N$. madeirana pelo pecíolo mais curto e pelo indumento um pouco menos ferrugíneo, mas pode ser incluído perfeitamente dentro da variabilidade de $N$. madeirana, sendo certamente um exemplar com folhas um pouco mais velhas. Por sua vez, o materialtipo de $N$. krukovii diferencia-se de $N$. madeirana apenas pela ausência total de indumento, que nos demais materiais examinados é relativamente constante, mesmo que às vezes restrito apenas à nervura mediana na face inferior. As folhas "excepcionalmente estreitas" mencionadas por Standley (1937b) ocorrem em alguns isótipos de $N$. krukovii como aqueles depositados em M e K, porém, 0 isótipo de BR mostra folhas obovadas iguais às de $N$. madeirana. Assim, nesse trabalho os binômios $N$. aeroginosa e $N$. krukovii foram sinonimizados em $N$. madeirana.

A espécie mais similar com $N$. madeirana é $N$. obovata, por portarem o mesmo tipo de indumento e apresentarem as folhas geralmente obovadas. As duas espécies diferem especialmente pelas flores estaminadas que são urceoladas de ápice constricto e com estames atingindo apenas a metade do cálice em $N$. madeirana, enquanto em $N$. obovata são muito pequenas, curto-campanuladas, e com estames atingindo a borda do cálice, ficando visíveis na fauce.

Distribuição geográfica e habitats (Fig. 44): A espécie tem distribuição na Bolívia e no Brasil, onde foi coletada no Amazonas, Pará, Rondônia, Mato Grosso, Amapá e Maranhão, em florestas de terra firme e florestas de encosta mais secas.

Material selecionado: Brasil. Amapá: Camaipi, $00^{\circ} 0^{\prime} \mathrm{N}, 51^{\circ} 37$ 'W, S.A. Mori et al. 16540,12.X.1983, bot. est. (K, MG). Amazonas: Manaus, A. Ducke 1201, 10.VII.1941, infl. jovem (MG, R, RB); Manicoré, rio Madeira, C.D.A. Mota s.n., 19.VIII.1976, infl. jovem (HRB 6474). Maranhão: Bacabal, $04^{\circ} 17^{\prime}$ S, $45^{\circ} 08^{\prime}$ W, D.C. Daly et al. 388, 30.IX.1980, infl. jovem (MG). Mato Grosso: Sinop, $11^{\circ} 55^{\prime} \mathrm{S}, 55^{\circ} 20^{\prime} \mathrm{W}$, C.A.C. Ferreira et al. 6195, 20.IX.1985, fr. (MG). Pará: Almeirim, N.T. Silva 5401, 15.VIII.1979, fl. est. (MG). Rondônia: Belmonte, M.R. Cordeiro 745, 8.IX.1975, fl. est. (MG).

Bolívia. Pando, G.T. Prance et al. 6492, 26.VII.1968, estéril (R).

2.8. Neea obovata Spruce ex Heimerl, Jber. StOberrealsch. 23: 38. 1897. Tipo: Brasil, "Brasília bor., S. Carlo ad Rio Negro", masc., Spruce 3128 (lectótipo K!, ramo com flores estaminadas; isolectótipos $\mathrm{BM}$ !, $\mathrm{BR}$ !, $\mathrm{K}$ !, $\mathrm{P}$ !, RB! aqui designados).

Pisonia breviflora Huber, Bol. Mus. Paraense Emilio Goeldi bot. 5(2): 348. 1909. Tipo: Brasil, Rio Mapuera, campinarana a NE do Taboleirinho, 12.XII.1907, A. Ducke 9112 (holótipo MG n.v.; isótipo RB!). Syn. nov.

Fig. 45

Nome vulgar: joão-mole (N.T. Silva 5417)

Arbustos a árvores, 2,5-29,0 m alt., às vezes desfolhados, caule ca. $3,5 \mathrm{~cm}$ diâm.; ramos adultos lenhosos, retos ou pouco tortuosos, córtex quebradiço, avermelhado; ramos novos estriados quando secos, às vezes compressos e enegrecidos, pubérulos especialmente nos nós; entrenós 1,5-4,7 cm compr. quando não aglomerados; cicatrizes cordadas 0,8-2,0 mm larg.; gemas até $1,0 \mathrm{~mm}$ larg., ferrugíneas a enegrecidas quando secas. Folhas com pecíolo 0,3$2,3 \mathrm{~cm}$ compr., às vezes pouco ferrugíneo-pubérulo no dorso. Laminas $6,0-12,4 \times 3,1-6,5 \mathrm{~cm}$, opostas a fasciculadas, obovadas, oblongo-obovadas, orbiculares a elíptico-orbiculares, às vezes subrômbicas, base aguda a obtusa, raramente arredondada, atenuada até quase a base do pecíolo, ápice arredondado a obtuso, glabras a pubérulas nas nervuras; quando secas, cartáceas, flexíveis, reticuladas, pardas ou marrom a cobre-avermelhado, brilhantes na face superior, opacas na face inferior; nervuras 12-18, aproximadas, subparalelas, salientes especialmente na face inferior, margens recurvadas. Inflorescências 2,5-7,3 x 1,7-6,6 cm, axilares e terminais, muitas vezes terminais em ramos curtos gemados, pouco a muito pubérulo-ferrugíneas; pedúnculos $2,4 \mathrm{~cm}$ compr., ramos primários alternos ou dicotômicos, oblíquos, raramente subverticilados em inflorescências novas; ramos distais racemosos; brácteas 0,4-1,7 mm compr., na base dos ramos, pubérulas a glabrescentes, decíduas; bractéolas 0,3$0,5 \times$ ca. $0,7 \mathrm{~mm}$, pubérulas; botões estaminados 1,5 - 


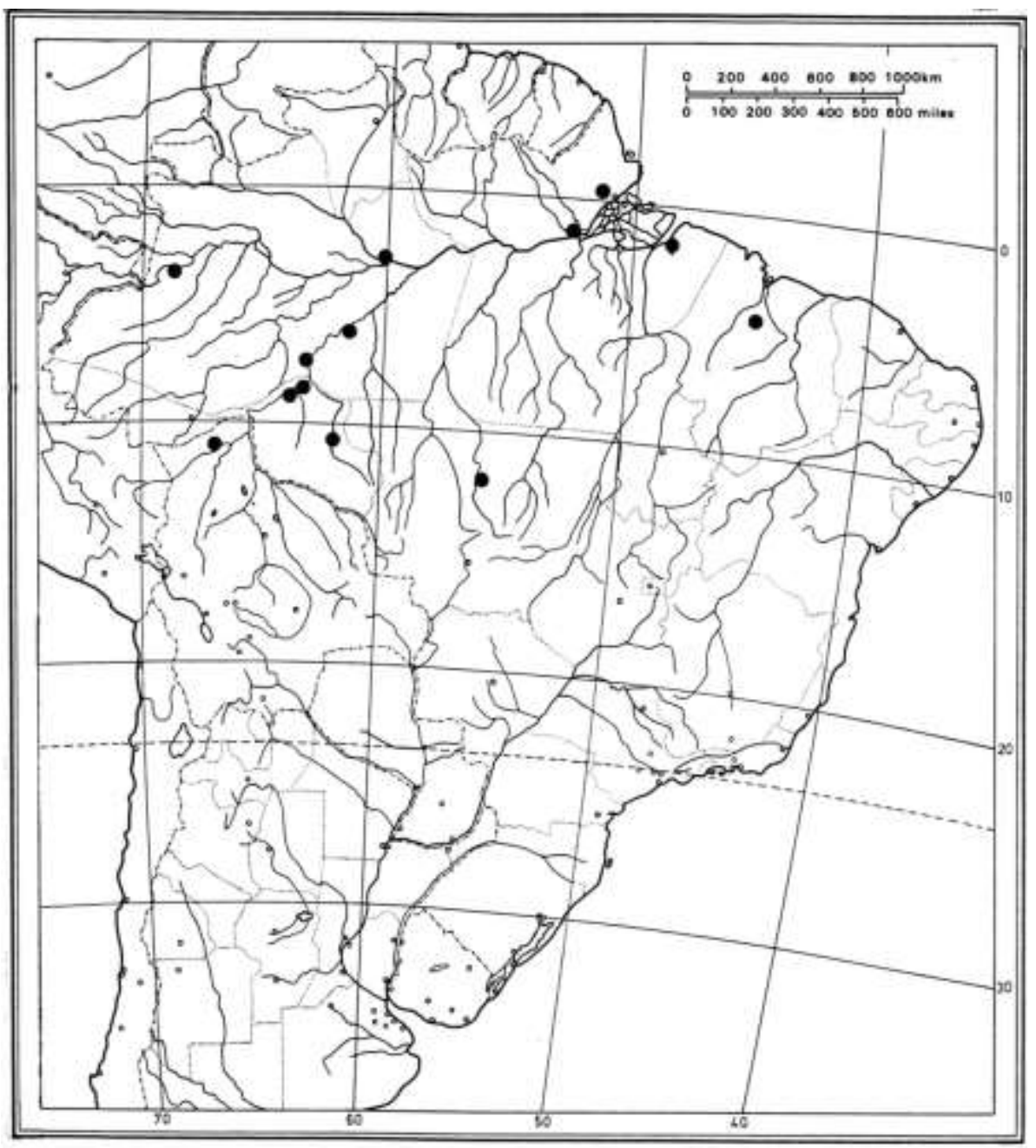

Fig. 44 - Distribuição geográfica de Neea madeirana.

2,5 x 1,0-1,8 mm, globosos e pouco alongados, ápice em geral arredondado, glabros a ferrugíneos na base; flores estaminadas 1,8-2,6 x 2,0-2,5 mm, campanuladas, perfumadas; lobos do cálice arredondados a retangulares, internamente pouco papilosos, às vezes denticulados no ápice; estames 67 , verdes, filetes pouco sinuosos; botões pistilados 1,8-2,2 $x$ ca. 1,0 mm; flores pistiladas 2,0-3,0 x 1,3-1,5 $\mathrm{mm}$, tubulosas na região basal, subglobosas na região apical, ápice aberto, lobos do cálice arredondados a truncados, internamente muito papilosos, denticulados ou não no ápice; estaminódios 7-8; estigma franjado. Infrutescências ca. $5,0 \times$ ca. $3,2 \mathrm{~cm}$, pedúnculo $2,8 \mathrm{~cm}$ compr.; antocarpos 3,0-3,5 x ca. 2,5 mm larg.; cúpula apical 0,5-1,0 mm alt., 1,0-1,8 mm larg., aberta, pouco inflada.

Ao descrever N. obovata, Heimerl (1897) baseando-se em Spruce 3128 e com dois locais de coleta "S. Carlo ad Rio Negro" e referiu que encontrou apenas inflorescências estaminadas. Foram localizadas e examinadas 14 exsicatas numeradas como Spruce 3128, e em apenas nove dessas ocorriam flores estaminadas. Provavelmente houve um erro na distribuição dos espécimes de Spruce 3128. Nas etiquetas de 13 exsicatas examinadas, consta em algumas "San Carlo", e nas outras "flum. Guainia", sendo que San Carlos localiza-se na margem do rio Guainia, na Venezuela. As exsicatas provenientes de San Carlos são geralmente de exemplares estaminados, e as provenientes do rio Guainia são geralmente de exemplares pistilados em início de frutificação. Em uma exsicata do herbário $\mathrm{K}$ contém dois ramos com várias inflorescências estaminadas e um desenho a lápis da flor estaminada em corte longitudinal. Sob cada um dos dois ramos estaminados deste espécime há uma etiqueta, constando em uma "3128, San Carlos, oct/53, Spruce" e na outra "3128, San Carlos, nov/53, Spruce". Em Kew há uma outra exsicata que contém três ramos, sendo dois com flores estaminados e um em início de frutificação. Talvez seja essa a exsicata estudada 


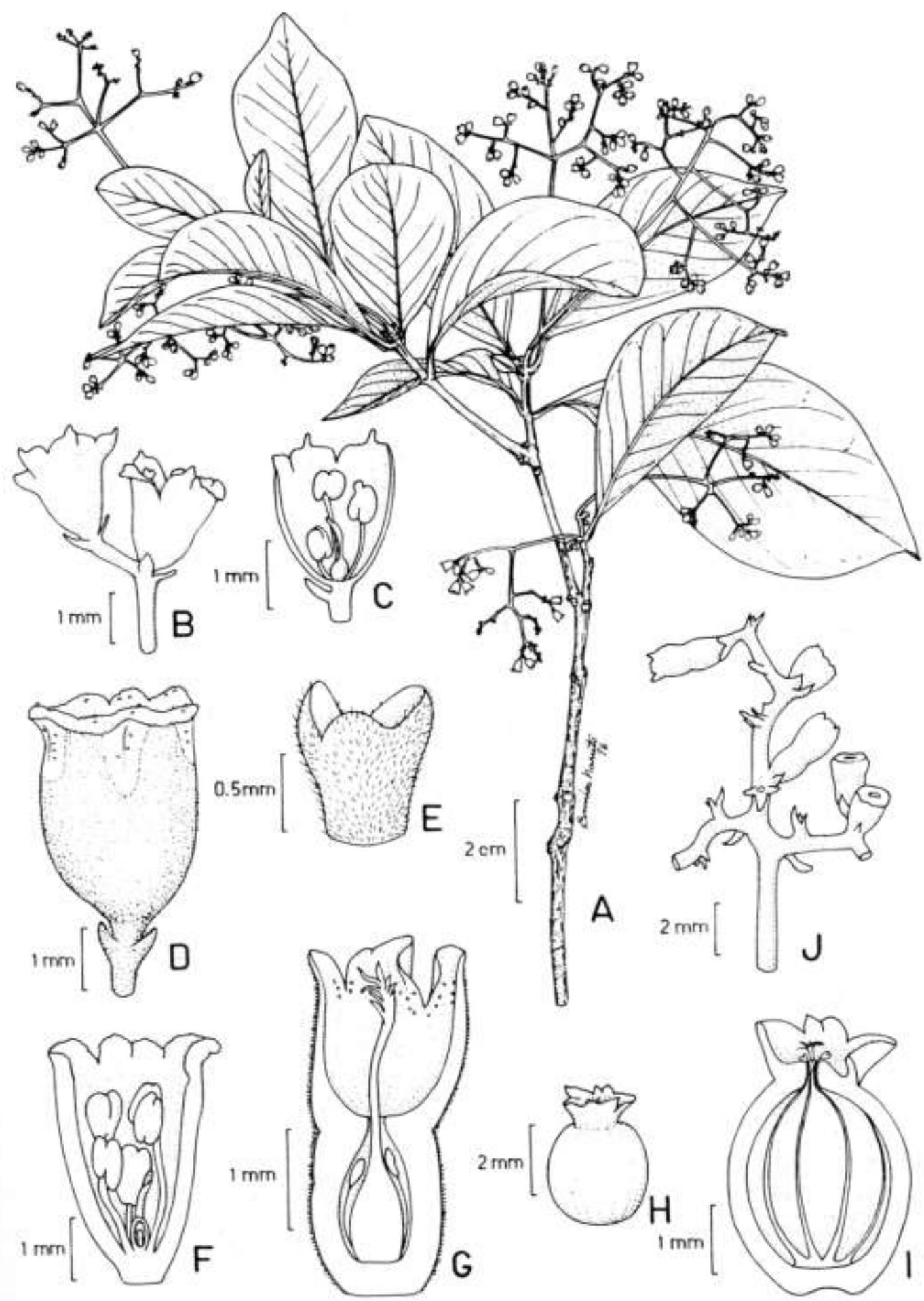

Fig. 45 - Neea obovata: A. Ramo de planta estaminada. B. Ramo terminal de inflorescência estaminada. C. Flor estaminada em corte longitudinal. D. Flor estaminada. E. Brácteas e bractéolas das flores. F. Flor estaminada em corte longitudinal. G. Flor pistilada em corte longitudinal. H. Antocarpo. I. Antocarpo com as paredes em corte longitudinal mostrando fruto e estaminódios. J. Ramo terminal da inflorescência pistilada; várias flores com ápice pastoreado. (A, D-F - J.R. Pirani et al. 2580; B-C - E. Pereira 1850; G, J - G.A. Black 50-8767; H-I - A. Ducke s.n. HAMP 15836). 
originalmente por Spruce, pois sob o ramo com frutos jovens há uma etiqueta contendo "3128, Neea obovata sp.n., arbor parva 15-20 pedalis... fluvii Guainia, nov/53, Spruce". Sob o ramo estaminado a etiqueta informa "3129 (merely a form of 3128) ... San Carlos, oct/53, Spruce". Nesse trabalho, selecionamos como lectótipo esse espécime de $\mathrm{K}$, e o ramo com flores estaminadas. Provavelmente, Heimerl (1897) não deve ter visto esta exsicata porque em sua descrição não consta altura da árvore e nem flor pistilada ou fruto.

Uma característica marcante de $N$. obovata são as flores estaminadas muito pequenas quando comparadas com as das outras espécies do gênero, curto-campanuladas com os estames inclusos, tendo filetes de extensão quase igual à do cálice deixando as anteras visíveis na fauce não constricta. Trata-se da espécie de Neea que mais se assemelha às de Guapira. Em Guapira os estames são longo-salientes enquanto que em $N$. obovata os estames são da altura do cálice mas não salientes. A permanência de $N$. obovata neste gênero é reforçada por outros caracteres, como os botões estaminados de ápices arredondados e não estreitados na base, estigma incluso e pouco franjado, e antocarpos com cúpula apical ligeiramente inflada.

Os espécimes de $N$. obovata procedentes do Ceará podem ser confundidos vegetativamente, com alguns exemplares de Guapira laxa coletados em área de caatinga, pelas folhas pequenas, obovadas a subrômbicas com indumento ferrugíneo e pela ocorrência de gemas já um pouco desenvolvidas com duas minúsculas folhas.

Distribuição geográfica (Fig. 46): N. obovata é conhecida apenas da Venezuela e do Brasil, nos estados do Amazonas, Pará, Mato Grosso e disjuntamente no Ceará.

Material selecionado: Brasil. Amazonas: Rio Preto, Matupiry, R.L. Froes 22837, 13.I.1947, infl. jovem (IAC); Tefé, J.M. Pires 1320, 20.X.1948, bot. est. (IAC). Ceará: São Tiangui, J.R. Pirani et al. 2580, 28.I.1990, fl. est. (SPF). Mato Grosso: Xavantina, H.S. Irwin \& T.R. Soderstron 6358, 26.IX.1964, bot. est. (MBM). Pará: Almeirim, N.T. Silva 5417, 16.l.1980, fr. (MG); Vigia, G.A. Black 50-8767, 22.I.1950, fl. pist. (UB).

Venezuela. $03^{\circ} 40^{\prime} \mathrm{N}, 66^{\circ} 50^{\prime} \mathrm{W}, O$. Huber 1691 , 28.II.1978, fl. est. (K).

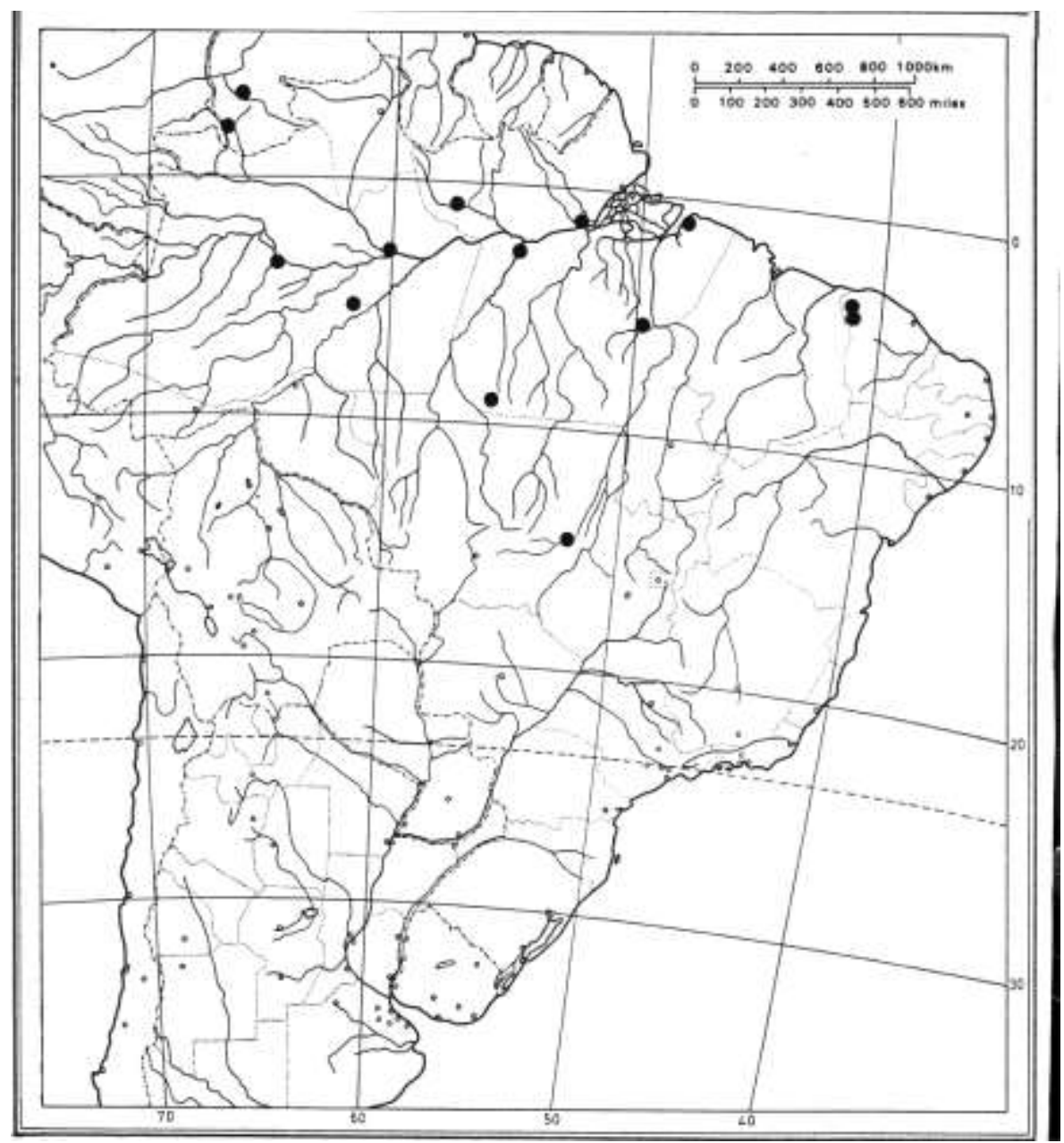

Fig. 46 - Distribuição geográfica de Neea obovata. 
2.9. Neea oppositifolia Ruiz \& Pav., Syst. veg. fl. Peruv. Chil.: 91. 1798. Fl. peruv. 4: tab. 329. 1830. Tipo: Peru, "in Peruviae Silvis Pillao ad Chacauassi floret octobri et novembri", Pavon s.n. (holótipo MA n.v.; isótipos $\mathrm{K} !, \mathrm{P}$ !).

Neea rosea Mart.ex J.A.Schmidt in Mart., FI. Bras. 14(2): 366. 1872. Tipo: Brasil, "in ripa fl. Japura non infrequens ad Manacurii, prov. Alto Amazonas", fl. est., Martius 3134 (lectótipo M!; isolectótipos M! aqui selecionados). Syn. nov.

Neea compressa J.A. Schmidt in Mart., FI. Bras. 14(2): 366. 1872. Tipo: Brasil, "in sylvis ad Coari et in roridis marginibus fluvii Japura, prov. Alto Amazonas", fl. pist./fr., Martius 3133b (holótipo M!; isótipos M!). Syn. nov.

Neea spruceana Heimerl, Notizbl. Bot. Gart. Mus. Berl. 6: 131. 1914. Tipos: Peru, "dep. Loreto, Tarapoto", fl. est., Spruce 4858 (lectótipo P!. isolectótipo BR! aqui selecionados). Syn. nov.

Fig. 47

Nomes vulgares: castanha-de-arara (J.B. Andrade 3340); joão-mole (I.L. Amaral 270).

Arbustos a árvores 3,0-20,0 m alt., caule 3,0$40,0 \mathrm{~cm}$ diâm., ramos velhos lenhosos, cilíndricos, normalmente retos, dicotômicos abertos; os novos pouco ou não compressos, negros ou pardos quando secos; entrenós 1,2-7,0 cm compr., nós geralmente espessados. Folhas com pecíolo 0,5-3,0 cm compr. Laminas 4,9-17,1 x 2,3-8,6 cm, opostas a subopostas, geralmente elíptico-obovadas, menos frequentemente orbiculares, ovadas, elíptico-oblongas, quase sempre ligeiramente obovadas ou com largura maior pouco acima do meio, base aguda a obtusa, raramente arredondada, ápice obtuso a arredondado, raramente agudo, curto-acuminado a caudado, cauda ou acúmen agudo a obtuso, às vezes curvos; as jovens glabras ou com indumento pubérulo-ferrugíneo esparso, mais condensado perto da nervura mediana, as adultas em geral glabras; quando secas, as novas membranáceas e enegrecidas, as adultas cartáceas, pardas a marrons, nervuras pouco mais claras, salientes na face inferior, especialmente a nervura mediana. Inflorescências 2,0-7,5 x 1,5-4,8 cm, axilares e terminais em ramos curtos gemados, ou terminal no ramo do ano, glabra a pubérula especialmente nas articulações, avermelhados; pedúnculos $0,8-4,3 \mathrm{~cm}$ compr., ramos alternos dicotômicos ou opostos, em geral patentes, ferrugíneos, os distais tricotômicos; brácteas 1,0-2,5 x 0,3-0,8 mm, em geral na base dos ramos distais, deltóide-lanceoladas, pouco carnosas, pubérulas; bractéolas $0,5-2,0 \times$ até $0,7 \mathrm{~cm}$, deltóides a linear-deltóides, base alargada, pubérulas. Botões estaminados 3,0-5,0 x ca. 1,5 mm, elipsóides; flores estaminadas 4,0-9,0 x1,5-3,0 $\mathrm{mm}$, tubulosocampanuladas, ápice não constricto, fauce 1,5-2,5 mm larg., pubérulas a glabras, creme-amareladas a avermelhadas; lobos do perianto até 2,2 $\mathrm{mm}$ compr., eretos a pouco reflexos; estames 5-13; flores pistiladas 3,0-6,0 × 1,5-2,0 mm, tubulosas, pubérulas na base, lóbulos avermelhados; estaminódios 6-9; estigma agudo, às vezes pouco espessado ou pouco fimbriado no ápice, saliente até $0,6 \mathrm{~mm}$. Infrutescências 4,5-8,0 x 4,5-6,0 cm, terminais, em geral pêndulas; pedúnculo $2,1-4,5 \mathrm{~cm}$ compr.; antocarpos 9,0-13,0 x 4,0-7,0 mm, em geral glabros, avermelhados; cúpula apical 1,0-2,5 x 1,4-2,3 mm, espessada, geralmente fechada; estigma comumente não saliente.

Embora o protólogo de Neea oppositifolia traga descrição muito curta, que não permite qualquer identificação segura, a ilustração é excelente e muito fiel ao isótipo examinado no herbário de Paris. Segundo Stafleu \& Cowan (1983) o quarto volume da "Flora Peruvianae et Chilensis" de Ruiz \& Paven, com as tábulas 326-425, não foi distribuído por estes autores, mas as primeiras referências as tábulas deste volume datam de 1830 . A publicação final desta obra ocorreu entre 1854-1857. Portanto a tábula 329 referente a $N$. oppositifolia é anterior a qualquer outra descrição neste gênero, pois suas primeiras espécies, após Ruiz \& Pavon (1798), foram publicadas em "Nova Genera ac Species Plantarum" por Poeppig \& Endlicher (1838). A espécie Milscherlichia spectabilis Kunth, espécie duvidosa mas com certeza pertencente a Neea, também é posterior (Kunth 1832).

Neea rosea e $N$. compressa foram descritas por Schmidt (1872) que se baseou em síntipos coletados na Amazonia e no Leste do Brasil. O síntipo de $N$. rosea e formado por Martius 3134 que o herbário M possui quatro exsicatas, e Riedel 667 coletado no Rio de Janeiro, cujo espécime examinado do herbário $P$, possui estames salientes $e$ inflorescência verticilada, devendo ser redeterminado como Guapira opposita. Os espécimes coletados por Martius foram incluídos como parte da variação encontrada em $N$. oppositifolia, sendo $N$. rosea sinonimizada nesse trabalho, apesar de apresentarem ramos muito lenhosos e não tão patentes, características não frequente na maioria dos indivíduos de $N$. oppositifolia. Entretanto, tais espécimes apresentam 0 mesmo tipo de inflorescência, mesma organização das flores estaminadas e folhas com formato similar aos encontrados nos isótipos de $N$. oppositifolia examinados, apesar das folhas serem glabras. Nesse trabalho Neea rosea foi lectotipificada com base em um dos espécimes coletados por Martius, sendo os três restantes relacionados como isolectótipos.

O material-tipo de $N$. compressa, Martius 3133b, possui cinco exsicatas depositadas em $M$, todas de plantas pistiladas. É possível que esses espécimes sejam provenientes de uma planta feminina, da mesma população onde foi o coletado o exemplar com flores estaminadas utilizado para a descrição de $N$. rosea. O "fruto piriforme" descrito por Schmidt (1872) refere-se na verdade à flor pistilada em inicio de frutificação, já um pouco alongada mas ainda não espessada.

Neea spruceana foi descrita por Heimerl (1914) com base em três sintipos coletados no Peru, e a descrição original inclui a descrição das flores estaminadas, das flores pistiladas e dos frutos. Foi 


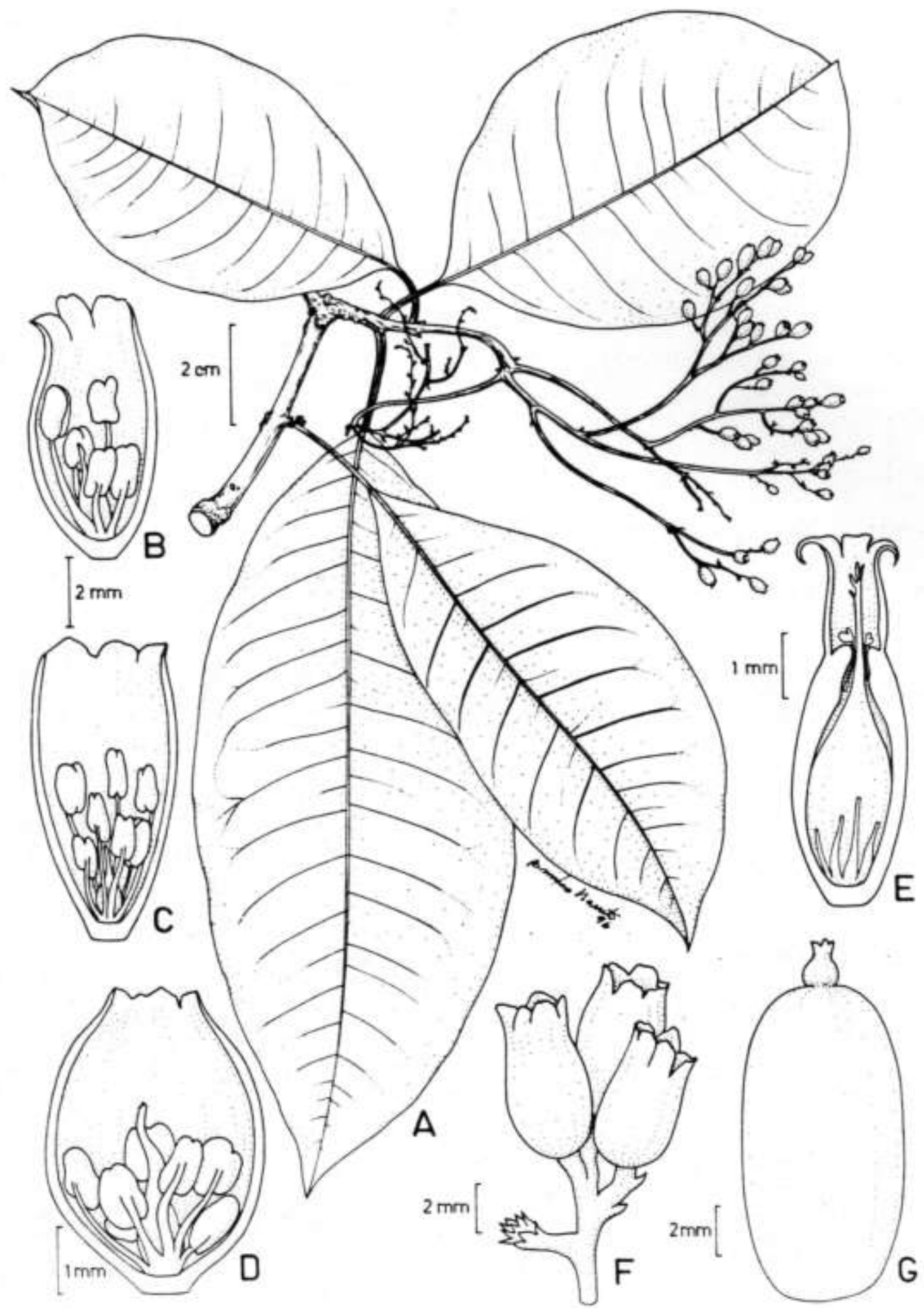

Fig. 47 - Neea oppositifolia: A. Ramo de planta estaminada. B-D. Flores estaminadas com o cálice em corte longitudinal. E. Flor pistilada com o cálice em corte longitudinal. F. Ramo terminal da inflorescência estaminada. G. Antocarpo. (A, D - Guerra s.n. RB 47551; B, F - J.G. Kuhlmann 109; C - M. Silva 1895; E - S. McDaniel \& M. Rimachi 17608; G - S. Mori et al. 8980). 
escolhido como lectótipo o espécime Spruce 4858, de flores estaminadas e depositado em $\mathrm{P}$, que inclui a localidade de coleta do espécime. Os espécimes examinados incluídos em $N$. spruceana pelas folhas obovadas a oblongo-obovadas, são semelhantes aos materiais estudados de $N$. oppositifolla contudo suas flores estaminadas são um pouco menores que a média, de 4 a 6 mm comprimento. Heimerl (1914) descreveu $N$. spruceana com flores amarelas, diferenciando-a de $N$. rosea com coloração avermelhada. Apesar dessa diferença, as demais semelhanças morfológicas não indicam possibilidade de distinção de duas espécies com base nesse caráter, que varia em diversas espécies, como em $N$. theifera cuja coloração do cálice varia de amarela a avemelhada.

Choisy (1849) coloca N. divaricata Poepp.\& Endl. como sinônimo de $N$. opposifolia, no que foi seguido por Heimerl (1897). Já Standley (1937a), na Flora do Peru, comenta que $N$. divaricata ocorre na Amazônia da Colombia e do Brasil, e diferencia-a de N. oppositifolia pelas folhas glabras. Não examinamos o material-tipo de $N$. divaricata, mas pela descrição original, e pela descrição e diferenciação apresentadas em Standley (1937a) é muito provável que seja efetivamente um sinônimo de $N$. oppositifolia. Corroborando esta suposição, alguns dos materiais incluídos nesse trabalho como $N$. oppositifolia, por exemplo Krukoff 6282, Krukoff 6641 e Krukoff 6695, foram identificados por Standley como $N$. divaricata. Estudos posteriores abrangendo todas as espécies sul-americanas deverão resolver esta controvérsia.

A espécie mais próxima de $N$. oppositifolia parece ser N. macrophylla Poepp.\& Endl., pelo tipo de inflorescência relativamente curto-pedunculada e flores estaminadas tubulosas de ápice não muito constricto. As diferenças entre estas duas espécies são tênues. Em $N$. oppositifolia as folhas são geralmente obovadas, de base aguda quase sempre equilátera, nervuras bem salientes na face inferior especialmente a nervura mediana, e as folhas adultas quando secas são cartáceas e pardas e os pedúnculos das inflorescências variam de 0,8 a 4,3 cm de comprimento, enquanto em $N$. macrophylla as folhas são predominantemente ovadas a elípticas, de base aguda em geral inequilátera, as nervuras não são salientes, e as folhas adultas são subcoriáceas, espessas e negras quando secas e os pedúnculos das inflorescências são bem curtos, variando de 0,2 a 2,0 $\mathrm{cm}$ comprimento. Mesmo exemplares em frutificação de $N$. oppositifolia apresentam folhas não tão espessas quanto as de $N$. macrophylla.

Distribuição geográfica (Fig. 48): N. oppositifolia é restrita à bacia amazônica.

Material selecionado: Brasil. Acre: Lucania, P.J.M. Maas et al. 12935, 14.V.1971, fl. pist. (K). Amazonas: Itapiranga, C.A. Cid et al. 677, 24.VIII.1979, fl. est. (R). Mato Grosso: Aripuanã, J.B. Andrade 3340, 5.IX.1976, infl. jovem (UEC). Pará: Serra dos Carajás, C.C. Berg et al. BG-537, 15.X.1977, fl. est. (RB, UEC). Rio de Janeiro: Rio de Janeiro, cultivada, Guerra s.n., 14.VII.1942, fl. est. (RB 47551). Rondônia: Alvorada d'Oeste/Costa Marques, M.G. Silva 6524 , 29.VI.1983, fl. pist. (MG). Roraima: Tepequem, G.T. Prance et al. 4373, 13.II.1967, fr. (R).

Guiana Francesa. Belison/Cayenne, S.A. Mori et al. 8980, 23.I.1977, fr. (RB).

Peru. Maynas, S. McDaniel \& M. Rimachi 17608, 7.VIII.1973, fl. pist. (RB).s. loc. out/1902, fl. est., Ule 6498 (parte do sintipo de N. spruceana, K!); ut/1902, fl. pist., Ule 6499 (parte do sintipo de N. Spruceana, K!).

2.10. Neea ovalifolia Spruce ex J.A.Schmidt in Mart., FI. Bras. 14(2): 368. 1872. Tipo: Pará, 6.I.1830, fl. pist.,fr., Burchell 10011-5 (lectótipo K!, isolectótipos P!, BR!, aqui designados).

= Pisonia subcapitata Huber, Bol. Mus. Paraense Emilio Goeldi, sér. Bot. 5(2): 349. 1909. Tipo: Brasil, Pará: "Almeirim, campo baixo", 14.XII.1902, fl. est., $A$. Ducke 3052 (lectótipo MG, n.v.: isolectótipo RB!, aqui designado). Syn. nov.

= Pisonia subcapitata var. laxiuscula Huber, Bol. Mus. Paraense Emilio Goeldi, sér. Bot. 5(2): 349. 1909. Tipo: Brasil, Pará: Rio de Faro, Vista Alegre, 6.IX.1907, fl. est., A. Ducke 8939 (holótipo MG n.v.; isótipo RB!). Syn. nov.

= Pisonia stellulata Huber, Bol. Mus. Paraense Emilio Goeldi, sér. Bot. 5(2): 350. 1909. Tipo: Brasil, Pará: "Óbidos, capueira", 20.XII.1903, A. Ducke 4855 (holótipo MG n.v.; isótipo RB!). Syn. nov.

= Neea glomeruliflora Heimerl, Notizbl. Bot. Gart. Mus. Berl. 6: 126. 1914. Tipo: Brasil, Amazonas, "ad oram meridionalem flum. Amazonum prope ostium flum. Solimoes", VI.1851, Spruce 1602 (lectótipo K!; isolectótipos BR!, P!, RB!, aqui designados). Syn. nov.

= Neea glomeruliflora var. coniungens Heimerl, Notizbl. Bot. Gart. Mus. Berl. 6: 127. 1914. Tipo: Brasil, Amazonas: "Jurua-emirim", VI.1901, Ule 5575 (lectótipo K!, aqui designado). Syn. nov.

= Neea sparsiflora Heimerl, Notizbl. Bot. Gart. Mus. Berl. 6: 129. 1914. Tipo: Brasil, Amazonas: "Juruamirim”, IX.1901, fl. pist., Ule 5855 (holótipo K!). Syn.nov.

Fig. 49

Nome vulgar: joão-mole (Rosa 1368, Pires 742, Cavalcante 134).

Arbustos a árvores, 1,0-25,0 m alt., caule 20,0$25,0 \mathrm{~cm}$ diâm., muito ramificado; ramos geralmente dicotômicos, retos, cilíndricos, lenhosos, não compressos quando secos, dicotômicos, muitas vezes com predominância de um ramo; ramos novos pubérulo-ferrugíneos a glabrescentes; entrenós 2,5$6,5 \mathrm{~cm}$ compr. Folhas com pecíolo 0,5-1,9 cm compr. Laminas $4,2-21,1 \times \quad 1,5-7,4 \mathrm{~cm}$, ovadas, ovadoelípticas, ovado-lanceoladas, a lanceoladas, base obtusa a aguda, atenuada, às vezes quase até a base do pecíolo, ápice agudo, acuminado a caudado; cauda até 2,5 cm compr., aguda curva a arredondada; verde escuras, ferrugíneo-pubérulas a geralmente glabrescentes, indumento adpresso; quando secas 


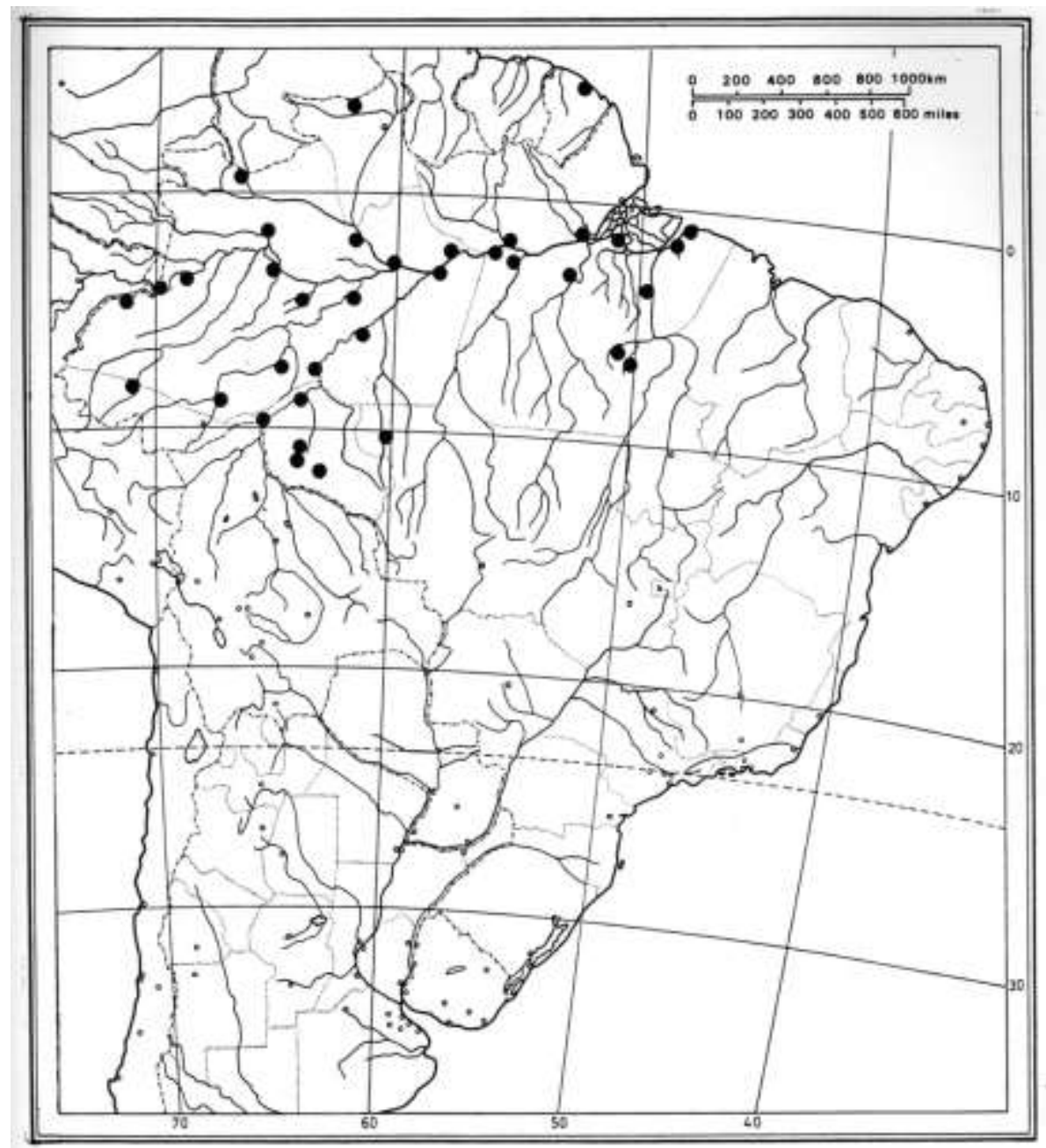

Fig. 48 - Distribuição geográfica de Neea oppositifolia.

cartáceas, as jovens membranáceas, face superior preta a verde-oliva pardacenta, face inferior marrom, frequentemente brilhantes na face superior e às vezes com aspecto envernizado, um pouco mais opacas embaixo; nervura mediana saliente embaixo, nervuras primárias pouco salientes embaixo, visíveis, várias, paralelas, apróximadas. Inflorescências 3,8-6,5 x 2,0$3,3 \mathrm{~cm}$, predominantemente axilares, raramente maiores que as folhas, comumente as pistiladas capiláceas, as jovens com aspecto estrelado, em geral ferrugíneas; pedúnculo 1,4-2,3 cm compr., ca. 0,4-1,0 $\mathrm{mm}$ espessura, esparsamente ferrugíneo-pubérulo; ramos primários em geral subopostos, ou um ramo alterno depois opostos, oblíquos, às vezes subverticilados a pouco aglomerados especialmente nas inflorescência pistiladas, ramos distais raramente pouco desenvolvidos; brácteas na base das címulas, raramente no meio dos ramos, semelhantes às bractéolas; bractéolas 0,3-0,8 x 0,3-0,5 mm, deltóides, agudas, ferrugíneas; botões estaminados 3,8-6,3 $\mathrm{x}$ 0,7-1,8 mm, oblongo-ovóides, aglomerados, pubéruloferrugíneos, esverdeados a castanhos; flores estaminadas $6,0-10,0 \times 1,2-3,0 \mathrm{~mm}$, tubulosas, oblongas a ligeiramente ovadas, ápice em geral não constrito, ferrugíneas, especialmente na base, verdeclaro a creme; lobos do cálice até $1,5 \mathrm{~mm}$ compr., dentiformes a oblongos, retorcidos ou reflexos quando secos; estames 6-9, até 4,5 $\mathrm{mm}$ compr.; botões pistilados $1,5-2,2 \times$ ca. $1,0 \mathrm{~mm}$, pouco ou não constrictos no meio; flores pistiladas 2,5-5,3 x 0,7-1,3 $\mathrm{mm}$, fauce até $1,8 \mathrm{~mm}$ larg., ferrugíneas, róseas; lobos do cálice eretos, retorcidos a pouco reflexos, estaminódios em geral 8; estigma agudo, pouco lacerado, foliáceo no ápice a tricomatoso, saliente até 0,8 mm. Infrutescências 3,4-5,2 x 2,4-3,5 cm; pedúnculo 1,1-2,5 cm compr.; bractéolas persistentes; antocarpos 9,0-12,0 x 3,2-5,0 mm, oblongo-elipsóides, pubérulos a glabros, amarelados a negros os maduros; cúpula 1,0-2,5 mm alt., ferrugínea, lobos fechados, às vezes estigma saliente até $0,5 \mathrm{~mm}$ entre os lobos da coroa.

Schmidt (1872) ao descrever Neea ovalifolia baseou-se em dois sintipos: Spruce s.n. "prope Mangos, Alto Amazonas" e Burchell 10011-5 do Pará. 


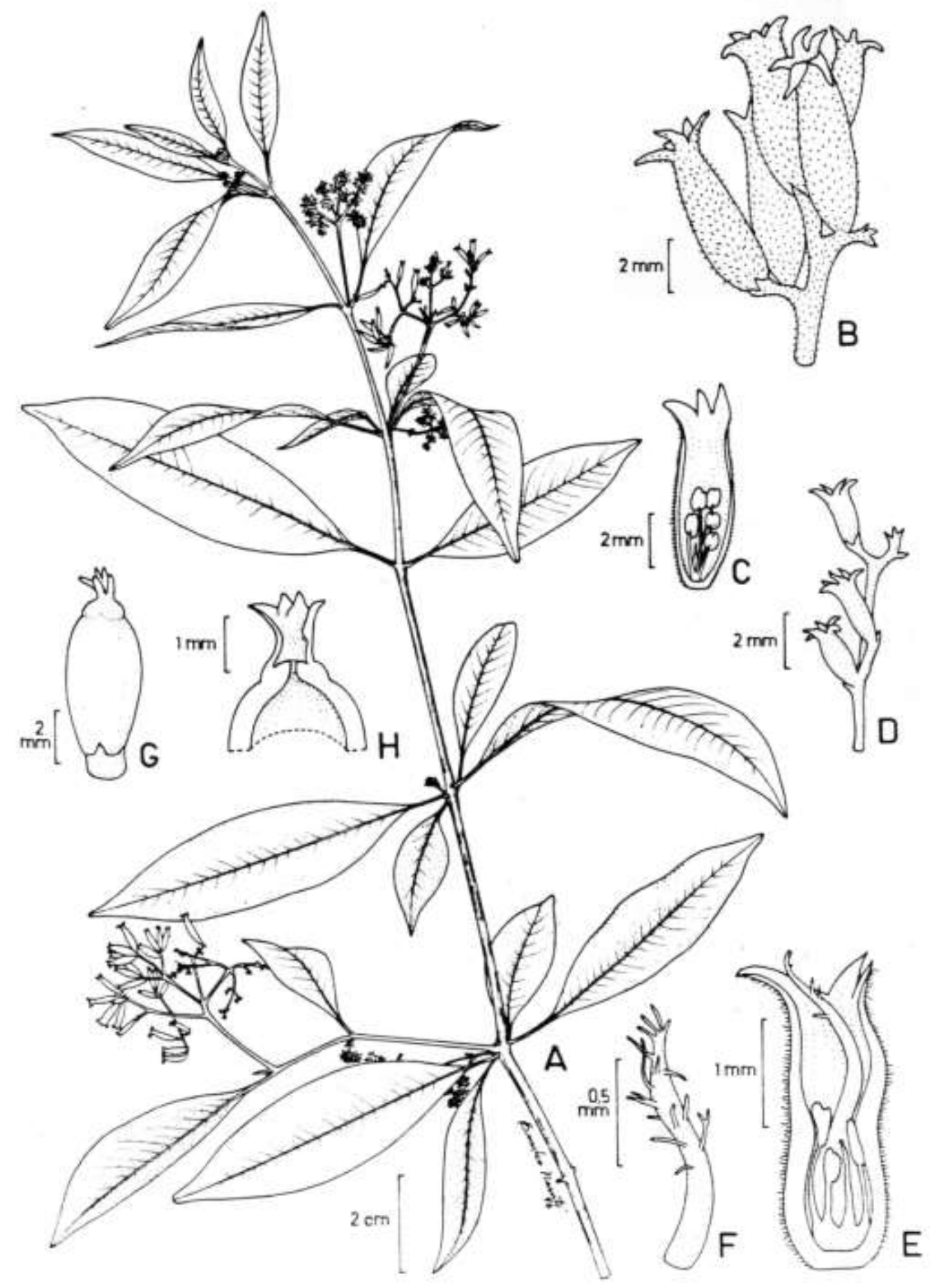

Fig. 49 - Neea ovalifolia: A. Ramo de planta estaminada com inflorescências jovens e adultas. B. Ramo terminal de inflorescência estaminada. C. Flor estaminada com o cálice em corte longitudinal. D. Ramo terminal de inflorescência pistilada. E. Flor pistilada com o cálice em corte longitudinal. F. Detalhe do estigma. G. Antocarpo. H. Esquema do ápice do antocarpo e em corte longitudinal. (A-C - G.T. Prance et al. 5892; D-F - L.O.A. Teixeira et al. 743; G-H - G.T. Prance et al. 15164). 
O autor descreve apenas as flores pistiladas e os frutos. Foram examinados vários espécimes coletados por Spruce, porém nenhum proveniente de Manaus e com flores pistiladas e frutos. No herbário $M$ consta como tipo desta espécie, o material Spruce 641 onde está anotado "Neea ovalifolia sp. n.", mas este material é um ramo estaminado proveniente do Pará, perto de Santarém. No herbário $\mathrm{K}$ há um material idêntico, anotado como tipo, com etiqueta similar, proveniente do mesmo local e mesmo tipo de letra do material de Munique, porém com número Spruce 879. Há ainda neste mesmo herbário uma outra exsicata, separada como tipo, manuscrita pelo próprio Spruce "879* Neea ovalifolia sp. n", mas também oriunda de Santarém, Pará e com flores estaminadas. Já no RB existe um material de Spruce proveniente de Manaus, contudo trata-se também de uma planta estaminada. O outro síntipo, Burchell 10011-5 é composto de espécimes com flores pistiladas e frutos e depositados em alguns herbários e concordando perfeitamente com a descrição da espécie, tendo sido nesse trabalho selecionado como lectótipo.

Neea ovalifolia foi descrita originalmente como inteiramente glabra, porém entre os materiais examinados há exemplares com folhas pilosoferrugíneas a glabras. Esta espécie caracteriza-se pelas folhas ovadas a lanceoladas, com muitas nervuras primárias paralelas e apróximadas entre si, pouco salientes mas visíveis, inflorescências axilares com pedúnculo curto, pouco aglomeradas a laxas e usualmente menores que as folhas, inflorescências jovens ferrugíneas e com aspecto mais ou menos estrelado, e flores tubulosas cilíndricas com ápice ligeiramente alargado mas não urceoladas.

Os protólogos de Pisonia subcapitata e $P$. stellulata, descritas por Huber (1909) citam os tipos no "Herbário Amazônico", cuja coleção atualmente deve estar incorporada ao herbário MG. O material-tipo examinado de $P$. stellulata mostra flores e inflorescências idênticas às do tipo de $N$. ovalifolia. As folhas são um pouco maiores que a média, mas apresentam as nervuras típicas da espécie. Heimerl (1914) já havia indicado $P$. stellulata como uma espécie a ser transferida para Neea, mas não formalizou a nova combinação.

Pisonia subcapitata var. laxiuscula Huber, apesar de possuir inflorescência laxa com até $3,5 \mathrm{~cm}$ de largura, e pedúnculo relativamente longo (cerca de $4,0 \mathrm{~cm}$ de comprimento), apresenta os demais caracteres florais de $N$. ovalifolia, não podendo ser separada desta. O material-tipo deste taxon é muito semelhante ao material-tipo de $N$. sparsiflora Heimerl, o qual também não difere significativamente de $N$. ovalifolia.

Deve ter havido um engano de Heimerl (1914) ao listar os materiais usados na sua descrição de $N$. glomeruliflora pois o autor menciona Spruce s.n. para o material do Amazonas, e Spruce 1602 para o material do Pará. Em todos materiais-tipo examinados do Amazonas com a indicação "ad oram meridionalem...." consta Spruce 1602. O lectótipo aqui designado (Spruce 1602 em K) foi escolhido por ser o mais representativo da descrição e incluir várias inflorescências em bom estado. Os materiais-tipo de $N$. glomeruliflora e de N. glomeruliflora var. coniungens mostram as inflorescências iguais às inflorescências características de $N$. ovalifolia, onde as flores jovens são aglomeradas em aspecto estrelado, enquanto as flores mais desenvolvidas são ligeiramente mais laxas e com ramificação oposta e aglomerada; porém em ambos casos as inflorescências são menores que as folhas.

Heimerl (1914) diferencia N. glomeruliflora e suas duas variedades, $N$. glomeruliflora var. coniungens e $N$. glomeruliflora var. latifolia (esta última sem tipo localizado até agora), pelos estames e tamanho do cálice. Para este autor, estes três táxons teriam 8 estames e cálice com até $1,0 \mathrm{~cm}$ de comprimento, enquanto $N$. ovalifolia teria 9-10 estames e cálice com $0,5 \mathrm{~mm}$ de comprimento. O autor deve ter visto poucos materiais de $N$. ovalifolia, pois entre os materiais estudados ocorrem flores com 6 a 9 estames e cálice com 6 a $10 \mathrm{~mm}$ de comprimento.

Embora nos herbários haja identificações que confundem $N$. ovalifolia com $N$. hermaphrodita, devido às folhas com formas semelhantes, esta última espécie pode ser diferenciada pelas inflorescências em geral terminais, flores estaminadas urceoladas, pilosidade em geral pardo-amarelada não ferrugínea e nervuras primárias não aproximadas.

Steyermark (1987) relacionou $N$. ovalifolia entre as espécies da Venezuela, mencionando as folhas com nervuras muito próximas, distanciadas por apenas 3-4 $\mathrm{mm}$.

Distribuição geográfica e habitats (Fig. 50): N. ovalifolia ocorre principalmente na região amazônica, com apenas um registro na Bahia, mostrando um padrão disjunto de distribuição exibido por outras espécies deste gênero, como $N$. hirsuta e $N$. floribunda. Esta espécie tem sido coletada mais frequentemente em capoeiras, campinarana, campinas abertas e em florestas de terra firme.

Material selecionado: Brasil. Acre: $9^{\circ} 20^{\prime} \mathrm{S}, 69^{\circ} 00^{\prime} \mathrm{W}$, Rio Macauha/Rio Yaco, B.A. Krukoff 5424, 11.VIII.1933, bot. est. (BM, K, M). Amapá: Serra do Navio, N.A. Rosa 1368, 15.XII.1976, estéril (MG). Amazonas: Manaus, J. Chagas s.n., 30.VII.1956, bot. est. (INPA 4004, RB); Rio Curicuriari, Rio Negro, G.T. Prance et 16047, 3.XI.1971, fr. (K, MG, R). Bahia: Itambé, R.L. Froes 20053, 4.XII.1942, bot. est. (IAC, IPA, K). Mato Grosso: Sinop, W. Thomas et al. 4037, 25.IX.1985, infl. jovem (INPA, NY, SPF). Pará: Belém-Brasília km 131, E. Oliveira 342, 13.I.1960, fr. (UB); sem localidade, Burchel 10011-5, 6.I.1830, fl. pist./fr. (BR, K, P, síntipo de N. ovalifolia). Rondônia: Santa Bárbara, L.O.A. Teixeira et al. 743, 25.V.1982, fl. pist. (MG).

Guiana. Akarai mountains, A.C. Smith 2913, 20.I.1938, fr. (K). bot. est. (M)
Venezuela. Orinoco, F.J. Breteler 4772, 22.XI.1965, 


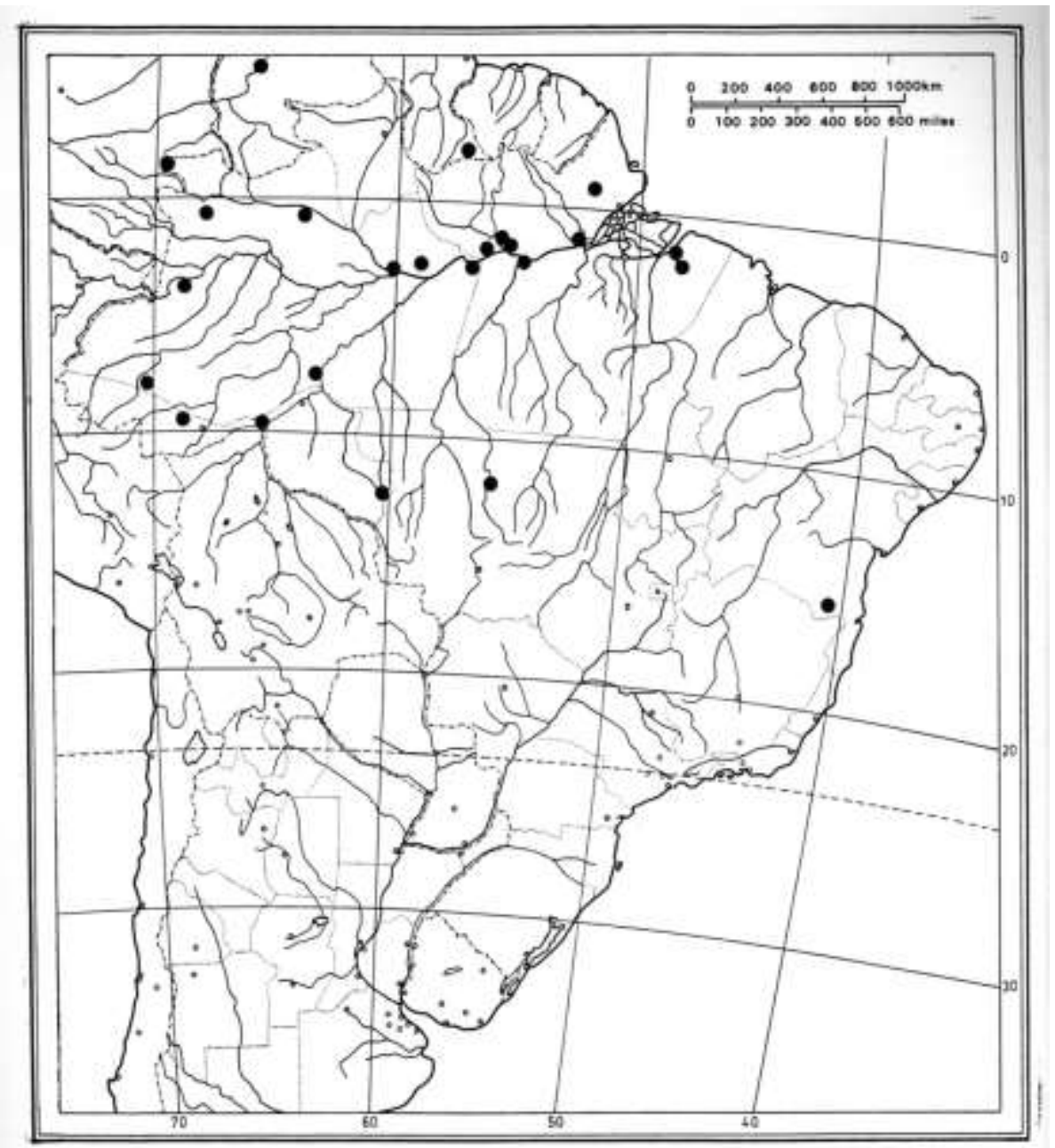

Fig. 50 - Distribuição geográfica de Neea ovalifolia.

2.11. Neea parviflora Poepp. \& Endl., Nov. gen. sp. pl. 2: 46. 1838. Tipo: Peru, "in sylvis prov. Maynas", Poeppig s.n. (segundo Standley 1937a) ou Poeppig 2372 (segundo Choisy 1849) (holótipo n.v.).

= Neea mollis Spruce ex J.A. Schmidt in Mart., F1. bras. 14(2): 367. 1872. Tipo: Brasil, "prope S. Gabriel da Cachoeira ad Rio Negro, prov. Alto Amazonas", $R$. Spruce 2327 (holótipo K!; isótipos BM!, BR!, P!, RB!). Syn. nov.

= Neea paraensis Huber, Bol. Mus. Paraense Emlio Goeldi, ser. Bot. 5(2): 351. 1909. Tipo: Brasil, "Alemquer, beira do campo de várzea", 1.I.1904, fl. pist., A. Ducke 4948 (holótipo MG n.v.; isótipo RB!). Syn. nov.

Fig. 51

Nome vulgar: yana-muco (G. Klug 1955; Standley 1937a)

Arbustos a árvores, 3,0-5,0 m alt., caule ca. 8,0 cm diâm.; ramos distais retos a pouco tortuosos, quebradiços, dicotômicos, glabros, córtex esbranquiçado, os novos hirsuto-tomentosos. Folhas com pecíolo 6-13 $\mathrm{mm}$ compr., usualmente pouco hirsuto. Laminas 5,2-20,4 x 2,3-6,4 cm, elípticas, ligeiramente obovadas, às vezes lanceoladas, base aguda a obtusa, assimétrica, ápice agudo a obtuso, raramente arredondado, acuminado a caudado, cauda às vezes ligeiramente curva, opacas, pouco ásperas, as novas róseas, quando secas enegrecidas; glabrescentes ou indumento hirsuto esparso, mais condensado nas nervuras, róseo, quando seco castanho escuro quase negro; tricomas até 3,0 mm compr., unisseriados, não ramificados. Inflorescências 2,1-2,8 x 2,2-2,4 cm, menores que as folhas, axilares, muito hirsutas; subsésseis ou pedúnculos até $1,8 \mathrm{~cm}$ compr., ca. 2,0 mm espessura, lenhoso; ramos opostos, lenhosos, curtos, em geral não ramificados; glomérulos de flores 1,5-2,0 cm diam., no ápice dos ramos primários, glomérulos estaminados mais laxos; brácteas 2,5-7,0 x 0,5-1,0 mm, lanceoladas, às vezes maiores que as flores, semelhantes entre si; bractéolas 1,0-4,0 x ca. 0,5 mm, lanceoladas, menores 


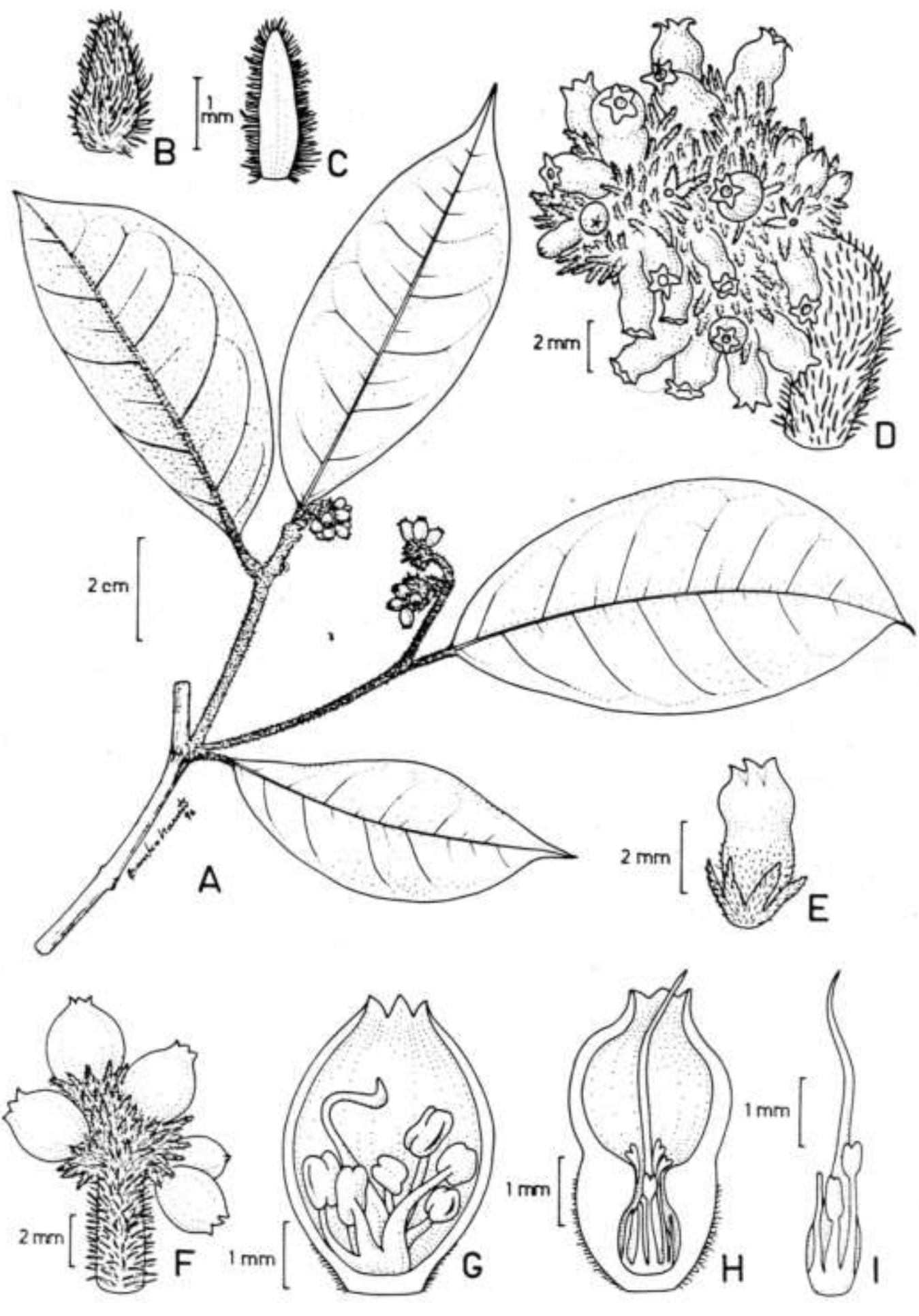

Fig. 51. Neea parviflora: A. Ramo de planta estaminada. B. Bráctea da inflorescência, vista dorsal. C. Bráctea da inflorescência, vista ventral. D. Ramo terminal de inflorescência pistilada. E. Flor pistilada com bractéolas. F. Ramo terminal de inflorescência estaminada. G. Flor estaminada com o cálice em corte longitudinal. $\mathrm{H}$. Flor pistilada com o cálice em corte longitudinal. I. Ovário e estaminódios. (A, F-G - A. Ducke s.n., RB 25638; B-E, H-I - A. Ducke s.n., RB 25639). 
que as flores, pouco desiguais, pretas a ferrugíneas quando secas; flores estaminadas 4,0-6,0 x 2,5-3,5 $\mathrm{mm}$, urceoladas, em cimeiras trímeras aglomeradas, vermelho-claras a esbranquiçadas, estames 6-8; flores pistiladas 4,0-7,0 x ca. $2,0 \mathrm{~mm}$, tubulosas, cilíndricas, estreitadas no meio ou pouco acima, constritas na fauce, verde-amareladas; lobos do cálice patentes, róseos, pilosas na região basal; estaminódios 7, unidos na base ou raro livres; estigma agudo, pouco papiloso, não lacerado, saliente até $0,6 \mathrm{~mm}$. Infrutescências ca. $2,5 \times$ ca. $3,0 \mathrm{~cm}$, pedúnculo ca. 1,5 cm compr.; antocarpos ca. $6,0 \times 2,0 \mathrm{~mm}$, aglomerados nos ramos distais da infrutescência, glabros; cúpula ca. 1,0 mm alt., ca. 1,0 mm larg

Os materiais estudados de $N$. parviflora conferem bem com a descrição do protólogo e também pela chave de identificação das Nyctaginaceae do Peru de Standley (1937a), que menciona como tipo da espécie um espécime coletado por Poeppig sem número. Entretanto, Choisy (1849) cita como tipo Poeppig 2372, que não foi localizado no herbário de Paris estando provavelmente no herbário de Madrid ou Viena. Foram estudados também materiais identificados por Standley, como, por exemplo, Kuhlmann 240 e Klug 1955.

Neea parviflora caracteriza-se pelo indumento hirsuto, pela inflorescência com pedúnculo lenhoso e curto e pelas flores aglomeradas no ápice dos ramos distais da inflorescência, também pouco lenhosos. $N$. hirsuta seria a espécie mais semelhante, pelo tipo de indumento e pelas flores também aglomeradas nos ápices dos ramos da inflorescência, mas, enquanto $N$. hirsuta possui pedúnculos delgados, flexíveis e bractéolas mais longas que as flores, $N$. parviflora apresenta pedúnculos lenhosos, rígidos, espessos e bractéolas mais curtas que as flores.

Os binômios Neea mollis e $N$. paraensis são aqui sinonimizados porque baseiam-se em espécimestipo idênticos aos demais materiais estudados.

Segundo Standley (1937a), na Colômbia esta espécie é chamada de "Yana-Muco" e suas folhas são mascadas pelos nativos tornando seus dentes pretos mas fortalecendo-os.

Distribuição geográfica e habitats (Fig. 38): N. parviflora distribui-se pela Colômbia, Peru e Brasil, onde foi encontrada apenas no Amazonas, Pará e Mato Grosso. Tem sido coletada principalmente em florestas de terra firme.

Material selecionado: Brasil. Amazonas: Borba, Bela Vista, B.A. Krukoff 5990, 4-6.IX.1934, fl. est. (BM, BR, K); Itacoatiara/Manaus, E. Oliveira 2990, 12.XI.1962, fl. est. (UB). Mato Grosso: Sinop, W. Thomas et al. 4015, 24.IX.1985, bot. est. (INPA, NY, SPF). Rondônia: Rio Jatuarana/Rio Machado, B.A. Krukoff 1658, XII.1931, fr. (K).

Colômbia. Putumayo, $00^{\circ} 54,76^{\circ} 10$, G. Klug 1955, III.1931, fl. est. (BR, IAC, P, RB, SP).

Peru. $71^{\circ} 55$ 'S, $11^{\circ} 40^{\prime} \mathrm{W}$, R.B. Foster et al. 11647 4.X.1986, fl. pist. (K); Loreto, Maynas, Y.M. Rimachi 8260, 10.IX.1987, infl. jovem (BR).
2.12. Neea pendulina Heimerl, Ost. Bot. Z. 56(10): 413. 1906. Tipo: Brasil, "in Brasilia australi, prov. St. Catharina, anno 1889, niederer Strauch am Waldrande bei Tubarão", E. Ule 1092 (lectótipo US n.v.; isolectótipos P!; HBG n.v., segundo Reitz 1970).

= Neea schwackeana Heimerl, Ost. Bot. Z. 56(12): 424. 1906. Tipo: Brasil, Santa Catarina, Joinville, "in silva virginea ad fluvium Itapoca, Schwacke 12991 (lectótipo P! aqui designado). Syn. nov.

Fig. 52

Arbustos a arvoretas, 1,0-6,0 $\mathrm{m}$ alt., ramos geralmente retos, dicotômicos, patentes, córtex cinza quando seco, ramos distais glabros, às vezes ferrugíneo-pubérulos, entrenós em geral 2 entre as ramificações, gemas ferrugíneas. Folhas com pecíolo 0,5-2,6 cm compr., ferrugíneo-pubérulos a glabrescente. Laminas 1,6-16,1 x 0,9-6,3 cm, opostas ou verticiladas, às vezes subopostas em ramos alongados, pares desiguais ou não, elípticas, elípticolanceoladas, oblongo-lanceoladas, às vezes ligeiramente elíptico-obovadas, as menores elípticas a orbiculares, base aguda curto-atenuada desigualmente no pecíolo, raramente obtusa ou arredondada as novas, ápice agudo ou obtuso, frequentemente cuspidado ou caudado, raramente curto-acuminado, cauda até $1,5 \mathrm{~cm}$ compr., às vezes curva, membranáceas firmes, concolores, margem pouco ou não revoluta, nervuras secundárias 6-10, retas, oblíquas, pouco salientes, face superior glabra, opaca a pouco nítida, face inferior pubérula esparsa a glabrascente, opaca; tricomas em geral ferrugíneos, mais condensados na nervura mediana. Inflorescências 4,0-8,5 x 2,5-6,0 cm, terminais nas bifurcações, raro axilares, eretas ou geralmente pêndulas; pedúnculos 2,2-7,2 cm compr., ca. 0,5 mm espessura, verde-avermelhados a róseos, ramificados em geral verticiladamente, raro subverticiladamente, pouco pubérulos especialmente nas junções dos ramos; ramos da inflorescência até $1,0 \mathrm{~mm}$ diam., comumente mais espessos que o pedúnculo; cimeiras terminais usualmente trifloras, ramos laterais das cimeiras as vezes desenvolvidos até $2,5 \mathrm{~mm}$ compr.; brácteas até $2 \times$ ca. $0,5 \mathrm{~mm}$, apenas nos ramos distais, lineares a deltóides, ciliadas; bractéolas até 1,5 $\mathrm{mm}$ compr., na base das flores, deltóide-lanceoladas, em geral pubérulas, pouco ciliadas, reflexas, decíduas na frutificação. Flores verde-amareladas ou avermelhadas a rosa-claras; botões elipsóides, ápice obtuso a arredondado, raramente agudo, acuminado flores estaminadas 4,0-10,0 x 2,0-4,5 mm, fauce até 2 $\mathrm{mm}$ larg., elipsóide-urceoladas a ligeiramente cilíndricas, pubérulas especialmente na base a glabrescentes; lobos do cálice denteados, reflexos na antese; estames 5, raro 7, pouco unidos na base; pistilódio presente, estigma rudimentar obtuso, truncado; flores pistiladas 3,0-4,0 x 1,0-2,0 mm, cilíndrico-urceoladas, contraídas pouco acima da base; e no ápice, usualmente glabras; estaminódios 56; ovário elipsóide, estilete espessado, atenuado em 


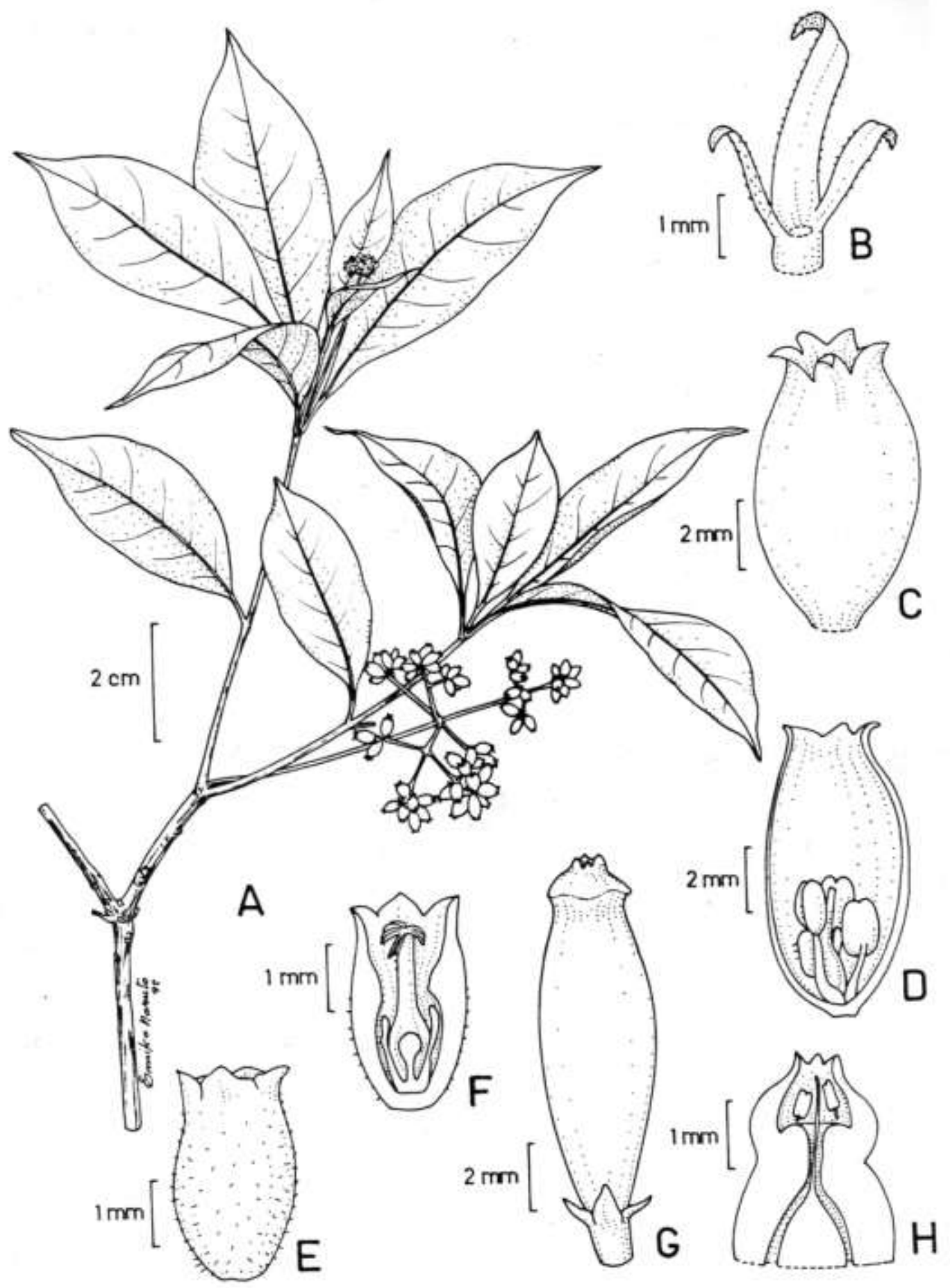

Fig. 52 - Neea pendulina: A. Ramo de planta estaminada. B. Bráctea e bractéolas. C. Flor estaminada. D. Flor estaminada com o cálice em corte longitudinal. E. Flor pistilada. F. Flor pistilada com o cálice em corte longitudinal. G. Antocarpo. H. Ápice do antocarpo em corte longitudinal. (A - R. Klein 2284; B-D - G. Hatschbach \& E. Moreira 6631; E-F - Y.S. Kuniyoshi et al. 5569; G$\mathrm{H}$ - Klein \& Bresolin 10644). 
estigma agudo pouco fimbriado lateralmente. Infrutescências $6,0-13,0 \times$ ca. $5,0 \mathrm{~cm}$, pêndulas; pedúnculo até $11,8 \mathrm{~cm}$ compr., não ou pouco espessado; ramos até $1,2 \mathrm{~mm}$ espessura, pouco mais espessados que o pedúnculo; antocarpos 6,0-10,0 x 4,0-6,0 mm elipsóides, pubérulos a geralmente glabros, vináceos a pretos; cúpula apical até $1 \mathrm{~mm}$ alt., geralmente compressa, cor fechada; embrião não analisado.

Neea pendulina distingue-se das demais espécies do gênero pelas folhas elípticas ou lanceoladas em geral concolores, e pela inflorescência com ramificação verticilada, assemelhando-se neste caráter a algumas espécies de Guapira.

Neea schwackeana foi descrita por Heimerl (1906c), baseando-se em seis sintipos coletados por Ule e Schwacke em Santa Catarina. Nesse trabalho é proposto como lectótipo o material de Schwacke 12991. Segundo o autor, N. schwackeana seria próxima de $N$. selloiana Heimerl, pela inflorescência umbelada, mas sem mencionar $N$. pendulina, também descrita com esse tipo de inflorescência. Porém, um dos síntipos de N. selloiana, Spruce 4196, compõe-se de três exsicatas com inflorescência dicotômica e não umbelada e nesse trabalho está sendo sinonimizada sob N. hermaphrodita S. Moore.

Reitz (1970) menciona algumas diferenças entre $N$. pendulina e $N$. schwackeana, que seriam: forma das folhas (lanceoladas versus elípticolanceoladas), tamanho das folhas $(4,0-5,5 \times 1,3-1,5$ $\mathrm{cm}$ versus 7,0-14,0 x 3,0-6,0 cm), e orientação da inflorescência (bem pêndula versus quase ereta). Quanto à forma e tamanho das folhas, a análise de grande número de espécimes não permite a separação em duas espécies. Também a orientação da inflorescência é variável, chamando a atenção que o próprio desenho de $N$. pendulina (Reitz 1970, pág. 25) mostra uma inflorescência ereta e uma pêndula, a foto de N. schwackeana (Reitz 1970, pág. 21) exibe inflorescência pêndula, assim como uma ilustração anterior de $N$. pendulina (Reitz 1960). Por estes motivos o binômio $N$. schwackeana está sendo sinonimizado sob $N$. pendulina, nome que tem preferência por ter sido publicado dois meses antes que o outro.

O estudo polínico de $N$. pendulina e $N$. schwackeana realizado por Barth \& Barbosa (1972) apoia a sinonimização aqui proposta, pois segundo as autoras ambos táxons são muito semelhantes, podendo ser separados apenas pelas dimensões do lúmen dos retículos, que são maiores em $N$. schwackeana.

Distribuição geográfica e habitats (Fig. 53): Trata-se de uma espécie típica da Mata Atlântica pluvial, com ocorrência restrita ao Rio de Janeiro, São Paulo, Paraná e Santa Catarina. Floresce de setembro a março e frutifica de dezembro a abril.

Material selecionado: Brasil. Paraná: Antonina, G. Hatschbach \& E.M. Zardini 40947, 10.XI.1978, fl. est. (MBM);
Morretes, O.S. Ribas et al. 363, 1.IX.1991, fl. est. (MBM, SPF). Rio de Janeiro: Magé, P. Occhioni 8358, III.1978, infl. jovem (MBM). Santa Catarina: Florianópolis, $R$. Klein e A. Bresolin 8055,19.XII.1968, fl. est. (ICN, PACA); Blumenau, "Strauch im Walde der Velha bei Blumenau", E. Ule 957 (um dos sintipo de N. schwackeana P!). São Paulo: Iguape, P.H. Davis et al. D-60532, 6.IX.1976, fl. est. (SP, UEC).

2.13. Neea theifera Oerst., Overs. K. danske Vidensk. Selsk. Forh.: 9, pl. 1. 1863. Tipo: não citado, provavelmente Reinhardt s.n. (n.v.) ou Lund s.n. (n.v.).

= Pisonia caparrosa Netto, Ann. Sci. nat. ser. 5, Bot. 5: 82. 1866. Tipo: Brasil, Goiás, Weddell 2851 (lectótipo, P! aqui designado).

Neea pectinata Rizzini, Leandra 5(6): 34. 1975. Tipo: Brasil, "in cerrato, Minas Gerais, ad Imbiruçu", 20.III.1959, E.P. Heringer 6823 (holótipo, RB!). Syn. nov.

Fig. 54

Nomes vulgares: caparrosa-do-campo (Netto 1866a); caparrosa (Heimerl 1891).

Arbustos a arvoretas, 0,3-4,0 m alt., caules originando-se em xilopódios quando jovens, ramos adultos geralmente tortuosos, lenhosos, córtex fissurado, ramos finais retos, carnosos, verde-glaucos, gemas ferrugíneas. Folhas com pecíolo $0-3,0 \mathrm{~mm}$ compr., ca. 3,0 mm espessura. Laminas 4,1-12,8 x 1,8-7,2 cm, sésseis a subsésseis, opostas a subopostas, às vezes alternas em ramos longos, pares pouco a não desiguais, os pares inferiores frequentemente menores, oblongas, oblongo-elípticas, elípticas, ovadas, as basais às vezes ligeiramente obovadas, as menores orbiculares, base cordada a arredondada, em geral inequiláteras, ápice arredondado, emarginado, obtuso, raramente agudo, cartáceas a subcoriáceas, carnosas, nervuras não salientes, verde-glaucas, cera presente nas duas faces quando jovens, depois brilhantes, glabras; quando secas, pretas a cinza, cartáceas flexíveis ou em geral rígidas, nervuras secundárias 5-10 pouco salientes. Inflorescências 2,1-4,5 x 3,2-6,3 cm, terminais, raramente axilares, em panículas de cimeiras; pedúnculo ereto, 1,2-7,9 cm compr., até 3,0 $\mathrm{mm}$ espessura, ferrugíneo-pubérulo no alto a glabro; ramos inferiores em geral subopostos ou raramente alternos ou ainda mais raramente verticilados, ramos distais racemosos, contraídos; brácteas até $2,5 \times$ ca. $1,5 \mathrm{~mm}$, na base dos ramos, às vezes ligeiramente foliáceas até 4,0 × 3,0 mm; bractéolas até 2,0 x ca. 1,0 $\mathrm{mm}$, na base das flores 2-3, usualmente deltóides carnosas, ferrugíneo-pubérulas a glabras, às vezes pouco ciliadas, persistentes após a dispersão dos antocarpos. Flores 4-6 meras, sésseis, botões de ápice agudo a obtuso; flores estaminadas 3,7-8,0 x 2,0-4,0 mm, globosas, ovóides, elipsóides ou urceoladas, glabras, verde-amareladas a rosadas de ápice rosa-claro a vináceo, lobos eretos a pouco reflexos na antese; estames 7-9, filetes cilíndricos, tecas usualmente desiguais, rimas longitudinais 


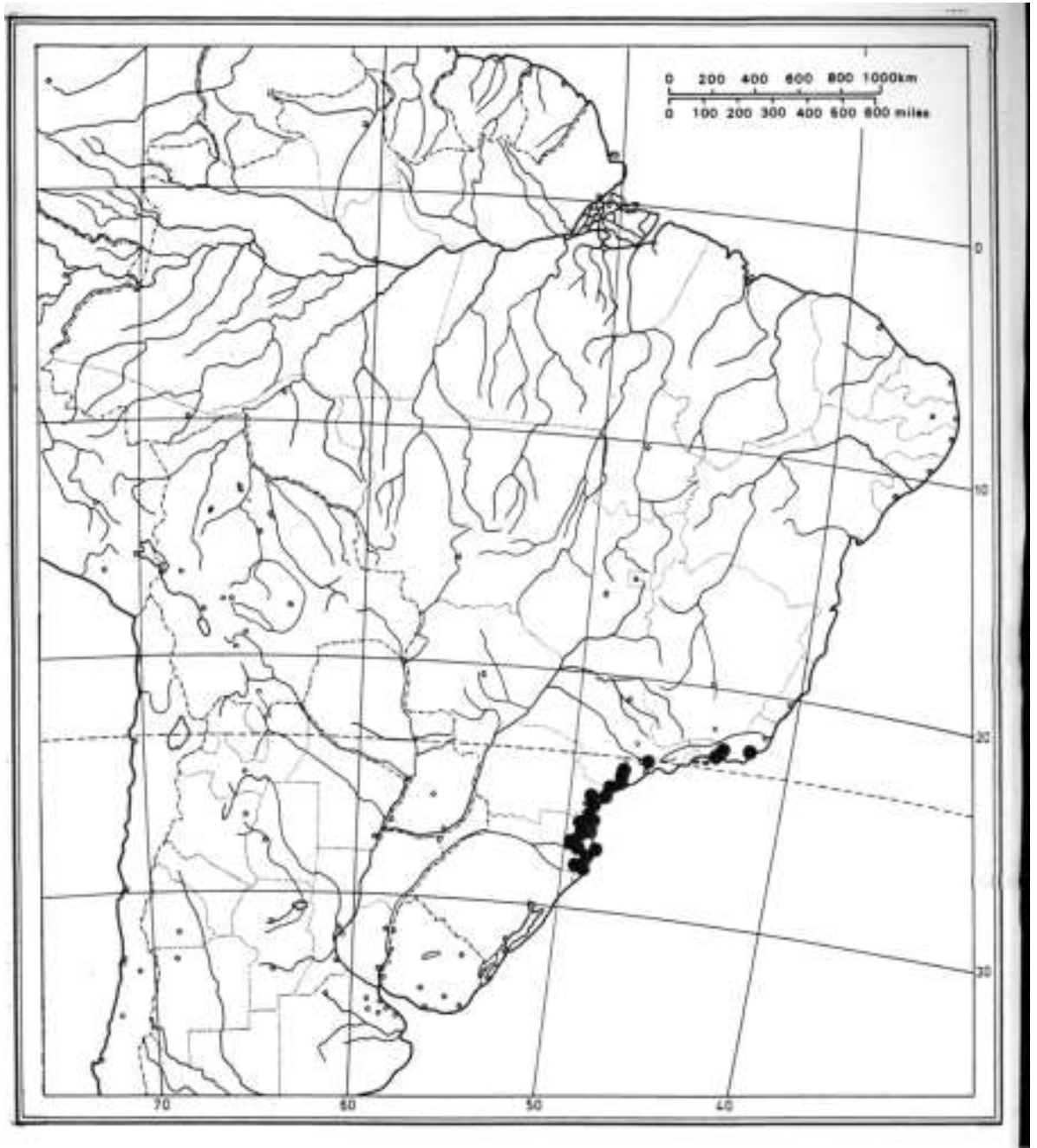

Fig. 53 - Distribuição geográfica de Neea pendulina.

laterais; pistilódio presente, estigma não desenvolvido, agudo, reto, incluso; flores pistiladas 3,5-5,0 x 2,0-3,0 $\mathrm{mm}$, obovóides a cilíndrico-clavadas, contraídas na região mediana, verde-rosadas de ápice avermelhado, glabras, cálice mais espessado internamente na região mediana; estaminódios 6-8, unidos na base, rudimentos de antera planos; ovário globoso ou elipsóide, estilete cônico-cilíndrico, ápice estigmatoso unilateralmente; estigma linear, agudo, papiloso ou pouco fimbriado na base, ápice ligeiramente saliente. Infrutescências 3,0-6,5 x 4,0-6,5 cm, ramos em geral não a pouco alongados, espessados, avermelhados; antocarpos elipsóides, raramente globosos, 7,0-16,0 x 4,0-7,0 mm, lisos, brilhantes, os imaturos verdeamarelados, os maduros róseos a vináceo-escuros, cúpula apical hemisférica, até $2 \mathrm{~mm}$ diam.; fruto membranáceo, estilete e estigmas persistentes; embrião reto, radícula ligeiramente curva, perisperma gelatinoso.
O protólogo de Neea theifera não inclui citação de espécime-tipo, contudo a descrição refere-se ao hábito arbustivo mencionando "teste $\mathrm{cl}$. Reinhardtio". Posteriormente Oersted (1866, 1869) citou Pisonia caparrosa Netto como sinônimo desta espécie, e indicou que um espécime seco do Brasil, remetido por Lund, teria estado à sua disposição na época da descrição original; contudo não há evidência de que qualquer material de Lund tenha sido utilizado na descrição de $P$. caparrosa por Netto. No herbário BM há um exemplar de $N$. theifera, coletado no Brasil por Lund s.n., doado pelo herbário do Museu Botânico Hauniensis, em cuja etiqueta consta "mis. Lund, Neea theifera Oerst.", isto é, remetido por Lund. A maior parte dos materiais ora examinados concorda exatamente com a excelente ilustração de Oersted (1863). A sinonimização de $P$. caparrosa em $N$. theifera já foi aceita também por Schmidt (1872), Heimerl (1891) e também nesse 


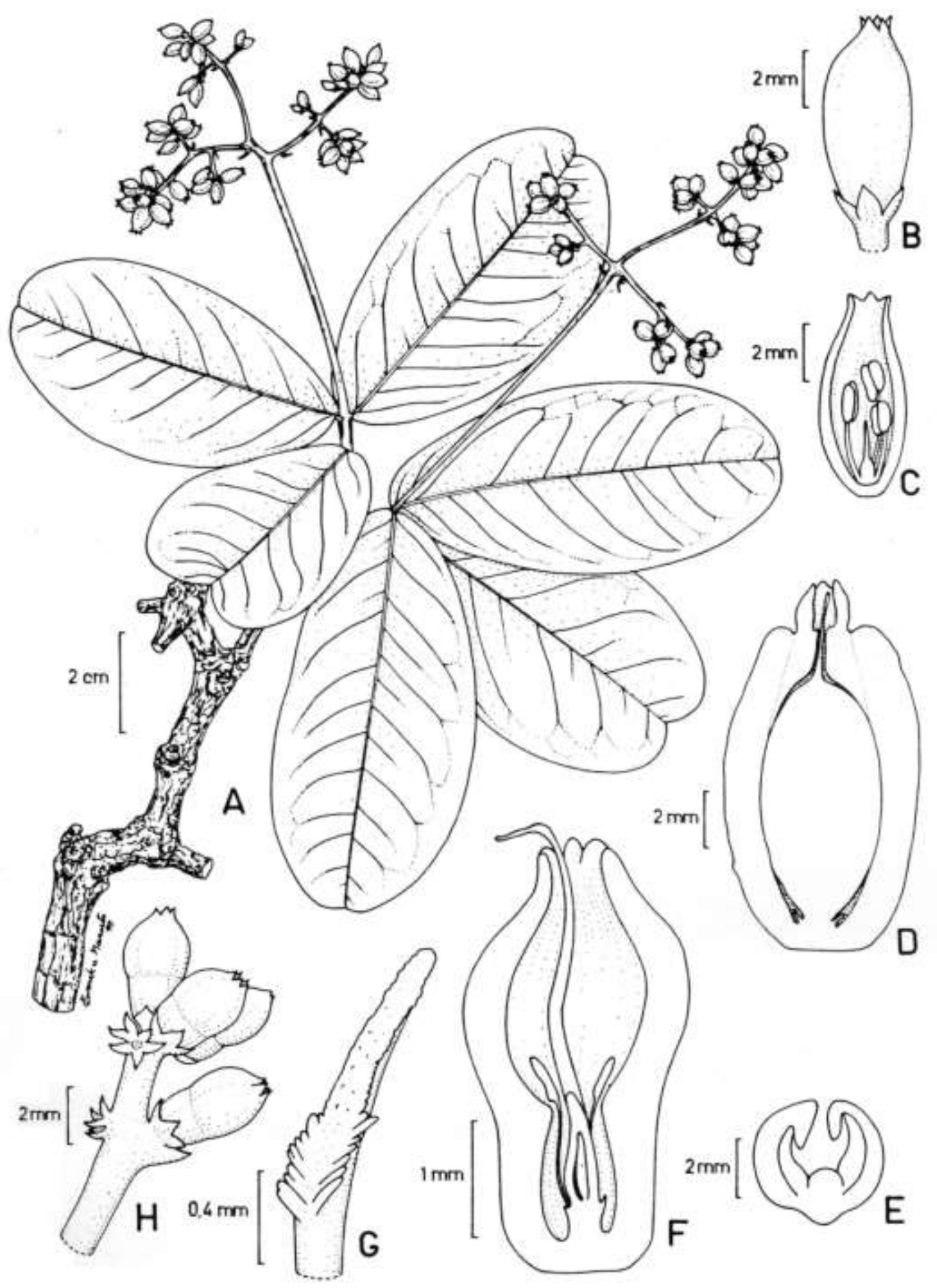

Fig. 54. Neea theifera: A. Ramo de planta estaminada. B. Flor estaminada. C. Flor estaminada em corte longitudinal. D. Antocarpo em corte longitudinal. E. Embrião em corte transversal. F. Flor pistilada em corte longitudinal. G. Detalhe do estigma. H. Ramo terminal de inflorescência pistilada. (A - C. Mauri 259; B-C - I. Cordeiro et al. CFSC 6643; D-E - I. Cordeiro et al. CFSC 6824; F-H - J.R. Pirani et al. CFSC 6675). 
trabalho, especialmente a partir da análise do lectótipo Weddell 2851, único dos quatro síntipos depositados em $\mathrm{P}$ que foi localizado. A descrição e a diagnose mencionam estames inclusos, caráter típico de Neea, e a excelente ilustração constante no protólogo mostra flores pistiladas e frutos, e não deixa dúvidas da identidade de $P$. caparrosa com $N$. theifera. Também, alguns sintipos citados por Netto (1866a), mostram confusão na numeração: é citado Saint-Hilaire 66, mas provavelmente refere-se ao número 166, pois a numeração deste coletor em sua viagem de 1816 a 1821 pelo Brasil, pelo menos em relação às Nyctaginaceae, inicia-se em 151 e prossegue até 1071, tendo sido localizado em $R$ uma duplicata, com o número 166. A coleção Weddell 2851 é citada como 1851 , certamente um erro pois a única amostra de $N$. theifera depositada no herbário $\mathrm{P}$ é coletada por Weddell 2851. Ainda no herbário $R$ há o material $L$. Netto 27, coletado em 1862 em Minas Gerais, que talvez corresponda ao espécime Netto 278 citado no protólogo.

Segundo Oersted (1869), N. theifera seria próxima de $N$. oppositifolia, contudo esta espécie tem folhas pecioladas de base aguda e ápice arredondado longo-acuminado. $N$. theifera parece ser mais próxima de $N$. duckei, que também tem folhas sésseis de base cordada, mas apresenta ápice agudo. Além disso, enquanto $N$. duckei ocorre apenas em florestas amazônicas, $N$. theifera predomina nos cerrados do Brasil Central. Vegetativamente, $N$. theifera assemelha-se a Guapira campestris, pelas folhas sésseis de base cordada.

Segundo Rizzini (1975), N. pectinata diferenciase de $N$. theifera pelas folhas coriáceas, bractéolas bem desenvolvidas e pectinato-pilosas, e perigônio mais longo. $\mathrm{O}$ estudo dos materiais-tipo de $N$. pectinata Rizz.: holótipo Heringer 6823 e parátipo Heringer 9092/1246, coletados em Brasília e depositados em RB, mostraram que as folhas são coriáceas como em $N$. theifera, e as bractéolas apesar de serem sempre ciliadas, podem ser ciladas também em alguns espécimes de $N$. theifera. Quanto ao perigônio em $N$. pectinata com $9 \mathrm{~mm}$ de comprimento, ser considerado mais longo, é devido ao fato desses exemplares estarem em início de frutificação, porém foram observadas algumas flores pistiladas ainda em fase de antese com cerca de $4 \mathrm{~mm}$ de comprimento, dentro da variação da espécie $N$. theifera. Pelo exposto propomos a sinonimização de Neea pectinata em $N$. theifera.

Segundo Netto (1866a) as folhas dessa espécie fornecem pigmento negro usado em tinturarias de Minas Gerais, para tingir tecidos de algodão. Oersted (1869) refere que as folhas de $N$. theifera contêm teína, ao passo que Schmidt (1872) afirma que elas têm pequena quantidade de cafeína; já Heimerl (1934) sustenta que as folhas servem para chá mas não contêm teína.

Beiguelman (1962) relata como caráter xeromorfo de $N$. theifera a presença de fibras do periciclo ramificadas no interior do mesofilo, mas não comenta a presença de cera na cutícula, previamente mencionada por Heimerl (1934).

Faria (1994) mostrou que as flores de $N$. theifera produzem néctar como recurso atrativo de insetos. Segundo Salgado-Laboriau et al. (1969), o pólen é oblato-esferoidal, 3-colpado, com colpos curtos e largos e sexina reticulada.

Distribuição geográfica e habitats (Fig. 55): N. theifera ocorre predominantemente em regiões de cerrado do Brasil e Bolívia. A florada se concentra entre agosto e dezembro, e a frutificação de outubro a janeiro. Novas floradas ocasionais podem ocorrer de fevereiro a abril.

Material selecionado: Brasil. Bahia: Barreiras, L.P. Queiroz et al. 2080, 2.XI.1987, fl. pist. (HRB, HUEFS, SPF). Distrito Federal: Brasília, E.P. Heringer 15608, 4.XI.1973, fr. (IBGE, MBM, SP, UEC). Goiás: Alto Paraiso de Goiás, Chapada dos Veadeiros, P.P. Furtado R.C. Mendonca 330, 6.XII.1988, fr. (IBGE). Maranhão: Carolina, J. Jangoux et al. 1758, 1.XII.1981, fl. est. (MG). Mato Grosso: Xavantina, D. Philcox et al. 3012, 14.XI.1967, fl. est. (K, P, RB, UB). Mato Grosso do Sul: Selvíria, O. Tiritan et al. 308, 29.XI. 1990, fl. est. (ISA, HRCB). Minas Gerais: Buritizeiro, J.E.M. Brazão 261, 18.XI.1981, fr. (HRB); Santana do Riacho, I. Cordeiro et al. CFSC 6643, 12.X.1980, fl. est. (K, SPF); sem localidade, A. Saint-Hilaire 166, 1816/1818, fr. (R); L. Netto 27, 1862, infl. jovem, ambos espécimes provavelmente síntipos de $N$. caparrosa. São Paulo: Mogi-Guaçu, W. Mantovani 1189, 16.X.1980, fl. pist. (SP, UEC). Tocantins: Taguatinga, R.C. Mendonça et al. 1974, 6.XII.1991, fl. pist. (SP).

Bolívia. Santa Cruz, R.B. Foster et al. 13762, 10.XI.1991, bot. est. (F, K).

2.14. Neea uleana (Heimerl) Furlan comb.nov. $\equiv$ Pisonia uleana Heimerl, Bot. Jb. 42: 80. 1909. 三 Guapira uleana (Heimerl) Lundell, Wrightia 4(2): 84. 1968. Tipo: "Brasília, Yurua Miry, Estado de Amazonas, aug.1901", Ule, Herbarium Brasiliense $n$. 5704 a (lectótipo K!).

Fig. 56

Arbustos a arvoretas, 3,0-6,0 m alt.; ramificação dicotômica com predominância de um dos ramos, ramos terminais retos, pouco lenhosos, ligeiramente fistulosos, hírtulos; quando secos compressos, não enegrecidos; entrenós 4,5-13,0 mm compr., muito constrictos logo acima dos nós não espessados; gemas pilosas, não ferrugíneas. Folhas com pecíolo 2,0-9,0 mm compr., os novos pouco ciliados lateralmente; tricomas unisseriados, não ramificados, amarelados. Folhas 5,5-12,5 x 3,0-7,2 $\mathrm{cm}$, ovadas, ovado-elípticas a elípticas, base obtusa a cordada, atenuada, ápice agudo, curto-acuminado, membranáceas, opostas, distanciadas, glabras ou folhas novas com margens esparsamente ciliadas próximo do pecíolo; quando secas marrons, pouco discolores, mais claras na face inferior, nervura mediana saliente e compressa na face inferior. Inflorescências terminais, pêndulas, laxas, indumento hírtulo, mais condensado nas articulações; pedúnculo 5,5-12,0 cm compr., flexível; ramos primários opostos, 


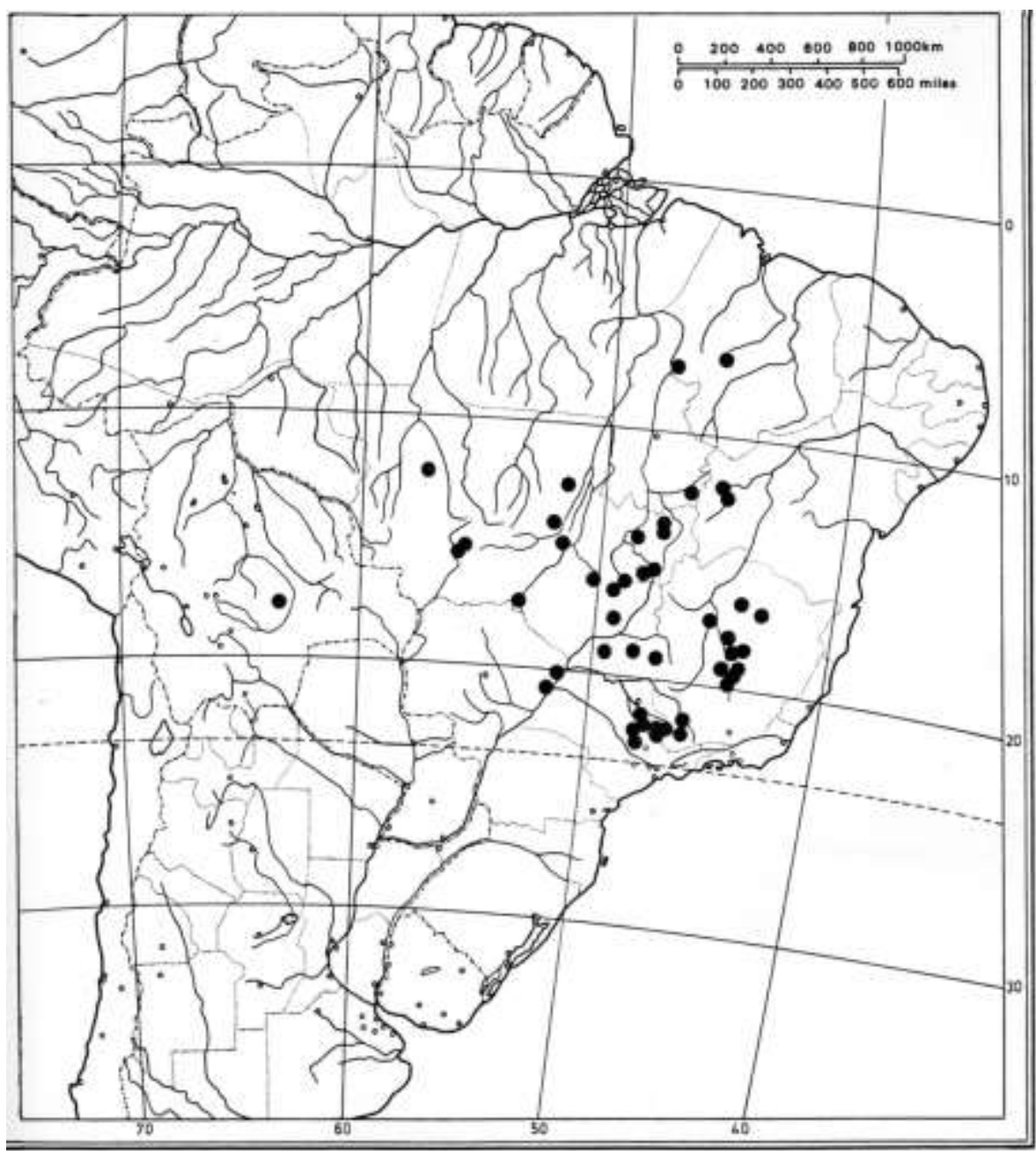

Fig. 55 - Distribuição geográfica de Neea theifera.

pouco patentes, os secundários dicotômicos; ramos distais ca. $0,5 \mathrm{~mm}$ espessura, racemosos a espiciformes, oblíquos, indumento mais denso; brácteas ca. 9,0 x 1,5 mm, foliáceas, oblanceoladas, na base dos ramos secundários, hírtulas; bractéolas 1,5-3,0 x ca. 0,3 mm, lineares, pouco hírtulas; flores estaminadas não vistas; flores pistiladas 2,5-3,5 x 1,22,0 mm, tubuloso-campanuladas a obcônicas, glabrescentes, marrom-esverdeadas a verdeamareladas; lobos do cálice arredondados a truncados, denticulados no ápice; estigma laceradofranjado, não saliente. Infrutescências e antocarpos não vistos.

Neea uleana caracteriza-se pelo indumento hírtulo dos ramos, pecíolos e inflorescência, e especialmente pelas brácteas linear-assoveladas chegando ao meio do cálice ou até ultrapassando-o. A espécie é similar com $N$. hirsuta e $N$. laxa, pelas inflorescências pouco pêndulas e longo-pedunculadas e pelo tamanho das brácteas. Em N. hirsuta entretanto, as inflorescências possuem flores aglomeradas nas terminações dos ramos e as folhas são geralmente muito maiores, longo-pecioladas e muito hirsutas. Em N. laxa, as folhas são predominantemente oblongas, permanecem verdes quando secas, e as inflorescências são glabras, enquanto em $N$. uleana as folhas escurecem quando secas e as inflorescências são um pouco hírtulas.

Heimerl (1909) descreveu Pisonia uleana a partir de um exemplar coletado por Ule 5704a com flores pistiladas, sem indicação do herbário onde estava depositado. Foi localizado apenas um exemplar em K, selecionado como lectótipo. Posteriormente, a espécie foi transferida para Guapira por Lundell (1968). Consideramos que a espécie possui vários caracteres ocorrentes em Neea onde foi incluída nesse trabalho, e não nos outros dois gêneros, como estigma lacerado-franjado, incluso no cálice, lobos do cálice denticulados e ramos distais da inflorescência racemosos ou espiciformes. Não foram vistos os antocarpos nos materiais examinados mas, segundo a 


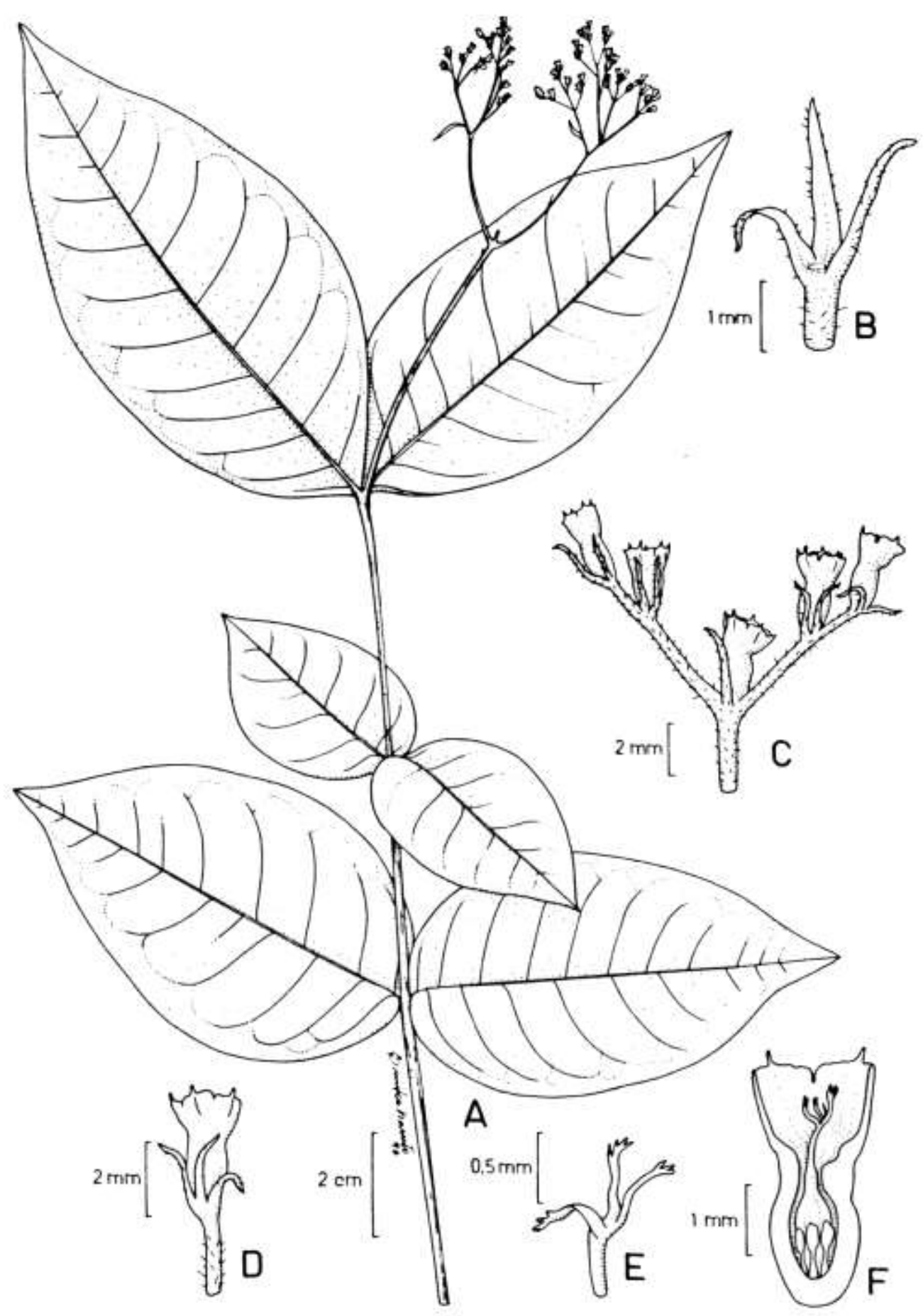

Fig. 56 - Neea uleana: A. Ramo de planta pistilada. B. Bráctea e bractéolas das flores. C. Ramo terminal da inflorescência pistilada. D. Flor pistilada. E. Detalhe do estigma. F. Flor pistilada com o cálice em corte longitudinal. (A-F - E. Ule 5703). 
descrição de Heimerl (1909), estes possuiam no ápice uma coroa ciatiforme mais alta que larga, outro carácter típico de Neea. Por outro lado, os estaminódios da flor pistiladas são pouco desenvolvidos e não atingem o espessamento interno da flor, caráter mais frequente em Guapira do que em Neea.

Embora as etiquetas dos espécimes mencionem arbustos e arvoretas, o tipo de ramificação dicotômica presente em ambos materiais examinados sugere que esta espécie seja ligeiramente escandente, pela predominância de um dos ramos que se alonga bastante. Em folhas novas e secas observam-se numerosas células portadoras de ráfides, que aparecem como pontos claros alongados.

Distribuição geográfica (Fig. 32): N. uleana foi coletada apenas no Rio Juruá-mirim que banha os estados do Acre e Amazonas.

Material examinado: Brasil. Acre: Juruá-mirim, E. Ule 5703, VIII.1901, fl. pist. (RB).

2.15. Neea verticillata Ruiz \& Pay., Syst. veg. fl. peruv. chil.: 90. 1798. Fl. peruv. 4: tab. 328. 1830. Tipo: Peru, "in Peruviae nemoribus prope Pozuzo vicum", Pavon s.n. (holótipo MA n.v.; isótipo P!).

Neea glaziovii Heimerl ex Glaz., Bull. Soc. Bot. Fr. 58, ser. 4, Mem., 3 f : 563. 1911. Tipo: Brasil, Rio de Janeiro, "pres de Tingua", out/nov., Glaziou 9559 (holótipo P!). Syn. nov.

Fig. 57

Arbustos, subarbustos ou árvores 0,9-5,0 m alt., raramente até $30 \mathrm{~m}$ alt., caule até $60 \mathrm{~cm}$, ramos distais pouco lenhosos, corticados, compressos quando secos. Folhas com pecíolo 1,3-3,0 cm compr., em geral curto, ca. 2,0 mm espessura, glabro. Folhas 17,1-39,1 x 6,1$9,7 \mathrm{~cm}$ opostas, verticiladas ou subverticiladas, em geral grandes, lanceoladas, oblanceoladas a oblongoobovadas, raramente oblongo-ovadas, base aguda atenuada, ápice agudo, às vezes obtuso, frequentemente longo-caudada, subcoriáceas, espessas, nervuras pouco ou não salientes, glabras; quando secas, marrons a verde pardas, raramente pretas. Inflorescências 4,4-6,6 cm diâm., terminais ou axilares, raramente em caulifloria em ramos terminais corticados, pouco laxa, ou flores aglomeradas no ápice, arroxeadas; pedúnculo 7,0-11,5 cm compr., em geral longo, flexível, ramificado dicotomicamente na porção distal, às vezes ramos alternos a opostos; brácteas até $4,0 \times$ ca. $1,0 \mathrm{~mm}$, linear-lanceoladas, na base dos ramos, ferrugíneo- pubérulas a glabrescentes; bractéolas ca. 1,0 mm compr., ápice agudo, pubérulas na base; botões estaminados ca. 4,0 ×2,0 mm, elipsóides, ápice arredondado, frequentemente curtoacuminados, arroxeados; flores estaminadas 5,0-8,0 x $3,5-5,0 \mathrm{~mm}$, urceoladas, fauce pouco estreitada, glabras a esparsamente pubérulas; estames 5-13; flores pistiladas não vistas. Infrutescências ca. $6,0 \mathrm{~cm}$ diâm., pedúnculo $11,4 \mathrm{~cm}$ compr., ramos distais até $2,0 \mathrm{~mm}$ espessura; antocarpos 14-17 x 3-4 mm, oblongos, glabros, arroxeados; cúpula 1,0-2,0 x ca. 1,0 mm, ereta, pouco aberta, espessamento saliente quando seca; estaminódios 5-7 unidos em taça, desenvolvidos até a cúpula, células com ráfides presentes na base dos estaminódios; estilete curto-franjado na região apical, incluso.

A etiqueta do isótipo de $N$. verticillata no herbário $\mathrm{P}$ não contém os dados da descrição original, porém a letra manuscrita é a mesma da etiqueta do isótipo de $N$. oppositifolia, as duas únicas espécies de Neea descritas por Ruiz \& Pavon (1798). Esse isótipo e a tábula 328 do protólogo permitem boa circunscrição do táxon.

O binômio Neea glaziovii tem diagnose muito breve, apenas "Arbuste, fl. rousses", mas o exame do holótipo mostrou que a planta apresenta folhas oblongo-obovadas, não muito escurecidas nem tão espessas quanto os espécimes de $N$. verticillata, mas possui flores estaminadas urceoladas, um dos caracteres típicos desta espécie, e por isso aqui se propõe a sinonimização.

Neea verticillata é similar em alguns caracteres com $N$. floribunda e vegetativamente com $N$. laxa. Porém, $N$. floribunda geralmente apresenta caulifloria, associada com folhas oblanceoladas de nervuras muito salientes, flores pouco abertas parecendo botões, e bractéolas muito curtas de ápice usualmente arredondado. Já $N$. laxa caracteriza-se pelas folhas esverdeadas a amareladas quando secas, frequentemente oblongas, mas possui flores estaminadas tubulosas e delgadas.

Distribuição geográfica (Fig. 58): N. verticillata ocorre na Amazônia peruana e brasileira e na Mata Atlântica, mostrando um padrão disjunto comum no gênero.

Material selecionado: Brasil. Alagoas: Fleixeiras, Andrade-Lima et al. 6, 8.VI.1981, fr. (SPF). Amazonas: Manaus, A. Araujo et al. 4, 10.X.1984, estéril (UTAM); Terra Preta, S.R. Hill et al. 12962, 5.VII.1983, bot. est. (UB). Bahia: Ilhéus, J.L. Hage et al. 1053, 7.VII.1981, fr. (CEPEC, SPF). Espírito Santo: Itaguaçu, A.C. Brade et al. 18074, 10.V.1946, fl. est. (RB). Minas Gerais: Caratinga, I.R. Andrade \& L.V. Costa 51, 6.VII.1987, fl. est. (BHCB). Pará: Belém, M. Kuhlmann et al. 396, 2.XI.1959, fr. (SP). Rio de Janeiro: Itatiaia, A.C. Brade 14618, 21.V.1935, fl. est. (RB). São Paulo, sem local, A. Saint-Hilaire 797, 1816/21, bot. est. (P). Peru. Maynas, Loreto, Y.M. Rimachi 4366, 30.III.1979, fr. (K). 


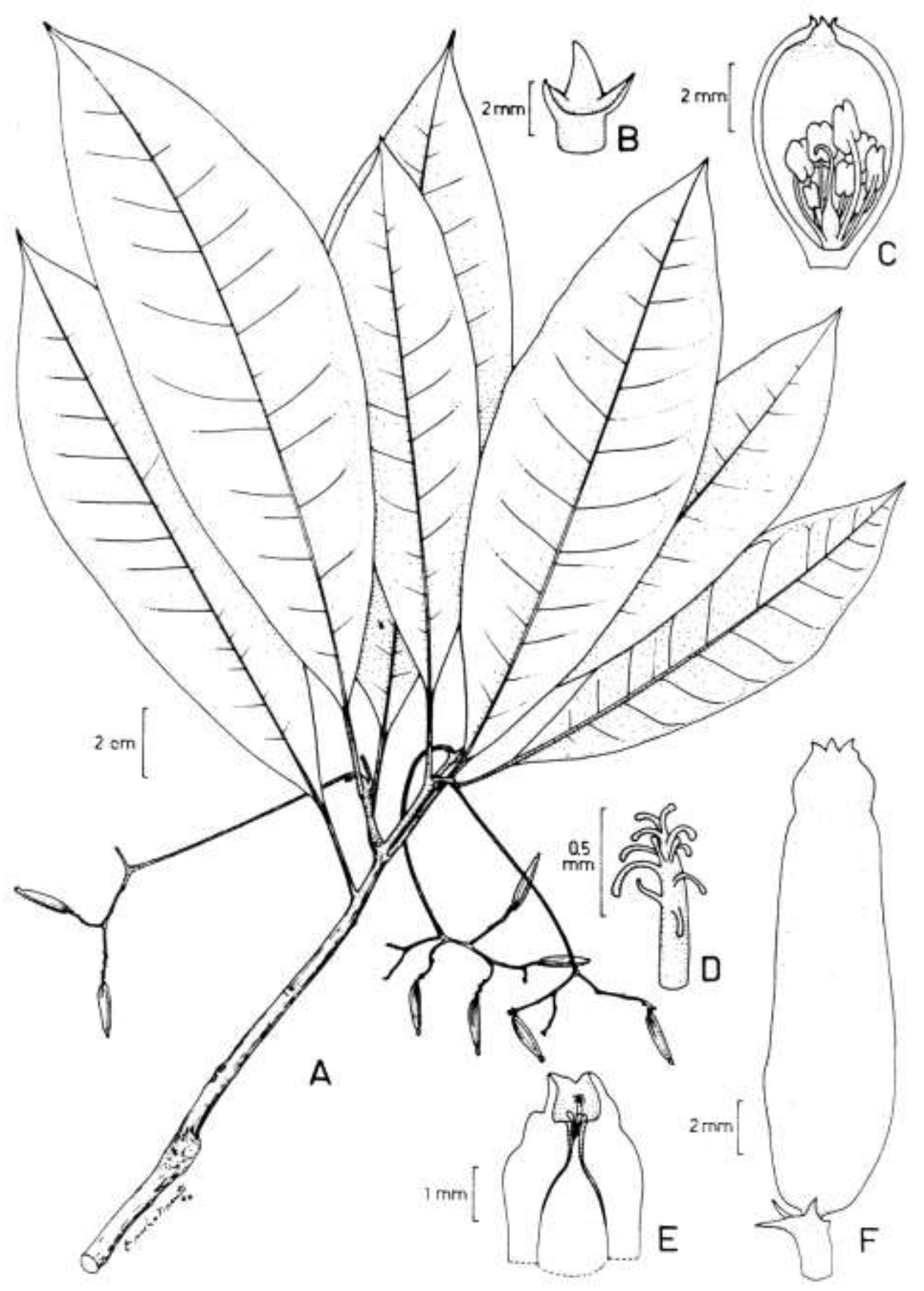

Fig. 57 - Neea verticillata: A. Ramo com infrutescências. B. Bráctea e bractéolas. C. Flor estaminada com o cálice em corte longitudinal. D. Estigma do fruto. E. Esquema do ápice do antocarpo em corte longitudinal. F. Antocarpo com bráctea e bractéolas. (A - M.B. Casari 198; B - M.A. Lopes \& P.M. Andrade 459; C - S.R. Hill 12962; D-F - P.M. Andrade \& M.A. Lopes 385). 


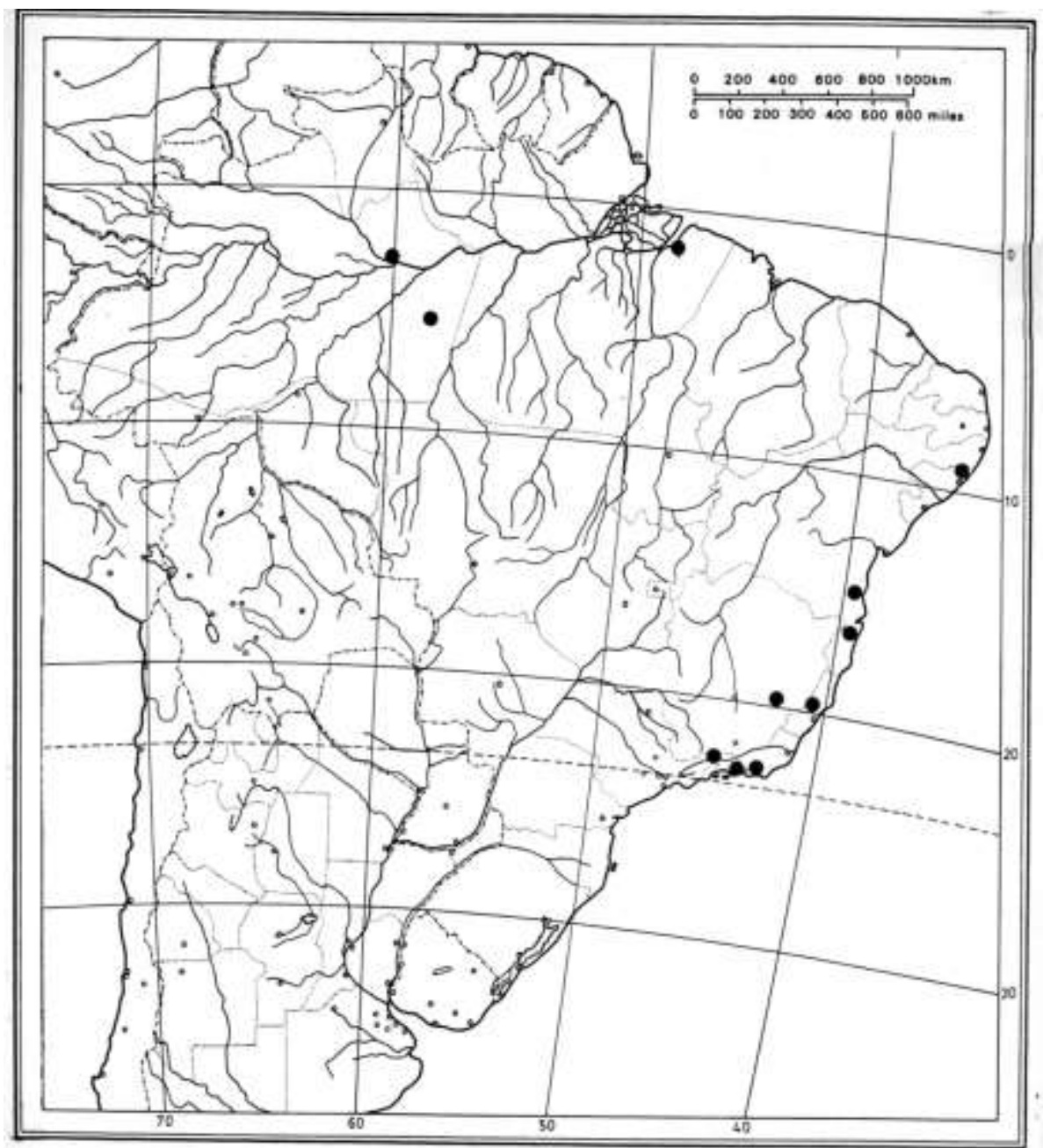

Fig. 58 - Distribuição geográfica de Neea verticillata.

3. PISONIA L., Gen. pl.: 42.1737.

Espécie-tipo: Pisonia aculeata L.

Pallavia Vell., Fl. flumin.: 151. 1829.

Árvores inermes ou arbustos com ramos escandentes espinescentes. Folhas opostas, subopostas ou às vezes fasciculadas em ramos curtos ainda não desenvolvidos, sempre longo-pecioladas. Inflorescências terminais em ramos curtos nodosos e com muitas gemas, geralmente em cimeiras capitadas aglomeradas, raramente em cimeiras corimbiformes laxas, normalmente alongando-se bastante na frutificação, especialmente os ramos distais; bractéolas geralmente 3 , raramente 2 , no ápice do ramo distal da inflorescência logo abaixo da flor, espaçando-se em espiral na frutificação, raramente isoladas na base dos ramos. Flores diclinas, pequenas, usualmente 5-meras, prefloração induplicado-valvar, sépalas unidas. Flores estaminadas companuladas, lobos denteados geralmente reflexos; estames 5-8, desiguais, salientes, filetes unidos na base; anteras elípticas rapidamente deiscentes; pistilódio sem estigma desenvolvido. Flores pistiladas tubulares, lobos denteados geralmente eretos; estaminódios presentes ou reduzidos a um disco basal ao redor do ovário; ovário com estigma penicelado ou curto-franjado. Infrutescência com ramos patentes. Antocarpos secos, clavados, 5-ou 10-angulados, com séries longitudinais de glândulas nos ângulos; glândulas com estipite viscoso e ápice capitado não viscoso. Fruto membranáceo. Embrião reto; cotilédones desiguais, orbiculares, enrolados lateralmente.

O gênero Pisonia foi descrito por Linnaeus em 1737 com uma referência a tab.11 de Plumier (apud Dumas 1988). A autora mostra em seu trabalho uma cópia da descrição e da tábula de Plumier, onde consta que foi visto apenas uma espécie, "Pisonia aculeata fructu glutinoso \& racemoso", que então caracteriza o gênero. 
Posteriormente Linnaeus (1753) descreveu duas espécies no gênero, incluindo-as na Classe Dioicia: $P$. aculeata da América meridional e $P$. mitis da Índia. A primeira dessas espécies foi descrita como tendo espinhos e frutos glandulosos, e certamente está bem posicionada no gênero conforme discutido por Dumas (1988). A segunda espécie foi caracterizada como destituída de espinhos e contém duas referências, uma a "Rheed, Hort. Malab. 7:33, t. 17", e a outra a "Amm. herb. 582". Contudo, a descrição original de Rheede (1688) cita a planta como espinhosa, e a tab. 17 mostra um ramo com raminhos bem opostos e folhosos, com folhas opostas em cada ramo, e em cada par de folhas aparece um par de espinhos ou projeções acima da inserção das folhas e mais ou menos interpeciolares; também, as flores e frutos são isolados, e estes parecem ser bicarpelares, semelhantes aos do gênero Diodia (Rubiaceae). Não foi visto qualquer material de Rheede, mas a descrição e ilustração sugerem a probabilidade desta referência ser uma Rubiaceae da Índia e segundo Stemmerik (1964) poderia ser uma $P$. aculeata com frutos galhados. Segundo Choisy (1849) $P$. mitis não seria uma Nyctaginaceae. Entretanto Stemmerik (1964) revendo os tipos de Pisonia do Velho Mundo, encontrou no herbário LE o material "Amin. herb. 582", a outra referência de Linnaeus a $P$. mitis, e comenta que trata-se da mesma Pisonia aculeata L., tendo sido por isso sinonimizada por ele.

O número de espécies no gênero Pisonia foi ampliado com a inclusão de muitas espécies normalmente sem espinhos, e com frutos secos glandulosos ou com frutos carnosos. A aceitação das espécies com frutos carnosos no gênero Guapira, com a inclusão de muitas espécies descritas antes em Pisonia "sensu lato" torna o gênero Pisonia "sensu stricto" mais homogêneo.

Na Tribo Pisonieae, Pisonia caracteriza-se pela presença de glândulas no antocarpo e nas flores estaminadas e pistiladas, sendo este o caráter que diferencia o gênero de Guapira e Neea. A presença de espinhos é um caráter específico e não genérico, ocorre apenas em $P$. aculeata $L$.

No Brasil, ocorrem três espécies de Pisonia, diferenciadas basicamente pelo antocarpo, e especialmente, pelo tipo e disposição das glândulas no antocarpo: P.aculeata, $P$. ambigua Heimerl e $P$. zapallo Griseb.

Exceto pela espécie $P$. aculeata que tem distribuição pantropical, as outras duas espécies do gênero que ocorrem no Brasil exibem distribuição mais restrita, no sul do continente sulamericano.

Chave para as espécies de Pisonia no Brasil

1. Arbustos escandentes, ramos espinhosos; folhas frequentemente orbiculares a largo-elípticas; flores estaminadas com lobos do cálice reflexos; flores pistiladas sem estaminódios, disco basal ao redor do ovário; antocarpos 4-5-angulados, cada ângulo com 4-5 fileiras longitudinais multisseriadas de glândulas capitadas em toda sua extensão 1. P. aculeata

1. Árvores inermes; folhas elíptico-orbiculares, oblongo-elípticas ou sub-rômbicas; flores estaminadas com lobos do cálice pouco ou nada reflexos; flores pistiladas com estaminódios, ou estes às vezes reduzidos a um disco lobado; antocarpos 5-10-angulados, cada ângulo com uma fileira longitudinal unisseriada de glândulas capitadas ou não capitadas, exceto na terça parte inferior.

2. Folhas geralmente oblongo-elípticas a sub-rômbicas, 4,0-25,0 cm compr.; inflorescência em cimeira corimbiforme laxa, 2,5-8,0 cm larg.; antocarpos 5-angulados, glândulas com estipite geralmente recurvado para a base, ápice frequentemente não capitado

2'. Folhas geralmente elíptico-orbiculares, 2,5-9,5 cm compr.; inflorescência em cimeira capitadoaglomerada, 0,9-2,0 cm larg.; antocarpos 10-angulados, glândulas com estipite geralmente ereto, ápice capitado 2. P. ambigua

3. P. zapallo

3.1. Pisonia aculeata L., Sp. PI. 2: 1026. 1753. Tipo: Tab.11, Nova Plantarum americanarum genero, Plumier: 1703 (detalhes); Tabula 227, fig 1, in "Plumier C., Plantarum americanarum" fasc. decimus Burman. 1760. (hábito) (lectótipo por Dumas 1988).

Pisonia mitis L., Sp. pl. 2: 1026. 1753. Tipo: Amman herb. 582 (holótipo LE, segundo Stemmerik 1964, n.v.).

Pisonia loranihoides H.B.K., Nov. gen. sp. 7: 153. 1825. Tipo: "in insula Cubae prope Guanavacoan", março, Humboldt \& Bonpland 1268 (holótipo P!). Syn. nov.

Pallavia aculeata Vell., FI. flumin.: 151. 1829; Icones 4: tab.12. 1831. Tipo: Icones 4: tab.12 (lectótipo, aqui designado).

Pisonia yaguá-pindá Parodi, Contrib. fl. Paraguay 2: 61. 1878. Tipo: Eberhard Munck of Rosenschold, s.n., n.v. ( Stafleu \& Cowan 1983).

Pisonia aculeata var. guaranitica Chodat in R. Chodat \& L. Rehfous, Bull. Soc. Bot. Geneve 17: 164. 1926. Tipo: Paraguai, Vila Rica, I.1905, E. Hassler 8615 (holótipo G!, isótipo P!). Syn. nov.

Fig. 59

Nomes vulgares: tapaciriba, espora-de-galo (Reitz 1970); yagua-pinda (Toursarkissian 1974); espino-negro, cagalero, ufia-de-gato (Standley 1937b); garabato-prieto, uma-del-diablo (Standley 1911).

Arbusto lenhoso, escandente, 2,0-25,0 m alt. Ramos patentes a retronásticos, alongados, entrenós 3,0-15,0 cm compr., aculeados, córtex marromavermelhado quando seco, ramos distais frequentemente fistulosos; às vezes ramos curtos sem folhas, 1,5-3,5 cm compr., acúleos terminais; gemas 


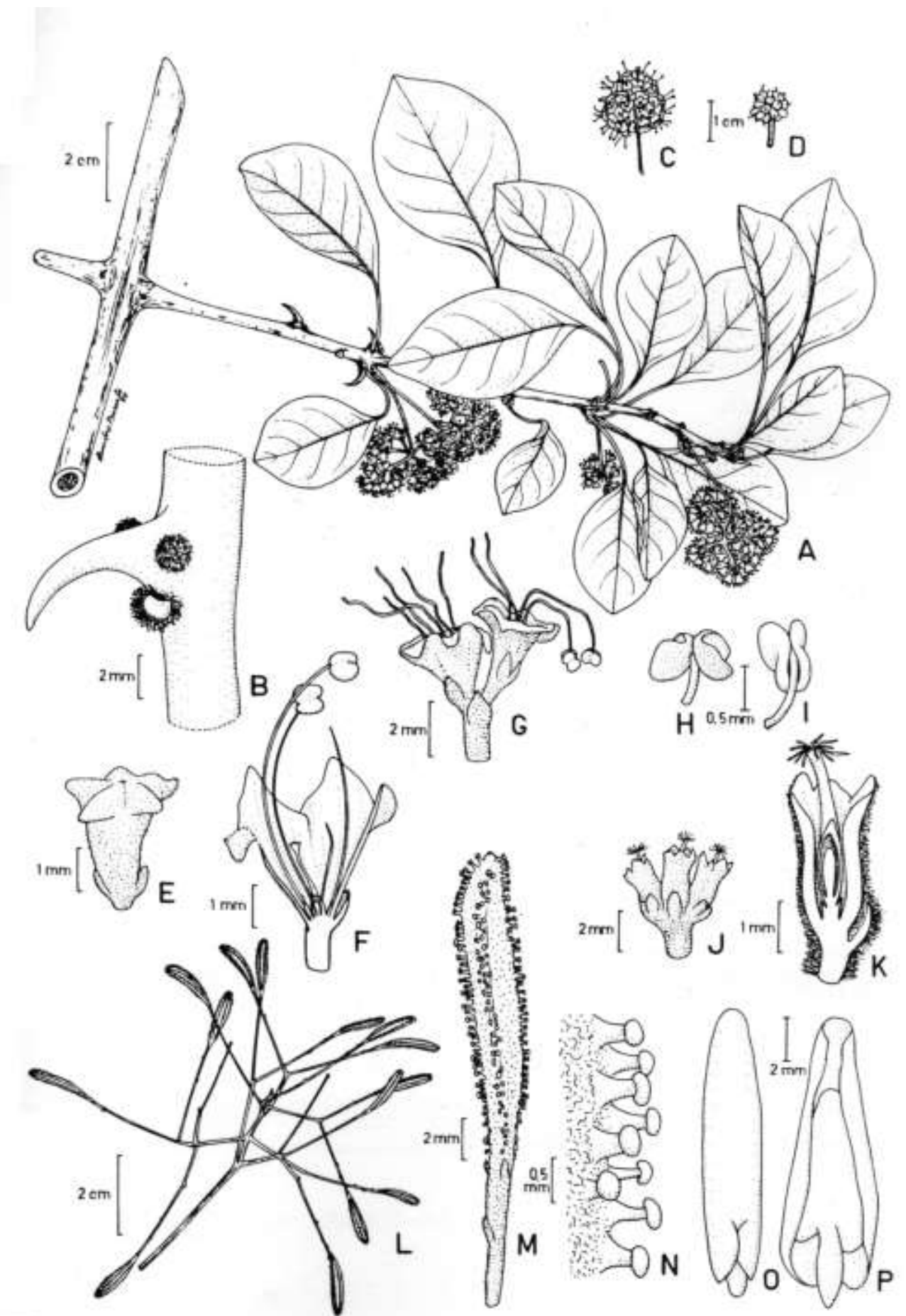

Fig. 59 - Pisonia aculeata: A. Ramo estaminado com inflorescências adultas mostrando a típica ramificação escandente da espécie. B. Detalhe do espinho mostrando sua natureza caulinar, acima de uma cicatriz foliar e com duas gemas laterais pilosas. C. Inflorescência estaminada. D. Inflorescência pistilada. E. Botão estaminado. F. Flor estaminada em corte longitudinal. G. Flor estaminada com minúsculas glândulas distinguindo-se dos tricomas por estarem dispostas em séries. $\mathrm{H}$. Detalhe das anteras com tecas opostas entre si. I. Detalhe das anteras totalmente abertas. J. Cimeira terminal trímera, na planta feminina. K. Flor pistilada em corte longitudinal, mostrando o disco de origem estaminodial. L. Ramo com infrutescências mostrando os ramos distais alongados. M. Antocarpo com glândulas; notar as bractéolas distanciadas pelo alongamento do ramo terminal da inflorescência. N. Detalhe das glândulas capitadas. O. Embrião reto em vista dorsal. P. Embrião reto em vista frontal, com cotilédones desiguais e enrolados. (A, B, E-I - G. Pabst 7017; C - E. Hassler 8615; D, J-K - E. Hassler 3165; L-P S. Colli et al. s.n. FUEL 7541). 
pubérulo-amareladas; acúleos retos ou recurvados, 10$16 \times$ ca. $3 \mathrm{~mm}$ na base, agudos, pungentes, axilares, frequentemente com cicatriz foliar embaixo na base e duas gemas laterais basais. Folhas com pecíolo 0,6$3,7 \mathrm{~cm}$ compr. pubérulo a tomentoso-amarelado quando jovem, glabrescente. Laminas opostas, às vezes alternas em ramos alongados ou fasciculadas em ramos curtos, raramente verticiladas, orbiculares, oblongo-orbiculares, elípticas, ovado-elípticas ou obovado-elípticas, 2,8-11,5 x 1,9-10,5 cm, base geralmente obtusa a arredondada, pouco atenuada no pecíolo, ápice obtuso a arredondado, comumente curto-acuminado, membranáceas, opacas, nervuras secundárias 3-6, pouco ou não salientes; face superior glabra, às vezes nervura mediana pubérula quando nova; face inferior glabrescente, exceto nervura mediana pubérula, mais clara; Inflorescências em cimeiras aglomeradas ou pouco laxas, globosas a hemisféricas, 1,1-2,5 cm larg., piloso-amareladas a glabrescentes, as pistiladas em geral mais aglomeradas; pedúnculo 6-38 mm compr., ca. $1 \mathrm{~mm}$ espessura, pubérulo; ramos da inflorescência opostos ou dicotômicos; na frutificação, pedúnculos e ramos pouco alongados, até $1,5 \mathrm{~cm}$ compr., ramos distais não espessados, muito alongados até $2,8 \mathrm{~cm}$ compr.; brácteas na base dos ramos terminais, elípticas, pilosas, decíduas, 1,5-2,5 mm compr.; bractéolas 2-3 na base das flores, suborbiculares a oblongas, às vezes em níveis diferentes, ca. 1,5 x 0,5 mm, pilosas, na frutificação distanciadas e espaçadas até $7 \mathrm{~mm}$ pelo alongamento dos ramos distais. Flores 4-5meras, verde-amareladas; botões clavados, ápice truncado, induplicações salientes. Flores estaminadas campanuladas, 2,0-5,0 x 2,0-5,0 mm; cálice pubéruloamarelado, 4-5 séries incompletas de minúsculas glândulas pouco visíveis, lobos do cálice denteados, margem reflexa; estames 6-8, desiguais, salientes até $5 \mathrm{~mm}$, filetes filiformes, unidos, espessados na base, anteras elípticas, avermelhadas quando secas, tecas usualmente iguais; pistilódios elipsóide, atenuado em estilete cilíndrico, estigma rudimentar pouco fimbriado, óvulo basal ereto não se desenvolvendo. Flores pistiladas cilíndricas, tubulosas, ligeiramente estreitadas no alto, 2,0-3,0 x 1,0-1,5 mm; cálice carnoso mais espessado no ápice, pubérulo a tomentoso, lobos do cálice às vezes glabros; estaminódios ausentes, disco anular delgado na base do ovário, permanecendo no fruto; ovário elipsóide, esthete cilíndrico, saliente por até $1,5 \mathrm{~mm}$; estigma penicelado-franjado, ramos desiguais. Antocarpo seco, ligeiramente oblíquo ao ramo distal da infrutescência, cilíndrico-clavado, 7,0-16,0 x 2,0-5,5 mm, atenuando na base, truncado no ápice, 4-5-anguloso costado, faces pilosas, 4-5 fileiras completas de glândulas, 1-2seriadas nas costas dos ângulos, raramente 1-2 glândulas esparsas na face; glândulas capitado-pediceladas, pedicelo secretor mucilaginoso-viscoso, espessado na base, escuro, ereto, cabeça não secretora, pouco mais clara. Fruto membranáceo, ajustado ao antocarpo, totalmente aderido a testa da semente; embrião reto, cotilédones pouco carnosos; perisperma amiláceo, branco, pouco gelatinoso, translúcido nas bordas.

Pisonia aculeada é a única espécie do gênero que possui espinhos. Estes são ramos modificados, como se pode ver pelas cicatrizes foliares na sua base e pelas gemas laterais normalmente presentes. Além disso frequentemente o espinho pode se desenvolver em um ramo vegetativo ou reprodutivo. Às vezes ocorrem ramos curtos de até $3,5 \mathrm{~cm}$ de comprimento, sem folhas e com ápice espinescente.

Além dos espinhos, a espécie é facilmente diferenciada das demais de Pisonia no Brasil pelos ramos patentes ou retronásticos, e pelos antocarpos com 4 a 5 fileiras completas de glândulas desde a base até o ápice, uni ou bisseriadas.

O material-tipo de $P$. I oranthoides é um ramo pistilado, igual aos demais materiais examinados de $P$. aculeata, com acúleos e folhas um pouco mais espessas e glabras, mas isso não justifica a separação desta espécie, aqui sinonimizada.

A descrição e ilustração de Pallavia aculeata Vell. não apresentam diferenças em relação a $P$. aculeata, o que leva à aceitação de sua sinonimização proposta por Reitz (1970). Os motivos para a lectotipificação da tab.12 de Vellozo (1831) podem ser revistos nos comentários de Guapira opposita.

A descrição de Pisonia yaguá-pindá concorda perfeitamente com a variação mostrada pelos materiais estudados, e está sendo aceita a sinonimização proposta por Toursarkissian (1974). No protólogo não consta menção a material-tipo, entretanto Stafleu \& Cowan (1983) esclarecem que Parodi adquiriu exemplares de herbário e notas manuscritas de Eberhard Munck of Rosenschold depois que este foi assassinado no Paraguai.

A análise do tipo de $P$. aculeata var. guaranitica mostra que as diferenças mencionadas pelos autores, como inflorescência capituliforme, filetes de até $7 \mathrm{~mm}$ compr. e antocarpos longo-glandulosos, enquadramse na variação dos materiais examinados de $P$. aculeata, não sendo suficientes para distinguir a variedade.

Já $P$. aculeata var. hirsutissima está sendo incluída na sinonímia de $P$. ambigua Heimerl.

Heimerl (1896), Schmidt (1872) e Reitz (1970) citam outros sinônimos desta espécie, porém sem referência a tipos, havendo portanto necessidade de melhor verificação.

Em materiais herborizados de $P$. aculeata frequentemente ocorre queda dos antocarpos, porém Chodat \& Rehfous (1926) relatam que as infrutescências com seus antocarpos maduros destacam-se da planta por inteiro e caem na submata, sendo estas infrutescências inteiras que aderem aos pêlos dos animais. Assim, a cabeça da glândula, que não é secretora, aparentemente impede que as infrutescências fiquem aderidas aos ramos e folhas do dossel. Esses mesmos autores descrevem a origem das glândulas a partir de tricomas e informam que as flores são visitadas por dípteros e pequenos himenópteros.

Com relação ao androceu de $P$. aculeata, 
Sharma (1963) nota que, apesar de ser geralmente formado por mais de cinco estames de comprimentos desiguais, os traços de estames originam-se em um único ciclo.

O pólen de $P$. aculeata foi ilustado e descrito por Barth \& Barbosa (1972) como sendo esferoidal, 3colpado, de superfície espinulosa, teto perfurado, com colpos irregulares cobertos por elementos isolados da sexina. Segundo os autores, o pólen de $P$. ambigua é semelhante ao de $P$. aculeata, diferenciado apenas pelas dimensões médias dos grãos e das camadas componentes da exina.

Pisonia aculeata floresce de fevereiro a agosto com maior expresssão em julho e agosto; frutifica de abril a novembro.

Distribuição geográfica (Fig. 60): Trata-se de espécie de ampla distribuição geográfica, ocorrendo na América do Sul, Central e do Norte, Ásia, África, e Ilhas do Pacífico. Na América do Sul é registrada para Colômbia (Standley 1931b), Peru (Liesner 1993) e Argentina (Toursarkissian 1974). Porém segundo Standley (1937a) P. aculeata não ocorre no Peru. No Brasil, a espécie tem sua maior frequência nos estados sulinos, com raros registros na Amazônia.

Material selecionado: Brasil. Bahia: Cachoeira, $L$. Scardino et al. GPC 758, 27.IX.1980, fr. (ALCB, HUEFS). Mato Grosso do Sul: Corumbá, A. Rego 668, 29.VII.1986, fr. (CPAP). Pará: Óbidos, A. Ducke s.n., 14.IX.1927, infl. jovem (RB 1160). Paraná: Alvorada do Sul, G. Hatschbach 23490 , 14.II.1970, fl. est. (MBM, UPCB). Permambuco: Nazaré da Mata, J.C. Moraes 1315, 15.XI.1954, fr. (SPF, SPSF). Rio de Janeiro: Cabo Frio, D. Araujo \& N.C. Maciel 7487, 27.V.1986, infl. jovem (GUA). Rio Grande do Sul: Guaíba, J.L. Waechter 498, 2.IV.1977, fr. (ICN). Santa Catarina: Florianópolis, $R$. Klein \& A. Bresolin 8644, 31.III.1970, fl. est. (ICN, PACA). São Paulo: Araraquara, A. Loefgren CGGSP 4414, 22.III.1899, infl. jovem (SP). fl. est. (P).

Antilhas. Guadalupe, L. Rodrigues 4144, 18.III.1936,

Arábia. W.Barbey 1375, 23.I.1989, fr. (BR).

Argentina. Corrientes, A. Krapovickas et al. 23626, 20.VI.1973, fl. est. (R).

Austrália. $13^{\circ} 45^{\prime} \mathrm{S}, \quad 30^{\circ} 41^{\prime} \mathrm{E}, \quad$ S.T. Blake 16633,

27.VII.1946, fr. (SP). pist./fr. (P)

Cuba. Havana, A.H. Curtiss 668, 26.IV.1905, fl.

Filipinas. G.E. Edario 17810, III.1953, fr. (K).

Java. Zollingero 2163, s.d., fr. (P).

México. Veracruz, M. Nee et al. 26587, s.d., fr. (R). (MO, SPF)

Paraguai. Alto Paraná, W. Hahn 1654, 10.IX.1983, fr.

Porto Rico. P. Sintenis 6675, 12.IV.1987, fl. pist. (P). Timor. Herb. Jussieu 4634, s.d., fl. est. (P).

Uganda. T.J. Synott 1329, 2.XII.1972, fl. est. (K).

3.2. Pisonia ambigua Heimerl, Denkschr. Akad. Wiss., Wien, Math.-nat. 79: 236. 1908.Tipo: Brasil, Minas Gerais, Caldas, Regnell III-1022, fl. est. e pist. (lectótipo BR!, isolectótipo P!).

Pisonia aculeata var. hirsutissima J.A. Schmidt in Mart., FI. Bras. 14(2): 354. 1872. Tipo: Brasil, Minas Gerais, Caldas, Regnell 111-1022, s.d., fl. est./fr. (lectótipo BR!; isolectótipo P!, aqui designados). Syn. nov.

Fig. 61

Nomes vulgares: maria-mole, maria-faceira (Reitz 1970).

Arbustos a árvores, eretos, inermes, 1,7-18,0 m alt., fuste cilíndrico, até $5 \mathrm{~m}$. alt, 10,0-28,0 cm diâm., madeira mole, casca áspera, copa ca. $7 \mathrm{~m}$ diâm.; ramos distais carnosos, glabros, dicotômicos oblíquos, não patentes, quando secos compressos, cicatrizes várias, semicirculares, salientes, gemas pubéruloferrugíneas a ocre. Folhas com pecíolo 1,0-6,5 cm compr., canaliculado, pubérulo a glabrescente. Laminas opostas ou subopostas, elípticas, largoelípticas, elíptico-orbiculares, às vezes obovadas ou sub-rômbicas, as menores em geral orbiculares, $(4,1)$ 9,2-16,1 $(24,5) \times(2,2) 4,4-6,9(12,8) \mathrm{cm}$, base aguda, frequentemente assimétrica, raramente obtusa, pouco atenuada no pecíolo, ápice agudo a ligeiramente obtuso, frequentemente curto-acuminado, às vezes caudado, as menores de ápice arredondado, membranáceas, normalmente discolores, mais claras embaixo, opacas, nervuras secundárias 5-8; face superior geralmente glabra, às vezes pilosa especialmente nas nervuras, nervuras não ou pouco salientes; face inferior em geral pilosa, mais densa nas nervuras, nervuras salientes, vênulas pretas quando secas e não salientes; Inflorescências terminais e axilares, em cimeiras corimbiformes laxas, hemisféricas, 2,5-8,0 cm diâm., até $12,0 \mathrm{~cm}$ diâm. na frutificação, comumente hirsutas; pedúnculo 0,9-4,7 $\mathrm{cm}$ compr., em geral ramificado dicotomicamente, na frutificação alongado até $6,2 \mathrm{~cm}$ compr., ramos distais di-tricotômicos, ca. 4,0 mm compr., alongados até 18 $\mathrm{mm}$ compr. na frutificação, oblíquos, não patentes; brácteas raramente nos ramos da inflorescência deltóides, ca. 3,0 mm compr.; bractéolas 3, na base das flores, deltóides a lineares, 1,0-3,0 mm compr., pubérulas, distanciadas entre si ca. $4 \mathrm{~mm}$ na frutificação. Flores 4-5 meras, verdes; botões clavados de ápice truncado ou ligeiramente arredondado, induplicações em geral salientes, quase sempre muito pilosos. Flores estaminadas campanuladas, 4,0-6,2 $\mathrm{x}$ $2,5-4,0 \mathrm{~mm}$, às vezes ligeiramente pediceladas, verdeamareladas, pubérulas; lobos do cálice eretos ou pouco reflexos, muitas vezes glabros, 5 séries longitudinais de glândulas minúsculas visíveis na região mediana; estames $6-8$, salientes até $3 \mathrm{~mm}$ do cálice, brancos; pistilódio cônico-cilíndrico, estigma rudimentar incluso ou pouco saliente. Flores pistiladas cilíndricas a subcampanuladas, atenuadas na base, 2,0-4,0 x 1,1-2,3 mm, verdes, pubérulas, às vezes lobos glabros; estaminódios 4-8, minúsculos, às vezes dentiformes pouco desenvolvidos; ovário frequentemente curto-estipitado, estigma ramificado penicelado, alvo, saliente por até $1 \mathrm{~mm}$. Antocarpo inicialmente elipsóide, depois clavado, 14-24 x 3,0-5,8 $\mathrm{mm}$, 5-anguloso, piloso nas faces, 5 fileiras longitudinais incompletas de glândulas 1-2-seriadas nos ângulos, terço inferior do antocarpo sem 


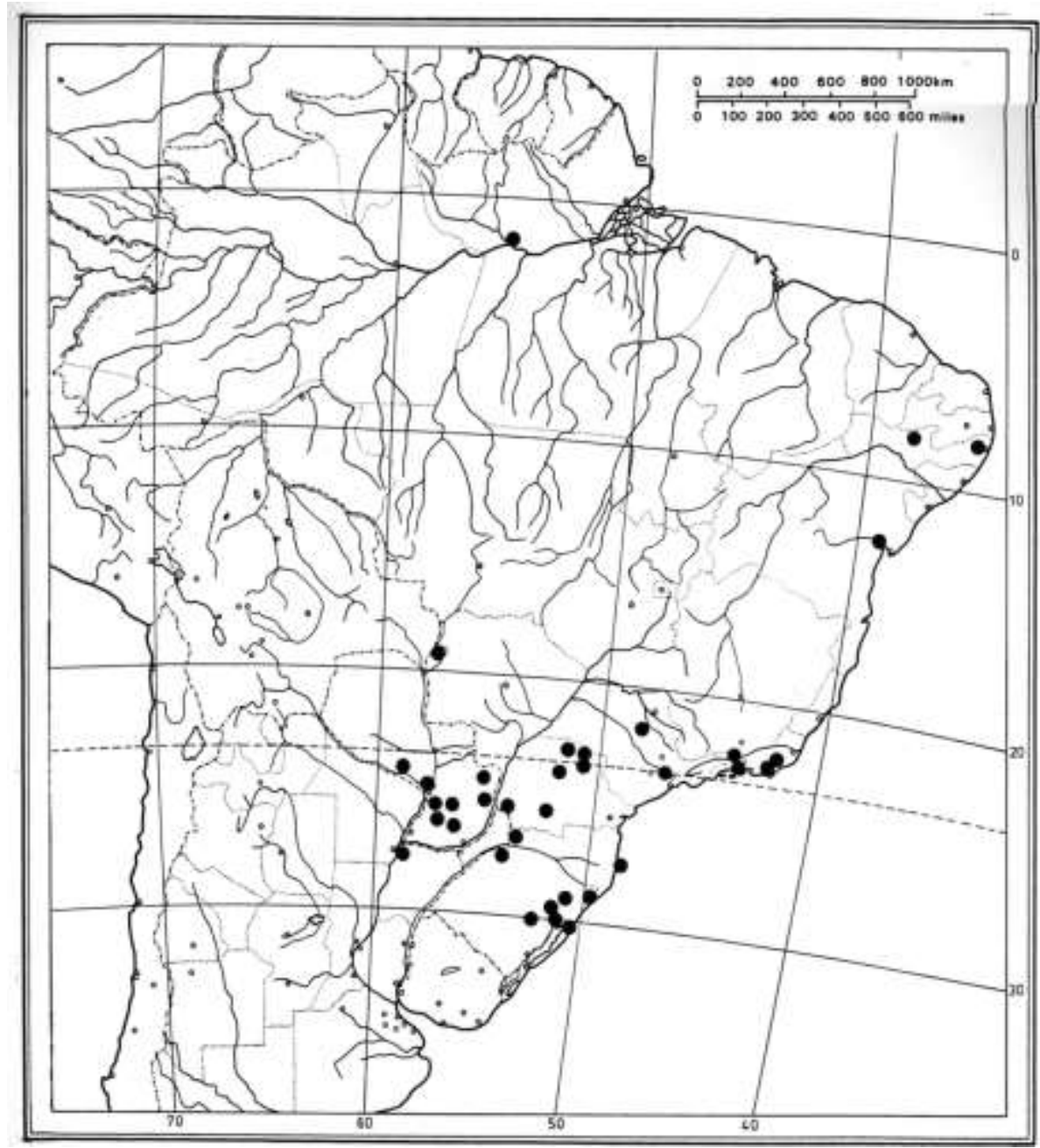

Fig. 60 - Distribuição geográfica de Pisonia aculeata.

glândulas, raramente com 1-3 glândulas menores nas faces; glândulas de base alargada, em geral não capitadas, as mais desenvolvidas na região distal, ápice não viscoso, agudo a obtuso, normalmente recurvado para a base do antocarpo; embrião reto, cotilédones carnosos, ondulados, pouco nervados, radícula reta; perisperma escasso, farináceo ou gelatinoso.

A descrição do protólogo de Pisonia ambigua (Heimerl 1908), baseia-se em materiais estaminados e em materiais com frutos, posteriormente Heimerl (1912) descreveu as flores pistiladas correspondentes desta espécie (Rojas 10426).

Pisonia aculeata var. hirsutissima foi baseada em quatro síntipos, dos quais foi escolhido como lectótipo Regnell 111-1022. Esse material também era um dos síntipos de $P$. ambigua Heimerl, mas a variedade não havia sido sinonimizada pelo próprio autor, sendo aqui sinonimizada.

Pisonia ambigua foi considerada sinônimo de P. zapallo por Toursarkissian (1975), baseando-se apenas no espécime Rojas 10426. Embora este tenha flores pistiladas e frutos jovens, já apresenta as glândulas típicas de $P$. ambigua, recurvadas para a base do antocarpo e não capitadas. Além disso, sua inflorescência em cimeira corimbiforme laxa caracteriza-o como $P$. ambigua, bem como as folhas grandes e largo-elípticas, e não se justifica a sinonimização de Toursarkissian (1975).

Segundo Barth \& Barbosa (1972), o grão de pólen de $P$. ambigua é muito semelhante ao de $P$. aculeata. Ver comentários em $P$. aculeata.

Exemplares estéreis de $P$. ambigua podem ser facilmente confundidos com espécies de Guapira e Neea, devido a semelhança nas folhas. Mesmo exemplares férteis, especialmente os de plantas estaminadas, são às vezes encontrados identificados em herbários como Neea ou Guapira. O antocarpo seco e glanduloso separa-a definitivamente destes dois gêneros, que possuem frutos carnosos e não glandulosos. Tanto os botões quanto as flores estaminadas ou pistiladas, com cinco séries de minúsculas glândulas e geralmente bem pilosos, 


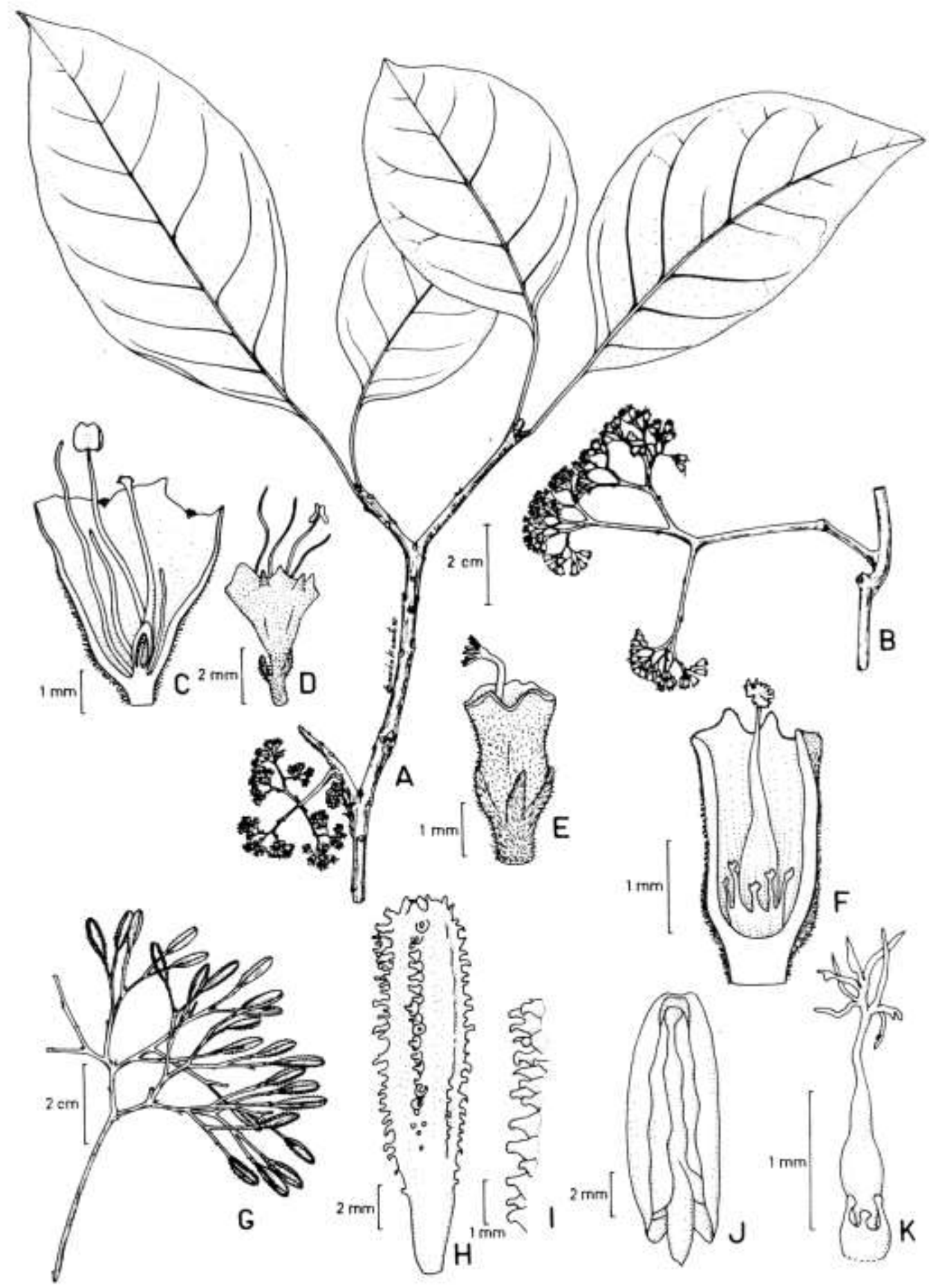

Fig. 61 - Pisonia ambigua: A. Ramo com inflorescência estaminada. B. Inflorescência estaminada bem desenvolvida. C. Flor estaminada em corte longitudinal mostrando pistilódios com estigma e óvulo não desenvolvidos. D. Flor estaminada mostrando as séries de glândulas no perianto. E. Flor pistilada com perianto pouco mais carnoso e séries de glândulas. F. Flor pistilada em corte longitudinal através de uma série de glândulas. G. Infrutescência. H. Antocarpo com 5 séries quase completas de glândulas e uma série intermediária pouco desenvolvida. I. Detalhe das glândulas com ápice voltado para a base do antocarpo. J. Embrião reto em vista frontal. K. Ovário de flor pistilada, sobre curto ginóforo e estaminódios. (A - G. Hatschbach 9238; B-D N. Taroda et al. 6624; E-F, K - Klein \& Bresolin 7519; G-J - J.L. Waechter 1393). 
caracterizam $P$. ambigua e podem ser usados para distingui-la de Guapira ou Neea.

A etiqueta do espécime Waechter 1393 (ICN) informa que os frutos desta espécie caem no solo ainda ligados à infrutescência, e provavelmente esta espécie tem a mesma estratégia de dispersão dos frutos já comentada em $P$. aculeata.

Segundo Brown et al. (1985), P. ambigua é uma espécie de porte médio a grande (10-20 $\mathrm{m}$ alt.) que predomina do estrato médio (11-25 m alt.) em uma floresta semidecídua do noroeste argentino. Neste estudo fitossociológico $P$. ambigua comparece como a espécie com maior IVI, Índice de Valor de Importância (abundancia, frequência e dominância).

Distribuição geográfica (Fig. 62): P. ambigua é espécie florestal, ocorrendo com maior frequência nos estados do Sul do Brasil, alcançando o sul da Bahia pela Mata Atlântica (Fig. 68). Além do Brasil, ocorre no Paraguai, Argentina e na Amazônia peruana (Liesner 1993). A espécie floresce de março a outubro com maior expressão em agosto e setembro; frutifica de setembro a novembro.

Material selecionado: Brasil. Bahia: Ilhéus, T.S. Santos 3941, 31.X.1984, fl. pist. (CEPEC, SPF). Espírito Santo: Linhares, D.A. Folli 93, 27.VIII.1979, fl. est. (CVRD, HRCB, RBR, SPF). Paraná: Monte Alegre, A.P. Duarte et al. 5267, 4.VIII.1960, fl. est. (HB, RB). Rio de Janeiro: Rio de Janeiro, P. Occhioni 701, 18.IX.1946, fr. (RB). Rio Grande do Sul: Marcelino Ramos, J.A. Jarenkow 739, 24.IX.1987, fr. (PEL); Tenente Portela, J.L. Waechter 1393, 4.X.1979, fr. (ICN, RB). Santa Catarina: Palhoça, Reitz e Klein 3664, 7.IV.1956, bot. est. (PACA, PEL, UPCB). São Paulo: São Sebastião, J.R. Pirani e O. Yano 753, 26.VII.1983, fl. pist./fr. (SP, SPF).

Paraguai. Sierra Amambay, T. Rojas 10426, IV.1907/1908, fr. (G, MO, P).

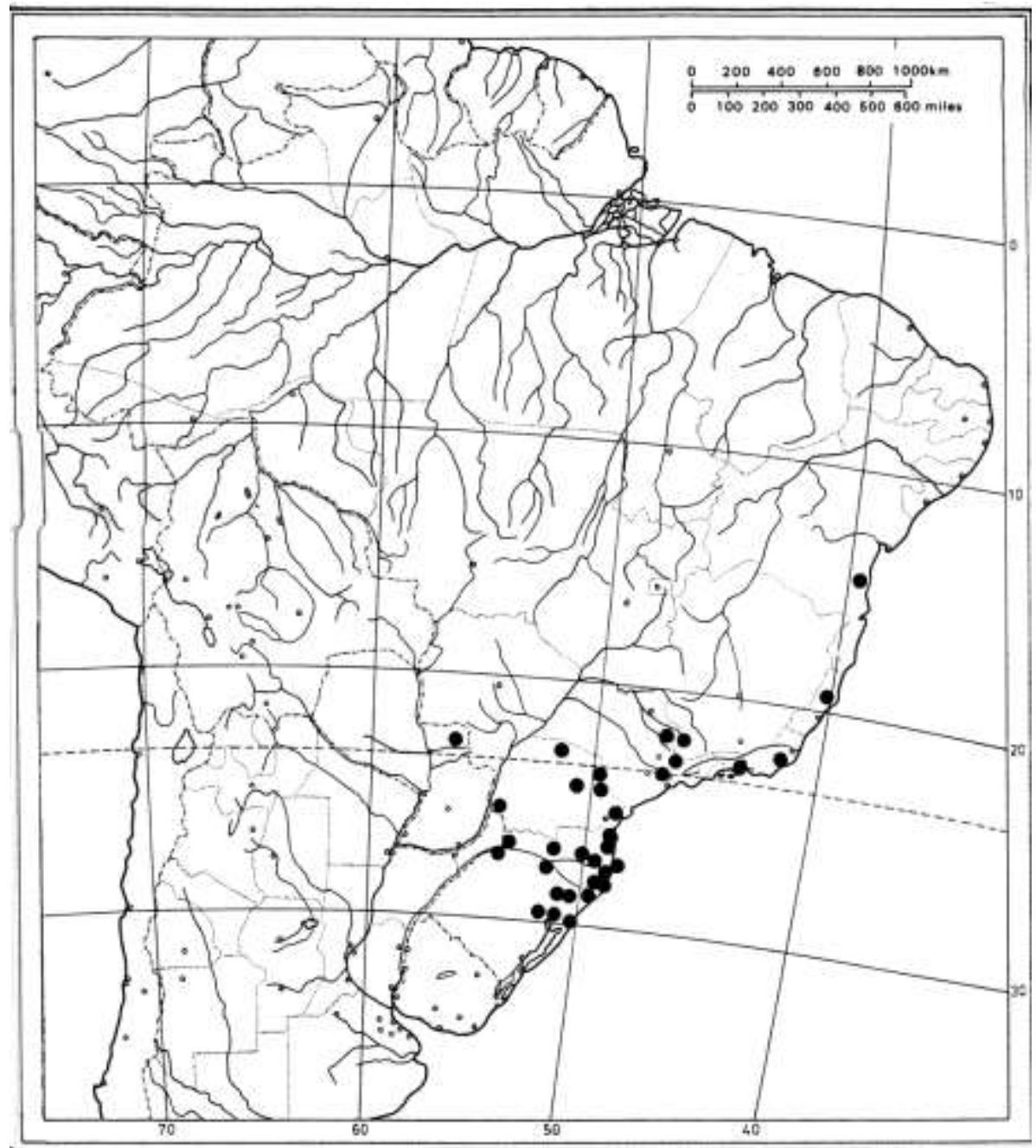

Fig. 62 - Distribuição geográfica de Pisonia ambigua. 
3.3. Pisonia zapallo Griseb., Symb. fl. argent.: 39. 1878. Tipo: Bolívia, "Tarija, prope Itau", Lorentz et Hieronymus 904, 17.VI.1873 (GOETT Lectótipo n.v., CORD Isolectótipo n.v., selecionados por Toursarkissian, 1975).

Fig. 63

Nomes vulgares: zapallo-caspi (Hess 1946); yuquirucu (Stoemi 1944); palo-de-zapallo, ombara (Standley 1931b).

Árvore ereta, 4-15 m alt., inerme, caducifólia, tronco liso, 50,0-95,0 cm diâm., ramificações dicotômicas, ramos oblíquos não patentes, geralmente sem folhas na floração, pouco compressos quando secos; usualmente muitos ramos curtos, lisos, glabros, ca. 2,0 cm compr., multi-gemados; gemas opostas a subopostas, piloso-amareladas. Folhas com pecíolo 0,8-2,8 cm compr., canaliculado, piloso a glabrescente. Laminas frequentemente fasciculadas em ramos curtos, opostas e subopostas em ramos desenvolvidos, pares desiguais, elípticas, largoelípticas, orbiculares, a obovado-orbiculares, raramente espatuladas, 2,6-9,5 x 1,5-6,6 cm, base aguda a obtusa, às vezes inequilátera, pouco atenuada no pecíolo, raramente longo-atenuada, ápice obtuso a arredondado curto-acuminado, raramente agudo, membranáceas a ligeiramente cartáceas, às vezes discolores, parda a verde-olivácea quando seca mais clara embaixo; face superior glabra, nervuras secundárias 4-8, não salientes; face inferior glabra exceto nervura mediana pilosa da base até o meio, nervuras secundárias não salientes, mais escuras que - limbo quando secas. Inflorescências em cimeiras aglomeradas globosas, 0,9-2,0 cm diâm., frequentemente terminais em ramos curtos, glabros, nodosos, cicatrizes várias, gemas pilosas no ápice, na frutificação até $12,0 \mathrm{~cm}$ diâm., esverdeadas; pedúnculo piloso-tomentoso, de 0,5-1,1 cm compr., alongado na frutificação até $4,7 \mathrm{~cm}$ compr.; ramos distais da inflorescência alongados na frutificação até $4,1 \mathrm{~cm}$ compr., abertos em ângulo reto; brácteas às vezes presentes nos ramos das inflorescências ca. 2,0 $\mathrm{mm}$ compr., tomentosas; bractéolas 3 , na base das flores, geralmente em níveis pouco diferentes, linearlanceoladas a oblongo-lanceoladas, ca. 1,5 mm compr., tomentoso-amareladas, na frutificação distanciadas e espaçadas nos ramos finais ca. $5 \mathrm{~mm}$ compr. Flores 4-5-meras, botões de ápice truncado, radiado, induplicações salientes. Flores estaminadas campanuladas, ápice pouco aberto, 2,2-4,0 x 1,5-4,0 $\mathrm{mm}$, verde-esbranquiçadas, pubérulas, especialmente na base, às vezes 10 séries de glândulas minúsculas pouco visíveis, lobos do cálice não reflexos; estames 5-8, salientes ca. 4,0 mm compr., pistilódio elipsóide, ca. 3,0 mm compr.; estilete cilíndrico, glabro a pouco piloso, truncado no ápice, sem estigma visível. Flores pistiladas cilíndricas, tubulosas, não ou pouco contraídas no ápice, verde-avermelhadas, tomentosas, sem glândulas; estaminódios 5-8, geralmente presentes, raramente sem estaminódios e com disco na base do fruto; ovário elipsóide ou cilíndrico, atenuado em estilete cilíndrico, estilete às vezes pouco piloso, saliente ca. $0,9 \mathrm{~mm}$, estigma penicelado, filamentos do estigma curtos, pouco desenvolvidos. Antocarpo cilíndrico-clavado, 10,0-21,0 x 3,3-5,3 mm, normalmente oblíquos ao ramo final da infrutescência, 10-costado, pubérulo-tomentoso, principalmente quando imaturo; 10 fileiras incompletas de glândulas unisseriadas, da região mediana até 0 ápice, inicialmente em sulcos, depois sobre as costelas; glândulas eretas, capitado-pediceladas, pediceloespessado na base, mucilagem viscosa entre os pedicelos; embrião reto, cotilédones carnosos pouco desiguais, margens às vezes enrugadas, perisperma farináceo-gelatinoso a totalmente gelatinoso.

Pisonia zapallo é facilmente separável de $P$. aculeata pelo porte arbóreo, ausência de espinhos e antocarpos com 10 fileiras incompletas e iguais de glândulas unisseriadas, enquanto que $P$. aculeata é escandente, espinescente e apresenta antocarpos com 5 fileiras completas de glândulas, geralmente bisseriadas. Pisonia zapallo difere de $P$. ambigua, outra espécie próxima, pela inflorescência aglomerada, globosa, capituliforme, e pelas glândulas do antocarpo, capitado-pediceladas e eretas, ao passo que $P$. ambigua possui inflorescência corimbiforme laxa, antocarpo com 5 fileiras incompletas de glândulas, intercaladas às vezes com 5 outras fileiras bem menores de glândulas esparsas, glândulas geralmente não capitadas e recurvadas para a base do antocarpo.

Os estudos anatômicos do lenho de P. zapallo, conduzidos por Puglia \& Norverto (1990), mostraram que sua estrutura e ontogenia não difere do lenho de outras espécies de Nyctaginaceae e concluem que este seria um caráter taxonômico constante nas espécies lenhosas da família.

Segundo Record \& Hess (1943), P. zapallo é uma das maiores árvores da Argentina atingindo até $21 \mathrm{~m}$ altura, com tronco de até $1 \mathrm{~m}$ de diâmetro, porém o lenho é macio e esponjoso, servindo localmente para confecção de caixotes e como combustível. Conforme Stoemi (1944) as árvores desta espécie destacam-se pela frondosidade, atingindo até $25 \mathrm{~m}$ altura e tronco até $3 \mathrm{~m}$ de diâmetro. Segundo este autor, as cinzas de seu lenho eram usadas na fabricação de sabão.

Distribuição geográfica e habitats (Fig. 64): $P$. zapallo tem distribuição restrita, abrangendo Argentina, Paraguai, Bolívia e extremo oeste do Brasil (apenas Mato Grosso e Mato Grosso do Sul). É mais frequente na região do Chaco na Argentina, e segundo Chodat \& Rehfous (1926) é uma das árvores mais características da formação chaquenha. Floresce de junho a outubro e frutifica de agosto a outubro. 


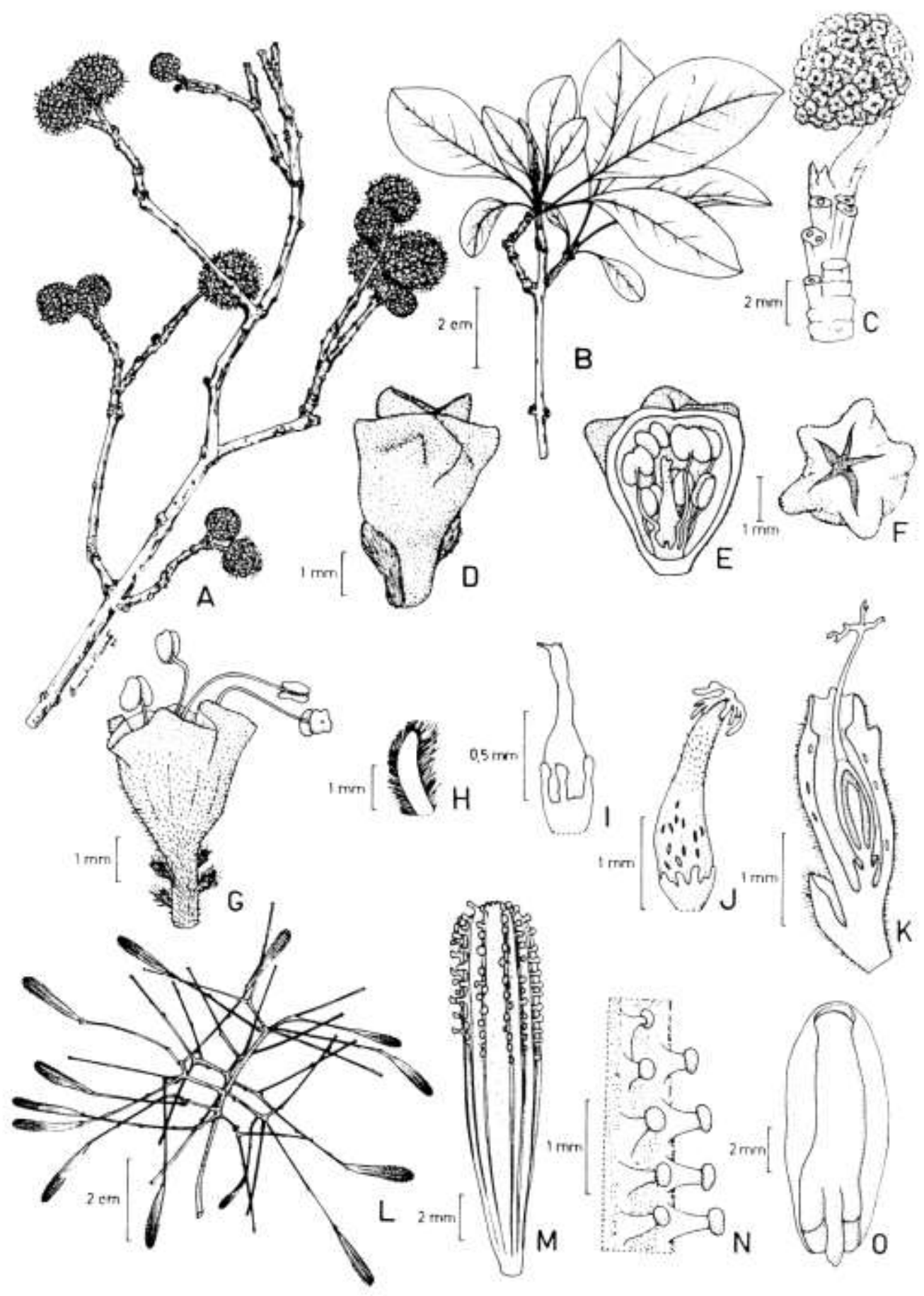

Fig. 63 - Pisonia zapallo: A. Ramo com inflorescências estaminadas e sem folhas. B. Ramo estéril, apenas com folhas. C. Inflorescência pistilada jovem em ramos curtos e aglomerados. D. Botão estaminado totalmente piloso. E. Botão estaminado em corte longitudinal. F. Botão estaminado em vista apical mostrando prefloração induplicado-valvar. G. Flor estaminada adulta com lobos do cálice não reflexos. H. Bractéola em vista interna. I. Ovário e estaminódios de uma flor pistilada. J. Idem, notando-se o estilete piloso e células com ráfides bem visíveis. K. Flor pistilada em corte longitudinal, com disco na base do ovário e células com ráfides no cálice. L. Ramo com infrutescência. M. Antocarpo com 10 séries incompletas de glândulas. $\mathrm{N}$. Detalhe das glândulas do antocarpo. O. Embrião reto em vista frontal com cotilédones pouco desiguais. (A-B, D-H - A Krapovickas \& C.L. Cristobal 13616; C, I-K - E. Hassler 12235-a; L-O - A. Pott 4919). 
Material examinado: Brasil. Mato Grosso: Cáceres, R.L. Loureiro 30, 22.VIII.1980, fl. est. (RB); Poconé, M. Silveira \& F.C. Silva s.n., 19.VIII.1989, bot. est. (FUEL 7287). Mato Grosso do Sul: Corumbá, A. Pott 4919, 15.VIII.1989, fr. (CPAP, SPF); Miranda, U.M. Resende 515, 3.VIII.1991, fr. (CGMS, SP, SPF).

Argentina. Corrientes, A. Krapovickas \& C.L. Cristobal 13616, 12.X.1967, fl. est. (CTES, IPA, SPF, UB); T.M. Pedersen 1812, 4.IX.1952, fl. est. (BR, P); T.M. Pedersen 7476, 26.X.1965, fl. est. (P); T.M. Pedersen 15574, 12.IX.1986, fl. est. (BR); Pilcomayo, I. Morel 3159, 18.VI.1947, fl. pist. (P); S. Luiz de Palmas, C.L. Cristobal et al. 1405, 2.XI.1975, fr. (BB)

Bolívia. M. Nee et al. 36579, 9.III.1988, infl. jovem $(\mathrm{SP})$

Paraguai. Concepción, E. Hassler 7187, VIII.1901/1902, fl. est. (G, MO, P); Gran Chaco, T. Rojas 2431, X.1903, fr. (G); Guarapi, B. Balansa 4120, X.1880, fr. (G, P); Pilcomayo, T. Rojas 295, VII.1906, fl. est. (G); San Bernardino, R. Chodat 21 p.p., 1914, fr. (G 5995-76/79); s.n., 1914 , fr. (G 5995-72/75); Ypacaray, E. Hassler 12235, VIII.1913, fl. est. (G, MO); E. Hassler 12235-a, VIII.1913, fl. pist. (G, MO); sem local, B. Balansa 2372, 1880, fl. est. (P).

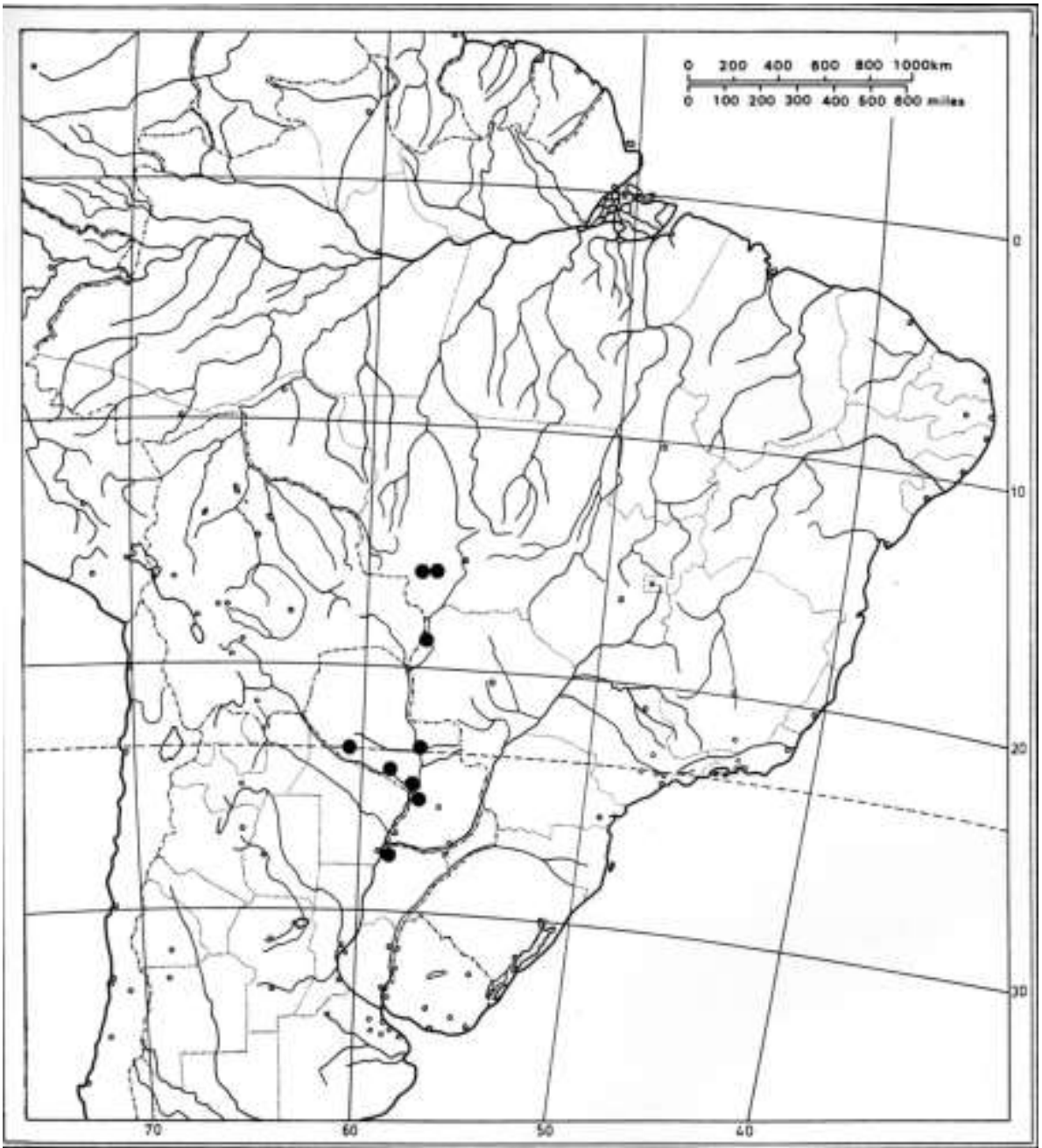

Fig. 64 - Distribuição geográfica de Pisonia zapallo. 


\section{Táxons duvidosos}

1. Mitscherlichia spectabilis Kunth, Vier Bot. Abh.: 210. 1832.

Esta espécie não possui descrição própria, mas o autor apresenta uma extensa descrição do gênero monotípico, baseada numa planta cultivada, não havendo citação de material e nem ilustração. $O$ gênero Mitscherlichia foi sinonimizado corretamente sob o gênero Neea por Heimerl (1934). Pelo tamanho e forma das folhas, forma e indumento das flores estaminadas, provavelmente a espécie poderia ser incluída em $N$. verticillata Ruiz \& Pay.

2. Neea altissima Poepp. \& Endl., Nov. Gen. sp. pl. 2: 45. 1838. Tipo: "in ripis elevatioribus lacus Egensis Brasiliae borealis, septembre floret".

Não foi localizado o espécime-tipo desta espécie. A descrição de Poeppig \& Endlicher (1838) indica que a folha tem forma muito variada, desde largo-elíptica até elíptica ou oblonga, com ápice acuminado, com 15-18 $\mathrm{cm}$ de comprimento e $6 \mathrm{~cm}$ de largura, as flores são pediceladas e o perianto é tubuloso de base ovada. Pelo tamanho e ápice da folha e pelo perianto tubuloso, talvez seja conspecífica com N. oppositifolia Ruiz \& Pav.

3. Neea divaricata Poepp. \& Endl., Nov. Gen. sp. pl. 2: 45. Tab.161 a-g. 1838. Tipo: "in silvis subandinis Peruviae ad Cuchero, novembre floret".

Segundo Standley (1937a) o material-tipo desta espécie seria Poeppig 1493, do qual o Field Museum teria uma foto oriunda do herbário de Berlim. Apesar do material-tipo ser proveniente do Brasil, para Standley (1937a) a espécie ocorreria também na Amazônia brasileira e colombiana. Não foi visto o espécime-tipo, porém pela descrição original de Poeppig \& Endlicher (1838) e pela descrição de Standley (1937a), é muito provável que ela se inclua na variação de $N$. oppositifolia. Os próprios autores de $N$. divaricata observaram essa possibilidade. Ver mais comentários sob N. oppositifolia.

4. Neea glomeruliflora var. latifolia Heimerl, Notizbl. Bot. Gart. Mus. Berl. 6: 127. 1914. Tipo: Brasil, "Estado de Amazonas, Menino de Deus, Jurua inf.", X.1901, Ule 5931.

Não foi localizado o material-tipo desta espécie, contudo, pela descrição apresentada por Heimerl (1914) parece tratar-se de $N$. ovalifolia. A espécie é caracterizada pelas folhas até $6,0 \mathrm{~cm}$ larg., bem discolores, com margens plicadas e nervuras laterais delgadas. Pelas presença de margens plicadas essa descrição discorda de todos materiais examinados.

5. Neea pubescens Poepp. \& Endl., Nov. Gen. sp. pl. 2: 46. 1838. Tipo: Brasil, "in fruticetis circum oppidum Ega Brasiliae borealis".

Poeppig \& Endlicher (1838) diferenciam esta espécie das demais do gênero pela pubescência curtíssima mas densa e macia na face inferior da folha. Por este caráter, parece ser semelhante a $N$. hermaphrodita, mas a curta descrição indica ainda panícula pequena igualando a metade da folha, o que raramente ocorre nesta última. Não há medidas na descrição original. Caso seja localizado o tipo e se comprovar ser conspecífico com $N$. hermaphrodita, o nome $N$. pubescens deverá prevalecer por ser anterior. A descrição desta espécie na Flora Brasiliensis por Schmidt (1878), baseada apenas no material-tipo, concorda com a de $N$. hermaphrodita, porém menciona inflorescência incompleta.

6. Neea pulcherrima Heimerl, Denkschr. Akad. Wiss., Wien, Math.-nat. 79: 237. 1908. Tipo: Brasil, São Paulo, "in silvis prope Alto da Serra, 900 m s.m., maio/1901", Wettstein \& Schiffner s.n.

Não foi localizado o espécime-tipo desta espécie; contudo, pela descrição, exceto pela inflorescência, parece tratar-se de N. pendulina, descrita dois anos antes (Heimerl 1906). Segundo o autor, a espécie N. pulcherrima seria distinta pelos ramos divaricados, glabrescentes, folhas cuspidadas e glabras, inflorescência com ramos decussados e perianto com apenas 6 estames. Todos os materiais estudados de $N$. pendulina entretanto apresentam inflorescência com ramos verticilados.

7. Neea tristis Heimerl, Notizbl. Bot. Gart. Mus. Berl. 6: 128. 1914. Tipo: Brasil, "Estado de Amazonas, Jurua Mero, flor. Septemb. 1901", Ule n. B. 62.

Pela data da coleta e pela numeração de Ule em outros materiais estudados, o espécime-tipo não parece ser "n. B. 62" mas algo entre 5704 e 5855, talvez Ule 5762. De qualquer forma não foi localizado este material. Foram vistos alguns materiais determinados em herbários por Standley como N. tristis (Krukoff 8158, 8303, 5878,6058 ) mas pertencem a N. oppositifolia. É possível que N. tristis seja conspecífica com N. oppositifolia, pois Heimerl (1914) indica-a como próxima de $N$. rosea, sinonimizada aqui em $N$. oppositifolia, diferenciandoa pelas nervuras pouco salientes e cálice pouco mais oval. 
8. Neea virens Poepp.ex Heimerl, Jber. StOberrealsch. 23: 38. 1897. Tipo: "Peruvia subandina, Cuchero", Poeppig 1330.

Esta espécie foi descrita com material do Peru, mas Standley (1937a) informa que $N$. virens ocorreria também no Brasil. Este autor cita uma foto do material-tipo depositado no herbário de Berlim. A espécie seria caracterizada pelas folhas alternas grandes, oblongo-elípticas a oblongo-obovadas, verdes quando secas e inflorescência com pedúnculo curto até $2,5 \mathrm{~cm}$ compr. A única espécie de Neea estudada com folhas verdes quando secas e oblongo-elípticas a oblongo-obovadas é $N$. laxa, porém esta possui folhas opostas e inflorescência laxa e longo-pedunculada. É possível que $N$. virens seja uma variação de $N$. laxa devido aos poucos materiais estudados desta última. Deve-se ressaltar que nos gêneros da tribo Pisonieae a ocorrência de folhas alternas é excepcional em alguns ramos muito alongados.

9. Pisonia cafferiana Casar., Nov. Stirp. Bras. decas 8: 68. 1844. Tipo: Brasil, "in silvis montis Corcovado, pr.civitas Rio de Janeiro", Casaretto s.n.

Na descrição desta espécie não há menção a flores ou frutos. Talvez possa ser incluída em Guapira obtusata pelas folhas obovadas a oblongas, de base e ápice pouco obtusos. Choisy (1849) cita Pisonia cafferiana como sinônimo de P. nigricans var. oblonga, aqui sinonimizada em G. obtusata. O material Blanchet 3596, citado por Schmidt (1872) como P. cafferiana, pertence a G. obtusata. Provavelmente o material-tipo esteja depositado no herbário de Turim (TO), não visitado.

10. Pisonia crenulata J.A. Schmidt in Mart., FI. Bras. 14(2): 356. 1872. Tipo: "in Brasília meridionali", Sellow s.n.

Não foi localizado o tipo desta espécie, que é bastante impreciso. A descrição foi baseada apenas neste material sem flores mas com frutos. Segundo Schmidt (1872) as folhas seriam oblongo-lanceoladas com margens notavelmente crenuladas e o antocarpo seria estriado-costado com costas pouco salientes e sutilmente crenuladas. Folhas crenuladas ocorrem apenas em alguns exemplares de Guapira campestris, que apresenta folhas em geral de base cordada e antocarpos lisos. A descrição do antocarpo de $P$. crenulata entretanto, com costas sutilmente crenuladas, parece referir-se aos antocarpos glandulosos do gênero Pisonia, gênero em que foi descrita, e não de Guapira.

11. Pisonia elliptica J.A.Schmidt in Mart., FI. Bras. 14(2): 361. 1872. Tipo: Brasil, "inter Campos et Victoria", Sellow n. 228 \& Sellow n. 305.

Os sintipos referidos não foram localizados. A descrição de $P$. elliptica com folhas elípticas, sésseis de base arredondada, às vezes "semiamplexicaulia", indica que pode tratar-se de Guapira pernambucensis ou de G. campestris. Heimerl (1897) não examinou os materiais-tipo mas sinonimizou $P$. elliptica em $P$. pernambucensis.

12. Pisonia florida Choisy in DC., Prodr. 13(2): 443. 1849. Tipo: Brasil, "in Brasília ad S.Catherinam", masc., Bacle s.n.

A descrição original foi baseada em um único material estaminado, não localizado. Segundo Choisy (1849), $P$. florida seria espécie próxima de $P$. minor, aqui sinonimizada em Guapira opposita, diferenciando-se pela forma ovada da folha. Reitz (1970) incluiu P. florida como sinônimo de G. opposita, baseado na descrição, pois não há citação do material-tipo entre os materiais examinados. Entretanto Choisy (1849) refere bractéolas formando invólucro persistente, um caráter que não ocorre em G. opposita.

13. Pisonia laurifolia J.A. Schmidt in Mart., FI. Bras. 14(2): 364. 1872. Tipo: Brasil, "in fruticetis humidis ad Rio S. João (prov.?)", Riedel 1324.

$P$. laurifolia foi descrita por Schmidt (1872) como espécie a ser estudada posteriormente por dispor apenas de um exemplar incompleto. Segundo Heimerl (1897) esta espécie seria semelhante a $P$. riedeliana, aqui sinonimizada em G. laxa. Pode ser que Schmidt (1872) tenha se baseado num exemplar glabro, depois ele menciona folhas secas verde-pardas, brilhantes na face superior e ferrugíneas, opacas na face inferior, caracteres que ocorrem às vezes em $G$. laxa.

14. Pisonia palicureoides Casar., Nov. Stirp. Bras. decas 8: 68. 1844. Tipo: Brasil, "in montis Corcovado, Cravea, Babylonia pr. civitas Rio de Janeiro", Casaretto s.n., "Syn: Bessera calycantha Vell.".

Não foi visto o espécime-tipo deste binômio. Não há descrição das flores mas o "fruto" liso e negro indica tratar-se de representante de Guapira ou Neea, mais provavelmente Guapira devido ao fato de Casaretto (1844) citar Bessera calycantha, um nome anterior, como sinonímia de sua espécie. Choisy (1849) e Schmidt (1872) incluem P. palicureoides como sinônimo em P. olfersiana. Provavelmente P. palicureoides pertença a Guapira opposita. 
15. Torrubia snethlagei Standl., Field. Mus. Nat. Hist. Bot. 11(5): 153. 1936. Tipo: Brasil, "Maranhão, São Luiz, praia do olho d'água", 31.VII.1923, H. Snethlage 152 (Type in F, dupl. in B)".

T. snethlagei seria caracterizada pela folha subséssil, arredondada a oval ou elíptica-arredondada. Entre as espécies estudadas de Guapira com este tipo de folha, destacam-se G. pernambucensis e G. campestris. A descrição da inflorescência como cimosa de base tricotômica, com poucas flores, e ramos ferrugíneo-vilosos a quase glabros, bem como a descrição das flores estaminadas com $2 \mathrm{~mm}$ largura, parecem indicar que se trata de G. campestris. Todavia esta é uma espécie de cerrado, enquanto que G. pernambucensis ocorre frequentemente próximo a praias. Não foi visto o espécime-tipo.

Lista de espécies e variedades sinonimizadas neste trabalho:

1. Columella rustica Vell. = Guapira opposita Vell.

2. Neea aeruginosa Standl. $=$ N. madeirana Standl.

3. . . bangii Rusby $=N$. hermaphrodita $S$. Moore

4. N. compressa J.A. Schmidt $=N$. oppositifolia Ruiz \& Pav.

5. N. constricta Spruce ex J.A. Schmidt = N. macrophylla Poepp. \& Endl.

6. N. glaziovii Heimerl ex Glaziou $=$ N. verticillata Ruiz \& Pav.

7. N. glomeruliflora Heimerl $=N$. ovalifolia Spruce ex J.A. Schmidt

8. N. glomeruliflora var. coniungens Heimerl $=N$. ovalifolia Spruce ex J.A. Schmidt

9. . krukovii Standl. = N.madeirana Standl.

10. N. lanceolata Choisy = Guapira opposita (Vell.) Reitz

11. N. mollis Spruce ex J.A. Schmidt = N. parviflora Poepp. \& Endl.

12. $N$. paraensis Huber $=N$. parviflora Poepp. \& Endl.

13. N. pectinata Rizzini $=$ N. theifera Oerst.

14. N. rosea Mart. ex J.A. Schmidt $=N$. oppositifolia Ruiz \& Pav.

15. N. rufula Mart. ex J.A. Schmidt $=$ N. laxa Poepp. \& Endl.

16. N. schwackeana Heimerl = N. pendulina Heimerl

17. $N$. selloiana Heimerl = N. hermaphrodita S.Moore

18.N. sparsiflora Heimerl = N. ovalifolia Spruce ex J.A.Schmidt

19. N. spruceana Heimerl $=$ N. oppositifolia Ruiz \& Pav.

20. $N$. subpubescens Heimerl $=N$. hermaphrodita S.Moore

21. Pisonia aculeata var. guaranitica Chodat $=P$. aculeata $L$.

22. $P$. aculeata var. hirsutissima J.A. Schmidt $=P$. ambigua Heimerl

23. $P$. acuminata Mart.ex J.A. Schmidt $=$ Guapira nitida (Mart.ex J.A. Schmidt) Lundell

24. $P$. breviflora Huber $=$ Neea obovata Spruce ex Heimerl

25. $P$. cacerensis Hoehne $=$ Guapira areolata $($ Heimerl) Lundell

26. $P$. campestris var. glaucescens Mart. ex J.A. Schmidt $=$ G. campestris. (Netto) Lundell

27. P. campestris var. myrtifrons Mart.ex J.A. Schmidt $=$ G. campestris (Netto) Lundell

28. P. combretiflora Mart. ex J.A. Schmidt = G. obtusata (Jacq.) Little

29. $P$. comosa Choisy $=$ G. opposita (Vell.) Reitz

30. P. cordifolia Mart.ex J.A. Schmidt $=$ G. pernambucensis (Casar.) Lundell

31. $P$. darwinii Hemsley = G. laxa (Netto) Furlan

32. $P$. graciliflora var. subferruginosa Mart.ex J.A. Schmidt $=$ G. opposita (Vell.) Reitz

33. $P$. heterophylla Choisy $=$ G. opposita (Vell.) Reitz

34. P. humilis Glaziou $=$ G. campestris (Netto) Lundell

35. P. laxiflora Choisy $=$ G. opposita (Vell.) Reitz

36. P. loranthoides H.B.K. = Pisonia aculeata L.

37. $P$. luteovirens Heimerl = Guapira areolata $($ Heimerl) Lundell

38. P. minor Choisy = G. opposita (Vell.) Reitz

39. $P$. nigricans var.oblonga $=$ G. obtusata (Jacq.) Little

40. P. nitida var. parvifolia J.A. Schmidt $=$ G. nitida (Mart. ex J.A. Schmidt) Lundell

41. P. obtusata var. rufescens J.A. Schmidt $=G$. noxia (Netto) Lundell

42. $P$. obtusiloba Huber = G. opposita (Vell.) Reitz

43. $P$. paraguayensis Heimerl $=G$. areolata (Heimerl) Lundell

44. $P$. pernambucensis var. cordata Heimerl = G. pernambucensis (Casar.) Lundell

45. P. platystemon Heimerl = G. laxa (Netto) Furlan

46. $P$. psamophila Mart. ex J.A. Schmidt = G. laxa (Netto) Furlan

47. $P$. riedeliana Fischer ex Heimerl $=G$. laxa (Netto) Furlan 
48. $P$. stellulata Huber $=$ Neea ovalifolia Spruce ex J.A. Schmidt 49. $P$. subcapitata Huber $=N$. ovalifolia Spruce ex J.A. Schmidt 50. P. subcapitata var. laxiuscula Huber $=N$. ovalifoha Spruce ex J.A. Schmidt

51. $P$. warmingii Heimerl = Guapira hirsuta (Choisy) Lundell

52. Pisoniella apolinarii M.Lisboa = Guapira opposita (Vell.) Reitz

53. Torrubia asperula Standl. = Guapira hirsuta (Choisy) Lundell

54. T. hoehnei Standl. = G. nitida (Mart. ex J.A.Schmidt) Lundell

55. $T$. loefgrenii Standl. = G. pernambucensis (Casar.) Lundell

56. $T$. parvifolia Standl. = G. opposita (Vell.) Reitz

\section{Agradecimentos}

Os autores agradecem às pessoas e instituições que colaboraram para a execução desse trabalho, sobretudo os curadores e técnicos dos herbários citados; à Emiko Naruto (in memoriam) pelas ilustrações. A segunda autora agradece ao Norberto Palácios pela digitalização do texto original e organização da lista de exsicatas e ao Dr. José Rubens Pirani pela ajuda na adequação do trabalho de tese ao formato de manuscrito, pois sem a ajuda deles jamais esse trabalho seria publicado.

\section{Referências}

ADAMS, C.D. 1970. Notes on Jámaican Flowering Plants $\mathrm{H}$. Nomenclatural changes and additions in Nyctaginaceae. Mitt. hot. Stsaml. Munchen 8: 111121.

ALAIN, H. 1960. Novedades en la flora cubana, XII. Candollea 17: 113-114.

APG III (Angiosperm Phylogenetic Group). 2009. An update of the Angiosperm Phylogeny Group classification for the orders and families of flowering plants. Botanical Journal of the Linnean Society 161: 105-121.

AUBLET, M.F. 1775. Histoire des plantes de la Guiane Francoise. Didot, Paris. 3 vols.

BAILLON, H. 1875. The natural history of plants, vol. 3. L. Reeve \& Co., London.

BAKER, H.G. 1964. Variation in style length in relation to outbreeding in Mirabilis (Nyctaginaceae). Evolution 18(3): 507-509.

BARROSO, G.M. 1978. Sistemática de Angiospermas do Brasil, vol. 1. Ed. LTC/Edusp.

BARTH, O.M. \& BARBOSA, A.F. 1972. Catálogo sistemático dos pólens das plantas arbóreas do Brasil Meridional. XIV - Nyctaginaceae e Phytolaccaceae. Mem. Inst. Oswaldo Cruz 70(3): 241-259.

BATEMAN, A.J. 1968. The role of heterostylly in Narcissus and Mirabilis. Evolution 22(3): 645-646.
BEIGUELMAN, B. 1962. Fibras do periciclo ramificadas no interior do mesofilo. Phyton 18(2): 127-131.

BEHNKE, H.-D. 1972. Sieve-tube plastids in relation to angiosperm systematics - an attempt towards a classification by ultrastructural analysis. Bot. Rev. 38(1): 155-197.

BEHNKE, H.-D. 1976. Ultrastructure of sieve-elemente plastids in Caryophyllales (Centrospermae), evidence for the delimitation and classification of the Order. Plant Syst. Evol. 126: 31-54.

BEHNKE, H.-D. 1977. Transmission electron microscopy and systematics of Flowering Plants. Plant Syst. Evol., Suppl. 1: 155-178.

BENTHAM, G. \& HOOKER, J.D. 1880. Genera Plantarum vol. 3 L. Reeve \& Co./ Willians \& Norgate, London.

BITTRICH, V. \& KÜHN, U. 1993. Nyctaginaceae. In K. Kubitzki, J.G. Rohwer \& V. Bittrich (eds.). The families and genera of flowering plants, vol. 2. Springer. Berlin, p. 473-486.

BOGLE, A.L. 1974. The genera of Nyctaginaceae in the Southeastem United States. J. Arnold Arb. 55(1): 1-37.

BOHLIN, J.-E. 1984. Taxonomical investigations in the Nyctaginaceae in NW South America. Scandinavian Research in Ecuador. Rep. Bot. Inst. Univ. Aarhus 9: 20-21.

BORGMEIER, T. 1961. A historia da "Flora Fluminensis" de Frei Vellozo. Publ. Arq. Nacional 48: 1-21.

BRITTON, N.L. 1900. Nyctaginaceae. In H. H. Rusby, An enumeration of the plants collected by Dr. H. H. Rusby in South América, 1885-1886. Bull. Torrey Bot. Club 27: 124-127.

BRITTON, N.L. 1904. On Pisonia obtusata and its allies. Bull. Torrey Bot. Club 31: 611-615.

BRITTON, N.-L. 1918. Flora of Bermuda (Facsimile 1965). Hafner Publ. Co., New York.

BRITTON, N.-L. \& MILLSPAUGH, C.F. 1920. The Bahama Flora (ed. 1962). Hafner Publ. Co., NewYork. 
BROWN, A.D., CHALUKIAN, S.C. \& MALMIERCA, L.M. 1985. Estudio floristicoestructural de un sector de selva semidecidua del noroeste argentino. I. Composicion floristica, densidad y diversidad. Darwiniana 26(1-4): 27-41.

BURGER, W. 1983. Nyctaginaceae. In W. Burger, Flora Costaricensis. Fieldiana Bot. 13: 180-199.

CAMINHOA, J.M. 1877. Elementos de Botânica Geral e Médica. vol 2. Ed. Typografia Nacional, Rio de Janeiro.

CARAUTA, J.P.P. 1969. A data efetiva de publicação da "Flora Fluminensis". Vellozia 7: 26-33.

CARAUTA, J.P.P. 1973. The text of Vellozo's Flora Fluminensis and its effective date of publication. Taxon 22(2/3): 281-284.

CASARETTO, J. 1844. Novarum Stirpium Brasiliensium, Decades 8. Typis Joanis Ferrandi, Genova.

CHODAT, R. \& REHFOUS, L. 1926. La vegetation du Paraguay. Bull. Soc. Bot. Geneve 17: 127-164.

CHOISY, J.D. 1849. Nyctaginaceae. In A.P. De Candolle (ed.) Prodromus Systematis Naturalis Regni Vegetabilis. Treuttel \& Würtz. Paris, vol. 13, pars 2, p. 425-458.

COCUCCI, A.E. 1980. Precisiones sobre la terminologia sexologica aplicada a angiospermas. Bol. Soc. Argent. Bot. 19(1-2): 75-81.

CORNER, E.J.H. 1976. The seeds of dicotyledons. 2 vols. Cambridge University Press. Cambridge.

CRONQUIST, A. 1968. The evolution and classification of flowering plants. Houghton Mifflin. Boston.

CRONQUIST, A. 1981. An integrated system of classification of flowering plants. Columbia University Press. New York.

CRONQUIST, A. 1988. The evolution and classification of flowering plants. Ed. 2. The New York Botanical Garden. New York.

DAHLGREN, R. 1977. A commentary on a diagrammatic presentation of the angiosperms in relation to the distribution of character states. Plant Syst. Evol., Suppl. 1: 253-283.

DAHLGREN, R. 1980. A revised system of classification of the angiosperms. Bot. J. Linn. Soc. 80: 91-124.

D'ARCY, W.G. 1970. Jácquin names, some notes on their typification. Taxon 19(4): 554-560.

DIAZ, M.A. \& ESQUIVEL, M.A. 1983. Contribuciones al estudio de Pisonia rotundata Griseb. s.l. (Nyctaginaceae) em Cuba. I-Estudio de las poblaciones cubanas. Revta Jard. Bot. Nacional 4(3): 35-50.
DOUGLAS, N.A. \& MANOS, P.S. 2007. Molecular phylogeny of Nyctaginaceae: taxonomy, biogeography, and characters associated with a radiation of xerophytic genera in North America. Amer. J. Bot. 94(5): 856-872.

DOUGLAS, N.A. \& SPELLENBERG, R. 2010. Tribal classification of Nyctaginaceae. Taxon 59(3): 905910.

DUCKE, A. 1959. Estudos botânicos no Ceará. Anais Acad. Bras. Ciênc. 31(2): 211-308.

DUMAS, M.A.D. 1988. Sobre la verdadera identidad de Pisonia aculeata L. (Nyctaginaceae). Lectotipificacion. Revta J. Bot. Nacional 9(1): 9-13.

DUMAS, M.A.D. 1990. Evidencias para la reconsideracion de los limites genéricos in la Tribu Pisonieae (Nyctaginaceae). Resumenes, $V$ Congreso Latinoamericano de Botánica, Habana, p. 251.

ECKARDT, T. 1964. Reihe Centrospermae. In H. Melchior (ed.) A. Engler's Syllabus der Pflanzenfamilien, vol. 2, Ed. 12. Gebrüder Borntraeger. Berlin, p. 79-101.

ECKARDT, T. 1976. Classical morphological features of centrospermous families. Plant Syst. Evol. 126: 5-25.

EHRENDORFER, F. 1976a. Chromosome numbers and differentiation of centrospermous families. Plant Syst. Evol. 126: 27-30.

EHRENDORFER, F. 1976b. Closing remarks: systematics and evolution of centrospermous families. Plant Syst. Evol. 126: 99-105.

FARIA, G.M. 1994. A flora e a fauna apícola de um ecossistema de campo rupestre, Serra do Cipó, MG, Brasil: composição, fenologia e suas interações. Tese de Doutorado, UNESP. Rio Claro.

FAWCET, W. \& RENDLE, A.B. 1914. Nyctaginaceae. Flora of Jamaica 3: 145-154.

FIEDLER, H. 1910. Beitrage zur Kenntnis der Nyctaginiaceen. Bot. Jahrb. 44: 572-605.

GALLOWAY, L.A. 1975. Systematics of the North American Desert Species of Abronia and Tripterocalyx (Nyctaginaceae). Brittonia 27: 328347.

GENTRY, A.H. 1993. A field guide to the families and genera of woody plants of Northwest South America (Colômbia, Ecuador, Peru). Conservation Intemational. Washington, DC.

GLAZIOU, A.-F.-M. 1911. Liste des Plantes du Brasil Central. Nyctaginees. Bull. Soc. Bot. Fr., 58, 4. ser., 11, Mem, 3 : :560- 563.

GODOY, V.M. 1976. Nova fonte de amido. 28a Reunião da Sociedade Brasileira para o Progresso da Ciência, SBPC. Brasília (separata) 38 p. 
GRANVILLE, J. J. 1992. Un cas de distribution particulier: les especes forestieres periamazoniennes. Comptes Rendus Seanc. Soc. Biogeogr. 68(1): 1-33.

GREUTER, W., BARRIE, F.R., BURDET, H.M., CHALONER, W.G., DEMOULIN, V., HAWKSWORTH, D.L., JORGENSEN, P.M., NICHOLSON, D.H., SILVA, P.C., TREHANE, P., \& Mc NEILL, J. 1994. International Code of Botanical Nomenclature. Regnum Vegetabile vol. 131. Koeltz Scient. Book. Koningstein.

GRISEBACH, A. 1878. Symbolae ad Floram Argentinam. Dieterich'sche Verlag Buchhandlung. Gottingen.

HEIMERL, A. 1891. Nyctaginiaceae in E. Warming (ed.) Symbolae ad floram Brasiliae centralis. Vidensk. Meddr. dansk naturh. Foren 1890: 158163.

HEIMERL, A. 1896. Nyctaginaceae in I. Urban (ed.) Additamenta ad cognitionen florae Indiae Occidentalis, III. Bot. Jahrb. 21: 615-638.

HEIMERL, A. 1897. Beitrage zur Systematik der Nyctaginaceen. Jber. StOberrealsch., Wien, 23.

HEIMERL, A. 1901. Nyctaginaceen der Herbarium Delessert. Ann. Conserv. Jard. bot. Genève 5: 177197.

HEIMERL, A. 1906a. Beitrage zur Kenntnis Amerikanischer Nyctaginaceen. Ost. Bot. Z. 56(7): 249-255.

HEIMERL, A. 1906b. Beitrage zur Kenntnis Amerikanischer Nyctaginaceen. Ost. Bot. Z. 56(10): 406-414.

HEIMERL, A. 1906c. Beitrage zur Kenntnis Amerikanischer Nyctaginaceen. Ost. Bot. $Z$. 56(12): 424-429.

HEIMERL, A. 1908. Pisonia ambigua n. sp. Denkschr. Akad. Wiss., Wien, Math.-nat. 79: 236-237.

HEIMERL, A. 1909. Nyctaginaceae austroamericanae. In I. Urban (ed.) Plantae novae andinae imprimis Weberbauerianae IV. Bot. Jahrb. 42: 73-81.

HEIMERL, A. 1911. Pisoniella, eine neue Gattung der Nyctagginaceen. Ost. Bot. Z. 61: 462-471.

HEIMERL, A. 1912. Die Nyctaginaceen and Phytolaccaceen des Herbarium Hassler. Verh. Zool. -Bot. Ges. Wien 62: 1-17.

HEIMERL, A. 1913. Herzog's bolivianische Pflanzen I. Meded Rijks-Herb., Leiden: 33- 35.

HEIMERL, A. 1914. Nyctaginaceae. In R. Pilger (ed.) Plantae uleanane novae vel minus cognitae. Notizbl. Bot. Gart. Mus. Berlin 6: 126-132.

HEIMERL, A. 1921. Nyctaginaceae novae. In F. Fedde (ed.) Repert. nov. Spec. Regni veg. 17(474/476): 13.
HEIMERL, A. 1932. Nyctaginaceen-Studien. Notizbl. Bot. Gart. Mus. Berlin 11: 450-470.

HEIMERL, A. 1934. Nyctaginaceae. In A. Engler, K. Prantl \& H. Harms (eds.) Die natiirlichen Pflanzenfamilien. Wilhem Engelmann. Leipzig, Band 16 C, p. 86-134.

HERNANDEZ, H.M. 1990. Autopolinizacion en Mirabilis longiflora L. (Nyctaginaceae). Acta Bot. Mexicana 12: 25-30.

HESS, R.W. 1946. Identification of New World Timbers, part II. Tropical Woods 87: 11-36.

HICKEY, L.J. 1973. Classification of the architecture of dicotyledonous leaves. Am. J. Bot. 60(1): 17-33.

HOEHNE, F.C. 1915. Pisonia cacerensis Hoehne (sp. nov.) ex set. inermes. Comissão de Linhas Telegraphicas Estrategicas de Matto-Grosso ao Amazonas, Anexo 5(5): 70-71, tab. 109.

HOLMGREN, P.K., HOLMGREN, N.H. \& BARNETT, L.C. 1990. Index Herbariorum. Part 1: The Herbaria of the World. Ed. 8. International Association for Plant Taxonomy. New York Botanical Garden. NewYork.

HOWARD, R.A. 1983. The plate of Aublet's Histoire des Plantes de la Guiane Françoise. J. Arnold Arb. 64: 255-292.

HUBER, J. 1909. Materiaes para a flora amazônica VII. Plantae Duckeanae austroguyanenses. Bol. Mus. Paraense Emilio Goeldi, Bot. 5(2): 294-352.

HUEBER, F.M., NAMBUDIRI, E.M.V., TIDWELL, W.D. \& WHEELER, E.F. 1991. An Eocene fóssil tree with cambial variant wood structure. Review Palaeobot. Palynol. 68: 257-267.

HUMBOLDT, A., BONPLAND, A. \& KUNTH, C.S. 1817. Nova genera et species plantarum. Librariae Graeco-Latino-Germanicae. Paris, vol. 2, p. 171177.

HUMBOLDT, A., BONPLAND, A. \& KUNTH, C.S. 1825. Nova genera et species plantarum. Librariae Graeco-Latino-Genninicae. Paris, vol. 7, p. 153.

IBGE. 1972. Carta do Brasil ao milionésimo. Dep. Doc. e Div. Geográfica e Cartografica. Brasília, 46 mapas.

JACKSON, D. 1895. Index Kewensis Plantarum Phanerogamarum, vol. 1. Claredon Press. Oxford.

JACQUIN, N.J. 1763. Selectarum Stirpium Americanarum Historia. Officina Krausina. Vindobone.

JACQUIN, N.J. 1798. Plantarum rariorum horti caesari schoenbrunnensis, vol. 3. C.F. Wappler. Vienna.

JIMBO, S. 1962. A flora na alimentação das aves brasileiras. Instituto de Botânica de São Paulo. São Paulo. 
JUSSIEU, A.L. 1803. Observations sur la famille des plantes nyctaginées. Ann. Mus. Hist. Nat. Paris 2: 269-279.

KENDRICK, R.E. \& HILLMAN, W.S. 1971. Absence of phytochrome dark reversion in seedlings of the Centrospermae. Am. J. Bot. 58(5): 424-428.

KUNTH, C.S. 1832. Ober eine neue Gattung aus der Familie der Nyctagineen. Vier. Bot. Abh.: 208-210.

LIESNER, R.L. 1993. Nyctaginaceae. In L. Brako \& J.L. Zarucchi (eds.) Catalogue of the flowering plants and gymnosperms of Peru. Missouri Botanical Garden. Saint Louis, p. 750-754.

LINK, J.H.F., OTTO, C.F. \& KLOTZSCH, J.F. 1841. Pisonia olfersiana. Icons Plantarum rariorum horti regii botanici berolinensis 1: 36-38, tab. 15.

LINNAEUS, C. 1753. Species Plantarum, vol. 1. Facsimile Ed. The Ray Society. London.

LISBOA, M.A. 1974. Duas novas espécies de Nyctaginaceae. Escola de Minas e Metalurgia da Universidade Federal de Ouro Preto.

LITTLE Jr. E.L. 1964. (149) Proposal to conserve the generic name (2354) Torrubia Vell. (1825) against Guapira Aublet (1775), Gynastrum Neck (1790), Bessera Vell (1825) and Columella Vell. (1825) (all of Nyctaginaceae). Regnum veg. 34: 58-59.

LITTLE Jr., E.L. 1968. Transfers to Guapira from Torrubia (Nyctaginaceae). Phytologia 17(5): 367368.

LUNDELL, C.L. 1962. Plantae Mayanae V. Wrightia 3(2): 21-35.

LUNDELL, C.L. 1968. Studies of tropical American Plants V. Wrightia 4(2): 79-96.

MAAS, P.J.M. \& WESTRA, L.Y.Th. 1993. Neotropical plant families. Koeltz Scientific Books. Germany.

MABRY, T.J. 1976. Pigment dichotomy and DNA-RNA hybridization data for centrospermous families. Plant Syst. Evol. 126: 79-94.

McVAUGH, R. 1968. Report of the Committee for Spermatophyta. Taxon 17(4): 462-466.

MEISNER, C.F. 1841. Plantarum vasculariarum Genera. Libraria Weidmania. Lipsiae, pars I. Tab.diag.: 318. pars II. Comentarius: 230.

METCALFE, C.R. \& CHALK, L. 1950. Anatomy of the dicotyledons. vol. 1. Claredon Press.

METCALFE, C.R. \& CHALK, L. 1988. Anatomy of the dicotyledons. vol.I e II. Ed. 2. Oxford Science Publications. Oxford.

MIRANDA, F. 1950. Algunas novedades de la Flora de Chiapas. An. Inst. Biol. Univ. Mex. 21(2): 299-308.

MOORE, S. M. 1895. Neea hermaphrodita sp. nov. Trans. Linn. Soc. Lond Bot. ser. II, 4: 442, pl. 28.
MORI, S.A., BOOM, B.M., CARVALHO, A.M. \& SANTOS, T.S. 1983 Southeem Bahian Moist Forests. Bot. Rev. 49(2): 155-232.

NETTO, M.L. 1866a. Addition a la Flore du Brésil. Ann. Sci. nat., ser. 5, Bot. 5: 80-87, tab. 7, 8.

NETTO, L. 1866b. Itineraire Botanique dans la Province de Minas Gerais. Simon Raton et Cie., p: 4-21.

NORONHA, A.B.; GIL, V.L. \& VICENTE, M. 1980. Occurence of plant virus inhibitors in species of Caryophyllales.I. Arq. Inst. Biol. Silo Paulo 47(3): 71-76.

NOWICKE, J.W. 1970. Pollen morphology in the Nyctaginaceae. I. Nyctagineae (Mirabileae). Grana 10(2): 79-88.

NOWICKE, J.W. \& LUIKART, T.J. 1971. Pollen morphology of the Nyctaginaceae. II. Colignonieae, Boldoeae, and Leucastereae. Grana 11(3): 145150.

NOWICKE, J.W. \& SKVARLA, J.J. 1977. Pollen morphology and the relationship of the Plumbaginaceae, Polygonaceae and Primulaceae to the Order Centrospermae. Smithsonian Contrib. Bot: 1-64.

OERSTED, A.S. 1863. Neea theifera. avers. K danske Vidensk. Selsk. Forh. 1863: 9-10, pl. 1.

OERSTED, A.S. 1866. Til Belysning af Blomsterne hos den brasilianske Thebusk (Neea theifera Örd. 1863 = Pisonia caparrosa Netto 1866) og hos Sneklokkebusken (Halesia tetraptera L.). Särsk. nat. Foren. Vidensk. Meddel 1866(1-6): 89-96.

OERSTED, A.S. 1869. Zur Beleuchtung der Blumen des brasilianischen Theestrauches (Neea theifera Ord. 1863 = Pisonia caparrosa Netto 1866) und des Schneeglockchenstrauches (Halesia tetraptera L.). Bot. Ztg 14: 217-222.

PAGANO, S.N. \& LEITÃO F., H.F. 1987. Composição floristica do estrato arbóreo de mata mesófila semidecídua no município de Rio Claro (Estado de S. Paulo). Revista Brasil. Bot. 10: 37-47.

PARODI, D. 1878. Contribuciones á la Flora del Paraguay. Pablo E. Coni. Buenos Aires, p. 59-64.

PARODI, D. 1882. Apuntes sobre la familia de las Nictagíneas. An. Soc. Cient. Argent.14: 255-270.

PHILIPSON, W.R. 1977. Ovular morphology and the classification of dicotyledons. Plant Syst. Evol., Suppl. 1: 123-140.

PIGNAL, M., SOARES FILHO, A.O. \& ROMANIUC Neto, S. 2013. Une nouvelle espèce de Neea Ruiz \& Pav. (Nyctaginaceae) de la forêt atlantique de l'état de Bahia (Brésil). Adansonia 35(1): 19-31.

PIRES, J.M. 1981. Notas de Herbario I. Bol. Mus. Paraense Emilio Goeldi, n. ser., Bot. 52: 1-5. 
POEPPIG, E. \& ENDLICHER, S. 1838. Nova genera ac Species Plantarum. vol. 2. Friderici Hofmeister. Lipsiae.

PORTO, P.C. 1936. Plantas indígenas e exóticas provenientes da Amazônia, cultivadas no Jardim Botânico do Rio de Janeiro. Rodriguésia 2(5): 93157.

PRANCE, G.T. \& CAMPBELL, D.G. 1988. The present state of tropical floristics. Taxon 37(3): 519-548.

PUGLIA, M.P. \& NORVERTO, C.A. 1990. Estructura y ontogenia del leño anômalo de Pisonia zapallo Griseb. (Nyctaginaceae). Parodiana 6(2): 227-239.

RECORD, S.J. \& HESS, R.W. 1943. Timbers of the New World. Yale Univ. Press. New Haven.

REITZ, R. 1960. Nictagináceas catarinenses. Sellowia 12: 159-175.

REITZ, R..1970. Flora Ilustrada Catarinense. Nictagináceas. Herbário Barbosa Rodrigues. Itajaí.

REITZ, R., KLEIN, R.M. \& REIS, A. 1978. Madeiras do Brasil. Ed. Lunardelli. Florianópolis.

RHEEDE, H.A. 1688. Hortus indicus malabaricus. vol. 7. J. van Someren et J. van Dyck. Amstelodami.

RICKETT, H.W. 1955. Material for a dictionary of botanical terms-III. Inflorescences. Bull. Torrey Bot. Club 82(6): 419-445.

RIZZINI, C.T. 1975. Novitates Florae Brasiliensis. Leandra 5(6): 33-46.

RODMAN, J.E., OLIVER, M.K., NAKAMURA, R.R., McCLAMMER Jr., J.V. \& BLEDSOE, A.H. 1984. A taxonomic analysis and revised classification of Centrospermae. Syst. Bot. 9(3): 293-323.

RODMAN, J.E., OLIVER, M.K., NAKAMURA, R.R., McCLAMMER Jr., J.V. \& BLEDSOE, A.H. 1990. Centrospermae revisited, part I. Taxon 39(3): 383393.

RUIZ, H. \& PAVON, J.A. 1798. Systema Vegetabilium florae peruvianae et chilensis. Typis Gabrielis de Sancha. Madrid.

RUSBY, H.H. 1907. Neea bangii sp. nov. Bull.New York Bot. Gard. 4: 435.

SÁ, C.F.C. 2010. Nyctaginaceae. In: R.C. Forzza, J.F.A. Baumgratz, C.E.M. Bicudo, A.A. Carvalho Jr. A. Costa, D.P. Costa, M. Hopkins, P.M. Leitman, L.G. Lohmann, L.C. Maia, G. Martinelli, M. Menezes, M.P. Morim, M.A.N. Coelho, A.L. Peixoto, J.R. Pirani, J. Prado, L.Q. Queiroz, V.C. Souza, J.R. Stehmann, L.S. Sylvestre, B.M.T. Walter, \& D. Zappi, (eds.), Catálogo de Plantas e Fungos do Brasil. vol. 1 Instituto de Pesquisas Jardim Botânico do Rio de Janeiro, Rio de Janeiro, p. $1330-1331$.
SALGADO-LABORIAU, M.L., CARVALHO, L.D'A.F. \& CAVALCANTE, P.B. 1969. Pollen grains of plants of the "Cerrado". XXI-Ebenaceae, Nyctaginaceae, Rhamnaceae and Solanaceae. Bol. Mus. Paraense Emilio Goeldi, Bot 32: 1-12.

SALOMAO, R.P., SILVA, M.F.F. \& ROSA, N.A. 1988. Inventário ecológico em floresta pluvial tropical de terra firme, Serra Norte, Carajás, Pará. Bol. Mus. Paraense Emilio Goeldi, Bot. 4(1): 1-45.

SCHMIDT, J.A. 1872. Nyctagineae. In C.F.P. Martius \& A.G. Eichler (eds.) Flora brasiliensis. Fried. Fleischer. Munchen, vol. 14, pars 2, p. 345-376, tab. 81-88.

SHARMA, A.K. \& BHALTACHARYYA, U. 1961. Further investigation on the citology of some members of Nyctaginaceae. Indian Agriculturist 5(1): 9-28.

SHARMA, H.P. 1963. Contributions to the morphology of the Nyctaginaceae, II. Floral anatomy of some species. Proc. India Acad. Sci. Sect. B. 57(3): 149163.

SHAW, H.K.A. 1952. On the distribution of Pisonia grandis R.Br. Nyctaginaceae, with special reference to Malaysia. Kew Bull. 7: 87-97.

SILVA JR., M.C., FELFILI, J.M., PROENÇA, C.E.B., BRASILEIRO, A.C.M., MELLO FILHO, B., SILVA, P.E.N. \& COSTA, K.L. 1988. Fitossociologia da mata do morro da Quixaba no Território de Fernando de Noronha. Acta Bot. Bras. 3(2): 257362.

SILVESTRE, M.S.F. \& CARREIRA, S.M.S. 1985. Flora polínica da Reserva do Parque Estadual das Fontes do Ipiranga (São Paulo, Brasil), Famílias 23- Phytolaccaceae, 24-Nyctaginaceae e 27Caryophyllaceae. Hoehnea 12: 1-4.

SKVARLA, J.J. \& NOWICKE, J.W. 1976. Ultrastructure of pollen exine in Centrospermous families. Plant Syst. Evol. 126: 55-78.

SPICHIGER, R. \& DEFFERRARD, C. 1986. Proteáceas, Olacáceas, Opiliáceas y Nictagináceas del Arboretum Jenaro Herrera (Provincia de Requena, departamento de Loreto, Perú). Candollea 41(2): 473-492.

SPICHIGER, R., PABSE, R., CHAUTEMS, A. \& RAMELLA, L. 1995. Origin, affinities and diversity hot spots of the Paraguayan dendrofloras. Candollea 50(2): 515-537.

SPJUT, R.W. 1994. A systematic treatment of fruit types. Mem. New York Bot. Gard. 70: 1-182.

ST. JOHN, H. 1951. The distribution of "Pisonia grandis" (Nyctaginaceae). Pacific Plant Studies n. 10. Webbia 8: 225-228. 
STAFLEU, F.A. \& COWAN, R.S. 1976/1988. Taxonomic literature. 6 vols. Bohn, Scheltema \& Holkema. Utrecht.

STANDLEY, P.C. 1909. The Allioniaceae of the United States, with notes on Mexican species. Contr. U. S. Natn. Herb. 12(8): 303-389.

STANDLEY, P.C. 1911. The Allioniaceae of México and Central América. Contr. U. S. Natn. Herb. 13(11): 377-430.

STANDLEY, P.C. 1916. Studies of Tropical American Phanerogams n. 2, New or notable Allioniaceae. Contr. U.S. Natn. Herb. 18(3): 98-101.

STANDLEY, P.C. 1918. Allioniaceae. North American Flora 21(3): 171-254.

STANDLEY, P.C. 1922. Trees and shrubs of Mexico. Allioniaceae. Contr. U. S. Natn. Herb.23(2): 259262.

STANDLEY, P.C. 1929a. Studies of American Plants I, Nyctaginaceae. Field Mus. Nat. Hist. Bot. 4(8): 203-204.

STANDLEY, P.C. 1929b. Studies of American plants II, Nyctaginaceae. Field Mus. Nat. Hist. Bot. 4(8): 304-305.

STANDLEY, P.C. 1931a. Studies of American plants V, Nyctaginaceae. Field Mus. Nat. Hist. Bot. 8(5): 304-310.

STANDLEY, P.C. 1931b. The Nyctaginaceae of Northwestern South America. Field Mus. Nat. Hist. Bot. 11(3): 73-114.

STANDLEY, P.C. 1936. Studies of American plants VI. Nyctaginaceae. Field Mus. Nat. Hist. Bot. 11(5): 153-154.

STANDLEY, P.C. 1937a. Nyctaginaceae. In J.F. Macbride (ed.) Flora of Peru. Field Mus. Nat. Hist. Bot. 13(2): 518-546.

STANDLEY, P.C. 1937b. Studies of American plants VII. Nyctaginaceae. Field Mus. Nat. Hist. Bot. 17(2): 187-190.

STANDLEY, P.C. 1937c. Studies of American plants VIII. Nyctaginaceae. Field Mus. Nat. Hist. Bot 17(3): 241-244.

STANDLEY, P.C. 1937d. Flora of Costa Rica. Nyctaginaceae. Field Mus. Nat. Hist. Bot.18: 423426.

STANDLEY, P.C. 1939. Nyctaginaceae. In A.C. Smith (ed.) Notes on a Collection of Plants from British Guiana. Lloydia 2(3): 177 -178.

STANDLEY, P.C. 1940. Studies of American plants IX. Nyctaginaceae. Field Mus Nat. Hist. Bot. 22: 18-19.
STANDLEY, P.C. 1943. Nyctaginaceae. In R.E. Woodson Jr. \& R.E. Schery (eds.) Contributions toward a Flora of Panama VII. Ann. Missouri Bot. Gard. 30: 85-86.

STEMMERIK, J.F. 1964. Florae Malesianae Precursores XXXVIII. Notes on Pisonia L. in the Old World (Nyctaginaceae). Blumea 12(2): 275284.

STEYERMARK, J.A. 1987. Flora of the Venezuelan Guayana III. Ann. Missouri Bot. Gard. 74: 609-658.

STORNI, J.S. 1944. Hortus Guaranensis Flora. Univ. Nacional de Tucuman Publ. n. 354.

STUCKERT, T. \& HEIMERL, A. 1913. Die Nyctaginaceen Argentiniens. Annu. Comm. Járd. Bot. Genève 17: 220-234.

STUESSY, T.F. 1990. Plant taxonomy: the systematic evaluation of comparative data. Columbia University Press. New York.

TAKHTAJAN, A. 1980. Outline of the classification of flowering plants (Magnoliophyt a). Bot. Rev. 46(3): 225-359.

THIERS, B. [continuously updated]. Index Herbariorum: A global directory of public herbaria and associated staff. New York Botanical Garden's Virtual Herbarium. http://sweetgum.nybg.org/ih/

TOURSARKISSIAN, M. 1975. Las Nictagináceas argentinas. Revta Mus. Argent. Cienc. Nat. Bernardino Rivadavia Bot. 5(2): 27-83.

VELLOZO, J.M.C. 1825 (1829). Florae Fluminensis. Tipografia National, Rio de Janeiro, 352 p.; Icones T3 e T4, 1831.

WEBERLING, F. 1965. Typology of inflorescences. Bot. J. Linn. Soc. Bot. 59 (378): 215-221.

WEBERLING, F. 1988. The architecture of inflorescences in the Myrtales. Ann. Missouri. Bot. Gard. 75(1): 226-310.

WEBERLING, F. 1989. Morphology of flowers and inflorescences. Traduzido por R.J. Pankhurst. Cambridge University Press. Cambridge.

WOODCOCK, E.F. 1928. Seed studies in Nyctaginaceae. Pap. Mich. Acad. Sci. 9: 495-501.

WOODSON Jr., R.E. \& KIDD, H.J. 1961. Nyctaginaceae. In R.E. Woodson, R.W. Schery et al. (eds.) Flora of Panama. Ann. Missouri Bot. Gard. 48(4): 51-65.

WURDACK, J.J. 1970. Erroneous data in Glaziou collections of Melastomataceae. Taxon 19(6): 911 . 913 